\title{
Identification and functional characterization of cataract-specific gene expression changes reveals important pathways for human lens maintenance, aging and disease
}

John R. Hawse IV

West Virginia University

Follow this and additional works at: https://researchrepository.wvu.edu/etd

\section{Recommended Citation}

Hawse, John R. IV, "Identification and functional characterization of cataract-specific gene expression changes reveals important pathways for human lens maintenance, aging and disease" (2004). Graduate Theses, Dissertations, and Problem Reports. 2074.

https://researchrepository.wvu.edu/etd/2074

This Dissertation is protected by copyright and/or related rights. It has been brought to you by the The Research Repository @ WVU with permission from the rights-holder(s). You are free to use this Dissertation in any way that is permitted by the copyright and related rights legislation that applies to your use. For other uses you must obtain permission from the rights-holder(s) directly, unless additional rights are indicated by a Creative Commons license in the record and/ or on the work itself. This Dissertation has been accepted for inclusion in WVU Graduate Theses, Dissertations, and Problem Reports collection by an authorized administrator of The Research Repository @ WVU.

For more information, please contact researchrepository@mail.wvu.edu. 


\title{
Identification and functional characterization of cataract-specific gene expression changes reveals important pathways for human lens maintenance, aging and disease.
}

\author{
John R. Hawse IV
}

\author{
Dissertation \\ Submitted to the College of Arts and Sciences \\ at \\ West Virginia University \\ In Partial Fulfillment of the Requirements for the \\ Degree of Doctor of Philosophy \\ Marc Kantorow, Ph.D, Chair \\ Jonathan R. Cumming, Ph.D. \\ J. Fielding Hejtmancik, MD./Ph.D. \\ Ignacio R. Rodriguez, Ph.D. \\ Mark R. Walbridge, Ph.D.
}

Department of Biology

Morgantown, WV

2004 


\title{
ABSTRACT
}

\section{Identification and functional characterization of cataract-specific gene expression changes reveals important pathways for human lens maintenance, aging and disease.}

\begin{abstract}
John R. Hawse IV
Human age-related cataract, and opacity of the eye lens, is a multifactorial disease with a poorly understood etiology and is the leading cause of world blindness and low vision. It has been estimated that any therapy that could delay the onset of age-related cataract by ten years would halve the number of individuals requiring surgery in their lifetime. To accomplish such a feat, it is essential to understand the molecular mechanisms and biological pathways associated with this disease. Here, I describe the global gene expression profiles of human age-related cataracts compared to clear lenses, differentiate these changes from those that occur with aging of the human lens, cluster the identified genes to reveal functional pathways altered in this disease, characterize a family of proteins in lens epithelial cells that respond to the presence of toxic metals known to be associated with cataract formation and implicate an important role for the methionine sulfoxide reductase A enzyme in protecting lens cells against oxidative stress damage. The results of the present work indicate that human age-related cataract is associated with multiple, previously identified, and novel lens epithelial gene expression changes and provide evidence that these changes are likely to be specific for cataract and not due to aging of the lens, have identified multiple genes that respond to the presence of insults associate with human cataract and implicate an important role for specific genes in the maintenance of lens transparency. Together, these data provide the foundation for some of the molecular events associated with human age-related cataract, categorize multiple pathways that may play critical roles in the development of cataract and provide evidence for essential functions of specific genes in protecting lens cells against oxidative stress.
\end{abstract}




\section{TABLE of CONTENTS}

Grant Support.

Page

iv

Manuscripts Published as a Result of my Work............................ v

Preface.................................................................. vi

List of Abbreviations.................................................... ix

Chapter I, Introduction...............................................

Chapter II, Methods and Materials......................................... 9

Chapter III, Decreased ribosomal protein synthesis in cataract................ 29

Introduction............................................... 31

Results................................................... 34

Discussion.......................................................

Chapter IV, Gene expression profiles of human cataract.................... 55

Introduction......................................................... 58

Results........................................................ 62

Discussion........................................................ 104

Chapter V, Gene expression profiles of aging human lenses................. 113

Introduction................................................. 115

Results...................................................... 118

Discussion....................................................... 124

Chapter VI, Metal gene induction and content in human lenses.............. 129

Introduction.................................................. 131

Results....................................................... 136

Discussion...................................................... 154

Chapter VII, MsrA protects HLEs against oxidative stress.................. 158

Introduction................................................ 160

Results........................................................ 163

Discussion....................................................... 176

Chapter VIII, Conclusions............................................ 181

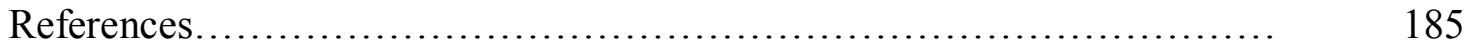




\section{Grant Support}

This work was supported by an award from the National Eye Institute EY13022 (Marc Kantorow). 


\section{Manuscripts Published as a Result of my Work}

1. Weiyan Zhang, John Hawse, Quingling Huang, Nancy Sheets, Kevin Miller, Joseph Horwitz and Marc Kantorow. Decreased expression of ribosomal proteins in human age-related cataract. Investigative Ophthalmology and Visual Science. 2002, 43, 198-204.

2. John R. Hawse, Jonathan R. Cumming, Brian Oppermann, Nancy L. Sheets, Venkat N. Reddy and Marc Kantorow. Activation of metallothioneins and alphacrystallin/sHSPs in human lens epithelial cells by specific metals and the metal content of aging clear human lenses. Investigative Ophthalmology and Visual Science. 2003, 44, 672-679.

3. John R. Hawse, James F. Hejtmancik, Quingling Huang, Nancy L. Sheets, Douglas A. Hosack, Richard A. Lempicki, Joseph Horwitz, Marc Kantorow. Identification and functional clustering of global gene expression differences between human age-related cataract and clear lenses. Molecular Vision. 2003, 9, 515-537.

4. John R. Hawse, Marc Kantorow. Gene expression profiles of human age-related cataracts. (EER invited review). 2004. (Submitted).

5. John R. Hawse, Marc Kantorow, Tracy L. Cowell, Sonia Benhamed, Gresin O. Pizarro, Venkat N. Reddy, J. F. Hejtmancik. Methionine sulfoxide reductase A protects human eye lens cells against oxidative stress damage. Proceeding of the National Academy of Science. 2004. (Submitted).

6. John R. Hawse, Candida Deamicus-Tress, Tracy Cowell, Gresin Pizarro and Marc Kantorow. A genomic level analysis of the differentiation process of human lens epithelial cells to fiber cells. Investigative Ophthalmology and Visual Science. 2004. (In Preparation). 


\section{Preface}

It seems like only yesterday. I was a naive 21 year old walking into an unfamiliar yet intriguing environment that would offer me the opportunity of a lifetime, and one that would turn the direction of my life and career upside down. I have been interested in science for as long as I can remember, always asking for those "do it yourself" science kits that each of us had as a child, and following my dad around his high school chemistry lab on the weekends helping him prepare for the next weeks lab. I enrolled in every science class that would fit into my schedule throughout my primary education and began college destined to become a biology teacher. One winter day during my junior year I learned of a job opening for an undergraduate research assistantship position in Marc Kantorow's lab. I thought that this would be a good opportunity to make a little money and see what life as a scientist was all about. I got the job, and my role in the lab began as a dishwasher and solution maker, but would quickly evolve into much more as he assisted me in developing my own research project. I was instantly hooked, and what was once intended to be a part-time job blossomed into a potential career as a scientist.

All was not easy for me during my years as a graduate student. I was instantly thrown into the middle of "professionalism" lectures and simply could not understand why it was not all right to work crossword puzzles throughout the day or go on lunch breaks as soon as the clock struck noon. There was also an overwhelming and seemingly insurmountable amount of information to be learned and I began to wonder if this was really the lifestyle for me. At times I was forced to sacrifice hunting trips, athletic events and my personal time on the weekends for long nights in the lab and quality time in front 
of the computer attempting to write manuscripts. I also experienced a move half way across the country during my final year and would have to scramble to smooth out my status as a graduate student at WVU. However, the tough times were minor in light of the fun. I have had the opportunity to travel around the country and meet some of the best scientists in the field, and if given the chance to do it all over again, I would not change a thing.

There have been many gifts and opportunities to come my way over the past three years but none have been as wonderful as the people that comprise the scientific community, whom I have had the opportunity to meet and interact with throughout my days as a graduate student. There are too many individuals to list so I will simply give my humble thanks and reflect that the last three years of my life would not have been possible, or as successful and enjoyable without them. These include Dr. Marc Kantorow, who has provided me with tremendous support, both as an undergraduate and throughout my graduate career, in the form of knowledge, guidance, enthusiasm and a comfortable and enjoyable place to work, who has taught me the many intricacies of becoming a successful teacher, advisor and researcher and who has instilled in me a general passion for science. Special mention should also be given to Dr. Jonathan Cumming, Dr. Fielding Hejtmancik, Dr. Ignacio Rodriguez, Dr. Richard Thomas and Dr. Mark Walbridge who have all provided me with expertise in the many areas of my research, who have supported me both as a friend and as an advisor throughout my graduate studies and who have enlightened me and have opened my eyes to the many aspects of biology ranging from the environment that we live in to the genetic material that defines our person. I must also thank the many graduate students and staff members 
that have become great friends and colleagues during my years at WVU. In particular, Frank Secreto, Nancy Sheets, Brian Oppermann, Katrina Klugh, Charley Kelly, Justin Haught and Charla Secreto who have all provided me with enormous insight, support, encouragement and, importantly, humor, during the many late nights in the lab and out on the town. I also thank Larry Arbogast, my high school Biology teacher, who was instrumental in providing me with a solid foundation in science, was a key factor in extracting and illuminating my curiosity for the field and who continues to support and show interest in my work. Most importantly, I thank my parents who are responsible for the person I am today, who have constantly supported me and my decisions throughout life, both in strenuous and trying times as well as in favorable and exciting times and who have given me the tools, and have exemplified the way, to live an enjoyable, peaceful and productive life.

Finally I would like to thank Mark Twain for his ongoing inspiration and would like to accentuate my appreciation of Mr. Twain and his scientific acumen with the following quote:

"In the space of one hundred and seventy-six years the Lower Mississippi has shortened itself two hundred and forty-two miles. That is an average of a trifle over one mile and a third per year. Therefore, any calm person, who is not blind or idiotic, can see that in the Old Oolitic Silurian Period, just a million years ago next November, the Lower Mississippi River was upwards of one million three hundred thousand miles long, and stuck out over the Gulf of Mexico like a fishing-rod. And by the same token any person can see that seven hundred and forty-two years from now the Lower Mississippi will be only a mile and three-quarters long, and Cairo and New Orleans will have joined their streets together, and be plodding comfortably along under a single mayor and a mutual board of aldermen. There is something fascinating about science. One gets such wholesale returns of conjecture out of such a trifling investment of fact."

- Mark Twain, Life on the Mississippi

Herein follows my wholesale return of conjecture. 


\section{List of Abbreviations}

$\begin{array}{ll}\text { AP-1 } & \text { Activation Protein-1 } \\ \text { ATP } & \text { Adenosine Triphosphate } \\ \text { BCL-1 } & \text { B-Cell Lymphoma-1 } \\ \text { BLAST } & \text { Basic Local Alignment Search Tool } \\ \text { DMEM } & \text { Dulbecco's Modified Eagle Medium } \\ \text { DTT } & \text { Dithiothreitol } \\ \text { EASE } & \text { Expression Analysis Systematic Explorer } \\ \text { ECL } & \text { Enhanced Chemi-Luminenscence } \\ \text { EF1 } \alpha 1 & \text { Elongation Factor 1 alpha 1 } \\ \text { eIF4E } & \text { Eukaryotic Initiation Factor 4E } \\ \text { FBS } & \text { Fetal Bovine Serum } \\ \text { GAPDH } & \text { Glyceraldehyde-3-Phosphate Dehydrogenase } \\ \text { gp130 } & \text { Glycoprotein 130 } \\ \text { GSH } & \text { Glutathione } \\ \text { HLEs } & \text { Human Lens Epithelial Cells } \\ \text { HSD } & \text { Honestly Significantly Different } \\ \text { HSE } & \text { Heat Shock Element } \\ \text { Hsp27-1 } & \text { Heat Shock Protein 27-1 } \\ \text { Hsp27-2 } & \text { Heat Shock Protein 27-2 } \\ \text { Hsp70 } & \text { Heat Shock Protein 70 } \\ \text { HSPs } & \text { Heat Shock Proteins } \\ \text { JMP } & \text { John's Mac Program } \\ \text { KOAc } & \text { Potassium Acetate } \\ \text { L7a } & \text { Ribosomal Large Subunit 7a } \\ \text { L13a } & \text { Ribosomal Large Subunit 13a } \\ \text { L15 } & \text { Ribosomal Large Subunit 15 } \\ \text { L21 } & \text { Ribosomal Large Subunit 21 } \\ \text { LOCS III } & \text { Lens Opacities Classification Scale-III } \\ \text { MES } & \text { 4-Morpholineethansulfonic acid monohydrate } \\ \text { MgOAc } & \text { Magnesium Acetate } \\ \text { MM } & \text { Miss-Match } \\ \text { MRE } & \text { Metal Response Element } \\ \text { Msr(s) } & \text { Methionine Sulfoxide Reductase(s) } \\ \text { MsrA } & \text { Methionine Sulfoxide Reductase A } \\ \text { MsrB } & \text { Methionine Sulfoxide Reductase B } \\ \text { MTF-1 } & \text { Metal response element-binding Transcription Factor-1 } \\ \text { MT(s) } & \text { Metallothionein(s) } \\ & \end{array}$


MTS

$\mathrm{NADH}$

NADPH

PBS

PCR

$\mathrm{PM}$

P0

Ran BP2

RT-PCR

$\mathrm{S} 3$

S20

SDS

SHSPs

siRNA

TGF- $\beta$
3-(4,5-carboxymethoxyphenyl)-2-(4-sulfophenyl)-2Htetrazolium

Nicotinamide Adenine Dinucleotide

Nicotinamide Adenine Dinucleotide Phosphate

Phosphate Buffered Saline

Polymerase Chain Reaction

Perfect Match

Ribosomal Phosphoprotein P0

Ran-Binding Protein 2

Reverse Transcriptase-Polymerase Chain Reaction

Ribosomal Small Subunit S3

Ribosomal Small Subunit S20

Sodium Dodecyl Sulfate

Small Heat Shock Proteins

Short Interfering RNA

Transforming Growth Factor Beta 


\section{Chapter I}

\section{INTRODUCTION}

\section{The Biology of the Lens.}

The role of the eye lens is to focus incoming light on the retina where visual information is processed and transmitted to the brain. In order for the lens to carry out this process it has evolved an exquisite set of proteins that protect the lens and preserve its transparent function. The lens is an interesting organ to study since it is composed of only 2 cell types, grows throughout life and contains some of the oldest cells in the body and therefore presents a unique model for examining how cumulative environmental insults and aging may impact biological systems. For this reason, the lens has classically served as a model for diverse biological processes including stress biology, protein biochemistry, development and aging.

The lens consists of a single layer of quiescent cuboidal epithelial cells on the anterior surface of the lens covering concentric layers of elongated and terminally differentiated fiber cells. The entire organ is encompassed by a basement membrane known as the lens capsule which is secreted by the epithelial cells. The lens grows throughout life as the peripheral epithelial cells eventually give rise to new fiber cells. The fiber cells nearest the epithelium makeup the lens cortex while the fiber cells in the center of the lens are referred to as the lens nucleus and are some of the oldest cells in the body. During differentiation from epithelia to fibers, lens cells elongate, produce large 
amounts of crystallin proteins and lose their organelles and therefore rely solely on the epithelium for future support and protection.

Developmentally, the lens forms from an invagination of the neural placode which eventually pinches off to create a spherical lens vesicle (Phelps Brown 1996). Formation of the lens vesicle is rapidly followed by elongation of the cells of its posterior wall which are destined to become the primary lens fibers. Additional layers of secondary fiber cells are created at the lens equator as a result of cell division, separating the primary fiber cell mass from the epithelium (Phelps Brown 1996). These same primary fiber cells occupy the center of the lens throughout life and are referred to as the lens nucleus. The specific cell types and regions of the lens are represented pictorially below.

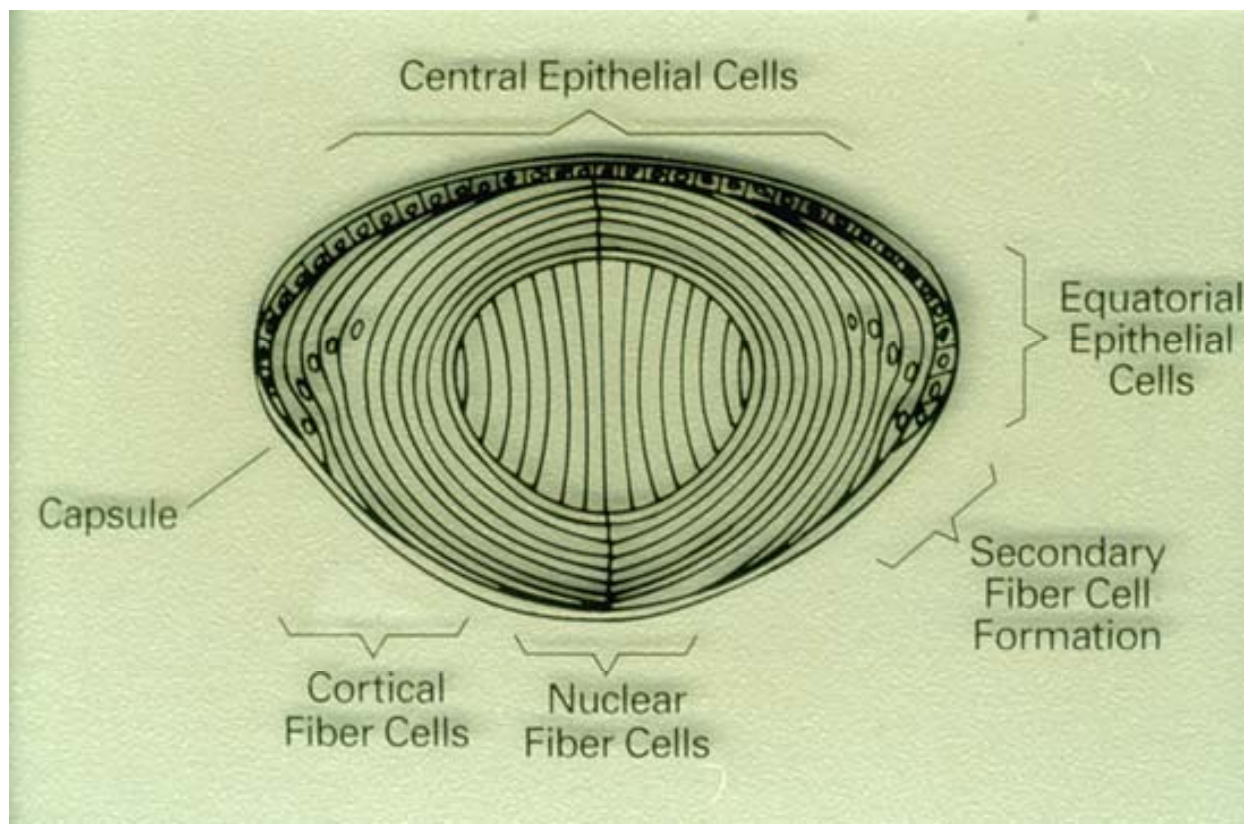

Chicken embryo lens depicting the different regions of the lens. This diagram was adapted from Beebe D, Vasiliev O, Guo J, Shui YB, and Bassnett S. Changes in adhesion complexes define stages in the differentiation of lens fiber cells. IOVS March 2001, Vol. 42, No. 3: 727-734. 
The lens is covered by an unusually thick basal lamina, referred to as the lens capsule, which is secreted by the lens epithelium during development (Parmigiani and McAvoy 1991). The capsule represents the thickest basement membrane in the body and is freely permeable to water, ions and other small molecules but offers a barrier to proteins larger than approximately $67 \mathrm{kDa}$ (Fisher 1969).

The lens epithelium is composed of cuboidal cells that form a simple epithelium covering the anterior portion of the lens. Approximately 500,000 cells make up the adult human lens epithelium (Young ) and these cells possess large nuclei and a moderate number of organelles and are responsible for the majority of transcriptional activity in the lens (Phelps Brown 1996). The epithelial cells are connected to the fiber cells through gap junctions and there is no significant barrier to extracellular flow between lens epithelial cells (Goodenough et al 1980; Rae and Stacey 1979). These gap junctions likely allow the lens epithelium to respond to changes in the fiber cells through altered gene expression. Very few mitosis events occur in the central region of the lens epithelium but are more frequent in the germinative zone. This area of the epithelium is composed of highly ordered meridional rows of cells that differentiate into secondary fiber cells.

Fiber cells undergo a process of terminal differentiation during which they lose their nuclei and all other organelles. Superficial lens fiber cells contain sparse organelles that are eventually lost from the deep cortex and the lens nucleus. Lens fibers are ribbonshaped cells that are hexagonal in cross-section and are joined together by both ball and socket (Phelps Brown 1996) and tongue and groove joints (Kuwabara 1975). 


\section{Age-Related Cataract.}

Age-related cataract is the major disease of the lens and is defined as any opacity of the lens that results in light scattering. Age-related cataract is the major cause of world blindness (Congdon et al., 2003), is the most commonly performed surgical procedure in people over 65 and is the leading cause of morbidity and functional impairment in the elderly. Surgery is the only know treatment for this disease and cataract surgery currently accounts for approximately $12 \%$ of the entire Medicare budget (Stark et al., 1989). With the average age of the US population increasing, cataract is, and will continue to be, a major economic and quality of life concern. Despite its importance, age-related cataract is a multifactorial disease with a poorly understood etiology. Among the many factors that can lead to cataract, oxidative stress coupled to UV-light exposure and exposure to ionizing radiation are believed to play major roles (Spector, 1984)

A key player in lens maintenance and defense is the lens epithelium which is the first part of the lens exposed to environmental insults. The lens epithelium also contains the highest activities of enzymes and transport systems in the lens (Reddan JR. 1982; Reddy 1971b; Spector 1982a) and damage to this portion of the lens and these systems has been shown to be associated with cataract formation (Harding JJ 1984; Phelps Brown 1996; Spector 1995). These properties of the lens epithelium suggest that it is likely to have evolved mechanisms to defend itself against environmental stress. Repeated exposure of the lens to multiple stresses is known to cause cataract formation and alter the gene expression profiles of the lens epithelium. 


\section{Oxidative Stress and Age-Related Cataract.}

One major insult to the lens epithelium is oxidative stress which is known to be associated with numerous age-related diseases including Alzheimer's and Parkinson's disease, age-related macular degeneration and age-onset cataract (Beatty et al 2000). Oxidative stress occurs when the level of reactive oxygen species and other free radicals exceeds the ability of a cell to respond through antioxidant defense systems and ultimately leads to protein modification and degradation, DNA and mitochondrial damage and eventual cell death (Fukagawa et al 2000; Rosen et al 2001). The lens is especially prone to oxidative damage since the fiber cells of the lens are not renewed and therefore must last a lifetime. Accumulated damage to these fiber cells is likely to result in protein degradation, aggregation and ultimately cataract.

A number of epidemiologic and experimental studies support the idea that ultraviolet light plays a role in oxidative stress and cataract formation. Interactions of UV-light with ascorbate and other molecules present in the aqueous humor result in the production of $\mathrm{H}_{2} \mathrm{O}_{2}$. Organ culture experiments have shown that acute oxidative stress induced by $\mathrm{H}_{2} \mathrm{O}_{2}$ treatment is capable of irreversible damage to the lens epithelium resulting in cell death and cataract (Spector 1995). UV irradiation of rat lenses has been shown to cause photochemical alterations of tryptophan residues in lens proteins, ultraviolet absorption bands attributed to photo-oxidation products of lens proteins and cross-linking of polypeptides in lens proteins (Borkman 1984). Additional studies have shown that UV photons interact with proteins in epithelial cell membranes damaging the ion pumps and channels (Hightower 1994). Accumulated damage to these pumps and 
channels over time results in the loss of homeostatic control of ions (Hightower 1994). This loss of homeostasis results in damage to the crystallin proteins in the underlying fiber cells leading to opacification of the lens (Hightower 1994).

\section{Toxic Metals and Age-Related Cataract.}

In addition to UV-light, toxic metals such as iron, copper, cadmium, lead, aluminum and others have been demonstrated to be associated with cataract formation. Human exposure to these metals arises from wide-spread sources including cigarette smoke, air pollution, leaching of landfills, industrial waste, emissions from fossil fuels, fertilizers and corrosion of plumbing (Artic Monitoring and Assessment Program (AMAP). 2000; Ruffett et al 1992). Indeed, increased cadmium levels have been reported in cataract versus clear human lenses (Ramakrishnan et al 1995) and iron and copper participate in Fenton-type reactions which are known to be associated with oxidative stress and cataract (Phelps Brown 1996). Defects associated with metal transport systems in the lens, including hyperferritinemia (Girelli et al 1995), Wilson's disease and Menkes disease (Cuthbert 1998) result in the formation of specific types of human cataract.

\section{Protective Systems in the Lens.}

To combat damage resulting from oxidative stress, UV-light and toxic metal exposure, the lens has evolved numerous protective systems making it an excellent model 
for studying the biology of aging and the molecular mechanisms associated with these insults and this disease. The lens contains high levels of reduced glutathione (Giblin 2000), abundant antioxidant enzymes (Phelps Brown 1996) and the chaperone-like functions of the crystallins (Horwitz 1992) which are likely to play pivotal roles in protecting the lens against damage associated with these stresses. Previous work has provided evidence that the human lens epithelium is capable of responding to the presence of multiple insults and cataract through the altered expression of many genes including metallothionein IIa (Oppermann et al 2001a), thioltransferase (Xing and Lou 2002), catalase (Reddan et al 1996), glutathione peroxidase (Spector et al 2001) and multiple glutathione S-transferases (Phelps Brown 1996). These data provide evidence that the lens is capable of dynamic responses to environmental insults such as oxidative stress, toxic metals and UV-light exposure.

\section{This Dissertation.}

Age-related cataracts have been linked to many interrelated environmental, physiological and genetic components (Harding JJ 1984; Hightower 1995; Phelps Brown 1996; Spector 1982a; Spector 1984; Spector 1995) and it is therefore unlikely that any one study will identify a comprehensive therapy for the treatment of this disease. However, it has been estimated that a 10 year delay in the onset of age-related cataract would halve the number of people requiring cataract surgery in their lifetime, dramatically increase the quality of life and significantly decrease the cost of health care (Kupfer 1994). In light of the elaborate and interactive mechanisms involved in lens 
defense against insults associated with cataract and the limited knowledge of the gene expression changes that occur in the lens upon cataract formation, I sought to define those genes and their associated pathways that are altered in the presence of cataract and to begin defining the functional roles of these systems in the lens. Understanding the functions of these genes will aid in the development of therapies to delay or possibly prevent cataract formation.

Specifically I have established the groundwork for the molecular events accompanying the presence of cataract and aging of the human lens, have identified specific genes induced by the presence of metals in lens epithelial cells that are likely to protect against the toxic effects of heavy metal insult and have provided evidence for a potential role of MsrA in defending lens cells against oxidative stress through repair of oxidized methionine residues. The work leading to these conclusions is specifically described in a segmented format below. 


\section{Chapter II}

\section{METHODS and MATERIALS}

\section{Isolation of RNA from human lenses for differential display.}

Clear human lenses were received on ice within 24 hours post-mortem. Lenses were microscopically examined for any sign of opacity. Those exhibiting signs of opacity were excluded from the present study. For the differential display and semiquantitative RT-PCR procedures, 6-8mm of central epithelia from clear lenses were dissected and contaminating fiber cells removed using a dissecting microscope (Straatsma et al 1984). Age-related cataract epithelia (4-6mm of central epithelia) were obtained within minutes after surgery and contaminating fibers removed identically (Straatsma, Horwitz, Takemoto, Lightfoot, and Ding 1984). For the spatial analysis studies, whole normal lenses were dissected into central epithelia (4-6mm), peripheral epithelia (the outermost 2-3mm), whole fibers (the rest of lens minus the epithelium and capsule) and cortical fibers (2-3mm excluding the nuclear fibers). Normal epithelia averaged 60 years old and were $60 \%$ male, while cataract epithelia averaged 71 years old and were $45 \%$ male. The cataract epithelia in this study represent the normal population receiving cataract surgery at the Jules Stein Eye Institute, Los Angeles, CA and were obtained and classified by the same surgeon using a modified version of the LOCSIII grading system. The cataracts used in this study were approximately $70 \%$ mixed, $20 \%$ nuclear, $5 \%$ cortical and $2 \%$ posterior sub-capsular. With the exception of cataract-type, 
age and sex no further identifying information was available for individual lenses. Total RNA was prepared from all samples using the RNeasy kit as specified by the manufacturer (Qiagen,Valencia, CA) and quantified as previously described (Kantorow et al 1998a). For RT-PCR-differential display, RNA samples were treated with RNasefree DNaseI to remove possible DNA contamination (Sambrook J 1989).

\section{Reverse transcriptase-PCR-differential display.}

Differential display reactions were performed in duplicate to reduce the potential for artifacts. First-strand cDNA synthesis: Duplicate samples of 200ng cataractous and normal RNA were subjected to reverse transcription using $0.2 \mu \mathrm{M}$ of an anchored primer (AP1) of sequence 5'-ACGACTCACTATAGGGCTTTTTTTTTTTTAA-3' containing the $\mathrm{T} 7$ promoter sequence (underlined), a T12 anchoring sequence, and two anchoring bases. First-strand synthesis was performed by incubation at $25^{\circ} \mathrm{C}$ for 10 minutes, $42^{\circ} \mathrm{C}$ for 60 minutes, and $70^{\circ} \mathrm{C}$ for 15 minutes, in the presence of $25 \mu \mathrm{M}$ each deoxyribonucleoside triphosphates, 10mM DTT, 20U RNasin (Promega, Madison, WI) and $40 \mathrm{U}$ reverse transcriptase (Superscript II; GIBCO-BRL, Gaithersburg, MD) in a volume of $20 \mu 1$ reverse transcription buffer $\left(50 \mathrm{mM}\right.$ Tris, $\mathrm{pH} 8.3,6 \mathrm{mM} \mathrm{MgCl}_{2}, 10 \mathrm{mM}$ $\mathrm{KCl})$.

Amplification of Double-Stranded cDNA Fragments: Double-stranded cDNAs were generated by PCR using two different primer sets. Both reactions used $0.2 \mu \mathrm{M}$ of the anchored first-strand synthesis primer (above). Separate reactions employed either $0.2 \mu \mathrm{M}$ of arbitrary annealing primer one (AR1; 5 '- 
ACAATTTCACACAGGACGACTCCAAG-3') or arbitrarily annealing primer 2 (AR2; 5'-ACAATTTCACACAGGAGCTAGCATGG-3'). Both primers contain the M13 reverse sequence (underlined). PCR was performed with 1U Taq polymerase (AmpliTaq; PerkinElmer, Norwalk, CT) in the presence of $2.5 \mu \mathrm{Ci}\left[\alpha-{ }^{33} \mathrm{P}\right]$-deoxyadenosine triphosphate (1000-3000 Ci/mmol; New England Nuclear-Dupont, Boston, MA), 1.5mM $\mathrm{MgCl}_{2}$, and $100 \mu \mathrm{M}$ deoxynucleoside triphosphates, in a reaction volume of $20 \mu 1$. PCR cycles were: $1 \mathrm{PCR}$ cycle at $95^{\circ} \mathrm{C}$ for 2 minutes; $4 \mathrm{PCR}$ cycles at $92^{\circ} \mathrm{C}$ for 15 seconds, $46^{\circ} \mathrm{C}$ for 30 seconds and $72^{\circ} \mathrm{C}$ for 2 minutes; 25 PCR cycles at $92^{\circ} \mathrm{C}$ for 15 seconds, $60^{\circ} \mathrm{C}$ for 30 seconds, $72^{\circ} \mathrm{C}$ for 2 minutes; and $1 \mathrm{PCR}$ cycle at $72^{\circ} \mathrm{C}$ for 7 minutes. After amplification, $\left[\alpha-{ }^{33} \mathrm{P}\right]$-labeled cDNA fragments were separated by electrophoresis on $4.5 \%$ polyacrylamide, $8 \mathrm{M}$ urea gels and visualized by autoradiography.

Re-amplification of Differentially Displayed Bands: Bands of differing intensity, and two unchanged bands (as controls), between the cataract and the normal samples were excised from the gel and the resultant gel slices were directly subjected to PCR. cDNAs were bi-directionally amplified with $0.2 \mu \mathrm{M}$ each full-length $\mathrm{T} 7$ primer (5'GTAATACGACTCACTATAGGGC-3') and M13 reverse (-48)sequencing primers (5'-AGCGGATAACAATTTCACACAGGA-3'). The PCR conditions and cycles used in these procedures were identical with those described for amplification of doublestranded cDNA fragments, except that $\left[\alpha-{ }^{33} \mathrm{P}\right]$-deoxyadenosine triphosphate was omitted from the reaction mixture. Products were separated by electrophoresis on $1.2 \%$ agarose gels and visualized by ethidium bromide staining. 


\section{Cloning and Sequence Analysis of Differentially Displayed cDNAs.}

Re-amplified differentially displayed bands were analyzed by electrophoresis on $1.2 \%$ agarose gels. The products were cloned into the TOPO TA cloning vector (Invitrogen, San Diego, CA), according to manufacturer's instructions. Cloned differentially displayed products were sequenced by fluorescent dye terminator cycle sequencing as specified by the manufacturer (Perkin-Elmer Applied Biosystems, Warrington, UK), using a sequencing primer (5'-GCTCGGATCCACTAGTAACGG-3') complementary to the vector (TOPO TA) SP6 sequence. Reactions were run and sequences analyzed on an Applied Biosystems model 373A DNA sequencer. Sequences were further analyzed using the BLAST algorithm with the GenBank data base and sequence alignments were performed using the MegAlign program contained in the Lasergene software package (DNASTAR, Madison,WI) to determine the genes represented by the differentially displayed bands.

\section{Semi-quantitative RT-PCR confirmation of differentially displayed bands.}

Semi-quantitative RT-PCR was performed by modification of established procedures (Kantorow, Horwitz, and Carper 1998a; Sambrook J 1989). RNA from individual samples was examined using the one-step system according to the manufacturer (GIBCO-BRL, Gaithersburg, MD). Primers were designed to cross intronexon boundaries. The primer concentration of $200 \mathrm{nM}$ used in these experiments was chosen to ensure that the amount of primers would not be limiting. Control reactions 
used primers specific for human $\beta$-actin and GAPDH. PCR cycling parameters (20-25 cycles) were chosen to ensure linear product formation over the amounts of RNA and other reagents described. The sequences of the gene-specific primers used to amplify the $\beta$-actin, GAPDH, L21, gp130, L15, L13a, L7a, eIF4E and EF1 $\alpha 1$ transcripts along with their corresponding GenBank accession numbers and annealing temperatures are shown in Table 1 in chapter III. Products were separated on 1.2\% agarose gels and visualized by ethidium bromide staining. Reaction products were sequenced to ensure they represented the authentic transcripts. Where indicated $1 \mathrm{uCi}$ of $\left[1000-3000 \mathrm{mCi} / \mathrm{mmol},\left[\alpha-{ }^{33} \mathrm{P}\right]-\right.$ deoxyadenosine triphosphate was added to each RT-PCR reaction and incorporated radioactivity was monitored by scintillation counting of excised RT-PCR products.

\section{Tissue collection and RNA preparation for oligonucleotide microarray hybridization.}

Central lens epithelial tags $\left(2-3 \mathrm{~mm}^{2}\right)$ were obtained from patients undergoing cataract surgery at the Jules Stein Eye Institute, UCLA School of Medicine. The cataracts are representative of the entire population of patients undergoing cataract surgery and were obtained and classified by the same surgeon, according to a modified version of the Lens Opacities Classification Scale (LOCS)-III grading system. The cataracts used in this study were approximately $70 \%$ mixed, $20 \%$ nuclear, $5 \%$ cortical and $2 \%$ posterior sub-capsular. With the exception of cataract-type, age and sex, no further identifying information was available for individual lenses. Clear whole human lenses were obtained from organ donors within 24 hours post-mortem from the Lions Eye 
Bank of Oregon and the West Virginia Eye Bank. Whole lenses were microscopically examined for opacities and those lenses exhibiting opacity were discarded from the present study. Clear lenses were microdissected for central epithelium $\left(6-8 \mathrm{~mm}^{2}\right)$ and contaminating fiber cells were removed. A total of 106 cataracts (average age 71.2 years) and 10 clear lens epithelia (average age 64.2 years) were used to obtain sufficient amounts of RNA (2-5 $\mu \mathrm{g})$ for the microarray study. An additional 50 cataracts (average age 70.8 years) and 10 clear lens epithelia (average age 63.3 years) were used for the secondary semi-quantitative RT-PCR confirmation studies. Another 50 cataracts (average age 68.7 years) and 10 clear lens epithelia (average age 57.0 years) were used for the control and tertiary semi-quantitative RT-PCR confirmation studies. Total RNA was isolated from these samples using the Trizol method.

For gene expression differences between young and old lens epithelia, total RNA was isolated from 10 pooled young lens epithelia, average age 32.3 years, and 10 pooled old lens epithelia, average age 64.2 years. All lenses were collected from the Lion's Eye Bank of Oregon and the West Virginia Eye Bank, examined to be free of any opacity and microdissected to separate the lens epithelium from the underlying fiber cells.

\section{Microarray procedure and analysis.}

The quality and quantity of RNA obtained from the cataract and clear lens epithelial tags was determined using a Bioanalyzer 2100 (Agilent Technologies) according to the manufacturers protocol. Briefly, a small amount of RNA from each sample was loaded on a microgel, electrophoresed, scanned and analyzed for the quantity 
and integrity of the $18 \mathrm{~s}$ and $28 \mathrm{~s}$ ribosomal RNA bands to ensure that the same amount of RNA was examined for both the cataract and clear lens samples.

First and second strand cDNAs were synthesized from 2-5 $\mu \mathrm{g}$ of total RNA using the SuperScript Double-Stranded cDNA Synthesis Kit (Invitrogen, Gaithersburg, MD) and the oligo-dT 24 -T7 primer (5'-GGCCAGTGAATTGTAATACGACTCACTATAGGGAGGCGG-3') according to the manufacturer's instructions. cRNA was synthesized and labeled with biotinylated UTP and CTP by in vitro transcription using the T7 promoter coupled double-stranded cDNA as a template and the T7 RNA Transcript Labeling Kit (ENZO Diagnostics Inc.). Briefly, double-stranded cDNAs synthesized from the previous steps were washed twice with $70 \%$ ethanol and resuspended in $22 \mu 1$ of RNase-free $\mathrm{H}_{2} \mathrm{O}$. The cDNA was incubated with $4 \mu \mathrm{l}$ each of 10X Reaction Buffer, Biotin Labeled Ribonucleotides, DTT, RNase Inhibitor Mix and $2 \mu 1$ of $20 \mathrm{X}$ T7 RNA Polymerase for 5 hours at $37^{\circ} \mathrm{C}$. The labeled cRNA was separated from unincorporated ribonucleotides by passing through a CHROMA SPIN-100 column (Clontech) and precipitated at $-20^{\circ} \mathrm{C}$ for 1 hour to overnight.

The cRNA pellet was resuspended in $10 \mu \mathrm{l}$ of RNase-free $\mathrm{H}_{2} \mathrm{O}$ and $10 \mu \mathrm{g}$ was fragmented by heat and ion-mediated hydrolysis at $95^{\circ} \mathrm{C}$ for 35 minutes in $200 \mu \mathrm{M}$ Trisacetate, $\mathrm{pH}$ 8.1, $500 \mathrm{mM} \mathrm{KOAc,} 150 \mathrm{mM}$ MgOAc. The fragmented cRNA was hybridized for 16 hours at $45^{\circ} \mathrm{C}$ to $\mathrm{HG}_{-} \mathrm{U} 133 \mathrm{~A}$ oligonucleotide arrays (Affymetrix) containing 22,283 probe sets representing 22,215 gene or extended sequence tag (EST) sequences. Arrays were washed at $25^{\circ} \mathrm{C}$ with $6 \mathrm{X} \mathrm{SSPE}\left(0.9 \mathrm{M} \mathrm{NaCl}, 60 \mathrm{mM} \mathrm{NaH}_{2} \mathrm{PO}_{4}\right.$, $6 \mathrm{mM}$ EDTA and $0.01 \%$ Tween-20) followed by a stringent wash at $50^{\circ} \mathrm{C}$ with $(100 \mathrm{mM}$ MES, $0.1 \mathrm{M}[\mathrm{Na}+]$, and $0.01 \%$ Tween-20). The arrays were then stained with 
phycoerythrein-conjugated streptavidin (Molecular Probes) and the fluorescence intensities were determined using a laser confocal scanner (Hewlett-Packard).

The scanned images were analyzed using Microarray Suite 5.0 software (Affymetrix), following user guidelines. Briefly, background signal intensities were calculated and used to determine if the signal intensity of an individual gene was statistically greater than the background intensity value. The signal intensity for each gene was calculated as the average intensity difference, represented by $[\Sigma(\mathrm{PM}-$ $\mathrm{MM}) /($ number of probe pairs)], where PM and MM denote perfect-match and mismatch probes respectively. Each reported gene value represents the average signal intensity of 10 separately hybridized gene signatures. Any gene whose MM value was saturated or fell within tau $(\tau)$ distance of the PM value was excluded from the analysis. Tau is a parameter used in performing the One-Sided Wilcoxon's Signed Rank test for the detection call and represents a threshold that the discrimination score for a probe set must exceed in order for a gene to be regarded as being present in the sample. Each gene was then assigned a call of Present $(\mathrm{P})$, meaning that its intensity value is statistically greater than that of the background level and/or falls outside of the calculated $\tau$ distance, or Absent (A) meaning that its intensity value is not statistically greater than that of the background level and/or falls within the calculated $\tau$ distance. All of the genes described in these studies are rated as present in at least one, if not both, of the cataract and clear lens samples or the young and old lens epithelia samples. Any gene that was determined to be absent in both of the compared samples was eliminated from these studies.

The microarray data were normalized using the Microarray Suite 5.0 software (Affymetrix) by multiplying the output of the experimental array by a Normalization 
Factor so that its average intensity was the same as that of the baseline array. The Microarray Suite 5.0 software also requires scaling, in which the output of any array is multiplied by a scaling factor to make its average intensity equal to a defined target intensity. For these studies a standard target intensity of 250 was used.

\section{Semi-quantitative RT-PCR confirmations of differentially expressed genes by microarray hybridization.}

Indicated genes were selected for use in semi-quantitative RT-PCR confirmations of the hybridization results for the cataract and clear lens epithelial samples. Genespecific primers were designed using the BLAST program and GenBank database (http://www.nlm.nih.ncbi.gov/, National Center for Biotechnology Information, Bethesda, MD). All primers were designed to cross intron/exon boundaries. The primer sequences, GenBank accession numbers, annealing temperatures, product lengths and PCR cycle numbers for all gene-specific primers used in the cataract and clear lens study are indicated in Table 1 in chapter IV. Semi-quantitative RT-PCR was performed using 50 ng of RNA with a commercial RT-PCR system used in accordance with the manufacturer's protocol (One-Step; Invitrogen, Gaithersburg, MD). Control genes were also examined to provide further confidence in the data and to show that the PCR reactions used were within the linear range of PCR cycles. Products were separated by gel electrophoresis on $1.5 \%$ agarose gels and visualized by ethidium bromide staining. Product formation for indicated genes was linear over all of the PCR cycles used. All PCR products were sequenced to ensure product authenticity. All gels were scanned and 
the $\%$ adjusted volume intensities of all of the RT-PCR products were determined using a Biorad gel documentation system (Biorad). These values were used to calculate the approximate fold changes of the selected genes in the RNA samples analyzed.

\section{Functional clustering and over-representation analysis of differentially expressed genes.}

Genes identified to be differentially expressed by 2-fold or greater according to the microarray analysis were analyzed for significant functional clusters of genes using the EASE bioinformatics software package (http://david.niaid.nih.gov/david/ease.htm). This software package was used to rank functional clusters by statistical overrepresentation of individual genes in specific categories relative to all genes in the same category on the microarray. The functional clusters used by EASE were derived from the classification systems of the Gene Ontology (http://www.geneontology.org/), Proteome's "At A Glance" (http://www.incyte.com/sequence/proteome/databases/HumanPSD.shtml), SwissProt keywords (http://us.expasy.org/cgi-bin/keywlist.pl) and Interpro protein domains (http://www.ebi.ac.uk/interpro/).

\section{Human lens epithelial cell culture.}

Human lens epithelial cells (HLEs) (SRA01/04) (Ibaraki et al 1998) were grown and cultured in Dulbecco's modified Eagle's medium supplemented with 15\% fetal bovine serum, gentimycin (50 units/ml, Invitrogen, Gaithersburg, MD) and PSN 
(penicillin-streptomycin-neomycin) antibiotic mix (50units/ml, Invitrogen, Gaithersburg, $\mathrm{MD})$, at $36.5^{\circ} \mathrm{C}$ in the presence of $5 \% \mathrm{CO}_{2}$.

The methods for establishing primary cultures of human lens epithelium have been described previously (Arita et al 1988). Briefly, pieces of capsule and epithelium obtained from infants who underwent surgery for retinopathy of prematurity were washed once with $\mathrm{Ca}^{+2}$ and $\mathrm{Mg}^{+2}$ free phosphate buffered saline and collected with a micro suction pipette. Small fragments of capsule (1-2 $\left.\mathrm{mm}^{2}\right)$ with epithelial cells attached were placed in a 60mm culture dish in Dulbecco's modified Eagle's medium supplemented with $20 \%$ fetal calf serum (Falcon; Becton-Dickenson, Oxnard, CA, USA) as explants until a confluent monolayer was formed in approximately two weeks.

Cells from explant-cultures were dissociated with trypsin-EDTA solution (Invitrogen, Grand Island, NY, USA) and collected by centrifugation. They were subcultured in the initial medium at $36.5^{\circ} \mathrm{C}$ in a humidified atmosphere with $5 \% \mathrm{CO}_{2}$. The procedure was repeated for additional subcultures.

\section{Metal treatments.}

Cells were exposed to the indicated concentrations of $\mathrm{CdCl}_{2}, \mathrm{CuCl}_{2}$ and $\mathrm{ZnCl}_{2}$ dissolved in water as previously described (Foster et al 1988) and optimal induction conditions were determined. At indicated times, cells were washed with PBS and total RNA was isolated by Trizol (Invitrogen, Gaithersburg, MD) extraction as specified by the manufacturer. Cell viability in response to metal treatment was assessed by trypan 
blue exclusion (Ausubel I 1998). Cell viability is expressed as the standard deviation for three separate cell populations treated identically.

\section{Semi-quantitative RT-PCR examination of gene induction by metals.}

Gene-specific primers were designed using the BLAST program and GenBank data base (National Library of Medicine, Bethesda, Maryland). Primer sequences, Genbank accession numbers, annealing temperatures and product lengths for all genespecific primers used in this study are indicated in Table 1 in chapter VI. RT-PCR was performed with $100 \mathrm{ng}$ of RNA using the One-Step RT-PCR system according to the manufacturer (Invitrogen, Gaithersburg, MD). Products were separated by gel electrophoresis on $1.5 \%$ agarose gels and visualized by ethidium bromide staining. Products were sequenced to ensure specificity. Product formation for indicated genes was linear over 20 to 30 PCR cycles.

\section{Quantitative mimic RT-PCR.}

PCR mimics, identical in sequence to the MTIIa and MTIg cDNA sequences with the exception of a $138 \mathrm{bp}$ internal deletion (bps +18 to +155 from the start of translation) for the MTIIa mimic and a 118 bp internal deletion (bps +18 to +135 from the start of translation) for the MTIg mimic, were synthesized and used to compete with endogenous MT cDNAs. Indicated transcripts were reverse-transcribed and amplified in the presence or absence of the PCR mimics using the One Step RT-PCR system as recommended by the manufacturer (Invitrogen, Gaithersburg, MD) and the same primers and conditions described for RT-PCR above. The MT PCR mimics contain the same primer binding 
sites and sequences as the endogenous MT mRNAs except for the indicated deletions.

The amount of MTIIa or MTIg mimic required to equally compete with a fixed amount of total RNA is proportional to the amount of transcript present. Increasing amounts $(0.1$ to $500 \mathrm{pg}$ ) of mimic DNA template competed with a constant amount of RNA (300 $\mathrm{ng}$ ) in the presence or absence of $1.0 \mu \mathrm{Ci}$ of $\alpha^{32} \mathrm{P}-\mathrm{CTP}(250 \mu \mathrm{Ci} / \mathrm{mmol})$ (Amersham Biosciences, Piscataway, NJ). MTIIa products were excised from the gel and incorporated radioactivity monitored by scintillation counting. The resulting counts were corrected for background and the number of cytosine residues present in each PCR product. The amount of MTIIa transcript per ng of total RNA was determined by calculating the amount of mimic DNA (cpms) required to equally compete with the endogenous transcript present in the $300 \mathrm{ng}$ of total RNA (cpms).

\section{Analysis of metal content in clear human lenses.}

Forty-five clear, decapsulated human lenses ranging from 21 years of age to 72 years of age were dried in a $60^{\circ} \mathrm{C}$ incubator overnight. Dry weights for individual lenses were determined. Triplicate groups of 5; young lenses, average age (25.8, 34.2 and 38.4 years) respectively, middle-aged lenses, average age (51.6, 53.0 and 54.8 years) respectively, and old lenses, average age $(69.2,70.6$ and 71.8 years) respectively, were pre-digested overnight in $5 \mathrm{~mL}$ concentrated $\mathrm{HNO}_{3}$, after which $3 \mathrm{~mL}$ of $30 \% \mathrm{H}_{2} \mathrm{O}_{2}$ was added. Digests were heated to $120^{\circ} \mathrm{C}$ (Jones JB Jr 1999). Upon cooling, samples were brought to a final volume of $50 \mathrm{~mL}$ with de-ionized water and then filtered $(0.2 \mu \mathrm{m})$. Samples were assayed for elemental metal concentrations by inductively coupled plasma emission spectroscopy (ICP) by the Analytical Laboratory at the National Research 
Center for Coal and Energy at West Virginia University. Elemental concentrations for each sample were corrected for differences in dry weights. Differences between age group means were explored by analysis of variance and the Tukey-Kramer HSD procedure using the statistical package JMP (SAS Institute, Cary, NC).

\section{Estimation of MsrA transcript levels in human tissues.}

The relative levels of MsrA transcript in 5 pooled whole human lenses was compared with 18 other human tissues included in a total RNA tissue panel (BD Biosciences Palo Alto, CA). Gene specific primers were designed for the human MsrA and GAPDH gene using the BLAST program and GenBank database (http://www.nlm.nih.ncbi.gov/), National Center for Biotechnology Information, Bethesda, MD). Total RNA was isolated from whole lenses and RT-PCR was performed as described above. The sequences of the primers used in this study were: MsrA forward 5'-AGTACCTGAGCAAGAACCCCA-3', MsrA reverse 5'-TCACTCAGACCCCAGAAGACA-3', GAPDH forward 5'-CCACCCATGGCAAATTCCATGGCA-3' and GAPDH reverse 5'-TCTAGACGGCAGGTCAGGTCCACC-3'. MsrA transcript was amplified for $34 \mathrm{PCR}$ cycles with an annealing temperature of $56^{\circ} \mathrm{C}$. GAPDH transcript was amplified for $25 \mathrm{PCR}$ cycles using an annealing temperature of $60^{\circ} \mathrm{C}$. All reactions were conducted using $100 \mathrm{ng}$ of RNA and reagents contained in a commercial RT-PCR kit (One-Step kit, Invitrogen, Gaithersburg, MD) according to the manufacturer's protocol. Products were separated by gel electrophoresis and all products were 
sequenced to ensure authenticity. Product formation was tested to be linear over the number of PCR cycles indicated. Densitometric scanning of the gel was performed to determine the relative levels of PCR products using an Epi Chemi II Darkroom gel documentation system (UVP Laboratory Products, Upland, CA). These intensity values were used to calculate relative MsrA transcript production by normalizing the level of reach sample with its corresponding GAPDH level. The adjusted values were used to rank the tissues form 1-19 with 1 being the highest level of MsrA expression and 19 being the lowest.

\section{Analysis of MsrA transcript and protein levels in microdissected components of whole human lenses.}

The relative levels of MsrA transcript and protein was estimated between microdissected portions of adult human lenses by semi-quantitative RT-PCR and western analysis. Eight clear human lenses were microdissected to remove the lens epithelium from the underlying fiber cells. The fiber cells were further dissected into cortical and nuclear components. RT-PCR was performed using $100 \mathrm{ng}$ of total RNA as described above. Protein was isolated from microdissected lens epithelia, cortical fibers and nuclear fibers by sonication. Protein was denatured by boiling in $10 \%$ SDS buffer $(10 \%$ w/v SDS; 0.5 M Tris-HCL, pH 6.8; 5\% [v/v] glycerol) and were resolved by electrophoresis on $12 \%$ SDS polyacrylamide gels. The proteins were subsequently transferred to nitrocellulose filters. The resulting blots were washed with PBS for 30 minutes and blocked with 5\% milk in PBS overnight. The blot was washed 5 times with 
PBS over a period of 30 minutes and incubated with a 1:2000 dilution of anti-MsrA antibody for 1 hour at room temperature. The blot was washed 5 times over a period of 30 minutes and immunoreactive MsrA was visualized using ECL western blotting reagents (Amersham-Pharmacia, Piscataway, NJ) as specified by the manufacturer.

\section{Spatial localization of MsrA protein in an intact human lens.}

An 18-year-old female human lens ( $<24$ hours post-mortem) was fixed in $4 \%$ Para formaldehyde in PBS overnight, followed by cryoprotection overnight in $30 \%$ sucrose in PBS before embedding. Frozen sections $(14 \mu \mathrm{m})$ were prepared and air-dried. Sections were blocked for 1 hour at room temperature in DMEM, 10\% fetal calf serum, $1 \%$ goat serum, and $0.1 \%$ Triton X-100. Sections were incubated overnight with a 1:2000 dilution of anti-MsrA antibody in blocking solution at $4{ }^{\circ} \mathrm{C}$. After five washes with PBS containing $0.1 \%$ Tween-20, sections were incubated with streptavidinconjugated secondary antibody and were visualized using the Vectastain Elite Kit as specified by the manufacturer. Sections were counterstained with hematoxylin. Identical procedures were carried out in the absence of primary antibody as control.

\section{SRA01/04 and 293-FT cell culture.}

Human lens epithelial cells (SRA01/04) (HLEs) and 293-FT kidney cells were grown and cultured in Dulbecco's modified Eagle's medium (Invitrogen, Gaithersburg, MD) supplemented with 15\% fetal bovine serum (Invitrogen, Gaithersburg, MD), 
gentamicin (50 units/mL; Invitrogen, Gaithersburg, MD), penicillin-streptomycin antibiotic mix (50 units/mL, Invitrogen, Gaithersburg, MD) and Fungizone $(5 \mu \mathrm{L} / \mathrm{mL}$, Invitrogen, Gaithersburg, $\mathrm{MD}$ ) at $36.5^{\circ} \mathrm{C}$ in the presence of $5 \% \mathrm{CO}_{2}$.

\section{Creation of MsrA over-expressing HLE cell lines.}

Over-expressing MsrA cell lines were created using the ViraPower ${ }^{\mathrm{TM}}$ Lentiviral Expression System (Invitrogen, Gaithersburg, MD). Briefly, primers were designed to amplify full length MsrA transcripts with the exception of the final 9 bps on the 3' end of the MsrA transcript encoding the last two amino acids and the stop codon. Ablation of the stop codon was necessary to fuse the over-expressed protein to a V5-epitope tag, present in the over-expression vector. This fusion allows for specific identification and differentiation of the recombinant protein from endogenous MsrA. Semi-quantitative RT-PCR was employed to amplify MsrA transcripts present in total RNA isolated from human lens epithelial tissue as described above. Products were separated by gel electrophoresis and the resulting band was excised from the gel slice using a QIAquick Gel Extraction Kit (Qiagen, Valencia, CA), cloned into the expression vector provided in the ViraPower kit and sequenced to ensure its proper orientation and integrity. 293-FT human kidney cells were transfected with the expression vector and other transfection components following the manufacturer's protocol. Virus-containing supernatants were harvested 72 hours posttransfection and used to infect HLEs. Separately prepared virus stocks and viral titers were used to create multiple over-expressing cell lines. A 
concentration of $6 \mu \mathrm{g} / \mathrm{mL}$ of Blasticidin antibiotic (Invitrogen, Gaithersburg, MD) was used to select for those cells over-expressing the MsrA gene.

\section{Confirmation of MsrA over-expression in SRA01/04 cells.}

Semi-quantitative RT-PCR, using MsrA specific primers, was used to confirm the over-expression of MsrA mRNA levels as described above. Western blots containing 15 $\mu \mathrm{g}$ of protein extract from the over-expressing cells and control cells were incubated with an anti-V5 monoclonal antibody (Invitrogen, Gaithersburg, MD) at a dilution of 1:5000 and MsrA recombinant protein was visualized as described above.

\section{siRNA-targeted gene silencing.}

Double-stranded siRNA's specific for MsrA were designed and manufactured using Qiagen’s “4-for-silencing” service (Qiagen, Valencia, CA). Multiple concentrations of the siRNA's were used to transfect HLEs using the Transmessenger Transfection Reagent kit (Qiagen, Valencia, CA) according to the manufacturer's protocol. Total RNA was isolated from the cells 24,48 and 72 hours posttransfection and semi-quantitative RT-PCR was sued to assay for reduction in MsrA mRNA levels for each of the siRNA's tested as described above. A single double-stranded siRNA construct with the following sequence: r(CCCCUGUAGCGGCCAAACAUU) and r(UGUUUGGCCGCUACAGGGGUC) was found to be the most effective in suppressing 
the transcript levels of MsrA in lens cells and was used for all of the siRNA mediated gene silencing studies.

\section{Cell viability assays using MTS reagent.}

A CellTiter $96 \mathrm{AQ}_{\text {ueous }}$ One Solution Cell Proliferation Assay (Promega, Madison, WI) kit containing the tetrazolium compound [3-(4,5-carboxymethoxyphenyl)-2-(4sulfophenyl)-2H-tetrazolium] (MTS) was used to monitor cell viability following the manufacturer's protocol. Briefly, the MTS compound is bioreduced by metabolically active cells into a colored formazan product through the action of dehydrogenase enzymes and NADPH or NADH. Cell culture medium was removed and replaced with a 1:5 dilution of the MTS reagent in phenol-free and FBS-free cell culture medium (Invitrogen, Gaithersburg, MD) and incubated in a $36.5^{\circ} \mathrm{C}$ incubator in the presence of $5 \% \mathrm{CO}_{2}$ for approximately 45 minutes or until a sufficient color change was observed. MTS color change was monitored using an ELX-800 universal plate reader (Bio-Tek Instruments, Winooski, VT) set at an absorbance reading of $492 \mathrm{~nm}$.

\section{$\mathrm{H}_{2} \mathrm{O}_{2}$ sensitivity of control, over-expressing and siRNA treated HLEs.}

HLEs were plated in 96-well plates at a density of 20,000 cells per well and treated with multiple concentrations of $\mathrm{H}_{2} \mathrm{O}_{2}$ for 24 hours. $\mathrm{H}_{2} \mathrm{O}_{2}$ treatments were analyzed in sets of four identical treatments and cell viability was monitored using MTS assays. For siRNA studies, cells were transfected with $4 \mu \mathrm{g}$ of siRNA per 500,000 cells, 
or mock transfected using all of the transfection reagents in the absence of siRNA. Mean absorbance and standard deviations for each treatment were determined. 


\section{Chapter III}

Decreased Expression of Ribosomal Proteins in Human Age-Related Cataract

WeiYan Zhang, John Hawse, QingLing Huang, Nancy Sheets, Kevin M. Miller, Joseph

Horwitz, Marc Kantorow 


\begin{abstract}
Purpose: To identify lens epithelial genes whose expression levels are altered in agerelated human cataract. Methods: Epithelia from age-related cataracts and from clear lenses were microdissected and RNA was extracted. RNAs were compared for gene expression differences by RT-PCR differential display. Transcripts exhibiting altered levels of gene expression were cloned and identified by sequencing. The expression levels of identified clones were confirmed by semi-quantitative reverse transcriptase PCR with three separately isolated RNA preparations. Specific primers were designed and used to examine the mRNA levels of other genes important for protein synthesis. Results: Numerous transcripts exhibited altered levels of gene expression. One transcript exhibiting a decreased level of expression in cataract compared to clear lenses was identified as encoding ribosomal protein L21. Three additional ribosomal proteins, L15, L13a, and L7a, also exhibited decreased expression in cataract compared to clear human lenses. By contrast, the levels of elongation factor 1 alpha 1 (EF1 $\alpha 1)$ and initiation factor 4E (eIF4E) remained unchanged. Conclusions: The results provide evidence that human age-related cataract is associated with decreased expression of L21 and other ribosomal proteins. The results suggest that modulation of protein synthesis, and/or other functions mediated by ribosomal proteins, is associated with age-related cataract.
\end{abstract}




\section{INTRODUCTION}

Identification of genes whose expression levels are altered in age-related cataract relative to clear lenses points to those protective and regulatory processes important for the maintenance of lens transparency.

In order to identify genes whose expression levels are altered in the presence of cataract, we have compared the gene expression profiles of epithelia isolated from human age-related cataract and clear lenses. The lens epithelium contains the majority of metabolic enzymes present in the lens (Bloemendal 1981; Piatigorsky 1981a; Reddy 1971b). It is the first part of the lens exposed to environmental insult (Reddan JR. 1982; Spector 1982a). Metabolic communication between the lens epithelium and the underlying fiber cells has been demonstrated (Rae et al 1996b), and damage to the lens epithelium and its enzyme systems is associated with cataract formation (Harding JJ 1984; Hightower 1995; Phelps Brown 1996; Spector 1995).

We have provided evidence that the human lens epithelium responds to the presence of age-related cataract through alterations in the levels of specific transcripts. These include decreased expression of protein phosphatase 2a regulatory subunit (Kantorow et al 1998b), increased expression of metallothionein IIa (Kantorow, Kays, Horwitz, Huang, Sun, Piatigorsky, and Carper 1998b) and increased expression of osteonectin (Kantorow, Horwitz, and Carper 1998a).

In the present study, we have used RT-PCR differential display and semiquantitative RT-PCR to provide evidence that the large ribosomal subunit proteins L21, L15, L13a and L7a exhibit decreased expression in cataract compared to normal human lenses. 
Ribosomal proteins are major constituents of ribosomes that catalyze protein synthesis in the cytoplasm (Mager 1988). The eukaryotic ribosome is composed of a large 60 S and a small 40S subunit consisting of 3 RNAs and 46 proteins and 1 RNA and 33 proteins respectively (Wool et al 1995). The catalytic functions specific to individual ribosomal proteins are largely unknown (Wool, Chan, and Gluck 1995; Wool 1996). Under normal conditions, ribosomal proteins are synthesized stoichiometrically with rRNA to produce equimolar amounts of RNA and protein. Under altered conditions, including events surrounding cellular growth and proliferation (Chester et al 1989), the expression levels of ribosomal proteins are altered. For instance, the large ribosomal subunit proteins L3, L7, L8, L10, L23a, L27a, L36a and L39 exhibit decreased expression during neuronal differentiation of human embryonic carcinoma cells as do the levels of the small ribosomal subunit proteins (Bevort and Leffers 2000). These alterations appear to be restricted to specific ribosomal proteins since some ribosomal protein levels are altered while others remain constant (Frigerio et al 1995; Laine et al 1994).

Independent alterations in ribosomal protein synthesis suggest that individual ribosomal proteins have functions beyond the simple structural makeup of the ribosome or protein synthesis. For example, $\mathrm{P} 0$ and $\mathrm{S} 3$ possess endonuclease activity suggesting that they may have DNA repair functions (Grabowski et al 1991; Kim et al 1995) and L7 can function as a co-activator of nuclear receptors (Berghofer-Hochheimer et al 1998). L7, S20, and S3a have been implicated in apoptosis (Goldstone and Lavin 1993; Naora et al 1998; Neumann and Krawinkel 1997). Altered ratios of ribosomal subunits are also associated with stage-specific tissue development (Mazuruk et al 1996). Several 
ribosomal proteins are known to be induced by agents associated with cataract including RPL13a whose synthesis is activated upon exposure to UV-irradiation and RPL7 whose synthesis is activated upon exposure to UV-irradiation, heat-shock or carcinogens (Ben Ishai et al 1990).

The present data provide evidence that the levels of specific ribosomal transcripts are decreased in age-related human cataract. Although we cannot distinguish that decreased ribosomal protein expression is a consequence of cataract or a response of the lens to cataract, the results suggest that regulation of protein synthesis and/or other functions mediated by ribosomes are associated with age-related cataract. 


\section{RESULTS}

\section{Differential display detects altered gene expression between cataract and clear human lens epithelia.}

Differential display was performed on RNAs isolated from 30 pooled cataracts and 15 pooled normal human lens epithelia using two different primer sets. Fig. 1A is the differential display profile obtained with primer set 1 and Fig. $1 \mathrm{~B}$ is the differential display profile obtained using primer set 2. Three bands (Fig. 1, A, B and C) were excised from the differential display gel and successfully re-amplified. One band exhibited decreased expression between cataract and clear lenses by differential display (Fig. 1B, band C). This band yielded an approximately $200 \mathrm{bp}$ re-amplification product. The two other bands (Fig. 1A, bands A and B) exhibited equal levels between cataract and clear epithelia. These were selected as controls and yielded approximately $200 \mathrm{bp}$ reamplification products.

Cloning and sequencing of these transcripts revealed that band $\mathrm{C}$ was identical with base pairs +168 through +352 from the start of translation of the reported cDNA sequence for ribosomal protein L21 with the exception of three mismatches (Fig. 2A). Control bands A and B were identical in sequence to $+1108-1239$ from the start of translation of the reported cDNA sequence for glycoprotein 130 (gp130) mRNA (Fig. 2B). It is uncertain whether the mismatches detected for $\mathrm{L} 21$ represent actual differences from the reported sequence or PCR incorporation errors. 


\section{Confirmation of ribosomal protein $\mathrm{L} 21$ and gp130 transcript levels between cataract and clear lens epithelia.}

Decreased expression of ribosomal protein L21 between epithelia isolated from cataractous and normal lenses was confirmed by semi-quantitative RT-PCR using separately isolated cataract and normal RNA samples prepared from an additional 20 cataract and 8 normal lenses. gp130 and $\beta$-actin transcripts were simultaneously examined as controls. The RT-PCR primers for RPL21 amplification (Table 1) were designed to produce a 504bp product and were complementary to sense nucleotides +7 through +26 and antisense nucleotides +534 through +511 of the L21 cDNA sequence from the start of translation. The RT-PCR primers for gp130 amplification (Table 1) were complementary to sense nucleotides +2113 through +2137 and antisense nucleotides +2583 through +2559 of the gp 130 cDNA sequence from the start of translation.

Consistent with the differential display results (Fig. 1), L21 expression was almost entirely restricted to clear lens epithelium (Fig. 3B, compare lanes 3 and 7 to 4 and 8). As control, gp130 was detected at equal levels between cataract and normal epithelia (Fig. 3B, compare lanes 1 and 5 to 2 and 6). As a further control, the levels of $\beta$-actin transcript were identical between cataract and normal epithelia (Fig. 3A, compare lanes 1 and 2).

As a further confirmation, the differences in L21 expression between cataract and clear lenses were examined by monitoring $\left[\alpha^{33} \mathrm{P}\right]$-ATP incorporation into RT-PCR products using a third set of cataract and clear lens RNAs prepared from an additional 25 
cataract and 10 clear lenses. Consistent with the differential display results (Fig. 1), and the previous RT-PCR results (Fig. 3), L21 expression was significantly decreased between cataract and clear lenses (Fig. 4A, compare lanes 1 and 3 to 2 and 4). As control, the levels of gp130 or GAPDH control transcripts were the same between cataract and clear lenses (Fig. 4, B and C). Based on incorporated radioactivity, it is estimated that L21 levels are decreased 3- to 4-fold between cataract and clear human lenses.

\section{Spatial expression of ribosomal protein L21 mRNA in the clear human lens.}

In the differential display and semi-quantitative RT-PCR procedures, approximately $6-8 \mathrm{~mm}$ portions of central clear lens epithelia were compared with approximately $5-6 \mathrm{~mm}$ portions of central cataract epithelia. To be certain that decreased expression of L21 in cataract verses clear lenses was not a consequence of spatial differences in L21 expression, 4 clear lenses were microdissected into whole (7-9mm), central (4-6mm), and peripheral epithelium (2-3 mm) portions and examined for L21 expression by RT-PCR (Fig. 5). L21 expression was also examined in whole lens minus the epithelium and in cortical lens fibers alone (Fig. 5).

Approximately equal levels of L21 were detected between whole epithelium (Fig. 5A, WE), central epithelium (Fig. 5A, CE) and peripheral epithelium (Fig. 5A, PE), indicating that L21 expression differences did not result from spatial expression differences. Slightly more RPL21 was detected in whole lens epithelia (Fig. 5A, WE) than in central or peripheral lens epithelium (compare lanes 1 and 2 to 3). More L21 
transcript was detected in whole lens minus epithelium (Fig. 5A, WF) than in cortical fibers alone (Fig. 5A, CF) (compare lanes 4 and 5). As control, equal levels of GAPDH were detected in all samples (Fig. 5B, compare lanes 6-10).

\section{Expression of other ribosomal proteins in cataract verses normal human lenses.}

To determine if the levels of other ribosomal proteins in addition to L21 were decreased between cataract and clear lenses, the levels of three other large ribosomal subunit proteins L15, L13a and L7a were examined using RNAs prepared from an additional 15 cataract and 8 normal human lens epithelia (Fig. 6A). The levels of the elongation factor EF1 $\alpha 1$ and the initiation factor eIF4E were also examined (Fig. 6B). The level of GAPDH was examined as a control (Fig. 6C).

All three ribosomal proteins exhibited decreased expression in cataract compared to clear human lenses (Fig. 6A, lanes 1-12). RPL15 and RPL13a exhibited the greatest differences in expression (Fig. 6A, compare lanes 1-4 to 5 and 6). By contrast, the levels of EF1 $\alpha 1$ and eIF4E transcripts were unaltered between cataract and clear lenses (Fig. 6B, lanes 1-4). As control, GAPDH transcript levels were identical between cataract and clear lenses (Fig. 6C, compare lanes 1 and 3). 
Table 1. Primers used for RT-PCR

\begin{tabular}{|c|c|c|c|}
\hline Gene & Accession \# & Sequence & Annealing Temperature \\
\hline L21-1 & XM_040643 & CGCCAAAATGACGAACACAA & $55 \mathrm{C}$ \\
\hline L21 - & XM_040643 & GTAGCCCAGAGGTCCTTTATTTTT & $55 \mathrm{C}$ \\
\hline gp130-1 & XM_042068 & GCCATAGTCGTGCCTGTTTGCTTAG & $55 \mathrm{C}$ \\
\hline gp130-2 & XM_042068 & GACTTGGACTGACGGAACTTGGTGT & $55 \mathrm{C}$ \\
\hline L15-1 & NM_002948 & TGTCATCATGCGCTTTCTTCTG & $58 \mathrm{C}$ \\
\hline L15-2 & NM 002948 & CCCTGTGCTTGTGGACTGGTT & $58 \mathrm{C}$ \\
\hline L13a-1 & XM_027885 & GTATGCTGCCCCACAAAACCA & $58 \mathrm{C}$ \\
\hline L13a-2 & XM_027885 & CAACGCATGAGGAATTAACAGTCTT & $58 \mathrm{C}$ \\
\hline L7a-1 & XM_035105 & ATTTTGGCATTGGACAGGACATC & $58 \mathrm{C}$ \\
\hline L7a-2 & XM_035105 & GGACCCCCATTTTACGACACAG & $58 \mathrm{C}$ \\
\hline eIF4E-1 & XM_017925 & CCCCCGACTACAGAAGAGGAGAA & $55 \mathrm{C}$ \\
\hline eIF4E-2 & XM_017925 & AACAGCGCCACATACATCATCACT & $55 \mathrm{C}$ \\
\hline EF1 $\alpha 1-1$ & XM_029230 & TTTGCCGCCAGAACACAG & $55 \mathrm{C}$ \\
\hline EF1 $\alpha 1-2$ & XM 029230 & CCAGCAGCAACAATCAGGAC & $55 \mathrm{C}$ \\
\hline GAPDH-1 & BC004319 & TGTTCCAATATGATTCCACCC & $52 \mathrm{C}$ \\
\hline GAPDH-2 & BC004319 & CCCACACCCTCTCACTGTA & $52 \mathrm{C}$ \\
\hline$\beta-\alpha \chi \tau \imath \nu-1$ & XM_037239 & TCATGAAGTGTGACGTTGACATCCGT & $60 \mathrm{C}$ \\
\hline$\beta-\alpha \chi \tau \imath v-2$ & XM_037239 & CCTAGAAGCATTTGCGGTGCACGATG & $60 \mathrm{C}$ \\
\hline
\end{tabular}


Figure 1. RT-PCR differential display profile of cataractous $(\mathrm{C})$ and clear $(\mathrm{N})$ epithelia. A: The autoradiogram obtained using primer set 1. B: The autoradiogram obtained using primer set 2. Arrows indicate bands chosen for further analysis. Approximate sizes in base pairs (bp) are indicated. 
A.

PRIMER SET 1

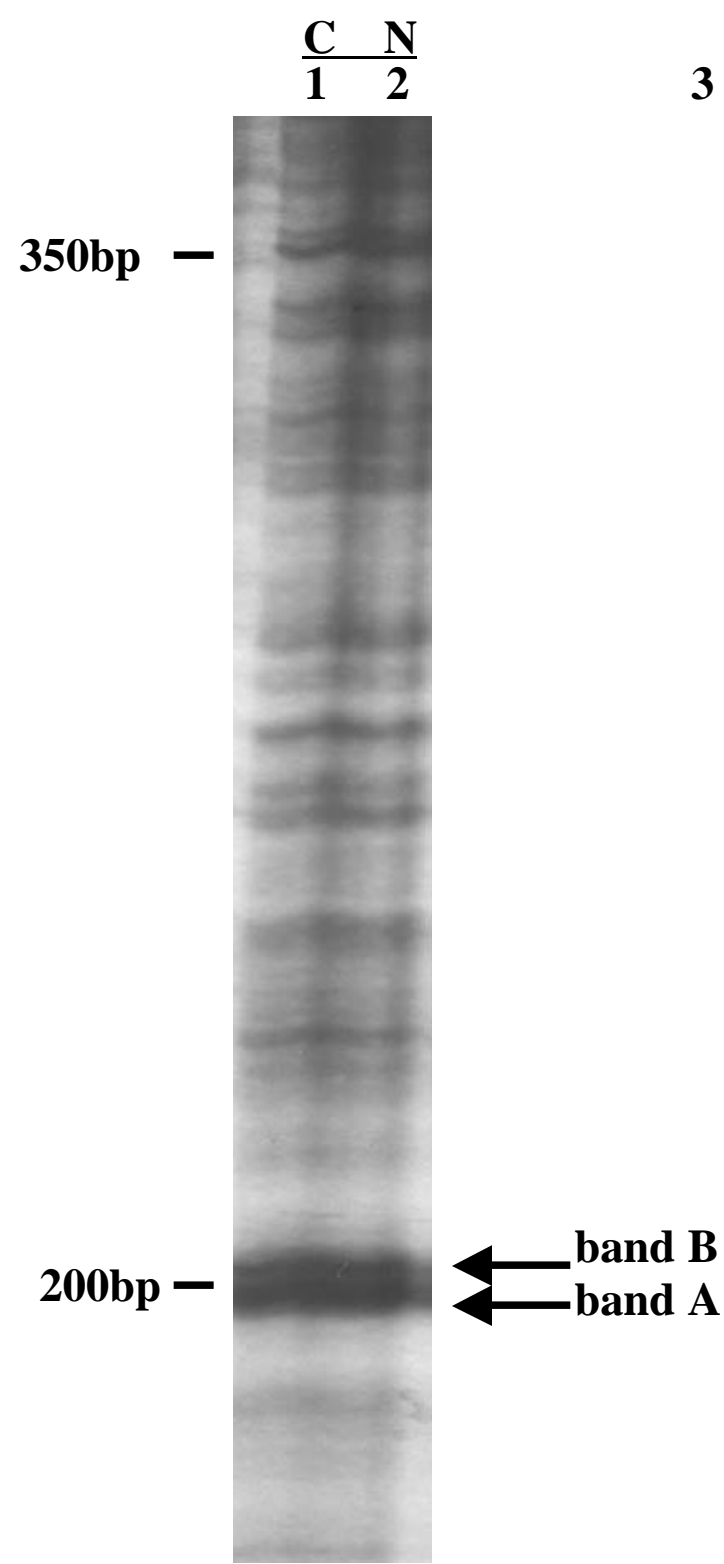

B.

\section{PRIMER SET 2}

3

400bp -

C N

4

200bp -

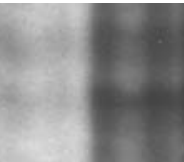

band C 
Figure 2. Sequence alignment of ribosomal protein L21 and glycoprotein 130 (gp130) with reported sequences. A: Differential display band C (middle) aligned with the reported sequence for ribosomal protein L21 (bottom). B: Differential display bands A and B aligned with the reported sequence for gp130. Top sequences indicate the differences between obtained and reported sequences. 
A.

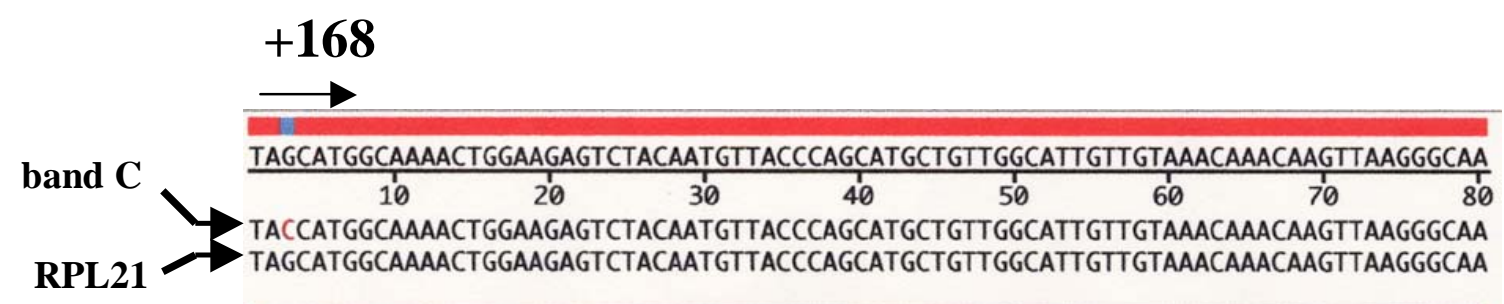

GATTCTTGCCAAGAGAATTAATGTGCGTATTGAGCACATTAAGCACTCTAAGAGCCGAGATAGCTTCCTGAAACGTGTGA

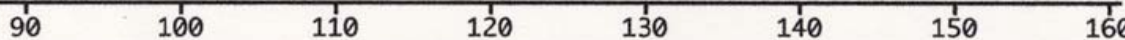
GATTCTTGCCAAGAGAATTAATGTGCGTATTGAGCACATTAAGCACTCTAAGAGCCGAGATAGCTTCCTGAAACGTGTGA GATTCTTGCCAAGAGAATTAATGTGCGTATTGGGCACATTAAGCACTCTAAGAGCCGAGATAGCTTCCTGAAACGTGTGA

$\frac{\text { AGGAAAATGATCAGAAAAAGAAAG }}{170} 180$
AGGAAAATGATCAGAAAAAGAAAG
AGGAAAATGATCAAAAAAAAAAAG

$+352$

B.

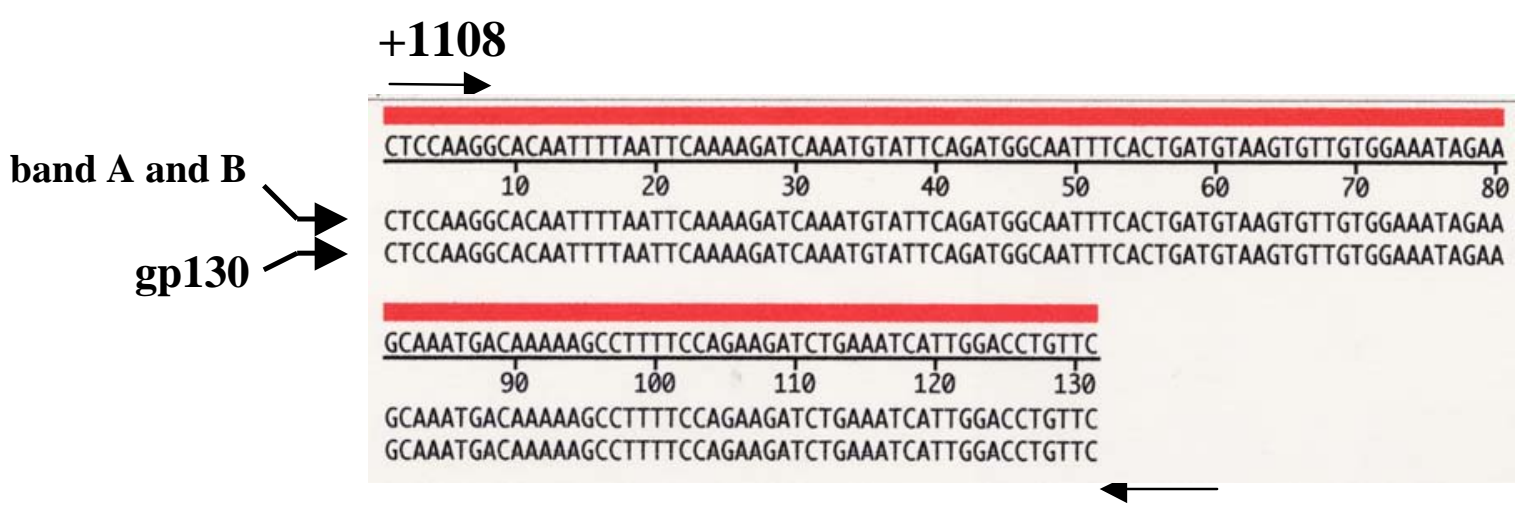

$+1239$ 
Figure 3. Confirmation of ribosomal protein L21 and glycoprotein 130 (gp130) mRNA levels between pooled cataract $(\mathrm{C})$ and normal clear $(\mathrm{N})$ lens epithelia. Ethidium bromide stained gel showing the transcript levels detected by RT-PCR using indicated amounts of cataract (C) and clear lens (N) RNA. A: Ethidium bromide stained gel showing the levels of $\beta$-actin control. B: Ethidium bromide stained gel showing the levels of L21 and gp130 products. PCR cycles are indicated. 


\begin{tabular}{llr} 
A. & \multicolumn{2}{c}{$\beta$-actin } \\
& C & N \\
RNA(ng) & 10 & 10 \\
& 1 & 2 \\
cycles & - & -
\end{tabular}

\begin{tabular}{crrrrr} 
B. & \multicolumn{2}{c}{ gp130 } & \multicolumn{2}{c}{ RPL21 } \\
& C & N & C & N \\
RNA(ng) & 10 & 10 & 10 & 10 \\
cycles & 1 & 2 & 3 & 4 \\
\hline 21 & & & & - \\
& & & & & \\
& & & & & \\
& 5 & 6 & & 7 & 8 \\
24 & - & & & &
\end{tabular}


Figure 4. Re-confirmation of ribosomal protein L21 and glycoprotein 130 (gp130) transcript levels between cataract and normal clear lens epithelia. Ethidium bromide stained gels showing the relative transcript levels of L21 (A), gp130 (B), and GAPDH (C), detected by RT-PCR using indicated amounts of cataract (C) and normal clear (N) lens epithelia. L21 products were further examined by monitoring radioactive incorporation (cpms, indicated). PCR cycles are also indicated. 
A.

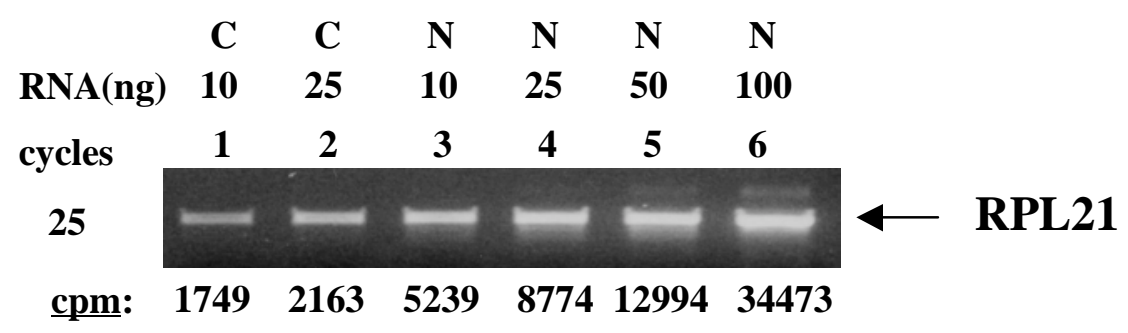

B.

$\begin{array}{lccccc} & \text { C } & \text { N } & \text { N } & \text { N } & \text { N } \\ \text { RNA(ng) } & 25 & 10 & 25 & 100 & 150\end{array}$

$\begin{array}{llllll}\text { cycles } & 1 & 2 & 3 & 4 & 5\end{array}$

25

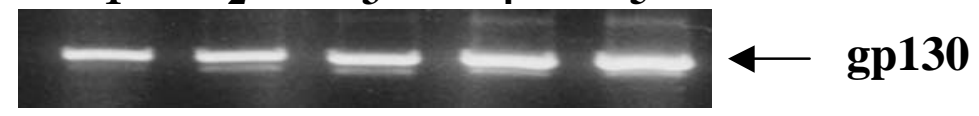

C.

$\begin{array}{lcccccc} & \text { C } & \text { N } & \text { N } & \text { N } & \text { N } & \text { N } \\ \operatorname{RNA}(n g) & 10 & 3 & 5 & 10 & 15 & 20 \\ \operatorname{cycles} & 1 & 2 & 3 & 4 & 5 & 6 \\ \quad 25 & - & & & & & \end{array}$


Figure 5. Spatial expression of ribosomal protein L21 in microdissected lens portions. Ethidium bromide stained gel showing the levels of L21 detected by RT-PCR using indicated amounts of RNA from whole epithelium (WE), central epithelium (CE), peripheral epithelium (PE), lens minus the epithelium (WF) and cortical fibers (CF). 


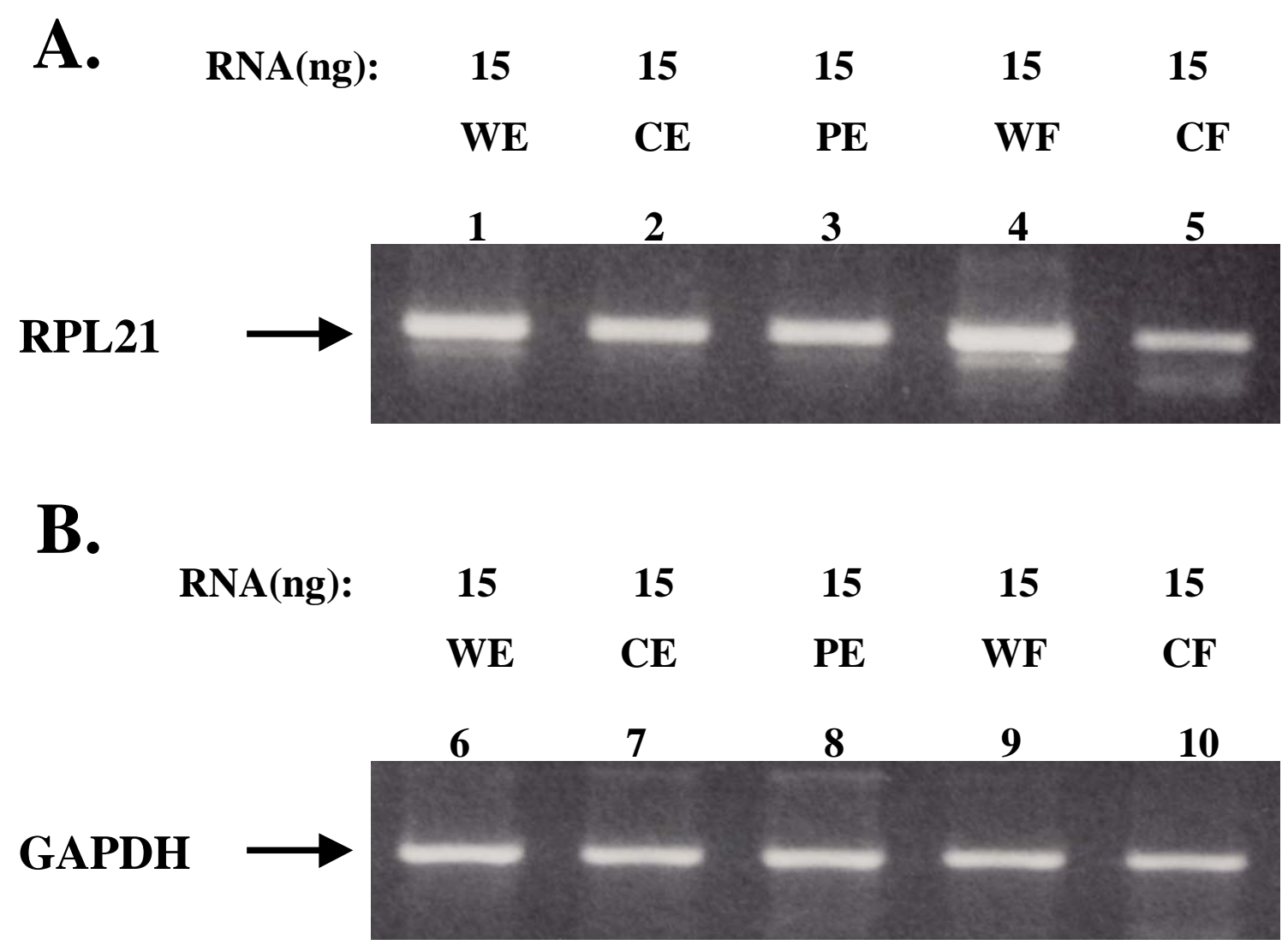


Figure 6. Expression of other ribosomal proteins in cataractous $(\mathrm{C})$ and normal clear $(\mathrm{N})$ lens epithelia. Ethidium bromide-stained gels showing the relative levels of (A) L15, L13a, and L7a; (B) EF1 $\alpha 1$ and eIF4E; and (C) GAPDH control transcript detected by RT-PCR. 
A.

RPL15 RPL13a RPL7a

RNA(ng): $\quad \begin{array}{lllllll}30 & 30 & 30 & 30 & 30 & 30\end{array}$

$\begin{array}{llllll}C & \mathbf{N} & \mathbf{C} & \mathbf{N} & \mathbf{C} & \mathbf{N}\end{array}$

$\begin{array}{lllllll}1 & 2 & 3 & 4 & 5 & 6 & \text { cycles } \\ & & & & & & \\ & & - & - & - & - & 20\end{array}$

$\begin{array}{llllll}7 & 8 & 9 & 10 & 11 & 12\end{array}$

22
B.

\begin{tabular}{lccccc} 
& \multicolumn{2}{c}{ EF1 $\alpha 1$} & \multicolumn{2}{c}{ eIF4E } & \\
RNA(ng): & 50 & 50 & 50 & 50 & \\
& C & N & C & N & \\
& 1 & 2 & 3 & 4 & cycles \\
& & & & & 25 \\
& & & & & \\
& & & & & \\
C. & & & & & \\
& & GAPDH & & \\
RNA(ng): & 10 & 4 & 10 & 15 \\
& C & N & N & N & \\
& 1 & 2 & 3 & 4 & \\
& & - & -6 & 25
\end{tabular}




\section{DISCUSSION}

In the present study RT-PCR differential display was used to detect decreased expression of ribosomal protein L21 between age-related cataract and clear human lenses. This result was confirmed by semi-quantitative RT-PCR using three separately isolated cataract and clear lens epithelia RNA preparations. Based on incorporation of radioactivity, L21 expression is approximately 4-fold decreased between cataract and clear lenses.

Decreased L21 expression between cataract and clear lenses is not a consequence of spatial differences between different regions of the lens epithelium since identical levels of L21 were detected by RT-PCR using central verses peripheral lens epithelial RNA.

It is unlikely that differences in L21 expression are a consequence of differences between post-mortem times since all samples were stored on ice during transport and no differences in the levels of GAPDH or $\beta$ B2-crystallin transcripts could be detected between lens epithelia stored for 1 hour or 36 hours at $4^{\circ} \mathrm{C}$ (data not shown). Moreover, the levels of the vast majority of transcripts detected between cataract and clear lenses in the present study by both differential display and RT-PCR, including GAPDH, GP130, EF1 $\alpha 1$ and eIF4E, exhibited identical levels between cataract and normal lenses. If postmortem times were a factor, it is likely that large differences in the levels of all transcripts would be detected.

Every attempt was made to ensure the detection of cataract-specific differences in the present study. However, we cannot rule out the possibility that changes in L21 
expression could also be related to differences in age between normal and cataract lenses (averaging 60 and 71 years, respectively), or differences in medical histories, or racial/regional characteristics of individual donors. The human population is diverse and each individual has a unique life history, making it extremely difficult, if not impossible, to obtain exact controls. We are confident that our results are cataract-specific since identical levels of gene expression were detected in three separately isolated populations of normal and cataract lenses which would be expected to compensate for individual variability. However, we cannot eliminate the possibility of these factors having some influence on our results or their interpretation.

The onset of cataract is gradual and some of the normal lenses used in the present study are likely to contain undetected opacities despite careful microscopic examination performed to reduce this possibility. The presence of cataract lenses mixed with the normal lens population is likely to have the effect of reducing the magnitude of gene expression differences detected in the present study, but is not likely to change the overall trends in gene expression established by the present data.

The lenses examined in this study were mostly mixed cataracts with about one fifth nuclear cataracts and a smaller percentage of cortical and posterior sub-capsular cataracts. Thus, no direct correlation between decreased expression of L21 and cataracttype can be made from the present study. In preliminary experiments, no difference in the levels of L21 was detected in individual cataracts. Further studies with large numbers of individual lenses will be needed to establish a relationship between L21 expression and specific cataract phenotypes. 
L21 is not the only ribosomal protein exhibiting decreased expression between cataract and clear human lenses. Decreased expression of L15, L13a and, to a lesser extent, L7a was also detected. In contrast to the ribosomal proteins, two other proteins involved in protein synthesis, elongation factor EF1 $\alpha 1$ and initiation factor eIF4E exhibited identical levels of expression between cataract and normal lenses. Unchanged levels of EF $1 \alpha 1$ and initiation factor eIF4E is not a surprising result since previous reports indicated that translational control (Chen et al 2000) and gene amplification (Sorrells et al 1998) were responsible for altered levels of these proteins respectively.

Decreased expression of ribosomal proteins is likely to result in decreased lens protein synthesis. Protein synthesis is dependent on the relative levels of ribosomal proteins, ribosomal RNA, initiation factors and elongation factors (Wool, Chan, and Gluck 1995). Since about $98 \%$ of total RNA is ribosomal RNA, and measurements performed in the present study were equalized to total RNA, the present data indicate that the ratio of ribosomal RNA to total RNA is decreased in cataract compared to normal lenses. This is likely to result in decreased translation of lens proteins through decreased availability of ribosomal subunits.

It is not possible to distinguish whether decreased expression of ribosomal transcripts is a consequence of cataract or a specific response of the lens to the presence of cataract and further studies will be needed to elucidate the mechanisms underlying this phenomenon. Regardless of whether decreased ribosomal transcript expression is a consequence of cataract, or a response of the lens to the presence of cataract, the present results suggest that decreased translation of proteins is associated with age-related cataract and this hypothesis is supported by other studies that have demonstrated 
decreased protein synthesis in association with lens insult (Andley et al 1990; Garadi et al 1984; Mazuruk, Schoen, Chader, Iwata, and Rodriguez 1996) and cataract (Duncan and Marcantonio 1982; Haloui et al 1990; Kuck 1990).

In addition to having a direct role in protein synthesis, several ribosomal proteins identified in the present study have additional functions. L13 has been proposed to act as a tumor suppressor (Frigerio, Berthezene, Garrido, Ortiz, Barthellemy, Vasseur, Sastre, Seleznieff, Dagorn, and Iovanna 1995) and L7 can function as a co-regulator of nuclear receptors (Hightower 1995). L7 has also been implicated in apoptotic pathways (Goldstone and Lavin 1993; Naora, Takai, Adachi, and Naora 1998; Neumann and Krawinkel 1997) and is induced by UV-light and heat-shock (Ben Ishai, Scharf, Sharon, and Kapten 1990). Many of these functions are also associated with cataract, and it is interesting to speculate that they may be related to the decreased expression of ribosomal transcripts identified in the present study.

Regardless of the function for decreased expression of ribosomal proteins in cataract, the present report supports the hypothesis that age-related cataract is associated with changes in the expression levels of specific genes. The data also suggest that changes in protein synthesis and/or other pathways mediated by ribosomal proteins may play important roles in lens transparency. 


\section{Chapter IV}

Identification and Functional Clustering of Global Gene Expression Differences between Human Age-Related Cataract and Clear Lenses

John R. Hawse, James F. Hejtmancik, Quingling Huang, Nancy L. Sheets, Douglas A. Hosack, Richard A. Lempicki, Joseph Horwitz, Marc Kantorow 


\begin{abstract}
Purpose: Age-related cataract is a multi-factorial disease with a poorly understood etiology. Numerous studies provide evidence that the human eye lens has evolved specific regulatory and protective systems to ameliorate lens damage associated with cataract. Other studies suggest that the presence of cataract is associated with the altered expression of specific genes including, metallothionein IIa, osteonectin, transglutaminase 2, betaig-h3, multiple ribosomal proteins, ADAM9 and protein phosphatase 2A. Here, we sought to identify further gene expression changes that are associated with cataract and to cluster the identified genes into specific biological pathways. Methods: Oligonucleotide microarray hybridization was used to analyze the full complement of gene expression differences between lens epithelia isolated from human age-related cataract relative to clear lenses. The expression levels of a subset of the identified genes were further evaluated by semi-quantitative RT-PCR. The identified genes were functionally clustered into specific functional categories and the probability of over-representation of each category was determined using the computer program
\end{abstract} EASE. Results: 412 transcripts were detected to be increased and 919 transcripts were detected to be decreased by 2-fold or more in lens epithelia isolated from age-related cataract relative to clear lenses. Of these, 74 were increased and 241 were decreased at the 5-fold level or greater. Seventeen genes selected for further confirmation exhibited similar trends in expression when examined by RT-PCR using both the original and separately prepared clear and cataract RNA populations. Functional clustering of the identified genes using the EASE bioinformatics software package revealed that among others, transcripts increased in cataract are associated with transcriptional control, 
chromosomal organization, ionic and cytoplasmic transport and extracellular matrix components while transcripts decreased in cataract are associated with protein synthesis, defense against oxidative stress, heat-shock/chaperone activity, structural components of the lens and cell cycle control. Conclusions: These data suggest that cataract is associated with multiple previously identified and novel changes in lens epithelial gene expression and they point to numerous pathways likely to play important roles in lens protection, maintenance and age-related cataract. 


\section{INTRODUCTION}

The role of the eye lens is to focus incoming light onto the retina where visual information is then processed and transmitted to the brain. The lens is an excellent model for the study of age-related diseases since it has no blood supply, contains some of the oldest cells in the body, grows throughout life and is exposed to multiple environmental insults including toxic metals and UV-light which can result in oxidative stress (Phelps Brown 1996). Oxidative stress, combined with aging of the lens and consequential lens cell damage, is believed to contribute to age-related cataract formation, an opacity of the lens that results in blindness (Phelps Brown 1996). Cataract is a major health issue worldwide as it is the leading cause of world blindness and surgical removal of the lens is the only known treatment. Cataract is an enormous economic burden accounting for $12 \%$ of all Medicare expenses in the United States each year and with an aging American population cataract is, and will continue to be, a major economic and quality of life concern.

Despite the large number of studies documenting the biochemical and metabolic changes in the lens associated with age-related cataract, little is known about the changes in gene expression associated with this disease. To identify these changes we have focused on the lens epithelium since this monolayer of cells is essential for the growth, differentiation and homeostasis of the entire organ (Bloemendal 1981; Piatigorsky 1981a). The lens epithelium contains the highest levels of enzymes and transport systems in the lens (Reddan JR. 1982; Reddy 1971b; Spector 1982a) and is the first part of the lens exposed to environmental insults (Reddan JR. 1982; Spector 1982a). Multiple 
studies suggest that the lens epithelium is capable of communicating with the underlying fiber cells (Rae, Bartling, Rae, and Mathias 1996b) and direct damage to the lens epithelium and its enzyme systems is known to result in cataract formation (Harding JJ 1984; Hightower 1995; Phelps Brown 1996; Spector 1995). Importantly, the majority of transcription occurs in the epithelial cells of the lens, and therefore these cells make up the majority of lens cells capable of responding to environmental insults and/or the presence of cataract through altered gene expression. Since the lens epithelium is composed of a single cell-type it represents an ideal model for gene expression studies.

Although a multitude of lens culture studies have documented changes in the expression of numerous genes in response to $\mathrm{H}_{2} \mathrm{O}_{2}$, toxic metals, $\mathrm{UV}$-light and other stresses, and multiple studies have examined changes in gene expression in animal models of cataract, the full complement of gene expression differences that occur in the lens epithelial cells of human age-related cataract is not known. Previous studies have used RT-PCR differential display and other techniques to identify differences in gene expression between human lens epithelial cells isolated from cataract relative to clear lenses. For instance, metallothionein IIa (Kantorow, Kays, Horwitz, Huang, Sun, Piatigorsky, and Carper 1998b), osteonectin, also known as SPARC (Kantorow, Horwitz, and Carper 1998a), transglutaminase 2 (Wan et al 2002), and betaig-h3 (Lee et al 2000), are reported to be increased in cataract relative to clear lenses while multiple ribosomal proteins (Zhang et al 2002), ADAM9 (Lim et al 2002) and protein phosphatase 2A (Kantorow, Kays, Horwitz, Huang, Sun, Piatigorsky, and Carper 1998b) are reported to be decreased in cataract relative to clear lenses. 
While these studies have provided important insight into the roles of individual gene expression changes in age-related cataract, information concerning individual gene expression changes is not adequate to reveal related clusters of genes whose identities are necessary to elucidate the biological pathways that are altered in age-related cataract. Although recent studies have examined the global changes in gene expression that occur in cultured human lens epithelial cells exposed to $\mathrm{H}_{2} \mathrm{O}_{2}$, a stress associated with cataract (Goswami et al 2003; Spector et al 2002), to date, no comprehensive study has documented the global gene expression changes occurring between human age-related cataract and clear lenses or reported the functional clustering of age-related cataractspecific genes. This information is necessary to identify those biological pathways altered in age-related cataract and is essential towards understanding the molecular basis for this disease. Despite the difficulty in obtaining sufficient numbers of human cataracts and clear lenses for this type of large-scale analysis, it is important that these studies be conducted with actual human lens epithelia since no tissue culture or animal model system can mimic the unique life history, physiology and genetic responses of the human lens.

Here, we have used oligonucleotide microarrays to compare the global gene expression profiles between pooled age-matched human lens epithelia isolated from cataract and clear lenses. We demonstrate that more than 1300 of the 22,215 genes surveyed have expression levels that differ by 2 -fold or more in cataracts compared to clear lenses. Of these, 74 genes are increased and 241 genes are decreased in cataract relative to clear lenses at the level of 5-fold or greater. Functional clustering and overrepresentation analysis of the identified genes revealed that multiple biological pathways 
are significantly altered upon cataract formation including chaperones, oxidative stress, protein synthesis and ion transport pathways. These data provide the basis for designing functional experiments to examine the roles of the identified genes in lens maintenance and protection and they provide insight into those mechanisms that may be important for the development of, and defense against, age-related cataract. 


\section{RESULTS}

\section{Oligonucleotide Microarray Analysis.}

Analysis of gene expression differences between pooled age-matched cataract and clear lenses was conducted using Affymetrix HG_U133A microarrays as described in chapter II. In this analysis, only one hybridization was conducted for each RNA population due to the extremely large number of human lens epithelia required for this type of analysis and the limited availability of these tissues. Comparison of the gene expression data for 22,215 genes represented by 222,830 separate probe sets, each probe set containing 10 perfect match and 101 base pair mismatch probe sequences, between cataract and clear lens samples, identified 412 transcripts that were increased (Fig. 1) and 919 transcripts that were decreased (Fig. 2) by 2-fold or greater in cataract compared to clear lenses. Of the genes that exhibited increased expression in cataracts, $82 \%$ of them were increased by $2-5$-fold, $13 \%$ by $5-9$-fold, $3 \%$ by $9-15$-fold, and $2 \%$ by greater than 15 -fold (Fig. 1). Of the genes that exhibited decreased expression in cataracts, $74 \%$ of them fell into the $2-5$-fold range, $15 \%$ in the 5 -9-fold range, $7 \%$ in the $9-15$-fold range and $4 \%$ in the 15 -fold and greater range (Fig. 2). Of the identified genes, 74 exhibited increased expression, of which 24 are ESTs or unknown gene products, and 241 exhibited decreased expression, of which 25 are ESTs or unknown gene products, at the 5-fold or greater level in cataract relative to clear lenses. These genes and their relative expression levels, intensity values and accession numbers are listed in Table 2. 


\section{Semi-Quantitative RT-PCR Confirmations.}

In order to confirm the accuracy of the microarray data, semi-quantitative RTPCR was conducted with the original RNA samples used for the microarray experiments and 2 other sets of separately prepared cataract and clear lens RNA samples. Thirteen genes that were either increased or decreased by 2-fold or greater in cataracts were first examined using the same RNA samples that were used for the microarray studies. These included $\mathrm{Na}^{+} / \mathrm{H}^{+}$exchanger isoform II (6.50-fold), serine/threonine protein kinase (3.73fold), $\mathrm{Na}^{+} / \mathrm{K}^{+}$ATPase (8.00-fold), secreted apoptosis related protein 2 (6.06-fold), pleiotrophin (7.46-fold) and E3-ubiquitin ligase (4.59-fold) which all exhibited increased expression in cataracts according to the microarray data and heat shock protein $27-1$ (128-fold), $\alpha$ A-crystallin (22.63-fold), ribosomal protein large subunit 13a (2.64-fold), metallothionein IF (5.66-fold), metallothionein IH (3.48-fold), metallothionein IG (3.73fold) and glutathione peroxidase-1 (4.92-fold) which all exhibited decreased expression in cataracts according to the microarray data.

Eleven out of the 13 genes examined followed the same trends in gene expression as demonstrated by the microarray study (Fig. 3A) using the original RNA samples including $\mathrm{Na}^{+} / \mathrm{H}^{+}$exchanger isoform II, secreted apoptosis related protein 2, pleiotrophin, E3-ubiquitin ligase, heat shock protein 27-1, $\alpha$ A-crystallin, ribosomal protein large subunit 13a, metallothionein IF, metallothionein IH, metallothionein IG and glutathione peroxidase-1. The 2 genes that did not follow the same trends in gene expression as demonstrated by the microarray data were serine/threonine protein kinase and $\mathrm{Na}^{+} / \mathrm{K}^{+}$ ATPase (Fig. 3A). 
A second sample of RNA was prepared from an additional 50 cataract and 10 agematched clear lenses. Due to the limited amount of RNA recovered from the second population of cataracts, 7 out of the 13 above-mentioned genes, including 2 that did not confirm the microarray data using the first samples of RNA, were re-examined using the new samples of RNA. Of these, 5 of the 7 genes exhibited similar trends as detected in the microarray analysis including $\mathrm{Na}^{+} / \mathrm{H}^{+}$exchanger isoform II, pleiotrophin, metallothionein IF, serine/threonine protein kinase and $\mathrm{Na}^{+} / \mathrm{K}^{+}$ATPase (Fig. 3B). The 2 genes that did not reconfirm in the second sample of RNA were $\alpha$ A-crystallin and ribosomal protein large subunit 13a.

In order to further confirm the trends exhibited by the microarray study and to demonstrate that the PCR cycles used are within the linear range, we examined two particular genes of interest in a third sample of RNA prepared from another 50 cataract and 10 age-matched clear lenses. Consistent with the microarray data, both Hsp 27 form 1 and 2 exhibited decreased expression in cataract relative to clear lenses using a fixed amount of cataract RNA (50 ng) and 5 different amounts of clear lens RNA (5, 10, 30, 50 and $100 \mathrm{ng}$ ) (Fig. 4). Heat shock protein 27 form 1 was decreased in cataract relative to clear lenses by approximately 10 -fold while heat shock protein 27 form 2 was decreased in cataract by approximately 2 -fold. Using this same sample of RNA we examined the expression levels of 3 genes (catalase, MTF- 1 and $\alpha \mathrm{B}-$ crystallin) that were unaltered between cataracts and clear lenses according to the microarray data as a further control. All 3 of these genes exhibited identical expression levels between cataract and normal lens epithelia as predicted by the microarray analysis (Fig. 4). 
Densitometric gel scanning of all of the semi-quantitative RT-PCR products described in figures 3 and 4 was also conducted to further evaluate the data (Table 3 ). Although all of the calculated fold changes do not exactly match those detected by the microarray hybridization data, they importantly follow the same general trends in gene expression revealed by the microarray data. These combined confirmations suggest that the gene expression trends revealed by microarray analysis are approximately $84 \%$ accurate.

\section{Functional Clustering Analysis of Differentially Expressed Transcripts.}

The set of genes that exhibited either increased or decreased expression levels of 2-fold or greater was analyzed for significant enrichment with respect to various categories of gene function using the EASE bioinformatics package (http://david.niaid.nih.gov/david/ease.htm). Categories enriched within the mRNAs increased or decreased at the 2-fold or greater level with an EASE score of less than 0.05 are shown in Figures 5-8 and are listed in Table 4. Because many genes have more than one function and are involved in various pathways, many of the identified genes appear in multiple categories.

Statistically significant trends in biological processes (Fig. 5) and molecular functions (Fig. 6) with increased gene expression in cataract were chromosome organization, nuclear organization, transcription/DNA-dependent, transcription, nucleic acid metabolism, nucleic acid binding, ligand binding or carrier and DNA binding. Statistically significant trends in biological processes (Fig. 7) and molecular functions 
(Fig. 8) with decreased gene expression in cataract were RNA splicing, protein biosynthesis, protein synthesis elongation, protein synthesis initiation, macromolecule biosynthesis, amine biosynthesis, peroxidase reaction, microtubule-based process, organelle organization, cytoskeleton organization, temperature response, heat shock response, vision, response to external stimulus, U6 snRNA binding, pre-mRNA splicing factor, mRNA binding, proteasome endopeptidase, translation factor, selenium binding, alcohol dehydrogenase, heat shock protein, oxidoreductase, glutathione peroxidase, chaperone, structural constituents of lens and structural molecule. Specific examples of the genes included in each category are summarized in Table 4. 
Table 1. Primers Used for RT-PCR

\begin{tabular}{|c|c|c|c|c|}
\hline Gene & Abbreviation & Primer Sequence & $\begin{array}{c}\text { Annealing } \\
\text { Temperature }\end{array}$ & Accession No. \\
\hline Hsp27-1 & Hsp27-1 & CGCGCTCAGCCGGCAACTCAG & 64 & XM_055937 \\
\hline Hsp27-1 & Hsp27-1 & AGGGGTGGGCATCCAGGCTAAGG & 64 & XM_055937 \\
\hline Hsp27-2 & Hsp27-2 & TCCTGACCCCCACACTCTACCA & 61 & NM_001541 \\
\hline Hsp27-2 & Hsp27-2 & GCTGCCTCСТCСТCTTCCTCTG & 61 & NM_001541 \\
\hline$\alpha \mathrm{A}-$ crystallin & $\alpha A$ & CCACCTCGGCTCCCTCGTCCTAAG & 64 & NM_000394 \\
\hline$\alpha A-$ crystallin & $\alpha \mathrm{A}$ & CCATGTCCCCAAGAGCGGCACTAC & 64 & NM_000394 \\
\hline RPL13a & RPL13a & GTATGCTGCCCCACAAAACCA & 58 & XM_027885 \\
\hline RPL13a & RPL13a & CAACGCATGAGGAATTAACAGTCTT & 58 & XM_027885 \\
\hline Metallothionein IF & MTIF & GCTTCTCTCTTGGAAAGTCC & 55 & M10943 \\
\hline Metallothionein IF & MTIF & GGCATCAGTCGCAGCAGCTG & 55 & M10943 \\
\hline Metallothionein IH & MTIH & GAACTCCAGTCTCACCTCGG & 55 & X64834 \\
\hline Metallothionein IH & MTIH & GACATCAGGCACAGCAGCTG & 55 & X64834 \\
\hline Metallothionein IG & MTIG & GCCTCTTCCCTTCTCGCTTG & 55 & XM_048213 \\
\hline Metallothionein IG & MTIG & GACATCAGGCGCAGCAGCTG & 55 & XM_048213 \\
\hline Glutathione Peroxidase 1 & GPX-1 & GACCGACCCCAAGCTCATCACC & 60 & M21304 \\
\hline Glutathione Peroxidase 1 & GPX-1 & ATCAACAGGACCAGCACCCATCTC & 60 & M21304 \\
\hline $\mathrm{Na}+/ \mathrm{H}+$ Exchanger II & $\mathrm{Na}+/ \mathrm{H}+\mathrm{Ex}$ & GCCATCTGTTTTGCGTTAGTGTTT & 56 & AF073299 \\
\hline $\mathrm{Na}+/ \mathrm{H}+$ Exchanger II & $\mathrm{Na}+/ \mathrm{H}+\mathrm{Ex}$ & GTTCGCTGACGGATTTGATAGAGA & 56 & AF073299 \\
\hline Serine/Threonine Protein Kinase & $\mathrm{S} / \mathrm{T} \mathrm{PK}$ & TGTTGGTGGGGATTTGCTTACTCT & 57 & NM_003607 \\
\hline Serine/Threonine Protein Kinase & $\mathrm{S} / \mathrm{T} \mathrm{PK}$ & CTTGGGCTGGAAACTGAAACCTCT & 57 & NM_003607 \\
\hline $\mathrm{Na}+/ \mathrm{K}+$ ATPase & $\mathrm{Na} / \mathrm{K}$ ATPase & AAAGTACAAAGATTCAGCCCAGAG & 52 & BC000006 \\
\hline $\mathrm{Na}+/ \mathrm{K}+$ ATPase & $\mathrm{Na} / \mathrm{K}$ ATPase & GGAGTTTGCCATAGTACGGATAAT & 52 & BC000006 \\
\hline Secreted Apoptosis Related Protein & SARP & TTGTAATCCAGTCGGCTTGTTCTT & 56 & AF017987 \\
\hline Secreted Apoptosis Related Protein & SARP & CTGGGCCTTTGCTGTCACTATTAC & 56 & AF017987 \\
\hline Pleiotrophin & Ple. & GTTCCCCGCCTTCCAGTCCA & 60 & M57399 \\
\hline Pleiotrophin & Ple. & TGCCCAGCCCACAGTCTCCA & 60 & M57399 \\
\hline E3-Ubiquitin Ligase & UBE3-Lig & CAGGGAATGGTTGTATCTCTTGTC & 53 & AY014180 \\
\hline E3-Ubiquitin Ligase & UBE3-Lig & AATGCCTCGTAAAAATCTCCAGTT & 53 & AY014180 \\
\hline$\alpha \mathrm{B}$-crystallin & $\alpha \mathrm{B}$ & AGCCGCCTCTTTGACCAGTTCTTC & 60 & NM_001885 \\
\hline$\alpha \mathrm{B}$-crystallin & $\alpha \mathrm{B}$ & GCGGTGACAGCAGGCTTCTCTTC & 60 & NM_001885 \\
\hline Catalase & Cat & TACCCCTCCTGGACTTTTTACATC & 52 & NM_001752 \\
\hline Catalase & Cat & CCTCATTCAGCACGTTCACATAGA & 52 & NM_001752 \\
\hline Metal-responsive Transcription Factor 1 & MTF-1 & GGGCCAGGACCTCAGCACAAT & 59 & XM_001412 \\
\hline Metal-responsive Transcription Factor 1 & MTF-1 & AGAAGCCCCAGCAACAACAGAAAG & 59 & XM_001412 \\
\hline
\end{tabular}


Table 2: Genes exhibiting increased expression in cataract relative to clear lenses.

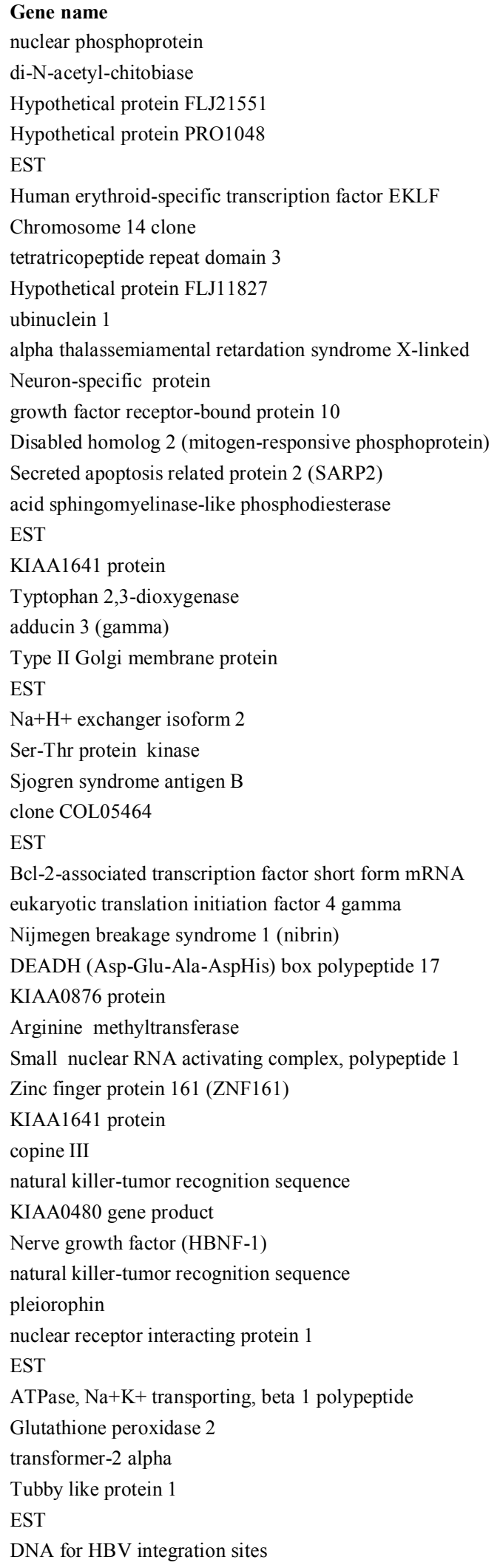

\begin{tabular}{|c|c|}
\hline Accession \# & Normal Intensity \\
\hline BE796924 & $348.8(P)$ \\
\hline NM_004388 & $117.2(\mathrm{~A})$ \\
\hline NM_024801 & $121(P)$ \\
\hline NM_018497 & $29.3(\mathrm{~A})$ \\
\hline AA972711 & $354.7(P)$ \\
\hline U65404 & $70.3(P)$ \\
\hline AC007956 & $154.4(\mathrm{P})$ \\
\hline AW510696 & $431.9(P)$ \\
\hline NM_025093 & $58.5(\mathrm{~A})$ \\
\hline T70262 & $397.9(\mathrm{P})$ \\
\hline AI650257 & $154.9(\mathrm{P})$ \\
\hline NM_014392 & $54.5(\mathrm{~A})$ \\
\hline D86962 & $126.6(\mathrm{P})$ \\
\hline NM_001343 & $237(P)$ \\
\hline AF017987 & $473.2(P)$ \\
\hline AA 873600 & $48.7(\mathrm{~A})$ \\
\hline AI694562 & $2039.8(P)$ \\
\hline NM_025190 & $178.7(\mathrm{P})$ \\
\hline NM_005651 & $37.4(\mathrm{~A})$ \\
\hline AI763123 & $100.8(\mathrm{~A})$ \\
\hline NM_014498 & $100(\mathrm{~A})$ \\
\hline AA634446 & $13.3(\mathrm{~A})$ \\
\hline AF073299 & $133.9(\mathrm{~A})$ \\
\hline NM_003607 & $1015.2(P)$ \\
\hline BG532929 & $47.8(\mathrm{~A})$ \\
\hline AK025143 & $68.1(\mathrm{~A})$ \\
\hline BF592782 & $479.5(\mathrm{P})$ \\
\hline AF249273 & $94.5(\mathrm{P})$ \\
\hline BE966878 & $112.4(\mathrm{P})$ \\
\hline AI796269 & $83.6(\mathrm{~A})$ \\
\hline AW188131 & $153.2(\mathrm{~A})$ \\
\hline AW237172 & $128.9(\mathrm{~A})$ \\
\hline U79286 & $62.8(\mathrm{~A})$ \\
\hline NM_003082 & $145.6(P)$ \\
\hline NM_007146 & $81.9(\mathrm{~A})$ \\
\hline AB046861 & $32(\mathrm{~A})$ \\
\hline AA541758 & $96.6(\mathrm{~A})$ \\
\hline AI361805 & $398.2(\mathrm{P})$ \\
\hline AW299294 & $154(\mathrm{P})$ \\
\hline M57399 & $1448.1(\mathrm{P})$ \\
\hline AI688640 & $95.4(\mathrm{P})$ \\
\hline ВC005916 & $1187.8(\mathrm{P})$ \\
\hline AI824012 & $58.3(\mathrm{~A})$ \\
\hline AW293343 & $84.3(\mathrm{P})$ \\
\hline ВC000006 & $1233.8(\mathrm{P})$ \\
\hline NM_002083 & $31.7(\mathrm{~A})$ \\
\hline AW978896 & $97(\mathrm{~A})$ \\
\hline NM_003322 & $27.3(\mathrm{~A})$ \\
\hline BF448315 & $197.7(P)$ \\
\hline X04014 & $80.7(\mathrm{~A})$ \\
\hline
\end{tabular}

\begin{tabular}{|c|c|}
\hline Cataract Intensity & Fold \\
\hline $1730.7(\mathrm{P})$ & 5.28 \\
\hline $322.9(P)$ & 5.28 \\
\hline $524.5(P)$ & 5.28 \\
\hline $261.1(P)$ & 5.28 \\
\hline $1919.5(\mathrm{P})$ & 5.28 \\
\hline $408.9(P)$ & 5.28 \\
\hline $649.3(P)$ & 5.66 \\
\hline $1752.4(\mathrm{P})$ & 5.66 \\
\hline $338.9(P)$ & 5.66 \\
\hline $1981.9(\mathrm{P})$ & 5.66 \\
\hline $852.1(P)$ & 5.66 \\
\hline $338.2(P)$ & 5.66 \\
\hline $544.2(\mathrm{P})$ & 5.66 \\
\hline $1096.6(\mathrm{P})$ & 6.06 \\
\hline $3068.6(P)$ & 6.06 \\
\hline $264.1(P)$ & 6.06 \\
\hline $14553.9(P)$ & 6.06 \\
\hline $878.1(P)$ & 6.06 \\
\hline $324.8(\mathrm{P})$ & 6.06 \\
\hline $379.3(P)$ & 6.06 \\
\hline $618.9(P)$ & 6.06 \\
\hline $137.2(\mathrm{P})$ & 6.5 \\
\hline $1443.4(P)$ & 6.5 \\
\hline $3771(P)$ & 6.5 \\
\hline $374.3(P)$ & 6.5 \\
\hline $571.6(P)$ & 6.5 \\
\hline $3072.6(P)$ & 6.5 \\
\hline $518.1(P)$ & 6.5 \\
\hline $612.6(P)$ & 6.5 \\
\hline $1188(P)$ & 6.96 \\
\hline $1396(P)$ & 6.96 \\
\hline $1181.2(\mathrm{P})$ & 6.96 \\
\hline $366.1(P)$ & 6.96 \\
\hline $643.5(\mathrm{P})$ & 6.96 \\
\hline $446.7(\mathrm{P})$ & 6.96 \\
\hline $201.3(P)$ & 6.96 \\
\hline $775.4(\mathrm{P})$ & 6.96 \\
\hline $2412.8(\mathrm{P})$ & 6.96 \\
\hline $997.5(\mathrm{P})$ & 7.46 \\
\hline $7425.6(\mathrm{P})$ & 7.46 \\
\hline $829(P)$ & 7.46 \\
\hline $10502.3(P)$ & 7.46 \\
\hline $383.9(P)$ & 7.46 \\
\hline $630.2(P)$ & 7.46 \\
\hline $14152(P)$ & 8 \\
\hline $257.1(P)$ & 8 \\
\hline $618.3(P)$ & 8 \\
\hline $211.3(P)$ & 8 \\
\hline $1500.5(\mathrm{P})$ & 8 \\
\hline $607.8(\mathrm{P})$ & 8 \\
\hline
\end{tabular}


similar to widely-interspaced zinc finger motifs

cDNA DKFZp566M043

secretory carrier membrane protein 1

chondroitin sulfate proteoglycan 6 (bamacan)

KIAA0594 protein

Claudin 1 (CLDN1)

KIAA0256 gene product

HRIHFB2017

KIAA0888 protein

Osteomodulin

Bicaudal-D (BICD)

EST

cDNA: FLJ21198

KIAA0447 gene product

chloride channel 3

Wiskott-Aldrich syndrome-like

Cofactor required for Sp1 transcriptional activation, subunit 2

KIAA0494 gene product

ring finger protein 15

myeloidlymphoid or mixed-lineage leukemia

PRO2667

cDNA DKFZp564M2422

Similar to histamine N-methyltransferase

Testis-specific XK-related protein on $\mathrm{Y}$

Genes exhibiting decreased expression in cataract relative to clear lenses.

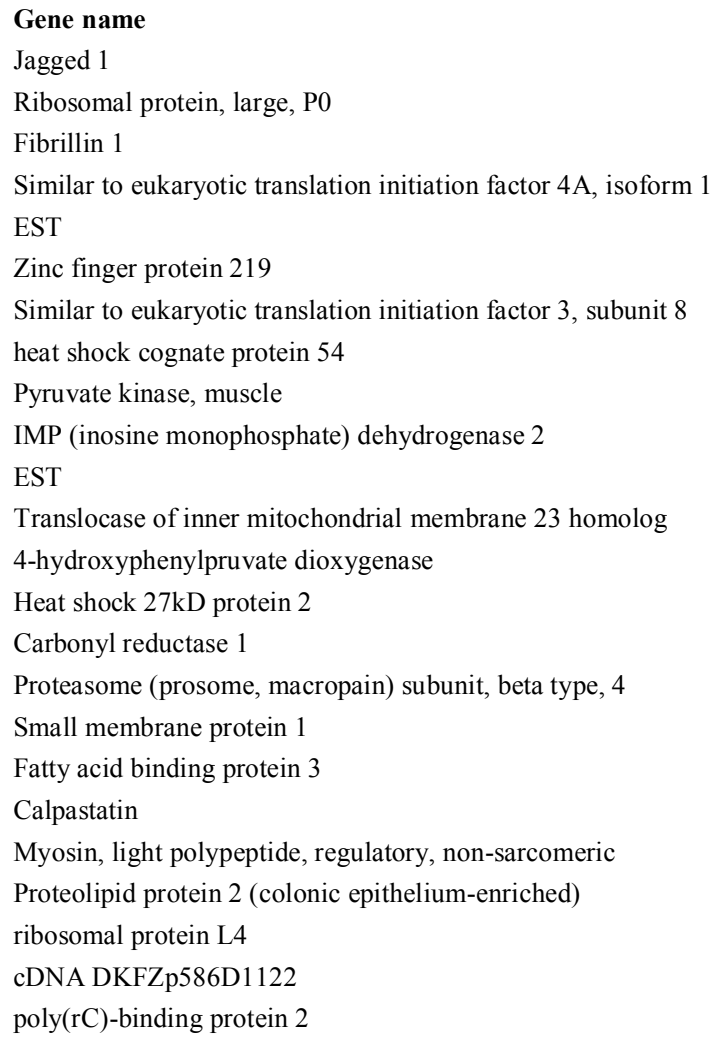

$\begin{array}{lc}\text { AI828531 } & 34.6(\mathrm{~A}) \\ \text { AL050065 } & 36.2(\mathrm{~A}) \\ \text { BF058944 } & 177.3(\mathrm{P}) \\ \text { AI373676 } & 71.3(\mathrm{P}) \\ \text { AW183677 } & 39.1(\mathrm{~A}) \\ \text { NM_021101 } & 41 \text { (A) } \\ \text { N52532 } & 71.7(\mathrm{~A}) \\ \text { AB015331 } & 64.1(\mathrm{~A}) \\ \text { AB020695 } & 173.8(\mathrm{~A}) \\ \text { AI765819 } & 26.4(\mathrm{~A}) \\ \text { U90030 } & 40.8(\mathrm{~A}) \\ \text { AI278204 } & 46.2(\mathrm{~A}) \\ \text { AK024851 } & 13.5(\mathrm{~A}) \\ \text { BE885244 } & 45.2(\mathrm{~A}) \\ \text { AA902971 } & 25.7(\mathrm{~A}) \\ \text { BE504979 } & 51.4(\mathrm{~A}) \\ \text { NM_004229 } & 9.2(\mathrm{~A}) \\ \text { BC002525 } & 15.5(\mathrm{~A}) \\ \text { AU157590 } & 62.5(\mathrm{~A}) \\ \text { AA715041 } & 39.2(\mathrm{~A}) \\ \text { AF119889 } & 31.3(\mathrm{~A}) \\ \text { AL050388 } & 4.2(\mathrm{~A}) \\ \text { BC005907 } & 10.4(\mathrm{~A}) \\ \text { NM_004677 } & 4.3(\mathrm{~A})\end{array}$

Accesion \#

U73936

NM_001002

NM 000138

BC006210

AI799802

NM 016423

BC000533

AB034951

NM_002654

NM_000884

AI816291

NM_006327

NM_002150

NM_001541

BC002511

NM_002796

NM_014313

NM_004102

AF327443

NM_006471

NM_002668

AI953886

AL050166

NM_005016

Normal Intensity
$916.3(\mathrm{P})$
$14191.2(\mathrm{P})$
$404.2(\mathrm{P})$
$2672.3(\mathrm{P})$
$228.4(\mathrm{P})$
$300.2(\mathrm{P})$
$2697.1(\mathrm{P})$
$1342.6(\mathrm{P})$
$1098.2(\mathrm{P})$
$1011.6(\mathrm{P})$
$458.9(\mathrm{P})$
$435.6(\mathrm{P})$
$206.7(\mathrm{P})$
$1056.5(\mathrm{P})$
$589.2(\mathrm{P})$
$875.3(\mathrm{P})$
$502(\mathrm{P})$
$244(\mathrm{P})$
$300.3(\mathrm{P})$
$3899.8(\mathrm{P})$
$437.4(\mathrm{P})$
$6333.2(\mathrm{P})$
$199.2(\mathrm{P})$
$1855.1(\mathrm{P})$

$\begin{array}{cc}\text { Cataract Intensity } & \text { Fold } \\ 69.9(\mathrm{~A}) & 5.28 \\ 3138.4(\mathrm{P}) & 5.28 \\ 55.2(\mathrm{~A}) & 5.28 \\ 494.9(\mathrm{~A}) & 5.28 \\ 23.1(\mathrm{~A}) & 5.28 \\ 53.3(\mathrm{~A}) & 5.28 \\ 471.5(\mathrm{P}) & 5.28 \\ 152(\mathrm{~A}) & 5.28 \\ 221.9(\mathrm{~A}) & 5.28 \\ 124.8(\mathrm{~A}) & 5.28 \\ 66.1(\mathrm{~A}) & 5.28 \\ 86.5(\mathrm{~A}) & 5.28 \\ 36.9(\mathrm{~A}) & 5.28 \\ 172.3(\mathrm{~A}) & 5.28 \\ 27.6(\mathrm{~A}) & 5.28 \\ 143(\mathrm{~A}) & 5.28 \\ 78.7(\mathrm{~A}) & 5.28 \\ 48.2(\mathrm{~A}) & 5.28 \\ 81.1(\mathrm{~A}) & 5.28 \\ 876.3(\mathrm{P}) & 5.28 \\ 50.8(\mathrm{~A}) & 5.28 \\ 716.8(\mathrm{P}) & 5.28 \\ 29.6(\mathrm{~A}) & 5.28 \\ 204.4(\mathrm{~A}) & 5.28\end{array}$

$\begin{array}{cc}273.6(\mathrm{P}) & 8 \\ 322.8(\mathrm{P}) & 8.57 \\ 928.9 \mathrm{P}) & 8.57 \\ 1010.3(\mathrm{P}) & 8.57 \\ 404.7(\mathrm{P}) & 9.19 \\ 268.1(\mathrm{P}) & 9.85 \\ 1709.6(\mathrm{P}) & 9.85 \\ 368.4(\mathrm{P}) & 9.85 \\ 2224.6(\mathrm{P}) & 10.56 \\ 351.8(\mathrm{P}) & 11.31 \\ 888.1(\mathrm{P}) & 12.13 \\ 331.8(\mathrm{P}) & 12.13 \\ 217.6(\mathrm{P}) & 12.13 \\ 664(\mathrm{P}) & 13 \\ 221.7(\mathrm{P}) & 14.93 \\ 686(\mathrm{P}) & 14.93 \\ 196.8(\mathrm{P}) & 16 \\ 419.6(\mathrm{P}) & 17.15 \\ 719.2(\mathrm{P}) & 19.7 \\ 518.1(\mathrm{P}) & 19.7 \\ 717.7(\mathrm{P}) & 19.7 \\ 185.4(\mathrm{P}) & 19.7 \\ 308(\mathrm{P}) & 27.86 \\ 124.2(\mathrm{P}) & 32\end{array}$


Metallothionein If gene

3-hydroxy-3-methylglutaryl-Coenzyme A reductase

G8 protein

SMX5-like protein

Microtubule-associated proteins 1A1B light chain 3

PRO2640

MYLE protein

Cold shock domain protein A

kinesin 2

Cell membrane glycoproein

Biliverdin reductase

Nuclear localization signal deleted in velocardiofacial syndrome

clone RP11-486O2

proteasome (prosome, macropain) subunit, alpha type, 3

Cyclin D1

Heat shock $70 \mathrm{kD}$ protein $1 \mathrm{~B}$

CD24 signal transducer

Zyxin related protein ZRP-1

solute carrier family 2 (facilitated glucose transporter), member 3

Tubulin, beta 5

weakly similar to LONGEVIY-ASSURANCE PROTEIN 1

clone 1033B10

S-adenosylhomocysteine hydrolase (AHCY)

ribosomal protein, large, $\mathrm{P} 0$

Ovarian beta-A inhibin

MYG1 protein

ribosomal protein L13

Splicing factor arginineserine-rich 9

HDCMB21P gene

Goliath protein

Eukaryotic translation initiation factor $2 \mathrm{~B}$, subunit 1

ribosomal protein L13

Proteasome (prosome, macropain) subunit, beta type, 7

Tubulin, beta, 2

Phosphatidylethanolamine N-methyltransferase

Adaptor-related protein complex 2, mu 1 subunit

cDNA DKFZp564B076

clone RP4-781L3

Alpha-actinin-2 associated LIM protein mRNA

Threonyl-tRNA synthetase

MCP-1=monocyte chemotactic protein

eukaryotic translation elongation factor 1 gamma

Lectin, galactoside-binding, soluble, 1 (galectin 1)

CGI-44 protein; sulfide dehydrogenase like

DnaJ (Hsp40) homolog, subfamily B, member 1

Fragile histidine triad gene

Carboxypeptidase B1

Crystallin, beta B2

Meiotic recombination protein REC14

Selenoprotein W, 1

mRNA for hMBF1alpha

tudor repeat associator with PCT AIRE 2

EST

Clone: SMAP31-12
M10943

AL518627

NM_016947

AF196468

AF183417

AF116710

NM_014015

NM_003651

AA284075

NM_007002

NM_000713

NM_003776

AL356115

NM_002788

BC000076

NM_005346

L33930

AF000974

BE550486

BC005838

AK001105

AL031228

NM_000687

AI953822

M13436

NM_021640

AI1 86735

NM_003769

AF072098

NM_018434

NM_001414

AW574664

NM_002799

BC004188

NM_007169

NM_004068

AL049313

AL121994

AF002280

NM_003191

S69738

BE963164

NM_002305

NM_021199

BG537255

HN_002012

NM_001871

NM_000496

AF309553

NM_003009

AB002282

AW129593

AV705559

AB059408

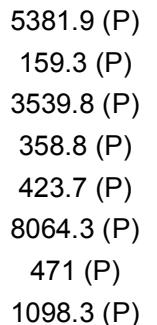

$236.3(\mathrm{P})$

$368.8(\mathrm{P})$

$1583.4(P)$

$970.5(\mathrm{P})$

$10470(P)$

$452(\mathrm{P})$

$182.7(P)$

$1660.9(\mathrm{P})$

$736.9(\mathrm{P})$

$792.4(\mathrm{P})$

$210.6(\mathrm{P})$

$3024.6(P)$

$1037.6(P)$

$565(\mathrm{P})$

$365.9(\mathrm{P})$

$8792.1(\mathrm{P})$

$6485.9(\mathrm{P})$

$583.2(\mathrm{P})$

$7108.6(\mathrm{P})$

$1438.8(\mathrm{P})$

$10344.7(P)$

$340.6(\mathrm{P})$

$281.1(\mathrm{P})$

$3994.8(\mathrm{P})$

2050 (P)

$1084.5(P)$

$670.3(\mathrm{P})$

$863.9(P)$

$470.2(\mathrm{P})$

$897.8(\mathrm{P})$

$189.4(\mathrm{P})$

$958(\mathrm{P})$

$771(\mathrm{P})$

$13185.4(\mathrm{P})$

$2609.9(P)$

$1703.9(\mathrm{P})$

$532.8(\mathrm{P})$

$341.8(\mathrm{P})$

$337.8(\mathrm{P})$

$20885.8(P)$

$134.4(P)$

$707.1(P)$

$2012.1(P)$

$2669.4(\mathrm{P})$

$593.1(P)$

$483.7(P)$
$776.9(\mathrm{~A}) \quad 5.66$

$30.3(\mathrm{~A}) \quad 5.66$

$558.7(P) \quad 5.66$

$39.1(\mathrm{~A}) \quad 5.66$

$79.3(\mathrm{~A}) \quad 5.66$

$991.9(\mathrm{P}) \quad 5.66$

$52.6(\mathrm{~A}) \quad 5.66$

$144.3(\mathrm{~A}) \quad 5.66$

$40.9(\mathrm{~A}) \quad 5.66$

$75.1(\mathrm{~A}) \quad 5.66$

$498.1(P) \quad 5.66$

$125.9(\mathrm{~A}) \quad 5.66$

$1310.9(P) \quad 5.66$

$46(\mathrm{~A}) \quad 5.66$

$21.7(\mathrm{~A}) \quad 5.66$

$397.7(P) \quad 5.66$

$187.1(\mathrm{~A}) \quad 5.66$

$113.6(\mathrm{~A}) \quad 5.66$

$76.2(\mathrm{~A}) \quad 5.66$

$533.4(M) \quad 5.66$

$178.7(\mathrm{~A}) \quad 5.66$

$92(\mathrm{~A}) \quad 6.06$

$59.1(\mathrm{~A}) \quad 6.06$

$1133.5(P) \quad 6.06$

$898.3(P) \quad 6.06$

$103.9(\mathrm{~A}) \quad 6.06$

$1468.8(P) \quad 6.06$

$422.6(\mathrm{~A}) \quad 6.06$

$699.8(\mathrm{P}) \quad 6.06$

$28.8(\mathrm{~A}) \quad 6.06$

$54.1(\mathrm{~A}) \quad 6.06$

$371.4(\mathrm{~A}) \quad 6.06$

$332.4(\mathrm{M}) \quad 6.06$

$202.4(\mathrm{~A}) \quad 6.06$

$47.1(\mathrm{~A}) \quad 6.06$

$165.4(\mathrm{~A}) \quad 6.06$

$52.3(\mathrm{~A}) \quad 6.06$

$150.3(\mathrm{~A}) \quad 6.06$

$28.7(\mathrm{~A}) \quad 6.06$

$97.8(\mathrm{~A}) \quad 6.06$

$73(\mathrm{~A}) \quad 6.5$

$1579.7(A) \quad 6.5$

$94.5(\mathrm{~A}) \quad 6.5$

$151.3(\mathrm{~A}) \quad 6.5$

$77.4(\mathrm{~A}) \quad 6.5$

$59.8(\mathrm{~A}) \quad 6.5$

$35.4(\mathrm{~A}) \quad 6.5$

$3332.7(P) \quad 6.5$

$34.9(\mathrm{~A}) \quad 6.5$

$39.3(\mathrm{~A}) \quad 6.5$

$211.9(\mathrm{~A}) \quad 6.5$

$387.8(\mathrm{M}) \quad 6.5$

$107.4(\mathrm{~A}) \quad 6.5$

$68.1(\mathrm{~A}) \quad 6.5$ 
Growth arrest and DNA damage inducible protein beta

Crystallin, gamma B

Eukaryotic translation elongation factor 1 delta

FK506-binding protein 2

HLA class II region expressed gene KE2

Neuronal cell adhesion molecule

polymerase (RNA) II (DNA directed) polypeptide J

Ribosomal protein L27a

EST

Tetraspan 3

phosphoserine aminotransferase

Nuclear prelamin A recognition factor

Zinc finger protein homologous to Zfp-36 in mouse

cDNA DKFZp564J1516

Antizyme inhibitor

G protein-coupled receptor 39

prostatic binding protein

Tetratricopeptide repeat domain 2

Ribosomal protein S15

Hypothetical protein FLJ11730

kinesin 2

Prefoldin 5

Poly(A)-binding protein, cytoplasmic 4 (inducible form)

Ribosomal protein $\mathrm{L} 35$

Catenin (cadherin-associated protein), alpha 2

Hypothetical protein FLJ10493

Lysosomal-associated membrane protein 1

Human growth hormone-dependent insulin

glutathione peroxidase 3

Prostatic binding protein

GMPR2 for guanosine monophosphate reductase isolog

hemoglobin, alpha 1

Ribosomal protein L8

F-box protein FLR1

Homo sapiens, Similar to tubulin, beta, 4

Ribosomal protein L29

KIAA0874 protein

CGI-91 protein

Pre-mRNA splicing factor 2 p32 subunit

Phosphoglycerate kinase 1

Human 28S rRNA sequence

Similar to granulin

hypothetical protein FLJ10698

solute carrier family 25 member 6

SKIP for skeletal muscle and kidney enriched inositol phosphatase

Protein kinase

Extracellular matrix protein 1

Alpha II spectrin

nucleophosminB23.2

Ribosomal protein L4

Phosphatidylcholine transfer protein

SEC13 (S. cerevisiae)-like 1

Homo sapiens mRNA for puromycin sensitive aminopeptidase

Eukaryotic translation initiation factor 3, subunit 4

\begin{tabular}{|c|c|}
\hline AF087853 & $1895.6(P)$ \\
\hline NM_005210 & $721(P)$ \\
\hline NM_001960 & $3814.7(\mathrm{P})$ \\
\hline NM_004470 & $503.6(P)$ \\
\hline NM_014260 & $382.3(\mathrm{P})$ \\
\hline NM_005010 & $613.1(P)$ \\
\hline BG335629 & $552.8(\mathrm{P})$ \\
\hline NM_000990 & $12053.7(P)$ \\
\hline L43577 & $354.2(P)$ \\
\hline NM_005724 & $183(\mathrm{P})$ \\
\hline AI889380 & $4608.5(\mathrm{P})$ \\
\hline NM_012336 & $482(\mathrm{P})$ \\
\hline NM_003407 & $651.1(P)$ \\
\hline AL136601 & $192.2(\mathrm{P})$ \\
\hline NM_015878 & $232.8(P)$ \\
\hline AL567376 & $257(P)$ \\
\hline BE969671 & $3392.7(P)$ \\
\hline NM_003315 & $397.2(P)$ \\
\hline NM_001018 & $15776.8(\mathrm{P})$ \\
\hline NM_022756 & $639.3(P)$ \\
\hline AA284075 & $199.9(\mathrm{P})$ \\
\hline NM_002624 & $2490.6(P)$ \\
\hline NM_003819 & $437.9(P)$ \\
\hline NM_007209 & $6130.5(P)$ \\
\hline NM_004389 & $350.7(P)$ \\
\hline NM_018112 & $107.9(\mathrm{P})$ \\
\hline NM_005561 & $888.3(P)$ \\
\hline M31159 & $2003.6(P)$ \\
\hline AW149846 & $5548.5(\mathrm{P})$ \\
\hline NM_002567 & $4056.2(\mathrm{P})$ \\
\hline NM_016576 & $584.3(\mathrm{P})$ \\
\hline T50399 & $427.5(P)$ \\
\hline NM_000973 & $5766.6(P)$ \\
\hline AF142481 & $771.2(\mathrm{P})$ \\
\hline ВC002654 & $1096.5(P)$ \\
\hline NM_000992 & $1889.9(P)$ \\
\hline $\mathrm{AB} 020681$ & $249.4(P)$ \\
\hline NM_016034 & $327.1(P)$ \\
\hline L04636 & $518.2(\mathrm{P})$ \\
\hline NM_000291 & $2262.5(\mathrm{P})$ \\
\hline M11167 & $3708.3(P)$ \\
\hline BC000324 & $480(\mathrm{P})$ \\
\hline AI951798 & $422.6(P)$ \\
\hline AI961224 & $6069.8(\mathrm{P})$ \\
\hline AI806031 & $249.4(P)$ \\
\hline AF133207 & $2162.2(P)$ \\
\hline U65932 & $1252.6(\mathrm{P})$ \\
\hline U83867 & $843.9(P)$ \\
\hline AB042278 & $655(P)$ \\
\hline NM_000968 & $7153.3(\mathrm{P})$ \\
\hline NM_021213 & $205(P)$ \\
\hline NM_030673 & $420.4(P)$ \\
\hline AJ132583 & $303.3(P)$ \\
\hline ВC000733 & $1480(P)$ \\
\hline
\end{tabular}

\begin{tabular}{|c|c|}
\hline $39.3(\mathrm{~A})$ & 6.5 \\
\hline $104.8(\mathrm{~A})$ & 6.5 \\
\hline $480.1(\mathrm{~A})$ & 6.5 \\
\hline $17.5(\mathrm{~A})$ & 6.5 \\
\hline $30.3(\mathrm{~A})$ & 6.5 \\
\hline $94.8(\mathrm{~A})$ & 6.5 \\
\hline $31.8(\mathrm{~A})$ & 6.5 \\
\hline $1609.9(\mathrm{P})$ & 6.5 \\
\hline $43(\mathrm{~A})$ & 6.96 \\
\hline $21.3(\mathrm{~A})$ & 6.96 \\
\hline $970.4(P)$ & 6.96 \\
\hline $58.2(\mathrm{~A})$ & 6.96 \\
\hline $63.6(\mathrm{~A})$ & 6.96 \\
\hline $30.5(\mathrm{~A})$ & 6.96 \\
\hline $25.5(\mathrm{~A})$ & 6.96 \\
\hline $63.1(\mathrm{~A})$ & 6.96 \\
\hline $310.4(P)$ & 6.96 \\
\hline $43.4(\mathrm{~A})$ & 6.96 \\
\hline $2287.8(\mathrm{P})$ & 6.96 \\
\hline $105.1(\mathrm{~A})$ & 6.96 \\
\hline $21.7(\mathrm{~A})$ & 6.96 \\
\hline $261.6(\mathrm{~A})$ & 6.96 \\
\hline $32.9(\mathrm{~A})$ & 6.96 \\
\hline $732.7(\mathrm{P})$ & 6.96 \\
\hline $28.5(\mathrm{~A})$ & 6.96 \\
\hline $17.8(\mathrm{~A})$ & 6.96 \\
\hline $54.1(\mathrm{~A})$ & 6.96 \\
\hline $285.9(P)$ & 6.96 \\
\hline $521(P)$ & 6.96 \\
\hline $356.9(\mathrm{~A})$ & 7.46 \\
\hline $38.3(\mathrm{~A})$ & 7.46 \\
\hline 75.7 (A) & 7.46 \\
\hline $462.4(\mathrm{~A})$ & 7.46 \\
\hline $114.6(\mathrm{~A})$ & 7.46 \\
\hline $127.3(\mathrm{~A})$ & 7.46 \\
\hline $228.7(\mathrm{~A})$ & 7.46 \\
\hline $45.6(\mathrm{~A})$ & 7.46 \\
\hline $49.7(\mathrm{~A})$ & 7.46 \\
\hline $46.5(\mathrm{~A})$ & 7.46 \\
\hline $332.5(P)$ & 7.46 \\
\hline $648.4(P)$ & 7.46 \\
\hline $65.7(\mathrm{~A})$ & 8 \\
\hline $49(\mathrm{~A})$ & 8 \\
\hline $397.1(\mathrm{~A})$ & 8 \\
\hline $30.6(\mathrm{~A})$ & 8 \\
\hline $316(A)$ & 8 \\
\hline $150.3(\mathrm{~A})$ & 8 \\
\hline $96.5(\mathrm{~A})$ & 8 \\
\hline $70.7(\mathrm{~A})$ & 8 \\
\hline $854.4(P)$ & 8 \\
\hline $23.8(\mathrm{~A})$ & 8 \\
\hline $37.6(\mathrm{~A})$ & 8 \\
\hline $39.2(\mathrm{~A})$ & 8 \\
\hline $131.3(\mathrm{~A})$ & 8 \\
\hline
\end{tabular}


SET translocation (myeloid leukemia-associated)

PRO1608

Human bcl-1 mRNA

ECSIT

MCT-1 protein

Human soluble protein Jagged mRNA

nidogen (enactin)

Mitochondrial robosomal protein S15

Proteasome (prosome, macropain) subunit, beta type, 1

Translocase of inner mitochondrial membrane 17

Microfibrillar-associated protein 2 , transcript variant 1

Ribosomal protein L4

Zinc finger protein 162

Tyrosine 3-monoxygenasetryptophan

Spinde pole body protein

Glycogenin

6-pyruvoyl-tetrahydropterin synthasedimerization cofactor

\section{Moesin}

Nuclear autoantigenic sperm protein (histone-binding)

Metalloprotease

KIAA0116 protein

GAPDH

Brain acid-soluble protein 1

HSPC177

glyceraldehyde-3-phosphate dehydrogenase

Latent transforming growh factor beta binding protein 3

U6 snRNA-associated Sm-like protein LSm7

GANP protein

McKusick-Kaufman syndrome protein

Clone image:3611719

Cyclin G1

Microtubule associated protein

MM-1 beta

transketolase

$78 \mathrm{kDa}$ gastrin-binding protein

SH3 domain binding glutamic acid-rich protein

EEF1 gamma

phospholipase $\mathrm{C}$, beta 3

Glutathione peroxidase 3

RD protein

Adaptor-related protein complex 2

Phosphomannomutase 1

Quinone oxidoreductase homolog

HSPCO34 protein

Ornithin decarboxylase antizyme 1

JM5 protein

Retinitis pigmentosa 2

Guanine nucleotide binding protein beta polypeptide 2-like 1

Cytidine deaminase

alpha-2-HS-glycoprotein

Ribosomal protein L11

L-iditol-2 dehydrogenase

v-fos FBJ murine osteosarcoma viral oncogene homolog

Crystallin beta B2

\begin{tabular}{|c|c|}
\hline AI278616 & $459(\mathrm{P})$ \\
\hline AF119850 & $10333.9(\mathrm{P})$ \\
\hline M73554 & $780.7(\mathrm{P})$ \\
\hline NM_016581 & $238.5(P)$ \\
\hline NM_014060 & $328.5(P)$ \\
\hline U77914 & $1063.3(P)$ \\
\hline BF940043 & $608.8(P)$ \\
\hline NM_031280 & $132.4(\mathrm{P})$ \\
\hline NM_002793 & $1915.3(P)$ \\
\hline ВC004439 & $128.3(P)$ \\
\hline NM_017459 & $233.4(P)$ \\
\hline $\mathrm{BC} 005817$ & $7644.3(\mathrm{P})$ \\
\hline NM_004630 & $734.7(P)$ \\
\hline $\mathrm{BC} 003623$ & $373.6(P)$ \\
\hline NM_006322 & $215.4(P)$ \\
\hline NM_004130 & $407(\mathrm{P})$ \\
\hline NM_000281 & $217.7(P)$ \\
\hline NM_002444 & $974.5(\mathrm{P})$ \\
\hline NM_002482 & $155.1(P)$ \\
\hline NM_007038 & $220.2(P)$ \\
\hline AL581473 & $822.7(P)$ \\
\hline M33197 & $5091.6(P)$ \\
\hline NM_006317 & $7329.2(P)$ \\
\hline NM_016410 & $310.9(P)$ \\
\hline BF689355 & $9541.6(\mathrm{P})$ \\
\hline NM_021070 & $377.9(P)$ \\
\hline NM_016199 & $395.4(P)$ \\
\hline AJ010089 & $462.1(P)$ \\
\hline NM_018848 & $533.2(P)$ \\
\hline ВC003542 & $167(P)$ \\
\hline ВC000196 & $4919.8(P)$ \\
\hline AI633566 & $402.3(\mathrm{P})$ \\
\hline $\mathrm{AB} 055804$ & $1917.7(\mathrm{P})$ \\
\hline L12711 & $5334(P)$ \\
\hline U04627 & $370.5(P)$ \\
\hline NM_007341 & $682.4(P)$ \\
\hline NM_001404 & $9570.8(\mathrm{P})$ \\
\hline BE305165 & $419.7(P)$ \\
\hline NM_002084 & $9749.5(\mathrm{P})$ \\
\hline L03411 & $506.3(P)$ \\
\hline NM_021575 & $225(P)$ \\
\hline NM_002676 & $238.4(P)$ \\
\hline $\mathrm{BC} 000474$ & $934(P)$ \\
\hline NM_016126 & $217.9(P)$ \\
\hline AF090094 & $1153.7(P)$ \\
\hline ВС000464 & $327.3(P)$ \\
\hline NM_006915 & $33.1(P)$ \\
\hline NM_006098 & $3013.5(P)$ \\
\hline NM_001785 & $324.7(P)$ \\
\hline BG538564 & $3032.1(P)$ \\
\hline NM_000975 & $4539.6(\mathrm{P})$ \\
\hline L29008 & $1540.6(\mathrm{P})$ \\
\hline ВC004490 & $508.5(P)$ \\
\hline NM 000496 & $18394.2(\mathrm{P})$ \\
\hline
\end{tabular}

\begin{tabular}{|c|c|}
\hline 35.1 (A) & 8 \\
\hline $1251.4(\mathrm{P})$ & 8 \\
\hline $139.7(\mathrm{~A})$ & 8.57 \\
\hline $27.4(\mathrm{~A})$ & 8.57 \\
\hline $20.5(\mathrm{~A})$ & 8.57 \\
\hline $109.4(\mathrm{~A})$ & 8.57 \\
\hline $93.6(\mathrm{~A})$ & 8.57 \\
\hline $11.3(\mathrm{~A})$ & 8.57 \\
\hline $357.2(\mathrm{~A})$ & 8.57 \\
\hline $7.6(\mathrm{~A})$ & 9.19 \\
\hline $23.6(\mathrm{~A})$ & 9.19 \\
\hline $816.1(P)$ & 9.19 \\
\hline $25.1(\mathrm{~A})$ & 9.19 \\
\hline $32.5(\mathrm{~A})$ & 9.19 \\
\hline $12.6(\mathrm{~A})$ & 9.19 \\
\hline $30.8(\mathrm{~A})$ & 9.85 \\
\hline $13.4(\mathrm{~A})$ & 9.85 \\
\hline $38.7(\mathrm{~A})$ & 9.85 \\
\hline $16.4(\mathrm{~A})$ & 9.85 \\
\hline $9.9(\mathrm{~A})$ & 9.85 \\
\hline $45.9(\mathrm{~A})$ & 9.85 \\
\hline $530.9(\mathrm{~A})$ & 9.85 \\
\hline $674(\mathrm{P})$ & 9.85 \\
\hline $30.8(A)$ & 9.85 \\
\hline $1048.9(P)$ & 9.85 \\
\hline $39(A)$ & 9.85 \\
\hline $37(A)$ & 10.56 \\
\hline $29.2(A)$ & 10.56 \\
\hline $20.9(\mathrm{~A})$ & 10.56 \\
\hline $22.2(\mathrm{~A})$ & 10.56 \\
\hline $480.8(\mathrm{~A})$ & 10.56 \\
\hline $44.9(\mathrm{~A})$ & 10.56 \\
\hline $106.5(\mathrm{~A})$ & 10.56 \\
\hline $535.8(P)$ & 10.56 \\
\hline $24.3(\mathrm{~A})$ & 10.56 \\
\hline $38.7(\mathrm{~A})$ & 10.56 \\
\hline $935.6(\mathrm{~A})$ & 10.56 \\
\hline $42.3(\mathrm{~A})$ & 10.56 \\
\hline $594.4(\mathrm{P})$ & 11.31 \\
\hline $40.5(\mathrm{~A})$ & 11.31 \\
\hline $19.3(\mathrm{~A})$ & 11.31 \\
\hline $40.7(\mathrm{~A})$ & 11.31 \\
\hline $50.2(\mathrm{~A})$ & 11.31 \\
\hline $12.8(\mathrm{~A})$ & 11.31 \\
\hline $36.4(\mathrm{~A})$ & 11.31 \\
\hline $30.5(\mathrm{~A})$ & 12.13 \\
\hline $1.3(\mathrm{~A})$ & 12.13 \\
\hline $315.4(\mathrm{~A})$ & 12.13 \\
\hline $23.4(\mathrm{~A})$ & 12.13 \\
\hline $152.1(\mathrm{~A})$ & 12.13 \\
\hline $162.2(\mathrm{~A})$ & 12.13 \\
\hline $93.4(\mathrm{~A})$ & 12.13 \\
\hline $17.2(\mathrm{~A})$ & 12.13 \\
\hline $1113.3(P)$ & 12.13 \\
\hline
\end{tabular}




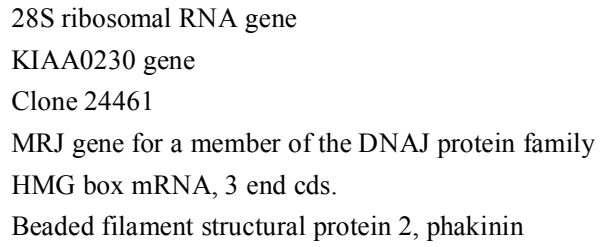

\begin{tabular}{|c|}
\hline $3810.6(P)$ \\
\hline $300.7(P)$ \\
\hline $517.8(\mathrm{P})$ \\
\hline $244.5(\mathrm{P})$ \\
\hline $1053.5(P)$ \\
\hline $7986.8(\mathrm{P})$ \\
\hline $822.3(\mathrm{P})$ \\
\hline $537(P)$ \\
\hline $1033.2(P)$ \\
\hline $203.9(P)$ \\
\hline $195.8(\mathrm{P})$ \\
\hline $258.7(P)$ \\
\hline $5269.5(\mathrm{P})$ \\
\hline $789.3(\mathrm{P})$ \\
\hline $210.3(P)$ \\
\hline $426.1(\mathrm{P})$ \\
\hline $583(P)$ \\
\hline $154.2(\mathrm{P})$ \\
\hline $758.5(\mathrm{P})$ \\
\hline $638.7(\mathrm{P})$ \\
\hline $4646.4(\mathrm{P})$ \\
\hline $866.5(P)$ \\
\hline $635.5(P)$ \\
\hline $451.2(\mathrm{P})$ \\
\hline $741.1(\mathrm{P})$ \\
\hline $6597.1(P)$ \\
\hline $393.4(\mathrm{P})$ \\
\hline 709.7 (P) \\
\hline $510.9(\mathrm{P})$ \\
\hline $554.2(\mathrm{P})$ \\
\hline $335.2(\mathrm{P})$ \\
\hline $4841(P)$ \\
\hline $824.8(\mathrm{P})$ \\
\hline $1557.5(\mathrm{P})$ \\
\hline $10945.8(P)$ \\
\hline $2515.8(P)$ \\
\hline $360.8(\mathrm{P})$ \\
\hline $1548.3(P)$ \\
\hline $867(P)$ \\
\hline $1736.5(\mathrm{P})$ \\
\hline $2885.2(P)$ \\
\hline $7106.4(\mathrm{P})$ \\
\hline $16082.8(\mathrm{P})$ \\
\hline $110.3(P)$ \\
\hline $6226.2(P)$ \\
\hline $5469.9(\mathrm{P})$ \\
\hline $477.3(\mathrm{P})$ \\
\hline $546.9(\mathrm{P})$ \\
\hline $119.3(\mathrm{P})$ \\
\hline $133.3(\mathrm{P})$ \\
\hline $2135(P)$ \\
\hline $14598.1(\mathrm{P})$ \\
\hline $7181.6(\mathrm{P})$ \\
\hline $3620.6(P)$ \\
\hline
\end{tabular}

\begin{tabular}{|c|c|}
\hline $639.5(P)$ & 12.13 \\
\hline $19.7(\mathrm{~A})$ & 12.13 \\
\hline $16.7(\mathrm{~A})$ & 12.13 \\
\hline $19(\mathrm{~A})$ & 13 \\
\hline $80.1(\mathrm{~A})$ & 13 \\
\hline $454.7(\mathrm{~A})$ & 13 \\
\hline $103.3(\mathrm{~A})$ & 13 \\
\hline $24(\mathrm{~A})$ & 13 \\
\hline $33.8(\mathrm{~A})$ & 13 \\
\hline $22.5(\mathrm{~A})$ & 13.93 \\
\hline $16.8(\mathrm{~A})$ & 13.93 \\
\hline $25.4(\mathrm{~A})$ & 13.93 \\
\hline $333.4(\mathrm{P})$ & 13.93 \\
\hline $51.9(\mathrm{~A})$ & 13.93 \\
\hline $16.1(\mathrm{~A})$ & 14.93 \\
\hline $28.4(\mathrm{~A})$ & 14.93 \\
\hline $31(\mathrm{~A})$ & 14.93 \\
\hline $10.6(\mathrm{~A})$ & 14.93 \\
\hline $32(\mathrm{~A})$ & 14.93 \\
\hline $33.7(\mathrm{~A})$ & 14.93 \\
\hline $263(\mathrm{~A})$ & 14.93 \\
\hline $44.7(\mathrm{~A})$ & 16 \\
\hline $12.6(\mathrm{~A})$ & 16 \\
\hline $31.5(\mathrm{~A})$ & 16 \\
\hline $24.4(\mathrm{~A})$ & 17.15 \\
\hline $185.7(\mathrm{~A})$ & 17.15 \\
\hline $22.3(\mathrm{~A})$ & 17.15 \\
\hline $44.2(\mathrm{~A})$ & 17.15 \\
\hline $16.8(\mathrm{~A})$ & 18.38 \\
\hline $25.1(\mathrm{~A})$ & 18.38 \\
\hline $25(\mathrm{~A})$ & 19.7 \\
\hline $138.5(\mathrm{~A})$ & 21.11 \\
\hline $18.7(\mathrm{~A})$ & 21.11 \\
\hline $27(\mathrm{~A})$ & 22.63 \\
\hline $264.4(\mathrm{P})$ & 22.63 \\
\hline $64.9(\mathrm{~A})$ & 22.63 \\
\hline $19.6(\mathrm{~A})$ & 24.25 \\
\hline $31(\mathrm{~A})$ & 24.25 \\
\hline $30(\mathrm{~A})$ & 24.25 \\
\hline $20.8(\mathrm{~A})$ & 25.99 \\
\hline $73.5(\mathrm{~A})$ & 27.86 \\
\hline $144.3(\mathrm{~A})$ & 27.86 \\
\hline $582.6(\mathrm{M})$ & 27.86 \\
\hline $6.4(\mathrm{~A})$ & 27.86 \\
\hline $204.5(\mathrm{~A})$ & 29.86 \\
\hline $207.3(\mathrm{~A})$ & 32 \\
\hline $23.8(\mathrm{~A})$ & 42.22 \\
\hline $14.5(\mathrm{~A})$ & 42.22 \\
\hline $4.3(\mathrm{~A})$ & 45.25 \\
\hline $6.8(\mathrm{~A})$ & 45.25 \\
\hline $17.1(\mathrm{~A})$ & 51.98 \\
\hline $108.3(\mathrm{~A})$ & 55.72 \\
\hline $68.5(\mathrm{~A})$ & 119.43 \\
\hline $28.2(\mathrm{~A})$ & 128 \\
\hline
\end{tabular}


"P"=Present-statistically greater than background intensity values "A"=Absent-not statistically different than background intensity values

"M"=Marginal-possibly different than bacground intensity values 


\begin{tabular}{|c|c|c|c|}
\hline Gene & $\begin{array}{c}\text { Densitometry \% Adjusted Volume } \\
\text { for Normal Lens RNA } \\
\end{array}$ & $\begin{array}{c}\text { Densitometry \% Adjusted Volume } \\
\text { for Cataractous Lens RNA } \\
\end{array}$ & $\begin{array}{l}\text { Fold Change } \\
\text { in Cataracts }\end{array}$ \\
\hline$\alpha \mathrm{B}$-crystallin & 21.62 & 17.52 & Decreased 1.23 Fold \\
\hline Catalase & 26.55 & 18.38 & Decreased 1.44 Fold \\
\hline MTF-1 & 22.29 & 24.46 & Increased 1.10 Fold \\
\hline
\end{tabular}

Primary Confirmations (Figure 3A)

\begin{tabular}{|c|c|c|c|}
\hline Gene & $\begin{array}{c}\text { Densitometry \% Adjusted Volume } \\
\text { for Normal Lens RNA } \\
\end{array}$ & $\begin{array}{c}\text { Densitometry \% Adjusted Volume } \\
\text { for Cataractous Lens RNA } \\
\end{array}$ & $\begin{array}{l}\text { Fold Change } \\
\text { in Cataracts }\end{array}$ \\
\hline Hsp27-1 & 72.35 & 27.65 & Decreased 2.62 Fold \\
\hline$\alpha \mathrm{A}-$ crystallin & 78.27 & 21.73 & Decreased 3.60 Fold \\
\hline RPL13a & 60.37 & 39.63 & Decreased 1.52 Fold \\
\hline Metallothionein IF & 74.11 & 25.89 & Decreased 2.86 Fold \\
\hline Metallothionein IH & 86.92 & 13.08 & Decreased 6.65 Fold \\
\hline Metallothionein IG & 86.05 & 13.95 & Decreased 6.17 Fold \\
\hline Glutathione Peroxidase 1 & 60.98 & 39.02 & Decreased 1.56 Fold \\
\hline $\mathrm{Na}+/ \mathrm{H}+$ Exchanger II & 17.2 & 82.8 & Increased 4.81 Fold \\
\hline Serine/Threonine Protein Kinase & 40.96 & 59.04 & Increased 1.44 Fold \\
\hline $\mathrm{Na}+/ \mathrm{K}+$ ATPase & 52.73 & 47.27 & Decreased 1.12 Fold \\
\hline Secreted Apoptosis Related Protein & 17.78 & 82.22 & Increased 4.62 Fold \\
\hline Pleiotrophin & 33.67 & 66.33 & Increased 1.97 Fold \\
\hline E3-Ubiquitin Ligase & 34.84 & 65.16 & Increased 1.87 Fold \\
\hline
\end{tabular}

Secondary Confirmations (Figure 3B)

$$
\text { Gene }
$$

Densitometry \% Adjusted Volume for Normal Lens RNA
Densitometry \% Adjusted Volume for Cataractous Lens RNA
Fold Change in Cataracts

$\begin{array}{lccc}\alpha \mathrm{A}-\text { crystallin } & 57.21 & 42.79 & \text { Decreased } 1.34 \text { Fold } \\ \text { RPL13a } & 54.29 & 45.71 & \text { Decreased } 1.19 \text { Fold } \\ \text { Metallothionein IF } & 67.16 & 32.84 & \text { Decreased } 2.05 \text { Fold } \\ \text { Na+/H+ Exchanger II } & 6.99 & 93.01 & \text { Increased } 13.31 \text { Fold } \\ \text { Serine/Threonine Protein Kinase } & 22.86 & 77.14 & \text { Increased } 3.37 \text { Fold } \\ \text { Na+/K+ ATPase } & 2.03 & 97.97 & \text { Increased } 48.26 \text { Fold } \\ \text { Pleiotrophin } & 14.78 & 85.22 & \text { Increased 5.77 Fold }\end{array}$

Tertiary Confirmations (Figure 4)

$$
\text { Gene }
$$

Densitometry \% Adjusted Volume

for Normal Lens RNA

HSP27-1

HSP27-2
34.74
Densitometry \% Adjusted Volume

for Cataractous Lens RNA
Fold Change

in Cataracts 
Table 4. Individual functionally clustered genes

\section{INCREASED in CATARACT}

\begin{tabular}{|c|c|c|c|}
\hline Category & Gene Name & Access. \# & Fold-change \\
\hline \multicolumn{4}{|l|}{ Biological Process } \\
\hline \multicolumn{4}{|l|}{ Chromosome Organization } \\
\hline & high-mobility group (nonhistone chromosomal) protein 1 & NM_002128 & 4.5948 \\
\hline & retinoblastoma-binding protein 1 (RBBP1) & NM_002892 & 4.9246 \\
\hline & alpha thalassemiamental retardation syndrome X-linked & NM_000489 & 5.6569 \\
\hline & chondroitin sulfate proteoglycan 6 (bamacan) & NM_005445 & 8.5742 \\
\hline & heterochromatin protein homologue (HP1) & NM_012117 & 4.0000 \\
\hline \multicolumn{4}{|l|}{ Nuclear Organization } \\
\hline & high-mobility group (nonhistone chromosomal) protein 1 & NM_002128 & 4.5948 \\
\hline & retinoblastoma-binding protein 1 (RBBP1) & NM_002892 & 4.9246 \\
\hline & alpha thalassemiamental retardation syndrome X-linked & NM_000489 & 5.6569 \\
\hline & chondroitin sulfate proteoglycan 6 (bamacan) & NM_005445 & 8.5742 \\
\hline & heterochromatin protein homologue (HP1) & NM_012117 & 4.0000 \\
\hline \multicolumn{4}{|l|}{ Transcription/DNA-Dependent } \\
\hline & high-mobility group (nonhistone chromosomal) protein 1 & NM_002128 & 4.5948 \\
\hline & Sjogren syndrome antigen B & NM_003142 & 6.4980 \\
\hline & zinc finger protein 161 & NM_007146 & 6.9644 \\
\hline & nuclear receptor interacting protein 1 & NM_003489 & 7.4643 \\
\hline & cofactor required for $\mathrm{Sp} 1$ transcriptional activation, subunit 2 & NM_004229 & 16.0000 \\
\hline & transcription termination factor, RNA polymerase I & NM_007344 & 4.0000 \\
\hline & retinoblastoma-binding protein 1 (RBBP1) & NM_002892 & 4.9246 \\
\hline & inhibitor of growth family, member 3 & NM_019071 & 4.2871 \\
\hline & small nuclear RNA activating complex & NM_003082 & 6.9644 \\
\hline & E3 ubiquitin ligase Smurf2 & NM_022739 & 4.5948 \\
\hline & homeo box A7 & NM_006896 & 4.2871 \\
\hline & nuclear factor of activated T-cells 5 & NM_006599 & 4.2871 \\
\hline & alpha thalassemiamental retardation syndrome X-linked & NM_000489 & 5.6569 \\
\hline & ubinuclein 1 & $\mathrm{~T} 70262$ & 5.6569 \\
\hline & erythroid-specific transcription factor & NM_006563 & 5.2780 \\
\hline & myeloidlymphoid or mixed-lineage leukemia & NM_005933 & 19.6983 \\
\hline
\end{tabular}




\begin{tabular}{|c|c|c|c|}
\hline & KIAA0876 protein & AW237172 & 6.9644 \\
\hline \multirow[t]{19}{*}{ Transcription } & & & \\
\hline & high-mobility group (nonhistone chromosomal) protein 1 & NM_002128 & 4.5948 \\
\hline & Sjogren syndrome antigen B & NM_003142 & 6.4980 \\
\hline & nuclear phosphoprotein & NM_007062 & 5.2780 \\
\hline & zinc finger protein 161 & NM_007146 & 6.9644 \\
\hline & nuclear receptor interacting protein 1 & NM_003489 & 7.4643 \\
\hline & cofactor required for $\mathrm{Sp} 1$ transcriptional activation, subunit 2 & NM_004229 & 16.0000 \\
\hline & transcription termination factor, RNA polymerase I & NM_007344 & 4.0000 \\
\hline & retinoblastoma-binding protein 1 (RBBP1) & NM_002892 & 4.9246 \\
\hline & inhibitor of growth family, member 3 & NM_019071 & 4.2871 \\
\hline & small nuclear RNA activating complex & NM_003082 & 6.9644 \\
\hline & E3 ubiquitin ligase Smurf2 & NM_022739 & 4.5948 \\
\hline & homeo box A7 & NM_006896 & 4.2871 \\
\hline & nuclear factor of activated T-cells 5 & NM_006599 & 4.2871 \\
\hline & alpha thalassemiamental retardation syndrome X-linked & NM_000489 & 5.6569 \\
\hline & ubinuclein 1 & T70262 & 5.6569 \\
\hline & erythroid-specific transcription factor & NM_006563 & 5.2780 \\
\hline & myeloidlymphoid or mixed-lineage leukemia & NM_005933 & 19.6983 \\
\hline & KIAA0876 protein & AW237172 & 6.9644 \\
\hline \multicolumn{4}{|l|}{ Nucleic Acid Metabolism } \\
\hline & high-mobility group (nonhistone chromosomal) protein 1 & NM_002128 & 4.5948 \\
\hline & Sjogren syndrome antigen B & NM_003142 & 6.4980 \\
\hline & nuclear phosphoprotein & NM_007062 & 5.2780 \\
\hline & zinc finger protein 161 & NM_007146 & 6.9644 \\
\hline & nuclear receptor interacting protein 1 & NM_003489 & 7.4643 \\
\hline & cofactor required for $\mathrm{Sp} 1$ transcriptional activation, subunit 2 & NM_004229 & 16.0000 \\
\hline & Nijmegen breakage syndrome 1 (nibrin) & NM_002485 & 6.9644 \\
\hline & transcription termination factor, RNA polymerase I & NM_007344 & 4.0000 \\
\hline & retinoblastoma-binding protein 1 (RBBP1) & NM_002892 & 4.9246 \\
\hline & inhibitor of growth family, member 3 & NM_019071 & 4.2871 \\
\hline & small nuclear RNA activating complex & NM_003082 & 6.9644 \\
\hline & E3 ubiquitin ligase Smurf2 & NM_022739 & 4.5948 \\
\hline & homeo box A7 & NM_006896 & 4.2871 \\
\hline & nuclear factor of activated T-cells 5 & NM_006599 & 4.2871 \\
\hline & cisplatin resistance-associated overexpressed protein & AW089673 & 4.2871 \\
\hline & alpha thalassemiamental retardation syndrome X-linked & NM_000489 & 5.6569 \\
\hline & NS1-associated protein 1 & AF037448 & 4.9246 \\
\hline
\end{tabular}




\begin{tabular}{|c|c|c|c|}
\hline & ubinuclein 1 & $\mathrm{~T} 70262$ & 5.6569 \\
\hline & methyl-CpG binding domain protein 4 & NM_003925 & 4.2871 \\
\hline & heterochromatin protein homologue (HP1) & NM_012117 & 4.0000 \\
\hline & erythroid-specific transcription factor & NM_006563 & 5.2780 \\
\hline & myeloidlymphoid or mixed-lineage leukemia & NM_005933 & 19.6983 \\
\hline & KIAA0876 protein & AW237172 & 6.9644 \\
\hline \multicolumn{4}{|l|}{ Molecular Function } \\
\hline \multicolumn{4}{|l|}{ Nucleic Acid Binding } \\
\hline & high-mobility group (nonhistone chromosomal) protein 1 & NM_002128 & 4.5948 \\
\hline & Sjogren syndrome antigen B & NM_003142 & 6.4980 \\
\hline & fragile $\mathrm{X}$ mental retardation, autosomal homolog 1 & NM_005087 & 4.5948 \\
\hline & zinc finger protein 161 & NM_007146 & 6.9644 \\
\hline & cofactor required for Sp1 transcriptional activation, subunit 2 & NM_004229 & 16.0000 \\
\hline & Nijmegen breakage syndrome 1 (nibrin) & NM_002485 & 6.9644 \\
\hline & ring finger protein 15 & NM_006355 & 19.6983 \\
\hline & transcription termination factor, RNA polymerase I & NM_007344 & 4.0000 \\
\hline & retinoblastoma-binding protein 1 (RBBP1) & NM_002892 & 4.9246 \\
\hline & inhibitor of growth family, member 3 & NM_019071 & 4.2871 \\
\hline & homeo box A7 & NM_006896 & 4.2871 \\
\hline & nuclear factor of activated T-cells 5 & NM_006599 & 4.2871 \\
\hline & lymphoid blast crisis oncogene & NM_006738 & 4.2871 \\
\hline & eukaryotic translation initiation factor 4 gamma & AF104913 & 6.4980 \\
\hline & alpha thalassemiamental retardation syndrome X-linked & NM_000489 & 5.6569 \\
\hline & NS1-associated protein 1 & AF037448 & 4.9246 \\
\hline & ubinuclein 1 & $\mathrm{~T} 70262$ & 5.6569 \\
\hline & methyl-CpG binding domain protein 4 & NM_003925 & 4.2871 \\
\hline & heterochromatin protein homologue (HP1) & NM_012117 & 4.0000 \\
\hline & erythroid-specific transcription factor & NM_006563 & 5.2780 \\
\hline & myeloidlymphoid or mixed-lineage leukemia & NM_005933 & 19.6983 \\
\hline & KIAA0876 protein & AW237172 & 6.9644 \\
\hline \multicolumn{4}{|l|}{ Ligand Binding or Carrier } \\
\hline & high-mobility group (nonhistone chromosomal) protein 1 & NM_002128 & 4.5948 \\
\hline & Sjogren syndrome antigen B & NM_003142 & 6.4980 \\
\hline & ATPase, $\mathrm{Na}+\mathrm{K}+$ transporting, beta 1 & $\mathrm{BC} 000006$ & 8.0000 \\
\hline & fragile X mental retardation, autosomal homolog 1 & NM_005087 & 4.5948 \\
\hline
\end{tabular}




\begin{tabular}{|c|c|c|}
\hline RAN binding protein 2 & NM_006267 & 4.5948 \\
\hline adducin 3 (gamma) & NM_019903 & 6.0629 \\
\hline KIAA0494 gene product & NM_014774 & 17.1484 \\
\hline SEC14 & NM_003003 & 4.9246 \\
\hline copine III & NM_003909 & 6.9644 \\
\hline zinc finger protein 161 & NM_007146 & 6.9644 \\
\hline nuclear receptor interacting protein 1 & NM_003489 & 7.4643 \\
\hline cofactor required for Sp1 transcriptional activation, subunit 2 & NM_004229 & 16.0000 \\
\hline glutathione peroxidase 2 & NM_002083 & 8.0000 \\
\hline Nijmegen breakage syndrome 1 (nibrin) & NM_002485 & 6.9644 \\
\hline ring finger protein 15 & NM_006355 & 19.6983 \\
\hline transcription termination factor, RNA polymerase I & NM_007344 & 4.0000 \\
\hline retinoblastoma-binding protein 1 (RBBP1) & NM_002892 & 4.9246 \\
\hline inhibitor of growth family, member 3 & NM_019071 & 4.2871 \\
\hline Wiskott-Aldrich syndrome-like & NM_003941 & 14.9285 \\
\hline homeo box A7 & NM_006896 & 4.2871 \\
\hline neurotrophic tyrosine kinase, receptor, type 2 & NM_006180 & 4.0000 \\
\hline nuclear factor of activated T-cells 5 & NM_006599 & 4.2871 \\
\hline lymphoid blast crisis oncogene & NM_006738 & 4.2871 \\
\hline eukaryotic translation initiation factor 4 gamma & AF104913 & 6.4980 \\
\hline alpha thalassemiamental retardation syndrome $\mathrm{X}$-linked & NM_000489 & 5.6569 \\
\hline NS1-associated protein 1 & $\mathrm{AF} 037448$ & 4.9246 \\
\hline ubinuclein 1 & $\mathrm{~T} 70262$ & 5.6569 \\
\hline chondroitin sulfate proteoglycan 6 (bamacan) & NM_005445 & 8.5742 \\
\hline pleiotrophin & M57399 & 7.4643 \\
\hline methyl-CpG binding domain protein 4 & NM_003925 & 4.2871 \\
\hline heterochromatin protein homologue (HP1) & NM_012117 & 4.0000 \\
\hline erythroid-specific transcription factor & NM_006563 & 5.2780 \\
\hline myeloidlymphoid or mixed-lineage leukemia & NM_005933 & 19.6983 \\
\hline KIAA0876 protein & AW237172 & 6.9644 \\
\hline KIAA0594 protein & AW183677 & 9.1896 \\
\hline Ser-Thr protein kinase & NM_003607 & 6.4980 \\
\hline calcium channel, voltage-dependent, PQ type, alpha $1 \mathrm{~A}$ & AA769818 & 4.9246 \\
\hline high-mobility group (nonhistone chromosomal) protein 1 & NM_002128 & 4.5948 \\
\hline zinc finger protein 161 & NM_007146 & 6.9644 \\
\hline cofactor required for Sp1 transcriptional activation, subunit 2 & NM_004229 & 16.0000 \\
\hline Nijmegen breakage syndrome 1 (nibrin) & NM_002485 & 6.9644 \\
\hline
\end{tabular}




\begin{tabular}{|l|l|l|}
\hline transcription termination factor, RNA polymerase I & NM_007344 & 4.0000 \\
\hline retinoblastoma-binding protein 1 (RBBP1) & NM_002892 & 4.9246 \\
\hline inhibitor of growth family, member 3 & NM_019071 & 4.2871 \\
\hline homeo box A7 & NM_006896 & 4.2871 \\
\hline nuclear factor of activated T-cells 5 & NM_006599 & 4.2871 \\
\hline alpha thalassemiamental retardation syndrome X-linked & NM_000489 & 5.6569 \\
\hline ubinuclein 1 & T70262 & 5.6569 \\
\hline methyl-CpG binding domain protein 4 & NM_003925 & 4.2871 \\
\hline heterochromatin protein homologue (HP1) & NM_012117 & 4.0000 \\
\hline erythroid-specific transcription factor & NM_006563 & 5.2780 \\
\hline myeloidlymphoid or mixed-lineage leukemia & NM_005933 & 19.6983 \\
\hline KIAA0876 protein & AW237172 & 6.9644 \\
\hline
\end{tabular}

\begin{tabular}{|c|c|c|c|}
\hline \multicolumn{4}{|l|}{ Decreased in Cataract } \\
\hline Category & Gene Name & Access. \# & Fold-Change \\
\hline \multicolumn{4}{|l|}{ Biological Process } \\
\hline \multicolumn{4}{|l|}{ RNA Splicing } \\
\hline & small nuclear ribonucleoprotein D2 polypeptide & NM_004597 & 4.5948 \\
\hline & splicing factor, arginineserine-rich 9 & NM_003769 & 6.0629 \\
\hline & small nuclear ribonucleoprotein D3 polypeptide & NM_004175 & 4.5948 \\
\hline & U6 snRNA-associated Sm-like protein LSm7 & NM_016199 & 10.5561 \\
\hline & putative mitochondrial outer membrane protein import receptor & AB019219 & 4.5948 \\
\hline & SMX5-like protein & AF196468 & 5.6569 \\
\hline \multicolumn{4}{|l|}{ Protein Biosynthesis } \\
\hline & eukaryotic translation initiation factor 3 , subunit 7 & NM_003753 & 4.9246 \\
\hline & eukaryotic translation elongation factor 1 gamma & NM_001404 & 10.5561 \\
\hline & poly(A)-binding protein, cytoplasmic 4 & NM_003819 & 6.9644 \\
\hline & threonyl-tRNA synthetase & NM_003191 & 6.0629 \\
\hline & eukaryotic translation initiation factor $4 \mathrm{~A}$, isoform 1 & NM_001416 & 4.2871 \\
\hline & eukaryotic translation initiation factor $2 \mathrm{~B}$, subunit 1 & NM_001414 & 6.0629 \\
\hline & heat shock $27 \mathrm{kD}$ protein 1 & NM_001540 & 128.0000 \\
\hline & SUI1 isolog & AF083441 & 4.5948 \\
\hline & histidyl-tRNA synthetase & NM_002109 & 12.9960 \\
\hline
\end{tabular}




\begin{tabular}{|c|c|c|c|}
\hline & eukaryotic translation elongation factor 1 delta & NM_001960 & 6.4980 \\
\hline & growth arrest and DNA-damage-inducible, alpha & NM_001924 & 24.2515 \\
\hline & eukaryotic translation elongation factor 2 & NM_001961 & 21.1121 \\
\hline & ribosomal protein, large, $\mathrm{P} 0$ & $\mathrm{BC} 003655$ & 4.5948 \\
\hline & eukaryotic translation initiation factor 3 , subunit 4 & $\mathrm{BC} 000733$ & 8.0000 \\
\hline & translation initiation factor 6 & AF022229 & 4.0000 \\
\hline \multirow[t]{5}{*}{ Protein Synthesis Elongation } & & & \\
\hline & eukaryotic translation elongation factor 1 gamma & NM_001404 & 10.5561 \\
\hline & eukaryotic translation elongation factor 1 delta & NM_001960 & 6.4980 \\
\hline & eukaryotic translation elongation factor 2 & NM_001961 & 21.1121 \\
\hline & ribosomal protein, large, $\mathrm{P} 0$ & $\mathrm{BC} 003655$ & 4.5948 \\
\hline \multicolumn{4}{|l|}{ Protein Synthesis Initiation } \\
\hline & eukaryotic translation initiation factor $4 \mathrm{~A}$, isoform 1 & NM_001416 & 4.2871 \\
\hline & eukaryotic translation initiation factor $2 \mathrm{~B}$, subunit 1 & NM_001414 & 6.0629 \\
\hline & SUI1 isolog & AF083441 & 4.5948 \\
\hline & translation initiation factor 6 & AF022229 & 4.0000 \\
\hline \multicolumn{4}{|l|}{ Macromolecule Biosynthesis } \\
\hline & eukaryotic translation initiation factor 3 , subunit 7 & NM_003753 & 4.9246 \\
\hline & eukaryotic translation elongation factor 1 gamma & NM_001404 & 10.5561 \\
\hline & poly(A)-binding protein, cytoplasmic 4 & NM_003819 & 6.9644 \\
\hline & threonyl-tRNA synthetase & NM_003191 & 6.0629 \\
\hline & eukaryotic translation initiation factor $4 \mathrm{~A}$, isoform 1 & NM_001416 & 4.2871 \\
\hline & eukaryotic translation initiation factor $2 \mathrm{~B}$, subunit 1 & NM_001414 & 6.0629 \\
\hline & heat shock $27 \mathrm{kD}$ protein 1 & NM_001540 & 128.0000 \\
\hline & SUI1 isolog & $\mathrm{AF} 083441$ & 4.5948 \\
\hline & histidyl-tRNA synthetase & NM_002109 & 12.9960 \\
\hline & eukaryotic translation elongation factor 1 delta & NM_001960 & 6.4980 \\
\hline & growth arrest and DNA-damage-inducible, alpha & NM_001924 & 24.2515 \\
\hline & eukaryotic translation elongation factor 2 & NM_001961 & 21.1121 \\
\hline & ribosomal protein, large, $\mathrm{P} 0$ & $\mathrm{BC} 003655$ & 4.5948 \\
\hline & eukaryotic translation initiation factor 3 , subunit 4 & $\mathrm{BC} 000733$ & 8.0000 \\
\hline & translation initiation factor 6 & AF022229 & 4.0000 \\
\hline \multicolumn{4}{|l|}{ Amine Biosynthesis } \\
\hline & ornithine decarboxylase 1 & NM_002539 & 4.9246 \\
\hline & antizyme inhibitor & NM 015878 & 6.9644 \\
\hline & phosphatidylethanolamine N-methyltransferase & NM_007169 & 6.0629 \\
\hline
\end{tabular}




\begin{tabular}{|c|c|c|c|}
\hline \multirow[t]{5}{*}{ Peroxidase Reaction } & & & \\
\hline & glutathione peroxidae 1 (GPX1) & NM_000581 & 4.9246 \\
\hline & glutathione peroxidase 4 (phospholipid hydroperoxidase) & NM_002085 & 4.2871 \\
\hline & glutathione peroxidase 3 (GPX3) & NM_002084 & 11.3137 \\
\hline & KIAA0230 gene & D86983 & 12.1257 \\
\hline \multicolumn{4}{|c|}{ Microtubule-Based Process } \\
\hline & microtubule-associated protein, RPEB family, member 1 & AI633566 & 10.5561 \\
\hline & GTP binding protein & $\mathrm{AF} 054183$ & 4.9246 \\
\hline & spindle pole body protein (GCP3) & NM_006322 & 9.1896 \\
\hline & microtubule-associated protein like echinoderm EMAP & NM_012155 & 4.9246 \\
\hline & retinitis pigmentosa 2 & NM_006915 & 12.1257 \\
\hline & microtubule-associated proteins $1 \mathrm{~A} 1 \mathrm{~B}$ light chain 3 & AF183417 & 5.6569 \\
\hline & tubulin, beta, 2 & $\mathrm{BC} 004188$ & 6.0629 \\
\hline & Similar to tubulin, beta, 4 & $\mathrm{BC} 002654$ & 7.4643 \\
\hline \multicolumn{4}{|l|}{ Organelle Organization } \\
\hline & microtubule-associated protein, RPEB family, member 1 & AI633566 & 10.5561 \\
\hline & GTP binding protein & AF054183 & 4.9246 \\
\hline & saposin proteins A-D & M32221 & 18.3800 \\
\hline & peroxisomal farnesylated protein & NM_002857 & 4.0000 \\
\hline & translocase of inner mitochondrial membrane 17 & BC004439 & 9.1896 \\
\hline & spindle pole body protein (GCP3) & NM_006322 & 9.1896 \\
\hline & microtubule-associated protein like echinoderm EMAP & NM_012155 & 4.9246 \\
\hline & retinitis pigmentosa 2 & NM_006915 & 12.1257 \\
\hline & microtubule-associated proteins 1A1B light chain 3 & AF183417 & 5.6569 \\
\hline & tubulin, beta, 2 & BC004188 & 6.0629 \\
\hline & Similar to tubulin, beta, 4 & $\mathrm{BC} 002654$ & 7.4643 \\
\hline \multicolumn{4}{|c|}{ Cytoskeleton Organization } \\
\hline & microtubule-associated protein, RPEB family, member 1 & AI633566 & 10.5561 \\
\hline & GTP binding protein & AF054183 & 4.9246 \\
\hline & spindle pole body protein (GCP3) & NM_006322 & 9.1896 \\
\hline & microtubule-associated protein like echinoderm EMAP & NM_012155 & 4.9246 \\
\hline & retinitis pigmentosa 2 & NM_006915 & 12.1257 \\
\hline & microtubule-associated proteins $1 \mathrm{~A} 1 \mathrm{~B}$ light chain 3 & AF183417 & 5.6569 \\
\hline & tubulin, beta, 2 & BC004188 & 6.0629 \\
\hline & Similar to tubulin, beta, 4 & $\mathrm{BC} 002654$ & 7.4643 \\
\hline \multicolumn{4}{|l|}{ Temperature Response } \\
\hline & isolate Liv chaperone protein $\mathrm{HSP} 90$ beta & AF275719 & 4.9246 \\
\hline & DnaJ (Hsp40) homolog, subfamily B, member 1 & BG537255 & 6.4980 \\
\hline
\end{tabular}




\begin{tabular}{|c|c|c|c|}
\hline & myeloid cell leukemia sequence 1 (BCL2-related) & AI275690 & 4.0000 \\
\hline & heat shock $70 \mathrm{kD}$ protein $1 \mathrm{~A}$ & NM_005345 & 4.0000 \\
\hline & cold shock domain protein $\mathrm{A}$ & NM_003651 & 5.6569 \\
\hline & heat shock $27 \mathrm{kD}$ protein 1 & NM_001540 & 128.0000 \\
\hline & heat shock $70 \mathrm{kD}$ protein $1 \mathrm{~B}$ & NM_005346 & 5.6569 \\
\hline & heat shock $27 \mathrm{kD}$ protein 2 & NM_001541 & 5.2780 \\
\hline \multirow[t]{8}{*}{ Heat Shock Response } & & & \\
\hline & isolate Liv chaperone protein $\mathrm{HSP} 90$ beta & AF275719 & 4.9246 \\
\hline & DnaJ (Hsp40) homolog, subfamily B, member 1 & BG537255 & 6.4980 \\
\hline & myeloid cell leukemia sequence 1 (BCL2-related) & AI275690 & 4.0000 \\
\hline & heat shock $70 \mathrm{kD}$ protein $1 \mathrm{~A}$ & NM_005345 & 4.0000 \\
\hline & heat shock $27 \mathrm{kD}$ protein 1 & NM_001540 & 128.0000 \\
\hline & heat shock $70 \mathrm{kD}$ protein $1 \mathrm{~B}$ & NM_005346 & 5.6569 \\
\hline & heat shock $27 \mathrm{kD}$ protein 2 & NM_001541 & 5.2780 \\
\hline \multicolumn{4}{|l|}{ Vision } \\
\hline & L-iditol-2 dehydrogenase & L29008 & 12.1257 \\
\hline & EGF-containing fibulin-like extracellular matrix protein 1 & AI826799 & 4.9246 \\
\hline & fibrillin 1 & NM_000138 & 5.2780 \\
\hline & microtubule-associated protein like echinoderm EMAP & NM_012155 & 4.9246 \\
\hline & retinitis pigmentosa 2 & NM_006915 & 12.1257 \\
\hline & beta B2 crystallin & NM_000496 & 6.4980 \\
\hline & beta A4 crystallin & NM_001886 & 168.8970 \\
\hline & phakinin, beaded filament structural protein 2 & NM_003571 & 12.9960 \\
\hline & gamma D crystallin & NM_006891 & 29.8571 \\
\hline & beta B3 crystallin & NM_004076 & 22.6274 \\
\hline \multicolumn{4}{|l|}{ Response to External Stimulus } \\
\hline & isolate Liv chaperone protein HSP90 beta & AF275719 & 4.9246 \\
\hline & DnaJ (Hsp40) homolog, subfamily B, member 1 & BG537255 & 6.4980 \\
\hline & myeloid cell leukemia sequence 1 (BCL2-related) & AI275690 & 4.0000 \\
\hline & heat shock $70 \mathrm{kD}$ protein $1 \mathrm{~A}$ & NM_005345 & 4.0000 \\
\hline & poly(A)-binding protein, cytoplasmic 4 & NM_003819 & 6.9644 \\
\hline & cold shock domain protein A & NM_003651 & 5.6569 \\
\hline & interferon induced transmembrane protein 2 & NM_006435 & 4.5948 \\
\hline & glutathione peroxidase 3 (GPX3) & NM_002084 & 11.3137 \\
\hline & L-iditol-2 dehydrogenase & L29008 & 12.1257 \\
\hline & heat shock $27 \mathrm{kD}$ protein 1 & NM_001540 & 128.0000 \\
\hline & EGF-containing fibulin-like extracellular matrix protein 1 & AI826799 & 4.9246 \\
\hline
\end{tabular}




\begin{tabular}{|c|c|c|c|}
\hline & beta-2-microglobulin & NM_004048 & 4.2871 \\
\hline & heat shock $70 \mathrm{kD}$ protein $1 \mathrm{~B}$ & NM_005346 & 5.6569 \\
\hline & interferon gamma receptor 1 & NM_000416 & 4.0000 \\
\hline & fibrillin 1 & NM_000138 & 5.2780 \\
\hline & growth arrest and DNA-damage-inducible, alpha & NM_001924 & 24.2515 \\
\hline & carbohydrate (chondroitin 6keratan) sulfotransferase 2 & NM_004267 & 4.5948 \\
\hline & microtubule-associated protein like echinoderm EMAP & NM_012155 & 4.9246 \\
\hline & cysteine-rich protein 1 & NM_001311 & 14.9285 \\
\hline & retinitis pigmentosa 2 & NM_006915 & 12.1257 \\
\hline & heat shock $27 \mathrm{kD}$ protein 2 & NM_001541 & 5.2780 \\
\hline & beta B2 crystallin & NM_000496 & 6.4980 \\
\hline & beta A4 crystallin & NM_001886 & 168.8970 \\
\hline & phakinin, beaded filament structural protein 2 & NM_003571 & 12.9960 \\
\hline & gamma $\mathrm{D}$ crystallin & NM_006891 & 29.8571 \\
\hline & beta B3 crystallin & NM_004076 & 22.6274 \\
\hline & CD24 antigen & BG327863 & 4.9246 \\
\hline & complement cytolysis inhibitor & M25915 & 4.2871 \\
\hline & pre-mRNA splicing factor $2 \mathrm{p} 32$ subunit & L04636 & 7.4643 \\
\hline & v-fos FBJ murine osteosarcoma viral oncogene homolog & $\mathrm{BC} 004490$ & 12.1257 \\
\hline & KIAA0230 gene & D86983 & 12.1257 \\
\hline & monocyte chemotactic protein & S69738 & 6.4980 \\
\hline \multicolumn{4}{|l|}{ Molecular Function } \\
\hline \multicolumn{4}{|l|}{ U6 snRNA Binding } \\
\hline & U6 snRNA-associated Sm-like protein LSm7 & NM_016199 & 10.5561 \\
\hline & SMX5-like protein & AF196468 & 5.6569 \\
\hline \multicolumn{4}{|l|}{ Pre-mRNA Splicing Factor } \\
\hline & small nuclear ribonucleoprotein D2 polypeptide & NM_004597 & 4.5948 \\
\hline & splicing factor, arginineserine-rich 9 & NM_003769 & 6.0629 \\
\hline & small nuclear ribonucleoprotein D3 polypeptide & NM_004175 & 4.5948 \\
\hline & U6 snRNA-associated Sm-like protein LSm7 & NM_016199 & 10.5561 \\
\hline & putative mitochondrial outer membrane protein import receptor & AB019219 & 4.5948 \\
\hline & U6 snRNA-associated Sm-like protein & AF196468 & 5.6569 \\
\hline \multicolumn{4}{|l|}{ mRNA Binding } \\
\hline & small nuclear ribonucleoprotein D2 polypeptide & NM_004597 & 4.5948 \\
\hline
\end{tabular}




\begin{tabular}{|c|c|c|c|}
\hline & poly(A)-binding protein, cytoplasmic 4 & NM_003819 & 6.9644 \\
\hline & eukaryotic translation initiation factor $4 \mathrm{~A}$, isoform 1 & NM_001416 & 4.2871 \\
\hline & splicing factor, arginineserine-rich 9 & NM_003769 & 6.0629 \\
\hline & small nuclear ribonucleoprotein D3 polypeptide & NM_004175 & 4.5948 \\
\hline & U6 snRNA-associated Sm-like protein LSm7 & NM_016199 & 10.5561 \\
\hline & putative mitochondrial outer membrane protein import receptor & AB019219 & 4.5948 \\
\hline & U6 snRNA-associated Sm-like protein & AF196468 & 5.6569 \\
\hline \multicolumn{4}{|l|}{ Proteasome Endopeptidase } \\
\hline & proteasome (prosome,macropain)subunit,beta type, 1 & NM_002799 & 6.0629 \\
\hline & proteasome (prosome,macropain)subunit,beta type, 1 & NM_002793 & 8.5742 \\
\hline & proteasome (prosome,macropain)subunit,alpa type, 3 & NM_002788 & 5.6569 \\
\hline & proteasome (prosome,macropain)subunit,beta type, 4 & NM_002796 & 5.2780 \\
\hline \multicolumn{4}{|l|}{ Translation Factor } \\
\hline & eukaryotic translation initiation factor 3 , subunit 7 & NM_003753 & 4.9246 \\
\hline & eukaryotic translation elongation factor 1 gamma & NM_001404 & 10.5561 \\
\hline & eukaryotic translation initiation factor $4 \mathrm{~A}$, isoform 1 & NM_001416 & 4.2871 \\
\hline & eukaryotic translation initiation factor $2 \mathrm{~B}$, subunit 1 & NM_001414 & 6.0629 \\
\hline & SUI1 isolog & $\mathrm{AF} 083441$ & 4.5948 \\
\hline & eukaryotic translation elongation factor 1 delta & NM_001960 & 6.4980 \\
\hline & eukaryotic translation elongation factor 2 & NM_001961 & 21.1121 \\
\hline & eukaryotic translation initiation factor 3 , subunit 4 & $\mathrm{BC} 000733$ & 8.0000 \\
\hline & translation initiation factor 6 & AF022229 & 4.0000 \\
\hline \multicolumn{4}{|l|}{ Selenium Binding } \\
\hline & glutathione peroxidase 1 & NM_000581 & 4.9246 \\
\hline & glutathione peroxidase 4 (phospholipid hydroperoxidase) & NM_002085 & 4.2871 \\
\hline & selenoprotein W, 1 (SEPW1) & NM_003009 & 6.4980 \\
\hline & glutathione peroxidase 3 (GPX3) & NM_002084 & 11.3137 \\
\hline \multicolumn{4}{|l|}{ Alcohol Dehydrogenase } \\
\hline & L-iditol-2 dehydrogenase & L29008 & 12.1257 \\
\hline & quinone oxidoreductase homolog & $\mathrm{BC} 000474$ & 11.3137 \\
\hline & beta3-Galactosyltransferase & AL031228 & 6.0629 \\
\hline \multicolumn{4}{|l|}{ Heat Shock Protein } \\
\hline & isolate Liv chaperone protein HSP90 beta & AF275719 & 4.9246 \\
\hline & DnaJ (Hsp40) homolog, subfamily B, member 1 & BG537255 & 6.4980 \\
\hline & heat shock $70 \mathrm{kD}$ protein $1 \mathrm{~A}$ & NM_005345 & 4.0000 \\
\hline & heat shock $27 \mathrm{kD}$ protein 1 & NM_001540 & 128.0000 \\
\hline & heat shock $70 \mathrm{kD}$ protein $1 \mathrm{~B}$ & NM_005346 & 5.6569 \\
\hline & heat shock $27 \mathrm{kD}$ protein 2 & NM_001541 & 5.2780 \\
\hline
\end{tabular}


Oxidoreductase

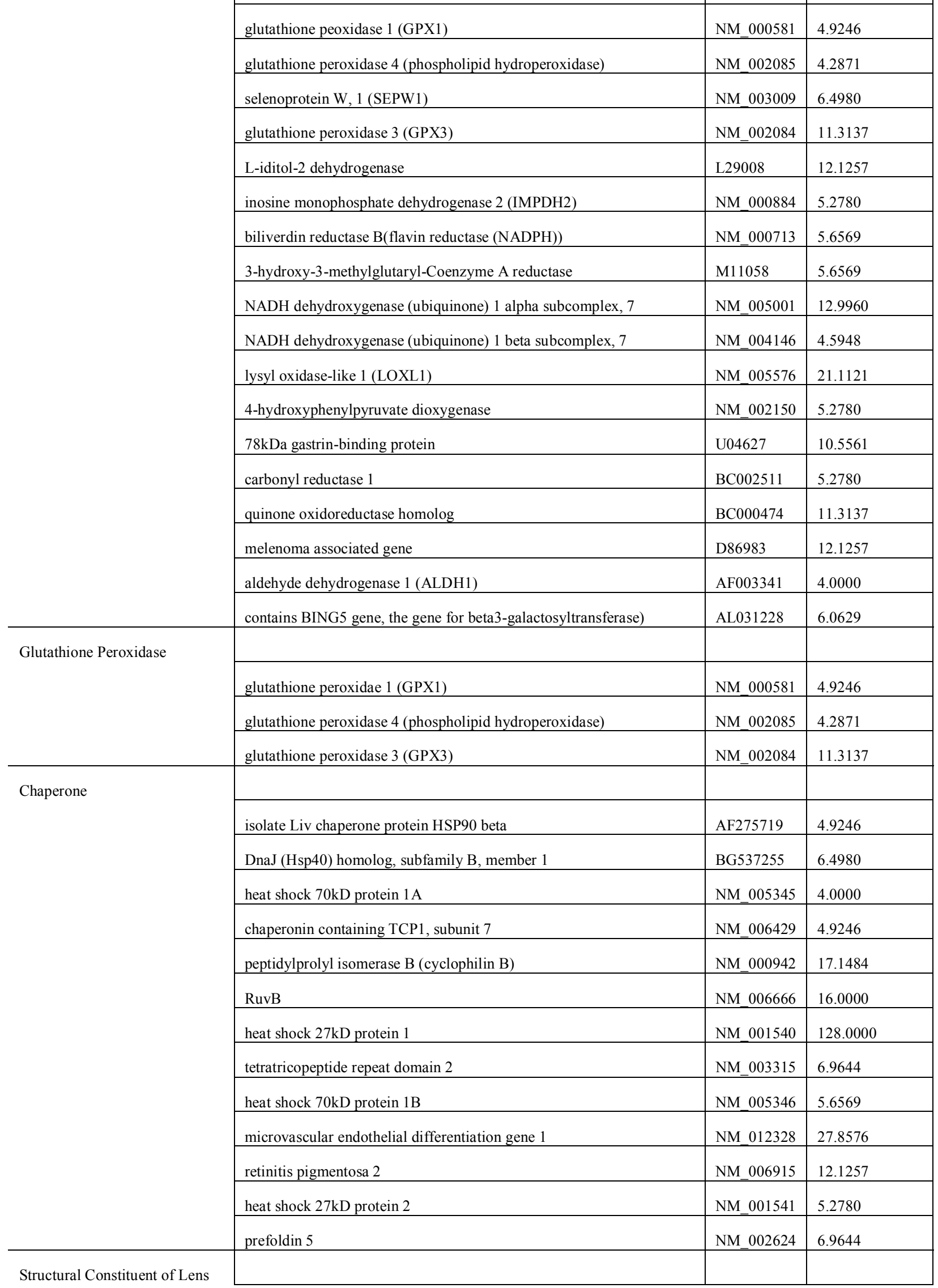




\begin{tabular}{|c|c|c|c|}
\hline & filensin, beaded filament structural protein 1 & NM_001195 & 17.1484 \\
\hline & beta B2 crystallin & NM_000496 & 6.4980 \\
\hline & beta B2 crystallin & NM_000496 & 12.1257 \\
\hline & beta A4 crystallin & NM_001886 & 168.8970 \\
\hline & phakinin, beaded filament structural protein 2 & NM_003571 & 12.9960 \\
\hline & gamma D crystallin & NM_006891 & 29.8571 \\
\hline & beta B3 crystallin & NM_004076 & 22.6274 \\
\hline & crystallin, gamma B & NM_005210 & 6.4980 \\
\hline \multicolumn{4}{|l|}{ Structural Molecule } \\
\hline & moesin & NM_002444 & 9.8492 \\
\hline & gelsolin & NM_000177 & 4.2871 \\
\hline & keratin 19 & NM_002276 & 4.9246 \\
\hline & nidogen (enactin) & BF940043 & 8.5742 \\
\hline & fibrillin 1 & NM_000138 & 5.2780 \\
\hline & spindle pole body protein & NM_006322 & 9.1896 \\
\hline & growth arrest and DNA-damage-inducible, alpha & NM_001924 & 24.2515 \\
\hline & catenin (cadherin-associated protein), alpha 2 & NM_004389 & 6.9644 \\
\hline & filensin, beaded filament structural protein 1 & NM_001195 & 17.1484 \\
\hline & beta B2 crystallin & NM_000496 & 6.4980 \\
\hline & beta B2 crystallin & NM_000496 & 12.1257 \\
\hline & beta A4 crystallin & NM_001886 & 168.8970 \\
\hline & phakinin, beaded filament structural protein 2 & NM_003571 & 12.9960 \\
\hline & gamma D crystallin & NM_006891 & 29.8571 \\
\hline & beta B3 crystallin & NM_004076 & 22.6274 \\
\hline & gamma B crystallin & NM_005210 & 6.4980 \\
\hline & alpha II spectrin & U83867 & 8.0000 \\
\hline & ribosomal protein, large, $\mathrm{P} 0$ & $\mathrm{BC} 003655$ & 4.5948 \\
\hline & tubulin, beta, 2 & BC004188 & 6.0629 \\
\hline & Similar to tubulin, beta, 4 & $\mathrm{BC} 002654$ & 7.4643 \\
\hline & tropomyosin & M19267 & 4.0000 \\
\hline & amyloid beta (A4) & X06989 & 4.0000 \\
\hline
\end{tabular}


Figure 1. Genes increased 2-fold or greater between cataract and clear lenses. The total number of genes included in each fold change category is indicated. Percentages indicated the total number of genes in each category relative to the total number of increased genes (412) on the chip. 


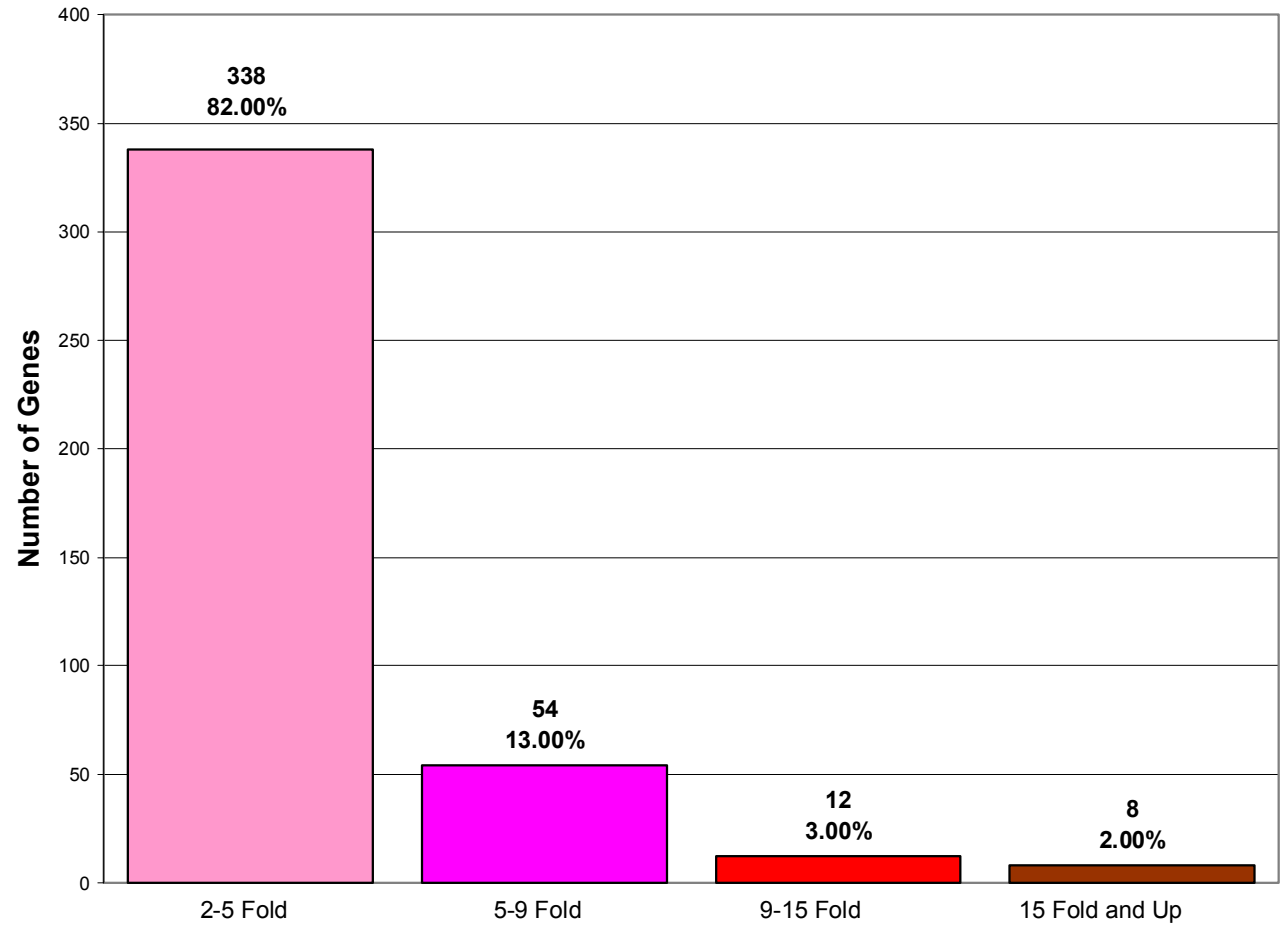

Fold Change Range 
Figure 2. Genes decreased 2-fold or greater between cataract and clear lenses. The total number of genes included in each fold change category is indicated. Percentages indicated the total number of genes in each category relative to the total number of decreased genes (919) on the chip. 


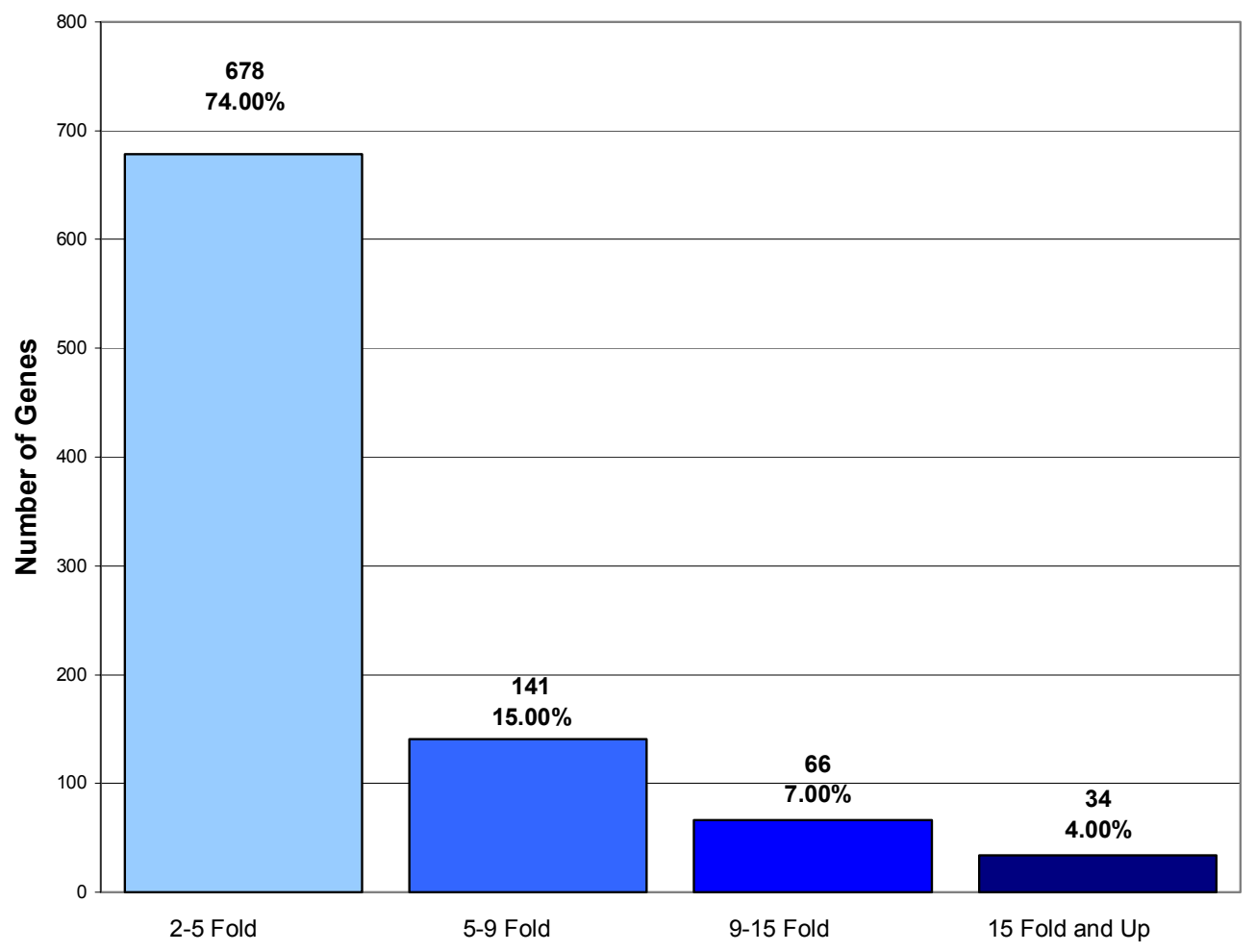

Fold Change Range 
Figure 3. RT-PCR confirmation of gene expression differences detected by microarray hybridization between cataract (C) and clear (N) lens epithelia. The expression levels of indicated genes were confirmed by RT-PCR. A). Genes examined using the same cataract and clear lens RNAs analyzed by microarray hybridization. B). Genes examined using separately prepared cataract and clear lens RNA samples. 


\section{Primary Confirmations}

Genes decreased in Cataract vs. Normal lenses

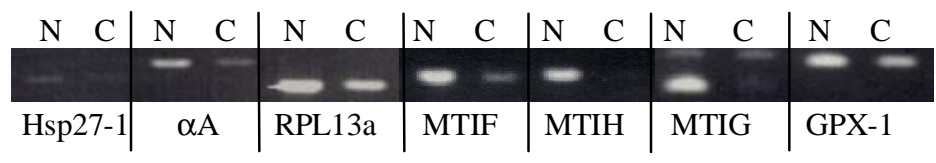

Genes increased in Cataract vs. Normal lenses

\begin{tabular}{|c|c|c|c|c|c|}
\hline C & $\mathrm{N}$ & $\mathrm{N} \quad \mathrm{C}$ & $\mathrm{N}$ & $\mathrm{N}$ & $\mathrm{N}$ \\
\hline 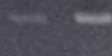 & -- & -- & - & -1 & $1--$ \\
\hline $\begin{array}{c}\mathrm{Na}+/ \mathrm{H} \\
\mathrm{Ex}\end{array}$ & & $\begin{array}{l}\mathrm{Na}+/ \mathrm{K}+ \\
\text { ATPase }\end{array}$ & SARP & & $\begin{array}{c}\text { UBE3- } \\
\text { Lig }\end{array}$ \\
\hline
\end{tabular}

B)

\section{$\underline{\text { Secondary Confirmations }}$}

Genes decreased in Cataract vs. Normal lenses

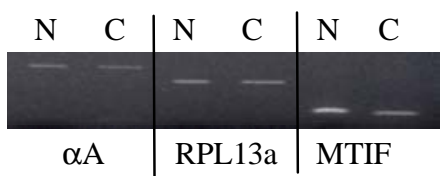

Genes increased in Cataract vs. Normal lenses

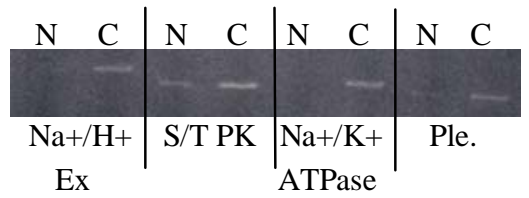


Figure 4. RT-PCR confirmation of gene expression differences for A. HSP27-1 and -2 and B. 3 control genes whose expression levels should be equal between cataract (C) and clear $(\mathrm{N})$ lens epithelia. The total amount of RNA (ng) used in each reaction is indicated. 
A.

\begin{tabular}{rrrrrr}
\multicolumn{7}{c}{ Hsp27-1 } \\
$\mathrm{C}$ & $\mathrm{N}$ & $\mathrm{N}$ & $\mathrm{N}$ & $\mathrm{N}$ & $\mathrm{N}$ \\
$\mathbf{5 0}$ & 5 & 10 & 30 & $\mathbf{5 0}$ & 100 \\
& & & - & - & $\mathbf{0}$
\end{tabular}

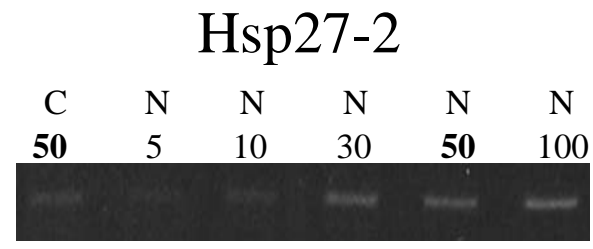

B.

\begin{tabular}{cccccc}
\multicolumn{6}{c}{$\alpha \mathrm{B}-$ Crystallin } \\
$\mathrm{C}$ & $\mathrm{N}$ & $\mathrm{N}$ & $\mathrm{N}$ & $\mathrm{N}$ & $\mathrm{N}$ \\
$\mathbf{5 0}$ & 5 & 10 & 30 & $\mathbf{5 0}$ & 100 \\
\hline & - & - & - & - & -
\end{tabular}

Catalase

\begin{tabular}{cccccc}
$\mathrm{C}$ & $\mathrm{N}$ & $\mathrm{N}$ & $\mathrm{N}$ & $\mathrm{N}$ & $\mathrm{N}$ \\
$\mathbf{5 0}$ & 5 & 10 & 30 & $\mathbf{5 0}$ & 100 \\
\hline & & & & &
\end{tabular}

MTF-1

\begin{tabular}{cccccc}
$\mathrm{C}$ & $\mathrm{N}$ & $\mathrm{N}$ & $\mathrm{N}$ & $\mathrm{N}$ & $\mathrm{N}$ \\
$\mathbf{5 0}$ & 5 & 10 & 30 & $\mathbf{5 0}$ & 100 \\
\hline & & & & &
\end{tabular}


Figure 5. Functional cluster analysis of genes involved in biological processes which have increased expression levels in cataract vs. clear lenses. Functional cluster analysis of genes involved in biological processes which have increased expression levels in cataract compared to clear lenses. The specific sub-categories of genes determined to be significantly altered using the statistical clustering program, EASE, are indicated. Percentages indicate the number of altered genes in each sub-category relative to their total representation on the microarray. Colors denote the approximate cellular location for which the genes in each sub-category function ranging from the nucleus to the plasma membrane (red to violet). Individual genes in each category are listed in Table 4. Pie piece size approximates the number of changed genes in each sub-category. 


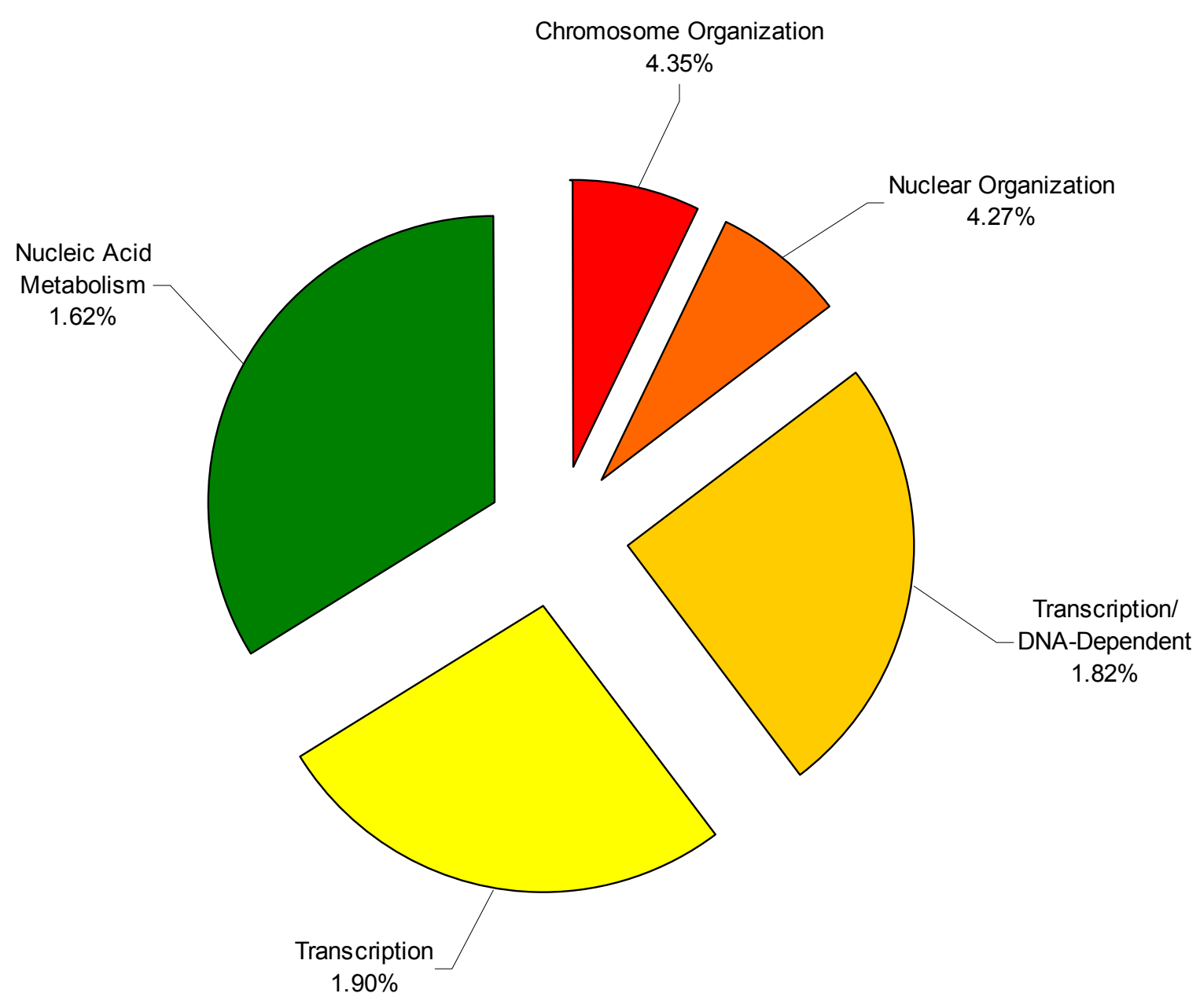


Figure 6. Functional cluster analysis of genes involved in molecular functions which have increased expression levels in cataract vs. clear lenses. Functional cluster analysis of genes involved in molecular functions which have increased expression levels in cataract compared to clear lenses. The specific sub-categories of genes determined to be significantly altered using the statistical clustering program, EASE, are indicated. Percentages indicate the number of altered genes in each sub-category relative to their total representation on the microarray. Colors denote the approximate cellular location for which the genes in each sub-category function ranging from the nucleus to the plasma membrane (red to violet). Individual genes in each category are listed in Table 4. Pie piece size approximates the number of changed genes in each sub-category. 

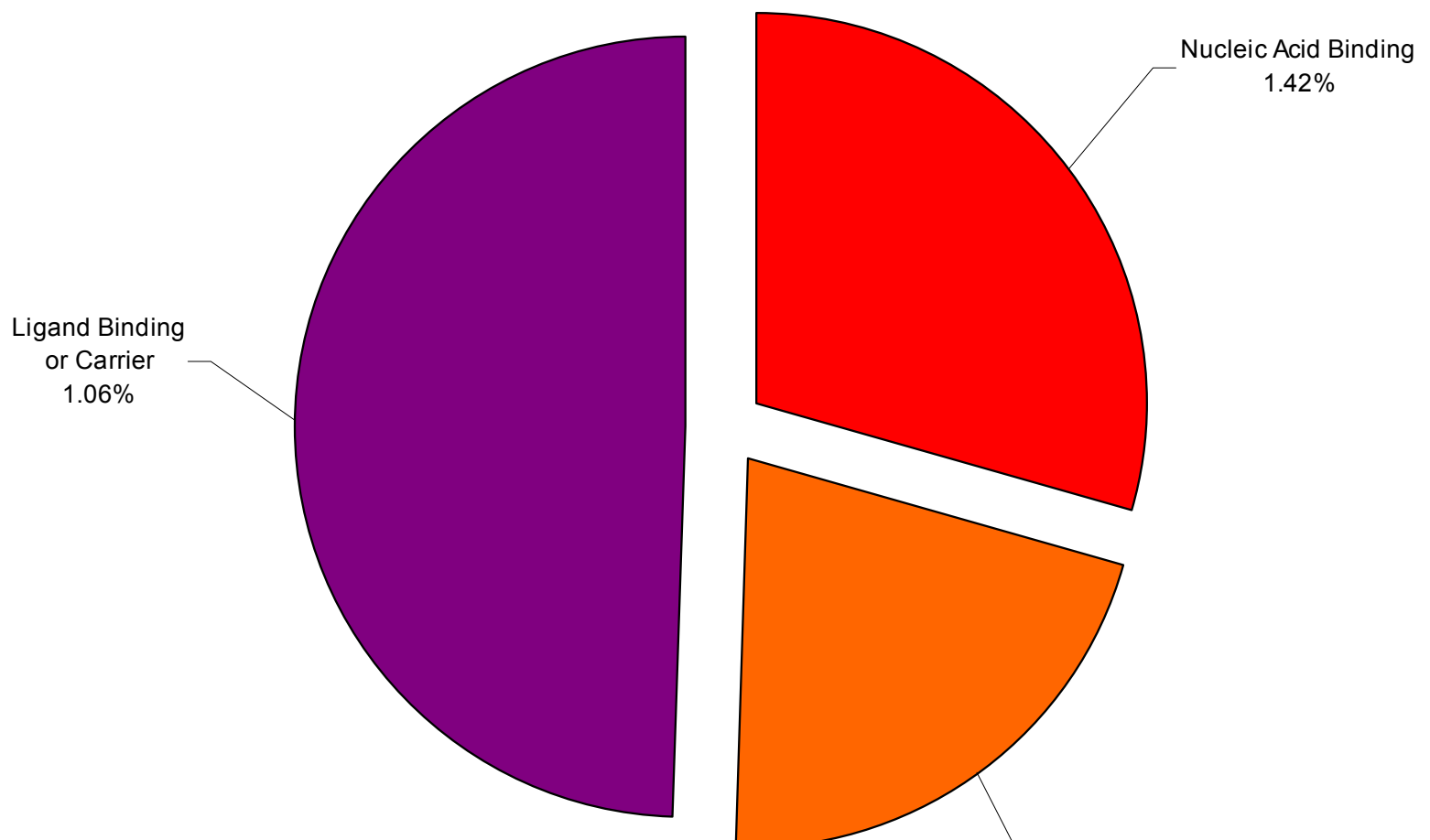
$1.42 \%$

DNA Binding

$1.38 \%$ 
Figure 7. Functional cluster analysis of genes involved in biological processes which have decreased expression levels in cataract vs. clear lenses. Functional cluster analysis of genes involved in biological processes which have decreased expression levels in cataract compared to clear lenses. The specific sub-categories of genes determined to be significantly altered using the statistical clustering program, EASE, are indicated. Percentages indicate the number of altered genes in each sub-category relative to their total representation on the microarray. Colors denote the approximate cellular location for which the genes in each sub-category function ranging from the nucleus to the plasma membrane (red to violet). Individual genes in each category are listed in Table 4. Pie piece size approximates the number of changed genes in each sub-category. 


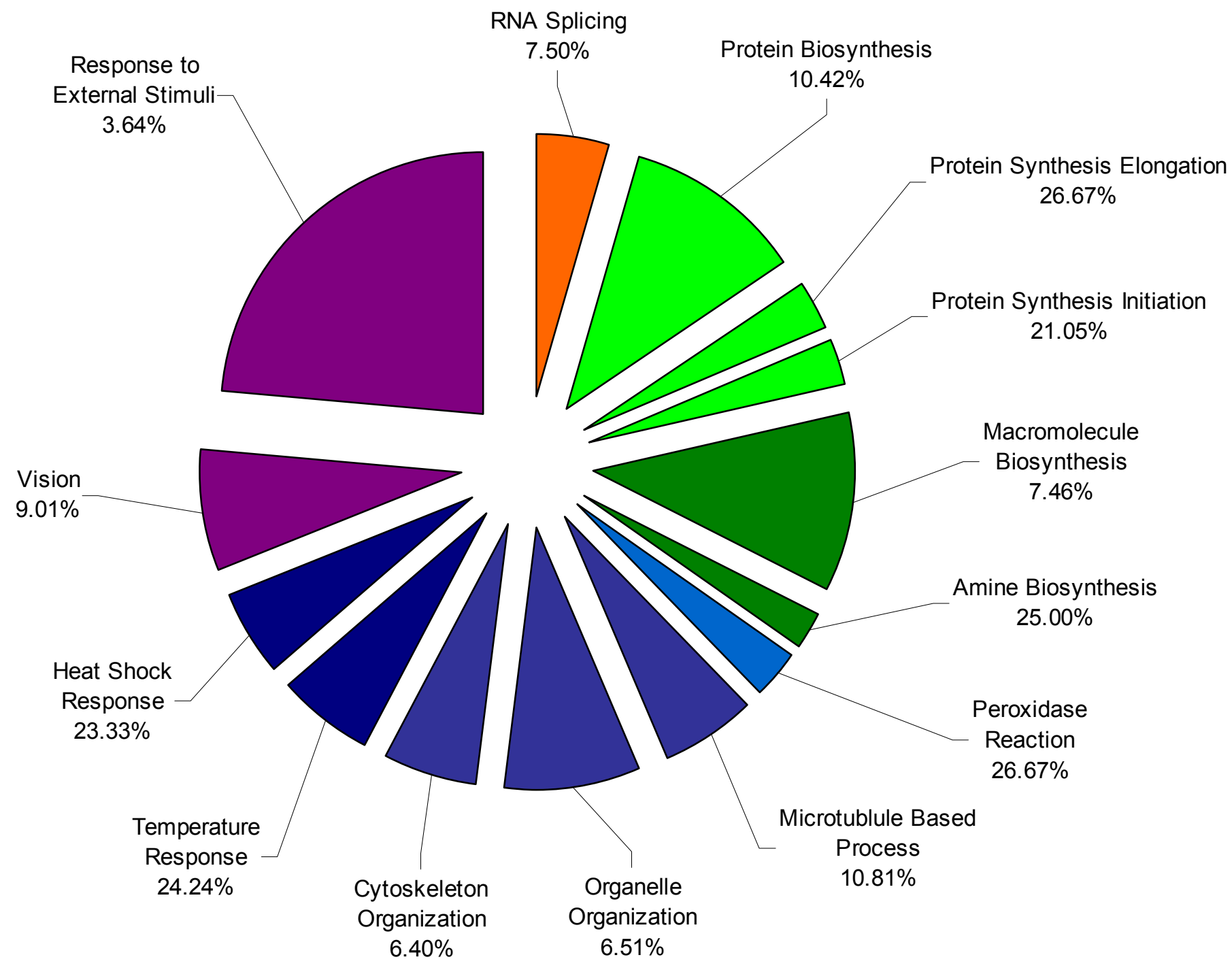


Figure 8. Functional cluster analysis of genes involved in molecular functions which have decreased expression levels in cataract vs. clear lenses. Functional cluster analysis of genes involved in molecular functions which have decreased expression levels in cataract compared to clear lenses. The specific sub-categories of genes determined to be significantly altered using the statistical clustering program, EASE, are indicated. Percentages indicate the number of altered genes in each sub-category relative to their total representation on the microarray. Colors denote the approximate cellular location for which the genes in each sub-category function ranging from the nucleus to the plasma membrane (red to violet). Individual genes in each category are listed in Table 4. Pie piece size approximates the number of changed genes in each sub-category. 


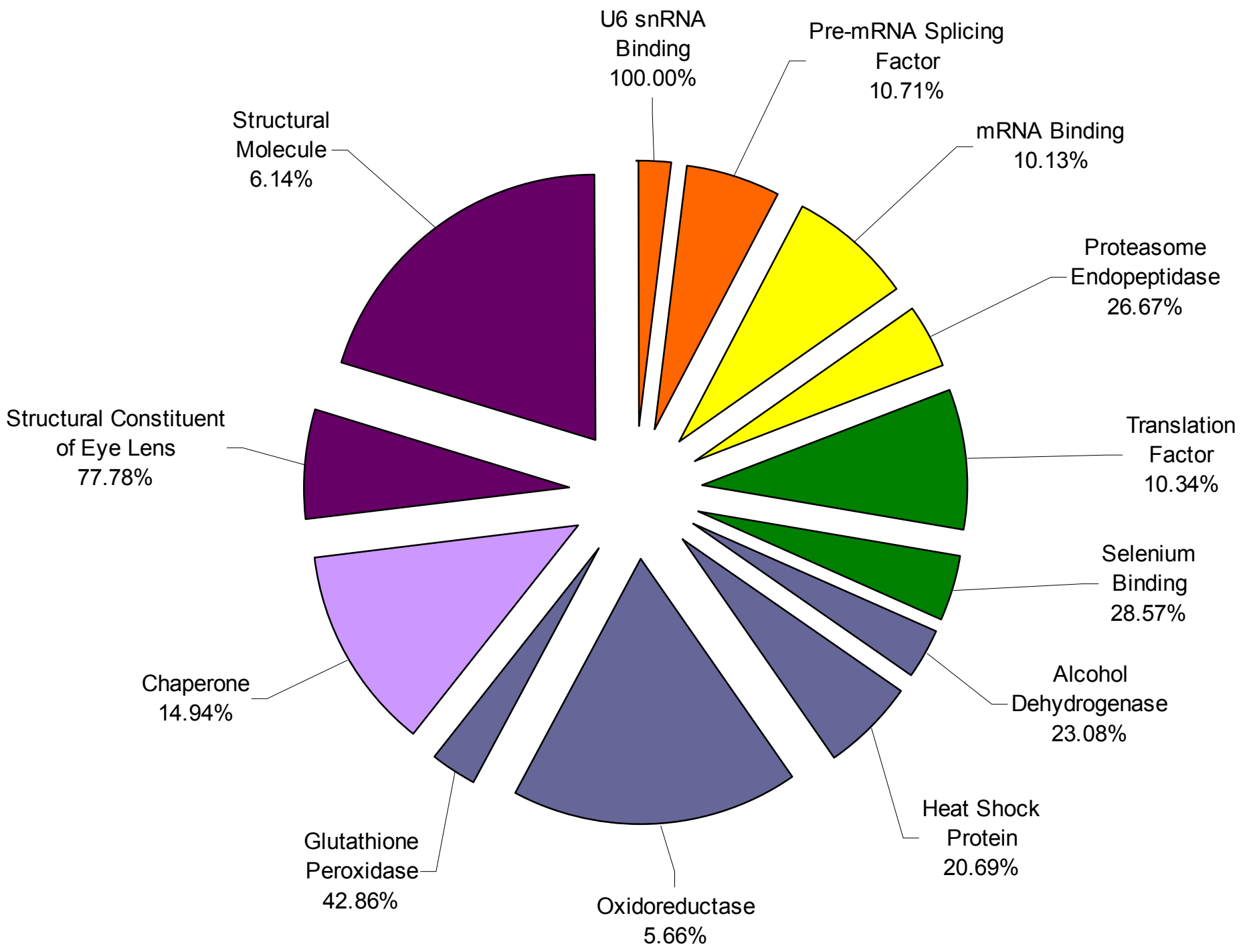




\section{DISCUSSION}

In the present study, we have compared the relative expression levels of more than half of the genes predicted to comprise the human genome between age-matched cataract and clear human lenses, confirmed the accuracy of the data set by semiquantitative RT-PCR and clustered the differentially expressed genes into functional categories. This analysis has identified over 1300 genes that are altered in cataract relative to clear lenses. Of these, 74 are increased and 241 are decreased at the 5 -fold or greater level between cataract and clear lenses. Although limitations in obtaining sufficient numbers of cataract and clear lenses preclude the extensive analysis of individual genes at the mRNA and protein levels, we estimate that the trends in gene expression detected in the microarray procedure are approximately $84 \%$ accurate based on semi-quantitative RT-PCR using separately isolated RNA populations. Although we cannot rule out the possibility that temporal and/or spatial differences between cataract and clear lenses may influence the results of the present study, we are confident that the differences in gene expression detected are truly cataract-specific since the lenses were approximately age-matched (cataract approximately 70.2 years and clear lenses approximately 61.5 years), controlled for the proportion of males and females between the two samples (approximately 45\% male), used within 24 hours post-mortem and carefully dissected for central epithelium $(2-3 \mathrm{~mm}$ cataract and $6-8 \mathrm{~mm}$ clear $)$. The cataracts examined in this study were mostly mixed and nuclear (70\% mixed, 20\% nuclear, $5 \%$ cortical and $2 \%$ posterior sub-capsular) therefore, the effects in gene expression detected in the present survey most likely reflect general gene expression changes associated with age-related cataract and are unlikely to be related to specific types of cataracts except for possibly nuclear. Large numbers of specific types of 
cataracts will need to be collected in order to analyze type-specific gene expression patterns. However, it is important to note that many of the same genes and their corresponding magnitude changes detected in the present study correlate almost exactly with the gene expression differences and magnitude changes detected between cataract epithelia and clear lens epithelia using an entirely different population of human subjects as well as a different type of hybridization screening (Ruotolo et al 2003). This complementary study provides great confidence in the gene expression differences detected in the present survey.

The present study provides evidence for multiple novel differences in gene expression between cataract and clear human lenses. Although descriptions of all of the individual genes that exhibit altered expression are too cumbersome to report, and many of the detected gene expression differences involve ESTs with no known function, some observations can be made. The majority of genes whose expression levels are altered in cataract exhibit decreased expression. These genes function in diverse processes including protein synthesis, oxidative stress, membrane transport, structural proteins, chaperones and cell cycle control proteins. Many of these processes represent metabolic systems designed to preserve lens homeostasis and their decreased expression may reflect the inability of the lens to maintain its internal environment in the presence of stress. Specific examples of individual genes that exhibit decreased expression in cataract include: multiple ribosomal subunits involved in protein synthesis including large subunits $21,15,13$ a and 7 a previously shown to be decreased in cataract relative to clear human lenses (Zhang, Hawse, Huang, Sheets, Miller, Horwitz, and Kantorow 2002); selenoprotein $\mathrm{W} 1$, a glutathione dependant antioxidant known to protect lung cells against $\mathrm{H}_{2} \mathrm{O}_{2}$ cytotoxicity (Jeong et al 2002) that could play a role in defending the lens 
against oxidative damage; $\mathrm{Na} / \mathrm{K}$ ATPase, a membrane transporter likely to be critical for osmotic regulation of the lens, whose proteins levels have previously been shown to be decreased in lens epithelia isolated from human age-related cataract (Tseng and Tang 1999); glutathione peroxidases 1,3 and 4, important oxidative stress enzymes that are likely to play major roles in lens protection and maintenance (Reddy et al 2001); ferritin, which has been linked to hereditary hyperferritinemia-cataract syndrome (Martin et al 1998); multiple crystallins and other lens structural components; Hsp70, a key ATPase activated chaperone (Haslbeck 2002); Hsp27-1, a small heat-shock protein likely to be important for lens protection (Ganea 2001); Hsp27-2, a small heat shock protein closely related to alphaB-crystallin (Iwaki et al 1997) which may also be important for lens protection and alphaA-crystallin that, in addition to its structural role in the lens, is also a small heat shock protein that can prevent protein aggregation in the lens (Horwitz 1992).

The microarray data showing 21 large and small ribosomal subunit transcripts that have decreased expression levels of 2-fold or greater in cataracts is consistent with differential display results showing that 4 of the large ribosomal subunit transcripts are decreased in cataractous lenses (Zhang, Hawse, Huang, Sheets, Miller, Horwitz, and Kantorow 2002). This process reflects a generalized decrease in protein synthesis in cataractous lens epithelial cells.

We also found significant decreases in genes associated with oxidative stress such as glutathione peroxidase, the metallothionein I genes, quinone oxidoreductase and transketolase. It has previously been demonstrated that glutathione peroxidase-1deficient mice develop cataracts at an early age (Reddy, Giblin, Lin, Dang, Unakar, Musch, Boyle, Takemoto, Ho, Knoernschild, Juenemann, and Lutjen-Drecoll 2001) and that the levels of glutathione peroxidase are significantly decreased in the plasma of 
patients with senile cataracts (Xue et al 1996). It is also known that oxidative stress occurs when the quinone oxidoreductase gene is damaged resulting in the production of oxygen radicals (Pitkanen and Robinson 1996). The down regulation of the quinone oxidoreductase gene would also result in the same outcome, an increase in the overall production of oxygen radicals. Others have shown that the loss of transketolase function, an enzyme that catalyzes two of three reactions for entry into the pentose-phosphate pathway, a major source of chemical reducing power, results in lens fiber cell degeneration (Frederikse et al 1999).

Another major functional category exhibiting decreased gene expression in cataracts is the small heat shock proteins/chaperones. Small heat shock proteins (sHSPs) are a large family of proteins that, unlike the large HSPs which are mainly involved in protein folding, play an important role in protecting organisms against stress (Ganea 2001). This study specifically found rather large decreases in many of the crystallin proteins as well as HSP27. Mice lacking the $\alpha$ A-crystallin gene develop cataracts at an early age (Brady et al 1997b) and a mis-sense mutation in the gene has been genetically linked to one form of autosomal dominant congenital cataracts in mice (Cobb and Petrash 2000) and humans (Litt et al 1998; Pras et al 2000).

Many of the genes encoding structural lens proteins also exhibited decreased expression in cataract. This includes many of the $\beta$ - and $\gamma$-crystallins which are thought to be essential for lens clarity and refraction. Indeed, mutations in $\beta$-crystallins have also been related to cataract formation, including a nonsense mutation in $\beta \mathrm{B} 1$-crystallin (Mackay et al 2002) and a mutation in the $\beta$ B2-crystallin gene (Graw et al 2001). Two other genes involved in lens structure are filensin and phakinin. These two genes together make up the lens-specific intermediate filament known as the Beaded Filament 
(Gounari et al 1997). It has been shown that the filensin protein is absent in lenses that have posterior sub-capsular cataracts (Hess et al 1998).

One additional functional category exhibiting decreased expression in cataractous lenses is the cyclins. This includes cyclin D1, cyclin G1 and BCL-1. Although there are very few reports examining the effects of these gene in the lens or their effects, if any, on cataract formation, one group of researchers has demonstrated that overexpression of cyclin G1 in fetal human lens epithelial cells results in an increased incidence of apoptosis (Kampmeier et al 2000).

Fewer genes exhibited increased expression in cataract. These genes function in processes as diverse as transcriptional control, ion transport, cytoplasmic transport, ion regulation, $\mathrm{Ca}^{2+}$ homeostasis, protein salvaging pathways and extracellular matrix interactions. Many of the pathways that exhibit increased expression in cataract are also associated with transcriptional processes that may represent attempts by the lens to compensate for stresses related to cataract. Specific examples of individual genes include: multiple zinc finger proteins, important for transcriptional regulation, $\mathrm{Na} / \mathrm{H}$ exchangers, which play key roles in regulating intracellular $\mathrm{pH}$ levels (Sangan et al 2002); multiple calcium transporters and chloride channels, important for the maintenance of cellular homeostasis; osteonectin, a calcium-binding protein that functions in the regulation of cell growth (Sage et al 1995) and adducin, a member of a gene family encoding cytoskeletal proteins (Gilligan et al 2002).

According to the EASE analysis, functionally related groups of genes that exhibit overall trends of increased expression in cataracts include peptidyl-prolyl cis-trans isomerases. Twenty five percent of cyclophilin-like peptidyl-prolyl cis-trans isomerases present on the microarray exhibited increased gene expression in cataract including RAN 
binding protein. The peptidyl-prolyl cis-trans isomerases catalyze the cis-trans isomerization of prolyl-peptide bonds (Rassow and Pfanner 1996; Rudd et al 1995; Schmid 1993). Some peptidyl-prolyl cis-trans isomerases may also possess chaperone activity by binding to and inhibiting the formation of misfolded protein aggregates (Freskgard et al 1992; Lilie et al 1993; Rinfret et al 1994). It is possible that these isomerases are increased in cataracts in an attempt to prevent the aggregation of proteins in the lens which occur during cataract formation. Splice variants of a new class of cyclophilin-related proteins, types I and II, have been isolated (Ferreira PA 1995; Ferreira et al 1995) and it was found that the type II isoform is identical to Ran-binding protein 2 (RanBP2) (Wu et al 1995; Yokoyama et al 1995).

Ran-binding protein 2 is a component of the nuclear pore complex which mediates macromolecular transport between the nucleus and the cytoplasm of the cell and serves the cell's requirement for bi-directional, selective, diverse and high-volume transport between these two compartments (Walther et al 2002). Thirty to 40 different proteins, called nucleoporins, have been identified as components of the nuclear pore complex (Rout and Aitchison 2000). RanBP2, which exhibited increased expression in cataracts, is the largest nucleoporin and has been localized to the cytoplasmic filaments of the nuclear pore complex (Wilken et al 1995). RanBP1, another cytosolic protein closely related to RanBP2, is also involved in nuclear transport (Gorlich and Kutay 1999) and exhibits increased expression in cataracts.

In addition to cytoplasmic transport, many genes associated with ionic transport also exhibit increased expression in cataracts. One gene in particular, cullin 5, which shares $96 \%$ homology with vasopressin-activated $\mathrm{Ca}^{2+}$-mobilizing receptor, is increased in cataract. Although its specific function is currently unknown, it is likely to be 
involved in the $\mathrm{Ca}^{2+}$ and cAMP dependent cell signaling pathways (Burnatowska-Hledin et al 2000). Organ culture studies of the bovine lens demonstrate that a marked decrease in protein synthesis and a net leakage of proteins is strongly associated with an increase in calcium concentration (Duncan and Jacob 1984). The activity of $\mathrm{Ca}^{2+}$-ATPase has also been shown to be reduced by $50 \%$ in the membranes of lens epithelia isolated from cataractous lenses compared to clear human lenses (Paterson et al 1997). Oxidative stress has also been demonstrated to have an effect on the activity of $\mathrm{Ca}^{2+}$ transporters in the lens. For example, hydrogen peroxide decreases the activity of $\mathrm{Ca}^{2+}$ transporters in rabbit lenses (Borchman et al 1989). These phenomenon's are closely associated with our results demonstrating an increase in $\mathrm{Ca}^{2+}$ transporters, possibly in an attempt to overcome their decreased activity in cataractous lenses, as well as a decrease in genes associated with protein synthesis.

Another ion channel that demonstrated increased expression in cataracts is the $\mathrm{Na}^{+} / \mathrm{H}^{+}$exchanger isoform 2. Electroneutral $\mathrm{Na}^{+}-\mathrm{H}^{+}$exchange is present in virtually all cell types and mediates the exchange of extracellular $\mathrm{Na}^{+}$for intracellular $\mathrm{H}^{+}$and therefore plays an important role in regulating the intracellular $\mathrm{pH}$ level, cell volume and transepithelial $\mathrm{Na}^{+}$absorption (Sangan, Rajendran, Geibel, and Binder 2002). Intracellular $\mathrm{pH}$ can affect many cell functions such as metabolic activity, protein synthesis and cell growth rates (Bonanno 1991). Previous studies have demonstrated that the $\mathrm{Na}^{+} / \mathrm{H}^{+}$exchangers play a significant role in regulating the intracellular $\mathrm{pH}$ of cultured bovine lens epithelial cells (Williams et al 1992). It is also known that the type I $\mathrm{Na}^{+} / \mathrm{H}^{+}$exchanger is activated by hypertonicity in many cell types (Garnovskaya et al 2003) and the epithelial cells of toad lenses exposed to hypertonic conditions become 
acidified stimulating the $\mathrm{Na}^{+} / \mathrm{H}^{+}$exchanger to return the $\mathrm{pH}$ of the epithelial cells back to normal levels (Wolosin et al 1989).

Another major group of genes that exhibit increased expression in cataractous epithelia compared to normal clear epithelia encode extracellular matrix proteins. Specifically, adducin, a family member of genes encoding cytoskeletal proteins (Gilligan, Sarid, and Weese 2002) was increased in cataract. A second gene, pleiotrophin, which is also an extracellular matrix protein that binds heparin (Fath et al 1999) and is induced during wound repair (Deuel et al 2002), is also increased in cataracts. Claudin, a component of tight junction filaments capable of interacting adhesively with complementary molecules on adjacent epithelial cells (Gonzalez-Mariscal et al 2003), also exhibits increased expression in cataracts. Recent studies have found that overexpression of claudin-2 induces cation-selective channels in tight junctions of epithelial cells resulting in increased ion permeability (Amasheh et al 2002). Another extracellular matrix gene whose expression is increased in cataracts is supervillin, an Factin bundling plasma membrane protein that contains functional nuclear localization signals (Wulfkuhle et al 1999). Bamacan, a chondroitin sulfate proteoglycan that abounds in basement membranes and is thought to be involved in the control of cell growth and transformation (Ghiselli et al 1999), also exhibits increased expression in cataracts. One final extracellular matrix gene that is increased in cataracts is Osteonectin which has previously been demonstrated to be increased in human age-related cataracts (Kantorow, Horwitz, and Carper 1998a).

In summary, this report identifies the global gene expression changes associated with age-related cataract and provides evidence for specific biological pathways that are associated with this disease. It is not possible from this study to determine whether these 
gene expression differences are a cause of cataract formation or a response of the lens to the presence of the cataract. However, future confirmation at the protein level and functional analysis of the identified genes in tissue culture and animal model systems will eventually help define the individual roles that the identified genes play in lens maintenance, protection and cataract. Analysis of the identified pathways will yield important information concerning the regulation of gene expression in age-related cataract and may aid in the development of therapeutic treatments to prevent or delay the onset of this disease. 


\section{Chapter V}

Identification and Functional Gene Clustering of Global Gene Expression Differences between Age-Related Cataract and Clear Human Lenses and Aging Clear Human Lenses

J. R. Hawse, J. F. Hejtmancik, J. Horwitz, M. Kantorow 


\section{ABSTRACT}

Purpose: To identify global gene expression differences between lens epithelia isolated from age-related cataract and clear lenses and aging clear lenses.

Methods: Gene expression profiles were examined by oligonucleotide microarray hybridization using chips containing over 22,000 genes. Differentially expressed transcripts were clustered according to their known functions. Gene expression changes were confirmed by RT-PCR using multiple separately isolated RNA populations.

Results: 412 transcripts were increased and 919 transcripts were decreased at the 2-fold or greater level between epithelia isolated from cataract verses clear lenses. Of the genes increased in cataract, the majority have functions involving transcription regulation, nucleic acid binding, protein processing, ion transport and cell growth. Of the gene decreased in cataract the majority have functions involving heat-shock/chaperone activity, protein synthesis/degradation, oxidative stress and metal binding. 182 transcripts were increased and 547 transcripts were decreased in old lenses relative to young lenses at the 2-fold or greater level. In comparing the cataract gene expression changes with the aging gene expression changes, only 3 transcripts share similarities in expression trends between the two sets of data.

Conclusions: The data provide evidence for multiple gene expression differences between lens epithelia isolated from cataract and clear lenses and point to multiple pathways likely to be important for age-related cataract. The data also indicate that the majority of gene expression changes detected in cataracts are likely to be cataract-specific and not due to aging of the lens. 


\section{INTRODUCTION}

Age-related cataract is a multi-factorial disease contributed by aging, genetics and environmental factors that among others include UV-light, X-irradiation, toxins, metal exposure, steroids, drugs and diseases including diabetes (Phelps Brown 1996). These combined factors result in numerous lens changes that culminate to produce lens opacity including increased proteolysis, alterations in the cell cycle, altered growth and differentiation of lens epithelial cells, altered ion transport and osmotic balance as well as DNA damage (Phelps Brown 1996).

An important step in understanding cataractogenesis is to identify those metabolic and biochemical pathways altered between cataract and clear lenses. In the present survey we have sought to identify those gene expression differences between clear human lenses relative to age-related cataracts and we have focused on the lens epithelium since this monolayer of cells is essential for the growth, differentiation and homeostasis of the entire organ (Bloemendal 1981; Piatigorsky 1981a). It contains the highest levels of enzymes and transport systems in the lens (Reddan JR. 1982; Reddy 1971b; Spector 1982a) and is the first part of the lens exposed to environmental insults (Reddan JR. 1982; Spector 1982a). Multiple studies suggest that the lens epithelium is capable of communicating with the underlying fiber cells (Rae, Bartling, Rae, and Mathias 1996b) and direct damage to the lens epithelium and its enzyme systems is known to result in cataract formation (Harding JJ 1984; Hightower 1995; Phelps Brown 1996; Spector 1995). Importantly, the majority of transcription occurs in the epithelial cells of the lens, and therefore these cells make up the majority of lens cells capable of responding to environmental insults and/or the presence of cataract through altered gene expression. 
Since the lens epithelium is composed of a single cell-type it represents an ideal model for differential gene expression studies.

Considerable evidence suggests that gene expression in the lens epithelium is altered by the presence of cataract. For instance, metallothionein IIa (Kantorow, Kays, Horwitz, Huang, Sun, Piatigorsky, and Carper 1998b) osteonectin, also known as SPARC (Kantorow, Horwitz, and Carper 1998a) and adhesion related kinase (Sheets et al 2002) are up-regulated in cataract relative to clear lenses while multiple ribosomal proteins (Zhang, Hawse, Huang, Sheets, Miller, Horwitz, and Kantorow 2002) and protein phosphatase 2A (Kantorow, Kays, Horwitz, Huang, Sun, Piatigorsky, and Carper 1998b) are down-regulated in cataract relative to clear lenses. Many of these genes have functions consistent with processes associated with cataract formation. Metallothionein IIa is involved in metal binding and detoxification (Kagi and Schaffer 1988) and heavy metals such as cadmium are known to be associated with cataract (Ramakrishnan, Sulochana, Selvaraj, Abdul, Lakshmi, and Arunagiri 1995). Osteonectin, a calciumbinding protein that functions in the regulation of cell growth (Sage, Bassuk, Yost, Folkman, and Lane 1995), when deleted in mice results in cataract formation (Gilmour et al 1998). Decreased expression of ribosomal proteins results in decreased protein synthesis, a phenomenon that has been linked to cataract formation (Haloui, Pujol, Galera, Courtois, and Laurent 1990).

Although these individual changes in gene expression are informative, further gene identification is needed to define those functional gene clusters that could elucidate major pathways associated with cataract. Here, we have used oligonucleotide microarrays to compare the global gene expression profiles between pooled, approximately age-matched, human lens epithelia isolated from cataract and clear lenses 
and have compared the data set with those genes altered in aging of the lens epithelium to delineate cataract specific changes from age-related changes in gene expression. This technology allows us to examine the expression levels of well over half of the genes comprising the human genome. 


\section{RESULTS}

This analysis revealed 412 transcripts whose expression levels are increased by 2fold or greater in human age-related cataract relative to clear lenses and an additional 919 transcripts whose expression levels are decreased by 2-fold or greater (Hawse et al 2003). Of these genes, 74 are increased by 5 -fold or greater and 241 are decreased by 5 -fold or greater in cataract (Hawse, Hejtmancik, Huang, Sheets, Hosack, Lempicki, Horwitz, and Kantorow 2003). Semi-quantitative RT-PCR confirmations indicate that the microarray data is approximately $82 \%$ accurate (Hawse, Hejtmancik, Huang, Sheets, Hosack, Lempicki, Horwitz, and Kantorow 2003).

Functional clustering and over-representation analysis of the identified genes using the EASE bioinformatics software package revealed that multiple biological pathways represented by functional gene clusters are significantly altered upon cataract formation. Of the genes increased in cataract by 2-fold or greater the following categories were identified as being significantly altered; chromosome organization, nuclear organization, transcription/DNA-dependent, transcription, nucleic acid metabolism, nucleic acid binding, ligand binding or carrier and DNA binding (Hawse, Hejtmancik, Huang, Sheets, Hosack, Lempicki, Horwitz, and Kantorow 2003). Of the genes decreased in cataract by 2 -fold or greater the following categories were identified as being significantly altered; RNA splicing, protein biosynthesis, protein synthesis elongation, protein synthesis initiation, macromolecule biosynthesis, amine biosynthesis, peroxidase reaction, microtubule-based process, organelle organization, cytoskeleton organization, temperature response, heat shock response, vision, response to external stimulus, U6 snRNA binding, pre-mRNA splicing factor, mRNA binding, proteasome 
endopeptidase, translation factor, selenium binding, alcohol dehydrogenase, heat shock protein, oxidoreductase, glutathione peroxidase, chaperone, structural constituents of lens and structural molecules (Hawse, Hejtmancik, Huang, Sheets, Hosack, Lempicki, Horwitz, and Kantorow 2003).

One intriguing question concerning these gene expression changes is whether they would be specific for cataract or would also be detected in young verses old lenses. Therefore, we have also conducted oligonucleotide microarray studies on old and young lens epithelia to identify gene expression changes that occur in the lens with age. For this experiment we used 10 pooled young lens epithelia, average age 32.3 years, and 10 pooled old lens epithelia, average age 64.2 years. This analysis revealed that 182 transcripts are increased in old lenses compared to young lenses while 547 transcripts are decreased at the 2-fold or greater level. Of these, only 4 transcripts are increased with age at the 5-fold or greater level while 74 transcripts are decreased with age at the 5-fold or greater level.

Functional clustering of the identified gene expression differences between young and old lenses revealed that Biological Processes such as regulation of translation, protein synthesis, intracellular transport, cell growth and/or maintenance, and response to stress, among others, are increased with age (Figure 1) while Biological Processes such as double-strand break repair, telomere maintenance, transcription, chromosome segregation, extracellular matrix organization and DNA unwinding, among others, are decreased with age (Figure 2). 
Figure 1. Functional clusters of genes involved in biological processes which have increased expression levels in old lens epithelium compared to young lens epithelium. The specific sub-categories of genes determined to be significantly altered using the statistical clustering program, EASE, are indicated. Percentages indicate the number of altered genes in each sub-category relative to their total representation on the microarray. Colors denote the approximate relative cellular location for which the genes in each subcategory function ranging from the nucleus to the plasma membrane (red to violet). Pie piece size approximates the number of changed genes in each sub-category. 


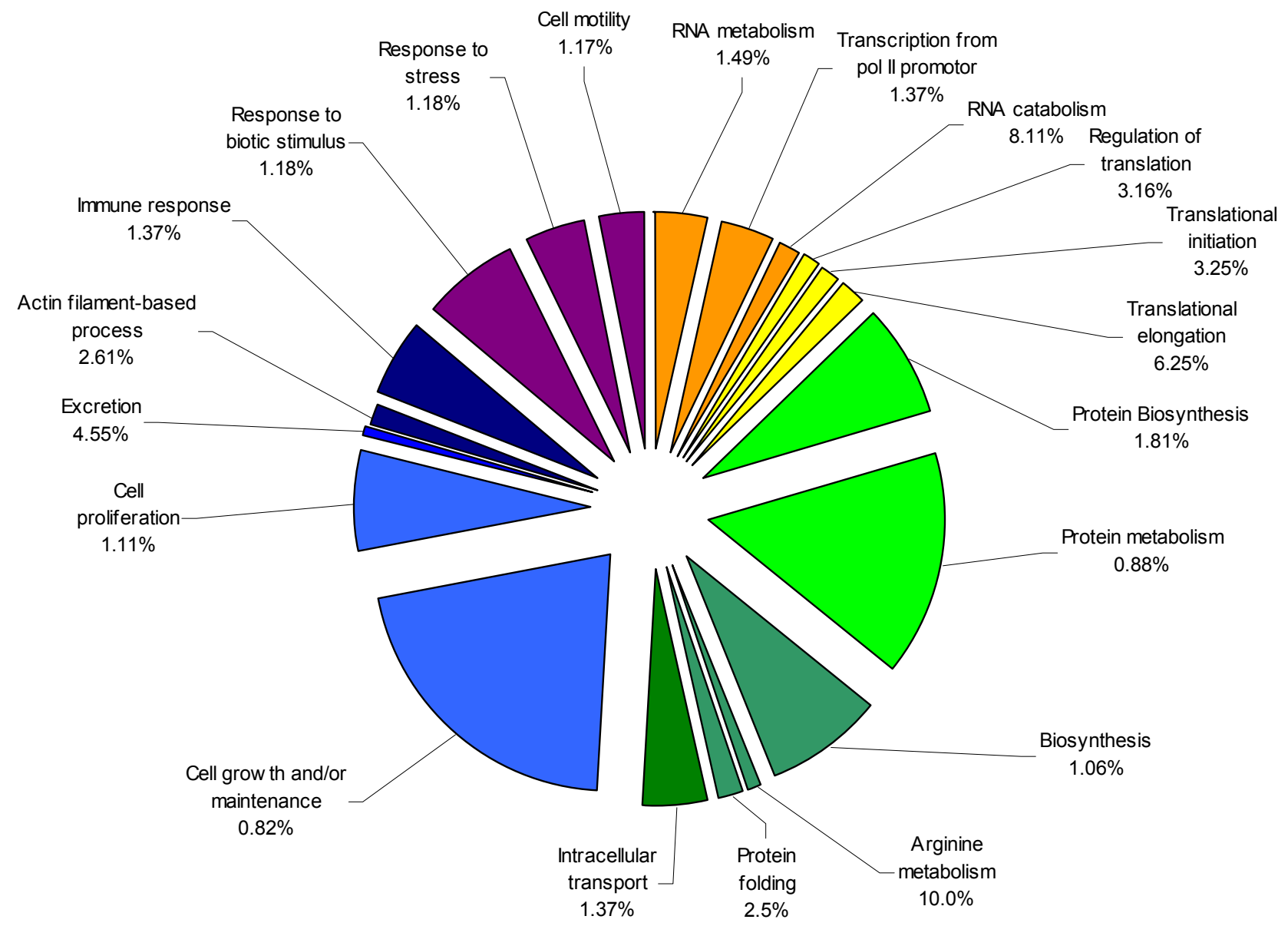


Figure 2. Functional clusters of genes involved in biological processes which have decreased expression levels in old lens epithelium compared to young lens epithelium. The specific sub-categories of genes determined to be significantly altered using the statistical clustering program, EASE, are indicated. Percentages indicate the number of altered genes in each sub-category relative to their total representation on the microarray. Colors denote the approximate relative cellular location for which the genes in each subcategory function ranging from the nucleus to the plasma membrane (red to violet). Pie piece size approximates the number of changed genes in each sub-category. 


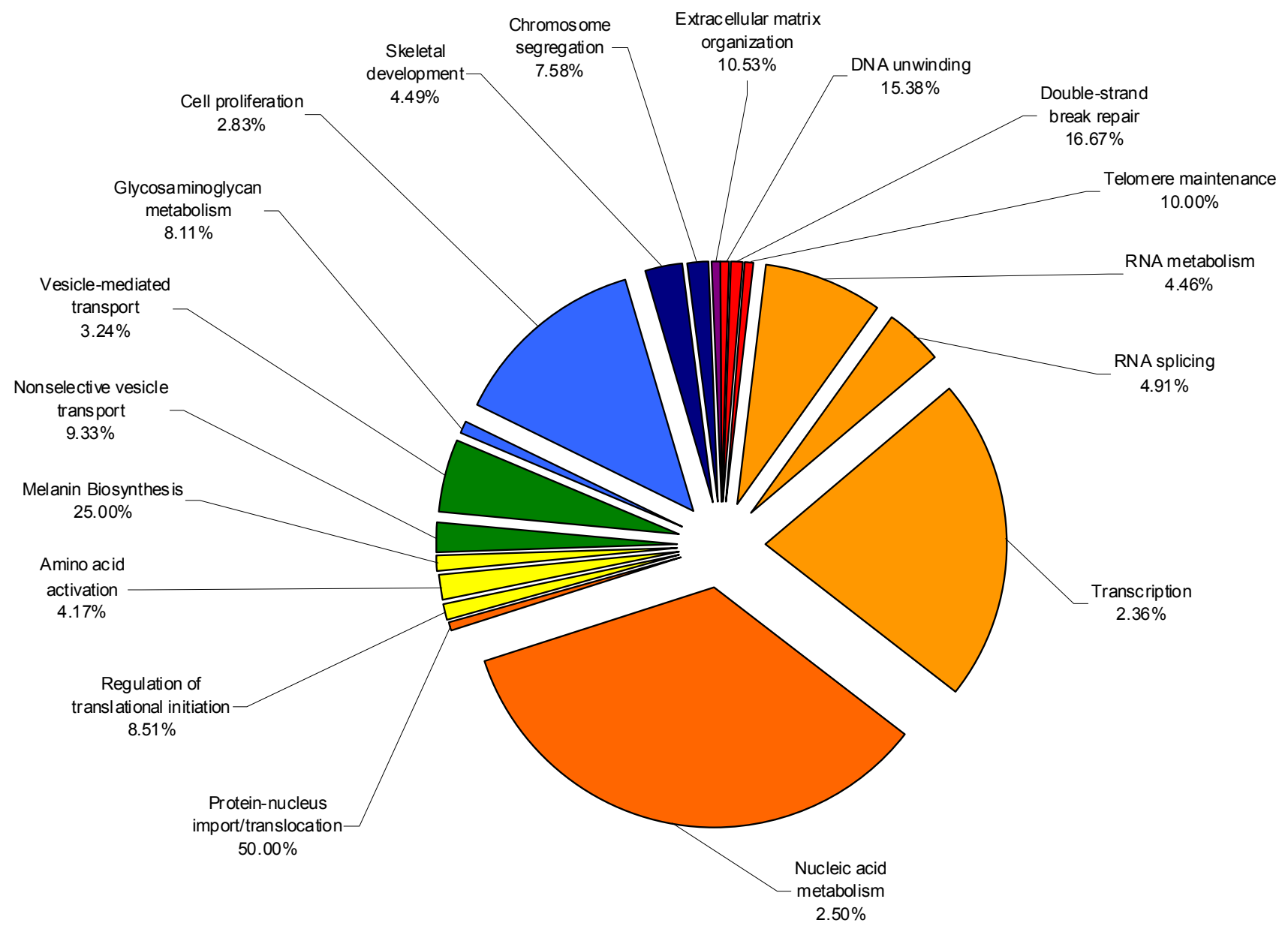




\section{DISCUSSION}

Although it is extremely difficult to summarize this large amount of data a few groups of genes that may play an important roles in cataract formation are worthy of noting. The relative expression differences of these genes and other genes not discussed here are available (Hawse, Hejtmancik, Huang, Sheets, Hosack, Lempicki, Horwitz, and Kantorow 2003). Of the genes increased in cataract, many are associated with ionic transport. In particular, a PQ type voltage gated calcium channel is increased in cataract by nearly 5-fold. Calcium is likely to be an important factor in cataract formation since the activity of calcium-ATPase is reduced by $50 \%$ in the membranes of lens epithelia isolated from cataractous lenses compared to clear human lenses (Paterson, Zeng, Husseini, Borchman, Delamere, Garland, and Jimenez-Asensio 1997). Oxidative stress has also been demonstrated to have an effect on the activity of calcium transporters in the lens. For example, hydrogen peroxide decreases the activity of calcium transporters in rabbit lenses (Borchman, Paterson, and Delamere 1989). These phenomenons are closely associated with our results demonstrating an increase in calcium transporters, possibly in an attempt to overcome their decreased activity in cataractous lenses.

Adducin, another member of the ligand binding or carrier group, is increased in cataracts by 6-fold. Adducin is a cytoskeletal protein involved in signal transduction mechanisms through modulation of the actin cytoskeleton at cell-cell contact sites (Kuhlman et al 1996). The actin based cytoskeleton has been shown to interact with epithelial sodium channels, sodium/potassium/chloride co-transporters and sodium/potassium ATPase and is therefore likely to be involved in alterations in ionic transporters. Copine III is another gene involved in membrane trafficking processes 
(Creutz et al 1998) upon calcium binding. We have detected that Copine III is increased in cataracts relative to clear lenses by 7 -fold. Other genes known to be involved in ligand binding or transport that exhibited high levels of increased expression in cataracts were sodium/potassium ATPase beta 1 polypeptide, chloride channel 3, pleiotrophin and sodium/hydrogen exchanger isoform 2.

Another major group of genes that exhibit increased expression in cataractous epithelia compared to clear lens epithelia are extracellular matrix proteins. Specific examples include adducin, pleiotrophin, an extracellular matrix protein that binds heparin (Fath, VanderNoot, Kilpelainen, Kinnunen, Rauvala, and Linhardt 1999) and is induced during wound repair (Deuel, Zhang, Yeh, Silos-Santiago, and Wang 2002). Another gene included in this category is claudin, a component of tight junction filaments capable of interacting adhesively with complementary molecules on adjacent epithelial cells (Gonzalez-Mariscal, Betanzos, Nava, and Jaramillo 2003). Recent studies have found that overexpression of claudin-2 induces cation-selective channels in tight junctions of epithelial cells resulting in increased ion permeability (Amasheh, Meiri, Gitter, Schoneberg, Mankertz, Schulzke, and Fromm 2002). Other genes include supervillin, an F-actin bundling plasma membrane protein that contains functional nuclear localization signals (Wulfkuhle, Donina, Stark, Pope, Pestonjamasp, Niswonger, and Luna 1999), bamacan, a chondroitin sulfate proteoglycan that abounds in basement membranes and is thought to be involved in the control of cell growth and transformation (Ghiselli, Siracusa, and Iozzo 1999) and osteonectin which has previously been demonstrated to be increased in human age-related cataracts (Kantorow et al 2000).

The majority of genes whose expression levels are altered between cataracts and clear lenses exhibit decreased expression. These genes function in diverse processes 
including protein synthesis, oxidative stress, structural proteins, chaperones and cell cycle control proteins. Many of these processes represent metabolic systems designed to preserve lens homeostasis and their decreased expression may reflect the inability of the lens to maintain its internal environment in the presence of stress and/or cataract. Specific examples of these genes include multiple ribosomal subunits involved in protein synthesis including large subunits $21,15,13 \mathrm{a}$ and $7 \mathrm{a}$ which were previously shown to be decreased in cataract relative to clear human lenses (Zhang, Hawse, Huang, Sheets, Miller, Horwitz, and Kantorow 2002), selenoprotein W1, a glutathione dependent antioxidant known to protect lung cells against $\mathrm{H}_{2} \mathrm{O}_{2}$ cytotoxicity (Jeong, Kim, Chung, Lee, and Kim 2002) which could play a role in defending the lens against oxidative stress, glutathione peroxidases 1, 3 and 4, important oxidative stress enzymes that are likely to play major roles in lens protection and maintenance (Reddy, Giblin, Lin, Dang, Unakar, Musch, Boyle, Takemoto, Ho, Knoernschild, Juenemann, and Lutjen-Drecoll 2001), ferritin, which has been linked to hereditary hyperferritinemia-cataract syndrome (Martin, Fargion, Brissot, Pellat, and Beaumont 1998), multiple crystallins and other lens structural components, Hsp70, a key ATPase activated chaperone (Haslbeck 2002), Hsp27-1, a small heat-shock protein likely to be important for lens protection (Ganea 2001), Hsp27-2, a small heat shock protein closely related to $\alpha \mathrm{B}$-crystallin (Iwaki, Nagano, Nakagawa, Iwaki, and Fukumaki 1997) which may also be important for lens protection, and $\alpha \mathrm{A}$-crystallin that, in addition to its structural role in the lens, is also a small heat shock protein that can prevent protein aggregation in the lens (Horwitz 1992).

Specific genes whose transcript levels were detected to be increased in old lens epithelia relative to young lens epithelia included multiple small and large ribosomal subunits as well as several translation initiation, elongation and termination factors. MIP, 
tubulin and cyclin D1 are examples of genes involved in cell growth and/or maintenance that were increased in aged lens epithelia. Another category of interest which also exhibited increased expression with age is response to stress which includes growth arrest and DNA damage-inducible alpha gene, TNF receptor member 17, beta 1 integrin and chemokine ligand 2. It must be noted that, as mentioned above, the majority of these genes have increases in transcript levels of only 2-3-fold.

There were many more genes with much larger fold changes that exhibited decreased expression with age. Major categories of these genes included double-strand break repair and telomere maintenance. Specifically we detected decreased expression levels of telomeric repeat binding factor 1, the deletion of which causes growth defects and chromosomal instability in mouse embryonic stem cells (Iwano et al 2004), dyskerin, which is believed to function in maintaining cell proliferation and/or function (Heiss et al 1999) and nijmegen breakage syndrome 1 which functions in double-strand break repair and cell cycle checkpoints (Carney et al 1998).

Another major category that exhibited decreased expression is transcription associated genes that include numerous zinc finger proteins and other transcription factors. It is well documented that many genes involved in transcriptional processes are down regulated with age in multiple tissues and organisms including rats (Blalock et al 2003), mice (Frasca et al 2003) and humans (Roy et al 2002) and their down regulation is a central hypothesis as to why cells age and eventually die.

In order to identify those gene expression differences that are likely to be specific for cataract and not aging of the lens we compared the aging data with the cataract data. In comparing these two sets of data, only 3 transcripts were identified to be common between the detected cataract specific gene expression differences and the aging specific 
gene expression differences even at the 2-fold or greater level. These three transcripts, hevin, opioid binding protein/cell adhesion molecule and FXYD domain containing ion transport regulator 6 , are decreased in cataracts compared to clear lenses and are also decreased with age. There were no genes that were increased in cataract and simultaneously increased with age. A total of 126 transcripts exhibit decreased expression in cataracts and increased expression with age while 171 transcripts are increased in cataract and decreased with age. There are 1031 transcripts identified to be changed between cataract and clear lenses but unchanged with age and another 429 transcripts that are altered with age but unchanged in cataracts. It is interesting to note that many of the functional categories that are increased in cataracts are actually decreased with age and those that are decreased in cataracts are increased with age.

In summary, this review highlights those genes and their associated functional categories that were detected to be altered in cataract relative to clear lenses.

Interestingly, our preliminary data suggest that these changes are specific for cataract and not associated with lens aging. Although this work is descriptive and does not distinguish consequential gene expression differences from true responses of the lens epithelium to the presence of cataract, it nevertheless reveals many functional processes altered in cataract whose further study will provide significant insight into this disease. 


\section{Chapter VI}

Activation of metallothioneins and alpha-crystallin/sHSPs in human lens epithelial cells by specific metals and the metal content of aging clear human lenses

John R. Hawse, Jonathan R. Cumming, Brian Oppermann, Nancy L. Sheets, Venkat N. Reddy, Marc Kantorow 


\section{ABSTRACT}

Purpose: To identify those metallothionein and $\alpha$-crystallin/small heat shock genes induced by toxic metals in human lens cells and to evaluate the levels of these metals between young and aged human lenses. Methods: Human SRA01/04 and primary human lens epithelial cells were cultured and exposed to $\mathrm{Cd}^{+2}, \mathrm{Cu}^{+2}$ and $\mathrm{Zn}^{+2}$. The levels of lens metallothioneins (Ig, If, Ih, Ie, and IIa) and $\alpha$-crystallin/small heat-shock ( $\alpha$ Acrystallin, $\alpha \mathrm{B}$-crystallin and HSP27) genes were analyzed by semi-quantitative and quantitative mimic RT-PCR. The content of aluminum, cadmium, calcium, chromium, copper, iron, lead, magnesium, manganese, nickel, potassium, sodium and zinc in young (average $32.8 \mathrm{yrs}$ ), middle-aged (average 52.3 yrs.) and old (average 70.5 yrs.) human lenses was analyzed by inductively coupled plasma emission spectroscopy. Results: Lens metallothioneins (Ig, If, Ih, Ie, and IIa) and $\alpha$-crystallin/small heat-shock genes ( $\alpha$ A-crystallin, $\alpha$ B-crystallin and HSP27) were differentially induced by specific metals in SRA01/04 human lens epithelial cells. $\mathrm{Cd}^{+2}$ and $\mathrm{Zn}^{+2}$, but not $\mathrm{Cu}^{+2}$, induced the metallothioneins while $\mathrm{Cd}^{+2}$ and $\mathrm{Cu}^{+2}$, but not $\mathrm{Zn}^{+2}$, induced $\alpha \mathrm{B}$-crystallin and HSP27. $\alpha$ A-crystallin was induced by $\mathrm{Cu}^{+2}$ only. Similar responses of the metallothionein IIa gene were detected in identically treated primary human lens epithelial cells. Cadmium and $\mathrm{Zn}^{+2}$ induced metallothionein IIa to 5-times higher levels than metallothionein Ig. Out of 13 different metals, only iron was altered, exhibiting an 81\% decrease in old versus young lenses. Conclusions: Induction of metallothioneins and $\alpha$-crystallin/small heat shock proteins by different metals indicates the presence of metal-specific lens regulatory pathways likely to be involved in protection against metal-associated stresses. 


\section{INTRODUCTION}

Toxic metals, and the genes that they induce, are associated with cell death, oxidative stress and lens cataract. Human exposures to toxic metals such as iron, copper, cadmium, lead, aluminum and others, arise from wide-spread sources including cigarette smoke, air pollution, leaching of landfills, industrial waste, emissions from fossil fuels, fertilizers and corrosion of plumbing (Artic Monitoring and Assessment Program (AMAP). 2000; Ruffett, Ayres, and McBride 1992). $\mathrm{Cd}^{+2}$ has a biological half-life in humans of up to 30 years (Grubb et al 1985) and large amounts of $\mathrm{Cd}^{+2}$ have been detected in the lenses of chronic smokers (Ramakrishnan, Sulochana, Selvaraj, Abdul, Lakshmi, and Arunagiri 1995) who also exhibit early cataract formation (Clayton et al 1984). Increased $\mathrm{Cd}^{+2}$ levels have been reported in cataract versus clear human lenses (Ramakrishnan, Sulochana, Selvaraj, Abdul, Lakshmi, and Arunagiri 1995). Iron and $\mathrm{Cu}^{+2}$ participate in Fenton- type reactions associated with oxidative stress and cataract (Phelps Brown 1996). Hyperferritinemia (Girelli, Corrocher, Bisceglia, Olivieri, De Franceschi, Zelante, and Gasparini 1995) and defects in $\mathrm{Cu}^{+2}$ transport, including Wilson's and Menkes disease (Cuthbert 1998), result in specific types of human cataract.

Biological systems have evolved numerous gene pathways to regulate and detoxify heavy metals. One major group of proteins that are believed to regulate and protect against metals is the metallothioneins (MTs). There are 16 known isoforms of MTs in humans, which are grouped into four classes: MTs I, II, III and IV. MTs are 6-7 kDa polypeptides (Kagi and Schaffer 1988) that bind a wide spectrum of metals and are rapidly induced by metals and other agents in numerous tissues (Kagi and Schaffer 1988). In addition to metals, they are induced by steroids in rat fibroblasts (Karin et al 1984) and primary human skin fibroblasts (Angel et al 1986), carcinogens in mice (Bauman et al 
1991), chemicals that induce oxidative stress in rodent cells (Fornace, Jr. et al 1988) and X-irradiation and UV-induced DNA damage in multiple cell types (Oguro and Yoshida 2001).

We have previously shown that the human lens expresses MT classes I and II including MT isoforms Ia, Ig, If, Ih, Ie and IIa (Oppermann et al 2001b). Only one isoform, MTIIa, is specific for the lens epithelium whereas the MTI isoforms are expressed at lower levels in both the lens epithelium and lens fibers (Oppermann, Zhang, Magabo, and Kantorow 2001b). In addition, MTIIa exhibits increased expression in agerelated cataract relative to clear human lenses (Kantorow, Kays, Horwitz, Huang, Sun, Piatigorsky, and Carper 1998b) suggesting a possible role for MTIIa in lens protection.

Multiple studies have demonstrated a direct role for MTs in protecting multiple cell types against a wide range of insults that are associated with metal exposure, oxidative stress and cataract. Overexpression of MT in a human trophoblastic cell line has been shown to protect against cadmium-induced apoptosis (McAleer and Tuan 2001). MT I- and II-null mice are more sensitive than wild-type mice to metal exposure and oxidative stress (Kelly et al 1996; Liu et al 1996; Masters et al 1994; Michalska and Choo 1993; Park et al 2001); however, no one has examined the lenses of these animals. Overexpression of MTIa in a human retinal pigment epithelial cell line provides direct protection against $\mathrm{Cd}^{+2}$ exposure, heme- and iron-induced oxidation and UV lightinduced apoptosis ( $\mathrm{Lu}$ et al 2002).

In addition to the MTs, the $\alpha$-crystallin/small heat shock genes have also been shown to be induced by metals in non-lens systems. Like MTs, $\alpha$ B-crystallin and HSP27 have been shown to be induced by $\mathrm{Cd}^{+2}$ in astrocytes (Head et al 1996). In addition to metals, the small heat shock proteins (sHSPs) are also induced by a wide variety of 
agents including increasing hypertonicity in retinal pigment epithelial cells (Lin et al 1993 ) and dog lens epithelial cells (Dasgupta et al 1992), vasopressin in human vascular smooth muscle cells (Kaida et al 1999), TGF- $\beta$ in human trabecular meshwork cells (Welge-Lussen et al 1999) and rat lenses (Sun et al 2000), heat shock in human and monkey trabecular meshwork (Tamm et al 1996), various rat tissues including central nervous tissue, liver, lung, spleen, adrenal glands and hypophysis (Inaguma et al 1995) and astrocytomoa cells (Inaguma et al 1992), hydrogen peroxide treatment in human and monkey trabecular meshwork cells (Tamm, Russell, Johnson, and Piatigorsky 1996) and glucocorticoids in fibroblasts (Scheier et al 1996). To date, no one has examined the levels of $\alpha$-crystallin/sHSPs induced by metals in lens cells.

Unlike MTs, whose exact functions in lens cells remain unknown, numerous studies have demonstrated a direct role for $\alpha$-crystallin/sHSPs in lens protection. Overexpression of $\alpha \mathrm{A}$ - and $\alpha \mathrm{B}$-crystallin has been shown to protect lens epithelial cells against stress-induced apoptosis (Andley et al 1998; Andley et al 2000; Andley et al 2002). $\alpha$ A-crystallin-null mice develop lens opacities at an early age (Andley, Song, Wawrousek, and Bassnett 1998; Brady et al 1997a) and the growth rate of lens epithelial cells isolated from these animals is reduced by $50 \%$ (Andley, Song, Wawrousek, and Bassnett 1998).

Based on the association between toxic metals and lens cataract, and the detection of increased MTIIa expression in age-related cataract relative to clear lenses (Kantorow, Kays, Horwitz, Huang, Sun, Piatigorsky, and Carper 1998b), we sought to further define the magnitude and specificity for induction of those lens MTs (Oppermann, Zhang, Magabo, and Kantorow 2001b) and lens $\alpha$-crystallin/sHSPs in response to 3 commonly studied metals including $\mathrm{Cd}^{+2}, \mathrm{Cu}^{+2}$ and $\mathrm{Zn}^{+2}$. To survey the metal content of aging 
human lenses, we also determined the levels of 13 different metals between young, middle-aged and old lenses.

Establishing the metal-induced expression patterns of these genes in HLEs is important, since it is essential to examine their responses in cultured lens cells before proceeding to functional and in vivo studies. Since the lens epithelium is a transcriptionally active region of the lens and is essential for the growth, differentiation, and homeostasis of the entire lens (Bloemendal 1981; Piatigorsky 1981a), and, since approximately $90 \%$ of the lens MTs are confined to this lens region (Oppermann, Zhang, Magabo, and Kantorow 2001b), the lens epithelium would be expected to be particularly responsive to toxic metals. In addition, significant levels of $\alpha$-crystallin/sHSPs that may also respond to metals (Head, Hurwitz, and Goldman 1996) are localized to this part of the lens. Since lens epithelial cells occupy the most anterior portion of the lens, and are readily exposed to environmental insults, and since these cells contain the majority of enzymes and transport systems in the lens (Reddan JR. 1982; Reddy 1971b; Spector 1982a), this region of the lens would be expected to be particularly prone to direct and/or indirect damage associated with toxic metals.

Our results provide evidence that the human lens epithelium responds to specific metals through the differential induction of 5 different MT isoforms and 3 different $\alpha$ crystallin/sHSPs, including $\alpha$ A-crystallin which, to our knowledge, has not previously been shown to be induced by metals and/or stress. Consistent with the detection of increased MTIIa expression in age-related cataract relative to clear human lenses (Kantorow, Kays, Horwitz, Huang, Sun, Piatigorsky, and Carper 1998b), MTIIa is the primary MT isoform induced in HLEs. Different MTs and $\alpha$-crystallin/sHSPs are induced by different metals suggesting specific roles for these genes in lens metal 
regulation and/or protection. With the exception of iron levels, which dramatically decrease with age, the levels of 12 different metals in healthy human lenses remain constant with age, indicating that toxic metals do not accumulate in clear human lenses. 


\section{RESULTS}

\section{Quantification of MTIIa levels relative to MTIg levels induced by $\mathrm{Cd}^{+2}, \mathrm{Cu}^{+2}$ and $\mathrm{Zn}^{+2}$ in HLEs.}

To determine the relative levels of a class II MT in comparison with a class I MT induced by toxic metals in HLEs, we examined the induction levels of MTIIa and MTIg upon exposure to $\mathrm{Cd}^{+2}, \mathrm{Cu}^{+2}$ and $\mathrm{Zn}^{+2}$ by quantitative mimic RT-PCR. $\mathrm{Cd}^{+2}, \mathrm{Cu}^{+2}$ and $\mathrm{Zn}^{+2}$ were evaluated as inducers in these experiments since these are the metals that have been used in the majority of studies on MT and $\alpha$-crystallin/sHSP induction in non-lens systems (Head, Hurwitz, and Goldman 1996; Kagi and Schaffer 1988). MTIIa was chosen since this MT isoform exhibits increased expression in age-related cataract relative to clear human lenses (Kantorow, Kays, Horwitz, Huang, Sun, Piatigorsky, and Carper 1998b) and MTIg was chosen as a representative class I MT.

In preliminary studies, maximum MT induction occurred after 8 hour treatments with $2.8 \mu \mathrm{M} \mathrm{Cd}^{+2}, 100 \mu \mathrm{M} \mathrm{Cu}^{+2}$ and $100 \mu \mathrm{M} \mathrm{Zn}^{+2}$ (data not shown). Trypan blue exclusion detected no more than $10 \%$ cell death under these conditions (Fig. 2). Longer exposure times or higher metal concentrations resulted in decreased cell viability and consequent loss of gene expression (data not shown).

One to 2 pg of MTIIa mimic DNA equally competed with the amount of MTIIa transcript present in $300 \mathrm{ng}$ of untreated control RNA (Fig. 3). The level of MTIIa transcript present in untreated control cells is therefore between 0.003-0.006 pg per ng of total RNA. By comparison, the amount of mimic DNA required to equally compete with the amount of MTIIa transcript present in $300 \mathrm{ng}$ of RNA from $\mathrm{Cd}^{+2}$ treated cells was 10- 
$20 \mathrm{pg}$ (Fig. 3). The level of induced MTIIa transcript in $\mathrm{Cd}^{+2}$ treated cells is therefore between 0.033 to $0.067 \mathrm{pg}$ per ng of total RNA. The amount of mimic DNA required to equally compete with the amount of MTIIa transcript present in $300 \mathrm{ng}$ of RNA from $\mathrm{Zn}^{+2}$ treated cells was between 2 to $4 \mathrm{pg}$ (Fig. 3). The level of induced MTIIa transcript in $\mathrm{Zn}^{+2}$ treated cells is therefore between 0.007 to 0.013 pg per ng of total RNA.

Treatment with $\mathrm{Cu}^{+2}$ showed little or no difference in the levels of MTIIa transcript (0.003-0.006 pg per ng of total RNA) when compared to untreated control cells $(0.003-$ 0.006 pg MTIIa per ng of total RNA) (Fig. 3). These data demonstrate that MTIIa is induced in HLEs by $\mathrm{Cd}^{+2}$ (10-20 fold), and $\mathrm{Zn}^{+2}$ (2-4 fold), while $\mathrm{Cu}^{+2}$ treatment results in no induction of the MTIIa transcript.

In contrast to MTIIa, $0.1 \mathrm{pg}$ of MTIg mimic DNA equally competed with the amount of MTIg transcript present in $300 \mathrm{ng}$ of untreated control RNA. The level of MTIg transcript present in untreated control cells is therefore 0.0003 pg per ng of total RNA. The amount of mimic DNA required to equally compete with the amount of MTIg transcript present in $300 \mathrm{ng}$ of RNA from $\mathrm{Cd}^{+2}$ treated cells was approximately $1 \mathrm{pg}$ (Fig. 4). The level of MTIg transcript in $\mathrm{Cd}^{+2}$ treated cells is therefore about $0.003 \mathrm{pg}$ per ng of total RNA. The amount of mimic DNA required to equally compete with the amount of MTIg transcript present in $300 \mathrm{ng}$ of RNA from $\mathrm{Zn}^{+2}$ treated cells was between 0.1 to $0.5 \mathrm{pg}$ (Fig. 4). The level of MTIg transcript in $\mathrm{Zn}^{+2}$ treated cells is therefore between 0.0004 to 0.0018 pg per ng of total RNA. Consistent with the previous experiments, treatment with $\mathrm{Cu}^{+2}$ showed little or no difference in the levels of MTIg transcript $(0.0003$ pg per ng of total RNA) when compared to untreated control cells (0.0003 pg MTIg per ng of total RNA) (Fig. 4). 
Collectively, these data demonstrate that although the patterns of induction of MTIIa and MTIg in response to metals are similar, MTIIa is induced at 5-times higher levels than MTIg in response to these metals in HLEs. These genes exhibit specific inductions for different metals since $\mathrm{Cd}^{+2}$ and $\mathrm{Zn}^{+2}$ activate them while $\mathrm{Cu}^{+2}$ does not.

\section{Induction of MTIIa in primary human lens epithelial cells.}

To provide confidence that inductions detected for MTIIa are not restricted to the transformed SRA01/04 cells, the induction levels of MTIIa were also examined under identical conditions in untransformed primary HLEs by semi-quantitative RT-PCR (Fig. 5). In these cells, MTIIa was induced to high levels by $\mathrm{Cd}^{+2}$ and low levels by $\mathrm{Zn}^{+2}$ when compared to untreated control cells (Fig. 5). Although slight induction was detected with $\mathrm{Cu}^{+2}$ treatment (Fig. 5), these data demonstrate that similar induction patterns for MTIIa occur in untransformed primary HLEs and are likely to be paralleled in vivo.

\section{Identification of the spectrum of metallothionein and small heat-shock genes induced by $\mathrm{Cd}^{+2}, \mathrm{Cu}^{+2}$ and $\mathrm{Zn}^{+2}$ in HLEs.}

The spectrum and metal specificity for 5 of the previously identified lens MT isoforms (Oppermann, Zhang, Magabo, and Kantorow 2001b) and 3 lens $\alpha$ crystallin/sHSPs induced by $\mathrm{Cd}^{+2}, \mathrm{Cu}^{+2}$ and $\mathrm{Zn}^{+2}$ in SRA01/04 HLEs were evaluated by semi-quantitative RT-PCR. As in the previous studies (Figs. 3 and 4), MTs IIa and Ig were induced by $\mathrm{Cd}^{+2}$ and $\mathrm{Zn}^{+2}$, but not by $\mathrm{Cu}^{+2}$ (Fig. 6). MTs Ie, If and Ih were also 
induced by $\mathrm{Cd}^{+2}$ and $\mathrm{Zn}^{+2}$, but not by $\mathrm{Cu}^{+2}$ (Fig, 6). $\alpha \mathrm{B}$-crystallin and HSP27 were induced by $\mathrm{Cd}^{+2}$ and $\mathrm{Cu}^{+2}$, but not by $\mathrm{Zn}^{+2}$, and $\alpha \mathrm{A}$-crystallin was only induced by $\mathrm{Cu}^{+2}$ (Fig. 6).

\section{Analysis of 13 different metals in decapsulated human lenses.}

To establish whether metal levels change in the aging human lens, the levels of 13 different metals were evaluated by ICP. Elemental profiles in aging lenses are presented in Table 2. Sodium and potassium concentrations were highest, followed by magnesium and calcium. For other metals, zinc was found in the highest concentration, followed by iron and copper. Levels of aluminum, manganese, nickel, cadmium, chromium and lead were below the levels of detection (Table 2). Of the elements analyzed, only iron exhibited an age-dependent pattern. Iron concentration was highest in young lenses, exhibited increasing variability in middle-aged lenses, and dropped by $81 \%$ in the lenses of older individuals. 
Table 1. Primers used for RT-PCR

\begin{tabular}{|c|c|c|c|}
\hline Gene & Primer Sequence & Annealing Temp. & Accession \# \\
\hline MTIIa & AAGTCCCAGCGAACCCGCGT & 52 & J00271 \\
\hline MTIIa & CAGCAGCTGCACTTGTCCGACGC & 52 & J00271 \\
\hline MTIe & GCTCCAGCATCCCCTTTGCT & 57 & M10942 \\
\hline MTIe & CACATCAGGCACAGCAGCTG & 57 & M10942 \\
\hline MTIf & GCTTCTCTCTTGGAAAGTCC & 55 & M10943 \\
\hline MTIf & GGCATCAGTCGCAGCCGCTG & 55 & M10943 \\
\hline MTIg & GCCTCTTCCCTTCTCGCTTG & 55 & J03910 \\
\hline MTIg & GACATCAGGCGCAGCAGCTG & 55 & J03910 \\
\hline MTIh & GAACTCCAGTCTCACCTCGG & 55 & X64834 \\
\hline MTIh & GACATCAGGCACAGCAGCTG & 55 & X64834 \\
\hline$\alpha A$-crystallin & CCACCTCGGCTCCCTCGTCCTAAG & 64 & NM_000394 \\
\hline$\alpha A$-crystallin & CCATGTCCCCAAGAGCGGCACTAC & 64 & NM_000394 \\
\hline$\alpha B$-crystallin & AGCCGCCTCTTTGACCAGTTCTTC & 60 & NM_001885 \\
\hline$\alpha B$-crystallin & GCGGTGACAGCAGGCTTCTCTTC & 60 & NM_001885 \\
\hline HSP27 & CGCGCTCAGCCGGCAACTCAG & 64 & XM_055937 \\
\hline HSP27 & AGGGGTGGGCATCCGGGCTAAGG & 64 & XM_055937 \\
\hline GAPDH & CCACCCATGGCAAATTCCATGGCA & 52 & XM_006959 \\
\hline GAPDH & TCTAGACGGCAGGTCAGGTCCACC & 52 & XM_006959 \\
\hline
\end{tabular}


Table 2. Concentration of Elements in Human Lenses from Individuals of Different Ages

Age Group (mean)

\begin{tabular}{lccc}
\cline { 2 - 3 } Element & Young (32.8 y) & Middle $\mathbf{( 5 2 . 3} \mathbf{y})$ & Old (70.5 y) \\
\hline Sodium & $8267 \pm 931$ & $6632 \pm 798$ & \\
Potassium & $4479 \pm 468$ & $5478 \pm 1007$ & $8326 \pm 859$ \\
Magnesium & $176.5 \pm 3.0$ & $180.2 \pm 20.2$ & $5574 \pm 326$ \\
Calcium & $119.7 \pm 28.1$ & $78.0 \pm 21.6$ & $148.2 \pm 15.3$ \\
Zinc & $32.15 \pm 9.39$ & $25.82 \pm 3.45$ & $136.0 \pm 37.7$ \\
Iron & $12.42 \pm 0.21^{a}$ & $10.67 \pm 2.07^{a}$ & $25.79 \pm 3.96$ \\
Copper & $1.094 \pm 0.168$ & $0.677 \pm 0.029$ & $2.22 \pm 1.21^{b}$ \\
Cadmium & $\mathrm{ND}^{*}$ & $\mathrm{ND}$ & $0.949 \pm 0.304$ \\
& & & $\mathrm{ND}$ \\
\hline
\end{tabular}

Data are concentrations $(\mathrm{mg} / \mathrm{g}) \pm \mathrm{SE}(\mathrm{n}=3)$. Superscript letters denote significant differences by the Tukey-Kramer HSD comparison. Nine groups of five lenses each were digested and assessed for metal concentration by ICP and the results expressed in micrograms of metal per gram of dry lens. ND, not detectable.

* Below the level of detection $(<0.191 \mathrm{mg} / \mathrm{L})$. 
Figure 1. Schematic representation of the MTIIa PCR mimic (A). A 138 bp internal sequence $(+18$ to +155 , from the start of translation) was deleted from the MTIIa cDNA to create the $99 \mathrm{bp}$ MTIIa PCR mimic. Shown for comparison is the full-length $237 \mathrm{bp}$ MTIIa cDNA. Schematic representation of the MTIg PCR mimics (B). A 118 bp internal sequence $(+18$ to +135 , from the start of translation) was deleted from the MTIg cDNA to create the 99 bp MTIg PCR mimic. Shown for comparison is the full-length 217 bp MTIg cDNA. Indicated are the primer binding sites. 
A.

\section{Product \\ Size \\ 99 bp}

237 bp

B.

Product

Size

99 bp

217 bp

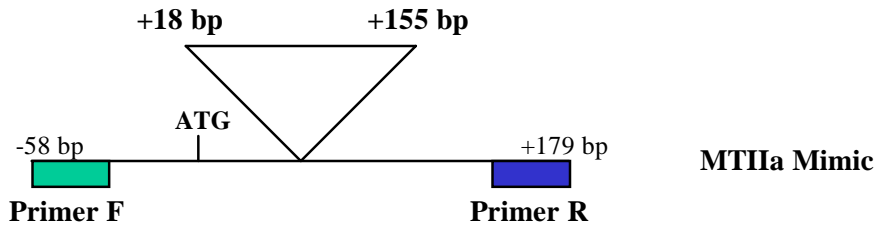

$\underbrace{-58 \mathrm{bp}}_{\text {Primer F }} \stackrel{\text { ATG }}{\text { Frimer R }}$ MTIIa cDNA

$-47 \mathrm{bp}$
$\square$
Primer F


Figure 2. Cell toxicity resulting from $\mathrm{Cd}^{+2}, \mathrm{Cu}^{+2}$ and $\mathrm{Zn}^{+2}$ treatment of HLEs at indicated metal concentrations. HLEs were treated with indicated metals for 8 hours and cell death was examined by trypan blue exclusion. Values represent the averages and standard deviations of three separate experiments. 


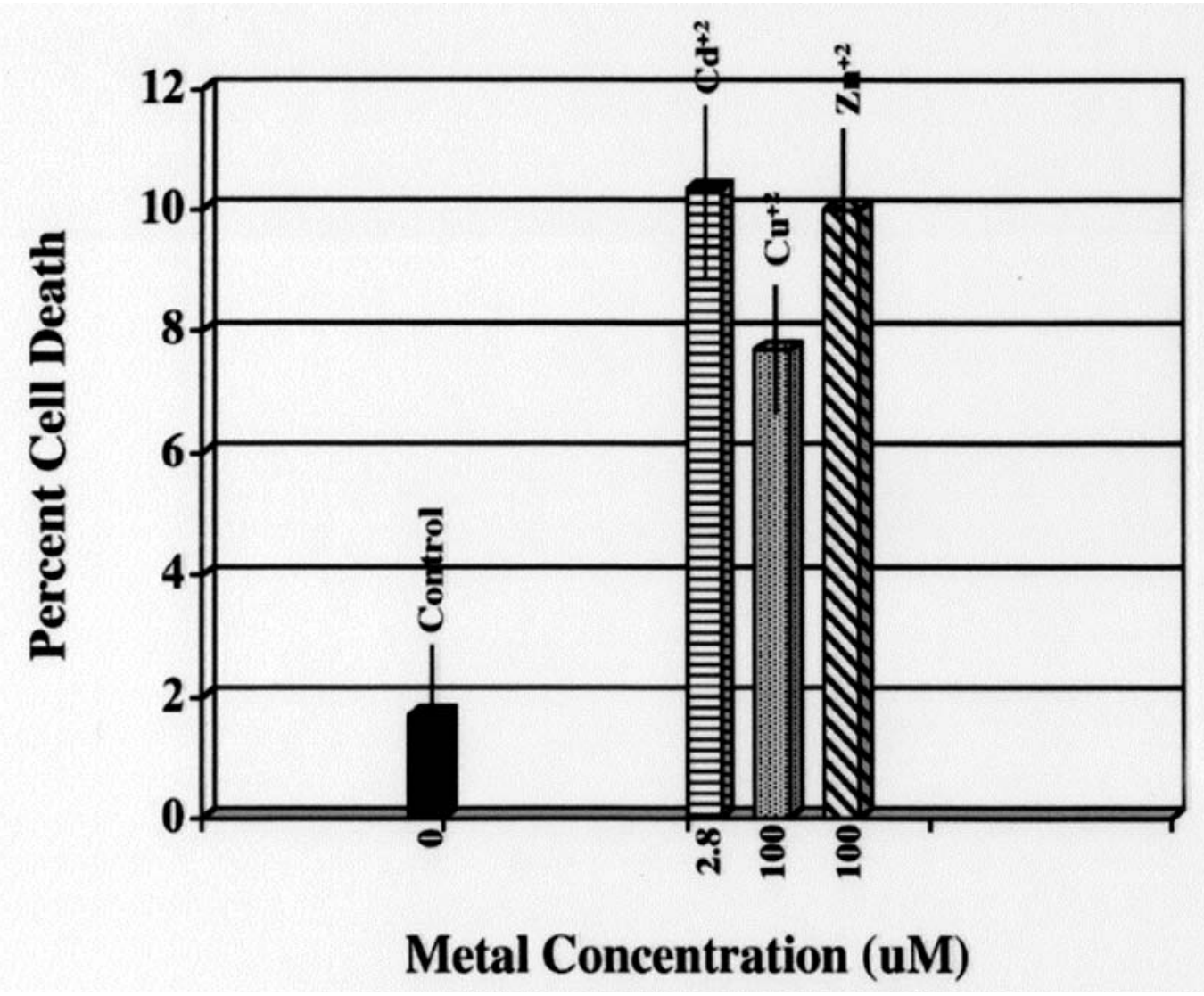


Figure 3. Ethidium bromide stained gels showing quantitative mimic RT-PCR analysis of MTIIa induced after 8 hours of $\mathrm{Cd}^{+2}, \mathrm{Cu}^{+2}$ or $\mathrm{Zn}^{+2}$ treatment. $300 \mathrm{ng}$ of RNA were amplified in the presence of increasing amounts (0-500 pg) of competing MTIIa mimic DNA. Indicated are the metal concentrations, the 237 bp MTIIa cDNA, the 99 bp MTIIa mimic PCR products and the calculated radioactivity incorporated in each PCR product. 

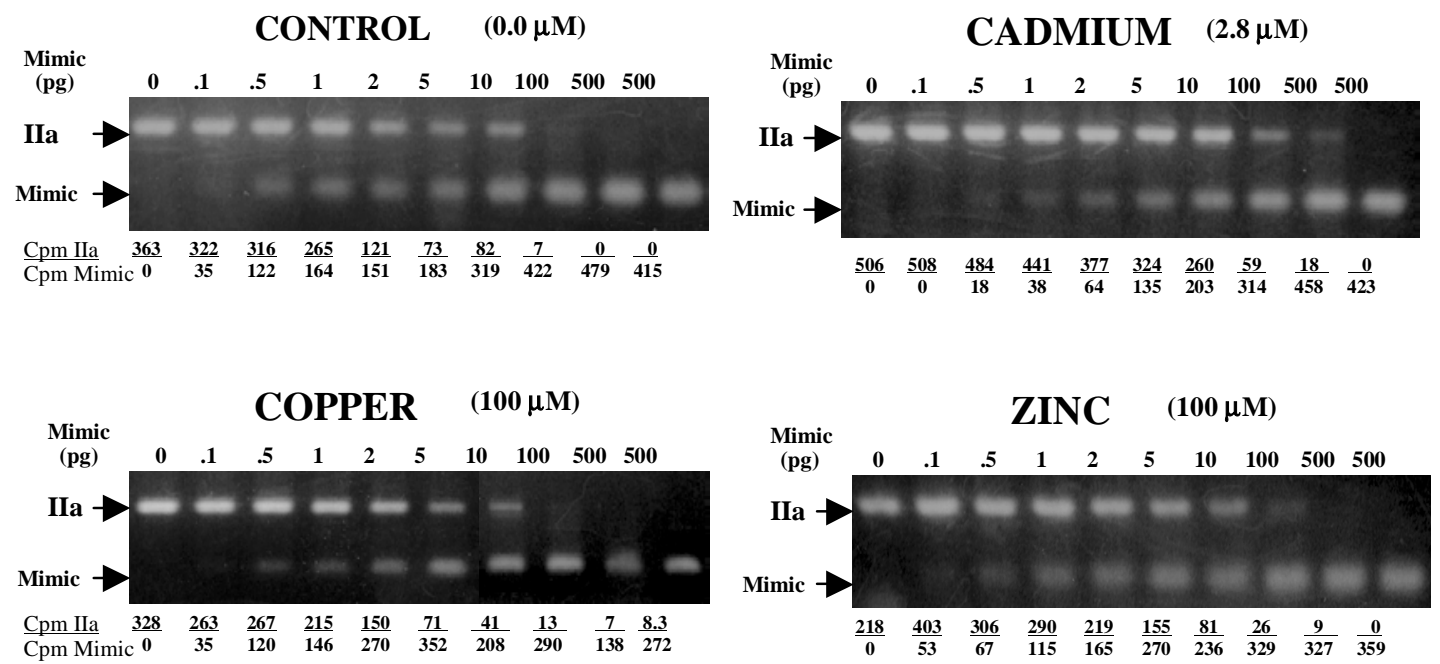
Figure 4. Ethidium bromide stained gels showing quantitative mimic RT-PCR analysis of MTIg induced after 8 hours of $\mathrm{Cd}^{+2}, \mathrm{Cu}^{+2}$ or $\mathrm{Zn}^{+2}$ treatment. $300 \mathrm{ng}$ of control RNA was amplified in the presence of increasing amounts (0-500 pg) of competing MTIg mimic DNA. Indicated are the metal concentrations, the $217 \mathrm{bp}$ MTIg cDNA and the 99 bp MTIg mimic PCR products. 


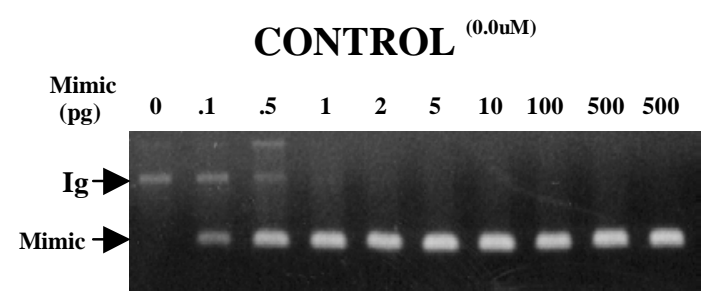

COPPER ${ }^{(100 \mathrm{uM})}$

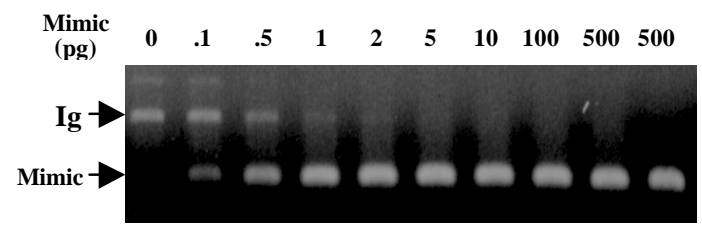

\section{CADMIUM $^{(2.8 \mathrm{uM})}$}

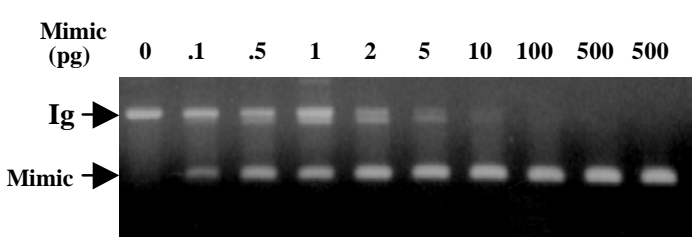

ZINC ${ }^{(100 u M)}$

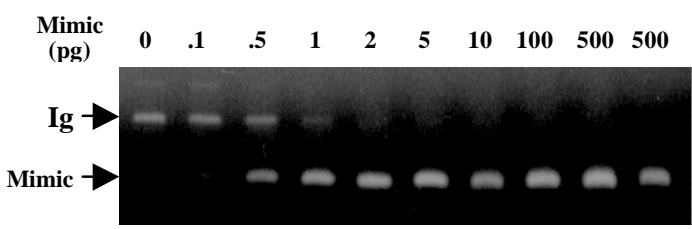


Figure 5. Ethidium bromide stained gel showing the levels of MTIIa detected by RTPCR in 50 ng of RNA isolated from primary human lens epithelial cells induced by $\mathrm{Cd}^{+2}$, $\mathrm{Cu}^{+2}$ and $\mathrm{Zn}^{+2}$ for 8 hours at the indicated concentrations for a total of 28 PCR cycles. Shown as control are the corresponding GAPDH levels. 


\section{MTIIa}

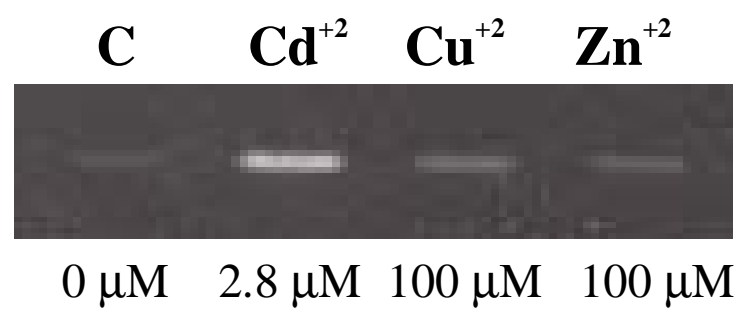

\section{GAPDH}

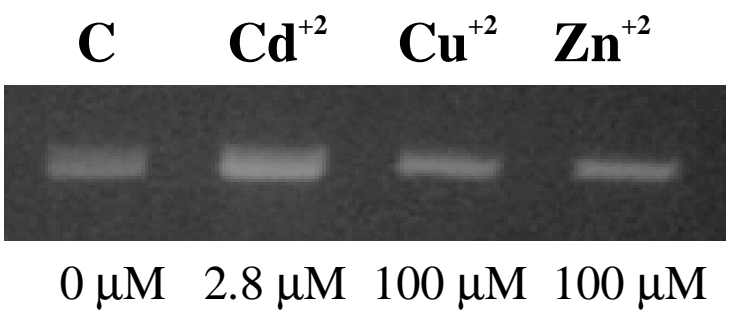


Figure 6. Ethidium bromide stained gels showing the levels of metallothionein and small heat-shock genes detected by RT-PCR in 100 ng of RNA isolated from HLEs induced by $\mathrm{Cd}^{+2}, \mathrm{Cu}^{+2}$ and $\mathrm{Zn}^{+2}$ for 8 hours at the indicated concentrations. 


\section{Metallothionein Genes}

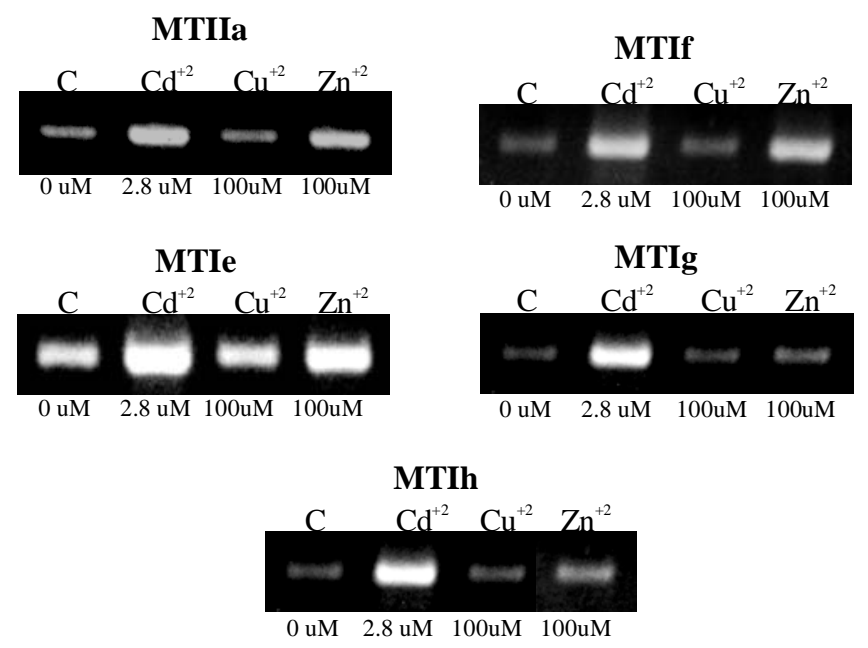

Small Heat Shock Genes

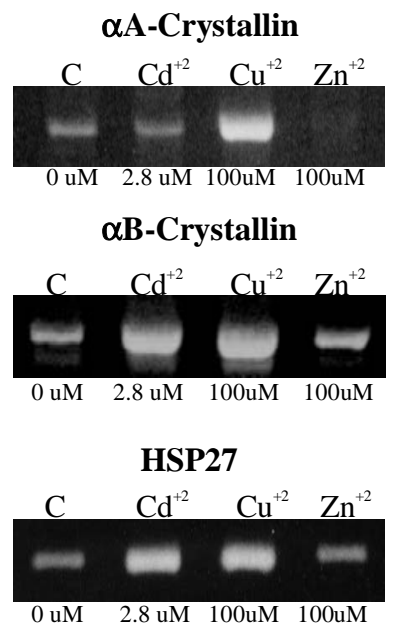




\section{DISCUSSION}

The present data demonstrate that 5 MTs previously demonstrated to be expressed by the human lens (Oppermann, Zhang, Magabo, and Kantorow 2001b), including isoforms Ie, If, Ig, Ih and IIa, and 3 lens $\alpha$-crystallin/sHSPs, including $\alpha$ A-crystallin, $\alpha \mathrm{B}$ crystallin and HSP27, are differentially induced by specific metals in HLEs. These inductions are likely to be present in vivo, since similar inductions were observed for MTIIa in primary cultures of HLEs. To our knowledge, this is the first demonstration of $\alpha$ A-crystallin induction by metals or other stresses and provides evidence that $\alpha \mathrm{A}-$ crystallin could be a stress-responsive gene that protects lens cells against metalassociated damage.

Activation of these genes is metal-specific in HLEs since $\mathrm{Cd}^{+2}$ and $\mathrm{Zn}^{+2}$, but not $\mathrm{Cu}^{+2}$, induced the MT genes (Ie, If, Ig, Ih and IIa) while $\mathrm{Cd}^{+2}$ and $\mathrm{Cu}^{+2}$, but not $\mathrm{Zn}^{+2}$, induced 2 of the $3 \alpha$-crystallin/sHSP genes ( $\alpha$ B-crystallin and HSP27). $\alpha$ A-crystallin induction was only observed upon $\mathrm{Cu}^{+2}$ exposure. The differential induction of these genes by specific metals indicates that the encoded proteins are likely to have different roles in lens regulation of, and/or protection against, specific metals.

MTIIa was induced at 5-times higher levels than MTIg, indicating that MTIIa is the primary MT responding to metals in lens cells. This is consistent with its reported increased expression in age-related cataract relative to clear lenses (Kantorow, Kays, Horwitz, Huang, Sun, Piatigorsky, and Carper 1998b) and its lens epithelium specificity (Oppermann, Zhang, Magabo, and Kantorow 2001b).

The present data address the induction of these genes at concentrations of metals that result in no more than $10 \%$ cell death over a relatively short incubation time. We cannot examine higher levels of these metals or longer exposure times since significant 
cell lethality, and consequent loss of gene expression, was observed with higher metal concentrations or with longer exposure times (data not shown).

Differential induction of these genes by specific metals suggests that the lens may employ metal-specific transcriptional mechanisms to regulate specific genes. These responses are likely mediated by previously identified metal-responsive transcription factors. One of these, that is known to regulate the expression of mouse MTs I and II in non-lens cells by binding to metal responsive regulatory elements (MREs) in the promoters of these genes, is the metal response element-binding transcription factor-1 (MTF-1) (Gunes et al 1998). MTF-1 has been shown to activate the expression of MTs I and II by specific heavy metals including $\mathrm{Cd}^{+2}$ and $\mathrm{Cu}^{+2}$ (Heuchel et al 1994). MTF-1null mice lose their ability to express MTs I and II (Heuchel, Radtke, Georgiev, Stark, Aguet, and Schaffner 1994). Like the MTs, the promoters for the $\alpha$-crystallin/sHSPs, including $\alpha \mathrm{B}$-crystallin and HSP27, are known to contain binding sites for multiple stress-related transcription factors including a near perfect MRE that is located in the promoter of the rat $\alpha \mathrm{B}$-crystallin gene (Head, Hurwitz, and Goldman 1996). They also contain other stress-associated regulatory elements including heat shock responsive elements (HSEs) and AP1-like consensus sequences (Frederikse PH 1994; Iwaki et al 1990; Srinivasan and Bhat 1994).

Multiple studies suggest that numerous metals are associated with cataract (Cuthbert 1998; Girelli, Corrocher, Bisceglia, Olivieri, De Franceschi, Zelante, and Gasparini 1995; Phelps Brown 1996; Ramakrishnan, Sulochana, Selvaraj, Abdul, Lakshmi, and Arunagiri 1995) and increased $\mathrm{Cd}^{+2}$ levels have been demonstrated in cataract versus clear human lenses (Ramakrishnan, Sulochana, Selvaraj, Abdul, Lakshmi, and Arunagiri 1995). Although intact cataract lenses are not readily available, and no 
conclusions regarding the presence of metals in human cataracts can be drawn from the present results, no differences were detected in the levels of 12 metals between young, middle-aged and old healthy lenses. In contrast to the data reported for human cataract (Ramakrishnan, Sulochana, Selvaraj, Abdul, Lakshmi, and Arunagiri 1995), cadmium was not even detectable in the clear lenses analyzed in the present report suggesting that increased cadmium levels are specific to cataractous lenses. We did, however, detect an $81 \%$ decrease in iron levels between young and middle-aged versus old human lenses. Although altered iron regulation is associated with cataract (Phelps Brown 1996), the significance of this result is open to speculation. We do not think that decreased iron results from sample contamination since no differences were detected in the 12 other metals examined; 3 separate groups of 5 lenses revealed similar iron levels and contamination is very unlikely to be reflected in the decreased level of iron detected in a single group. Although the lens capsule was excluded from the lens metal contents reported, we are certain that our results would not be affected by inclusion of the lens capsule since its weight is insignificant relative to that of the rest of the lens. Relative to the sensitivity of presently available techniques, the extremely large number of human lens epithelia/capsules that would be required to assay the metal content of this tissue (approximately 0.3 grams) makes this examination unfeasible.

Future studies will be needed to determine the exact function for MTs and $\alpha$ crystallin/sHSPs induction in human lens cells. It is likely that MTs are capable of protecting these cells against damage induced by toxic metals and possibly other insults associated with cataract since metallothioneins have been shown to protect numerous tissues, including retinal pigment epithelial cells (Lu, Hunt, Ganti, Davis, Dutt, Alam, and Hunt 2002), against toxic metals, oxidative stress and UV-light insults. MTs are 
likely to protect lens cells through direct metal binding and scavenging of free-radicals as they have been demonstrated to do in non-lens systems. Indeed, it is estimated that MTs are 50-times more efficient as free-radical scavengers than reduced glutathione on a molar basis (Miura et al 1997). The present data also provide evidence that $\alpha$ crystallin/sHSPs may have a role in lens metal protection. $\alpha$-crystallin/sHSPs protect against protein aggregation and it is possible that they are induced in response to metals to prevent protein aggregation or other damage resulting from metal exposure.

Regardless of their exact functions, the inductions of these genes in human lens cells indicate that they are likely to play significant roles in lens metal regulation and/or protection and future studies will examine their ability to directly protect lens cells against metals and other cataract-associated insults. 


\section{Chapter VII}

Methionine sulfoxide reductase A protects human eye lens cells against oxidative stress damage

*John R. Hawse, *Marc Kantorow, Tracy L. Cowell, Sonia Benhamed, Gresin O. Pizarro, Venkat N. Reddy, J. F. Hejtmancik

* Authors contributed equally to this work 


\begin{abstract}
Age-related cataract, an opacity of the eye lens, is the leading cause of visual impairment in the elderly and oxidative stress damage is believed to be a major factor in cataract formation. One major feature of age-related cataract is oxidation of lens methionines that approach levels as high as $60 \%$ in cataract relative to clear human lenses. Methionine oxidation results in loss of protein function but can be reversed through the action of methionine sulfoxide reductase A (MsrA) which has been directly implicated in oxidative stress protection and is an essential regulator of longevity in species ranging from $E$. coli to mice. To establish a potential role for MsrA in protection of the lens against oxidative stress we have examined the levels and spatial expression patterns of MsrA in the human lens and tested the ability of MsrA to directly protect lens cells against oxidative stress insult. In the present report, we establish that MsrA is abundantly expressed in the lens relative to other human tissues and is present throughout the human lens where it is likely to defend lens cells and their components against methionine oxidation. We demonstrate that over-expression of MsrA directly protects lens cells against oxidative stress damage while silencing of the MsrA gene renders lens cells more sensitive to oxidative stress damage. Collectively, these data implicate MsrA as a key player in lens protection against oxidative stress and in cataract formation.
\end{abstract}




\section{INTRODUCTION}

Age-related cataract is an opacity of the eye lens that is the major cause of world blindness (Kupfer 1994). The lens consists of a single layer of epithelial cells that cover concentric layers of elongated fiber cells. The fiber cells of the lens do not turnover and are some of the oldest cells in the body. Damage to lens cells and their components ultimately results in protein aggregation and cataract. Among the many factors involved in cataract formation, oxidative stress plays a major role through the oxidation and subsequent aggregation of lens proteins (Bodaness et al 1984; McNamara and Augusteyn 1984; Smith et al 1997a; Zigler, Jr. et al 1989). One major protein modification associated with oxidative stress in the lens is oxidation of methionine residues to methionine sulfoxide. Methionine sulfoxide is barely detectible in young lenses but increases in the lens with age (Spector 1995). Compellingly, in cataract relative to clear healthy lenses as much as $60 \%$ of membrane bound methionines are present in an oxidized form (Garner and Spector 1980). Although it has been established that numerous important oxidative stress and other defense systems function in the lens including $\alpha$-crystallin (Horwitz 1992), MnSOD (Matsui et al 2003), CuZnSOD (Behndig et al 2001), reduced glutathione (Harding et al 1996; Packer 1995; Rathbun et al 1993), glutathione reductase (Ikebe et al 1989), glutathione s-transferase (Yang et al 2002), thioltransferase (Xing and Lou 2002), catalase (Spector, Li, Ma, Sun, and Pavlidis 2002) and others, most of these systems are protective, do not reverse oxidative stress damage and none work directly on oxidized methionines. Oxidation of methionine residues is associated with the loss of numerous protein activities and effects a multitude of biological functions (Brot et al 1981; Caldwell et al 1978; Ciorba et al 1997; Johnson and Travis 1979; Swaim and Pizzo 1988; Vogt 1995). Thus, any protective system that could 
prevent methionine oxidation and/or repair oxidized methionines would likely play a major role in lens maintenance and cataract formation.

Unlike most protein modifications, methionine sulfoxides can be converted back to reduced methionine through the action of a class of enzymes known as methionine sulfoxide reductases (Msrs) (Weissbach et al 2002) in a thioredoxin-dependent reaction involving both thioredoxin reductase and NADPH (Moskovitz et al 1996; Moskovitz et al 1997b). The Msr system is a key repair and defense system that is conserved throughout evolution and dictates lifespan in species ranging from E. coli to mice. Oxidation of methionine residues results in two forms of methionine sulfoxide, an S- and R- form. Two separate classes of Msrs, referred to as MsrA and MsrB, have been identified that repair the S- and R-forms of methionine sulfoxide residues respectively (Weissbach, Etienne, Hoshi, Heinemann, Lowther, Matthews, St John, Nathan, and Brot 2002). Overexpression of MsrA in transgenic flies renders them more resistant to oxidative stress and dramatically increases their lifespan (Ruan et al 2002) and confers direct protection against peroxide-mediated oxidative stress in yeast and human T-lymphocytes (Moskovitz et al 1998a). E. coli and yeast lacking MsrA are more sensitive to oxidative stress (Moskovitz et al 1995; Moskovitz et al 1997a) and deletion of the MsrA gene in mice results in increased sensitivity of these animals to oxidative stress in the form of $100 \%$ oxygen treatment, shortens their lifespan by $10 \%$ under normal conditions and by $50 \%$ under hyperoxic conditions and causes neurological impairment in conjunction with an increase in oxidized methionine content (Moskovitz et al 2001).

Increased methionine oxidation of lens proteins with age and in age-related human cataract suggests that loss of Msr function is associated with age-related cataract and that Msrs are likely to play key roles in defending the lens against oxidative stress 
damage. Significant MsrA activity has been detected in the lens epithelia, cortex and nucleus (Spector et al 1982) however, to date, the role of Msrs in the lens or in the development of age-related cataract has not been examined. As a first step toward elucidating the role of Msrs in lens function, we have examined the levels and spatial expression patterns of MsrA in the human lens and have tested the ability of the enzyme to directly protect human lens cells against oxidative stress damage. The results reveal that high levels of MsrA transcript and protein are found throughout the lens and suggest that MsrA is capable of directly protecting lens cells against oxidative stress-induced damage. 


\section{RESULTS}

\section{MsrA mRNA is highly expressed by the human lens.}

To determine the relative levels of MsrA expression in the human lens, RNA was isolated from 5 whole human lenses and MsrA transcript levels were compared with 18 other human tissues by semi-quantitative RT-PCR followed by densitometric analysis. MsrA transcript was detected in all of the 19 tissues (Fig. 1A) suggesting ubiquitous MsrA expression in humans. The highest levels were detected in the spleen (4.92) while smooth muscle tissue exhibited the lowest levels (0.04) (Fig. 1B). MsrA was expressed at the forth highest level in whole human lenses (2.41) relative to the other tissues types examined (Fig. 1B).

\section{MsrA transcript and protein are expressed by the human lens.}

Whole human lenses were microdissected and RNA was prepared from the lens epithelium and fiber cells and protein was extracted from lens epithelial, cortical and nuclear fiber cells. MsrA transcript was detected in both the lens epithelium and fiber cells by semi-quantitative RT-PCR (Fig. 2A). MsrA transcript was estimated to be expressed at approximately 2-fold higher levels in the lens epithelium relative to fiber cells after normalizing the PCR products to the corresponding GAPDH levels (Fig. 2A). Consistent with the transcript levels, MsrA protein was detected in the lens epithelium, cortical and nuclear fibers by western analysis (Fig. 2B). As with the western analysis, 
immunohistochemical staining suggests that MsrA is abundant in the lens epithelium with decreased levels in the cortical and nuclear fiber cells (Fig. 3 A and B).

\section{Over-expression of exogenous MsrA in HLEs confers resistance to $\mathrm{H}_{2} \mathrm{O}_{2}$-induced oxidative damage.}

To determine the ability MsrA to confer resistance to $\mathrm{H}_{2} \mathrm{O}_{2}$-induced oxidative stress in human lens epithelial cells, MsrA over-expressing cell lines were created and exposed to $\mathrm{H}_{2} \mathrm{O}_{2}$. The over-expressing cells have increased levels of MsrA mRNA (Fig. 4A) and protein (Fig. 4B) relative to control cells. Over-expression of MsrA protected HLEs against $\mathrm{H}_{2} \mathrm{O}_{2}$ induced stress by as much as $40 \%$ over concentrations ranging from $800 \mu \mathrm{M}-950 \mu \mathrm{M}$ relative to control cells (Fig. 4C) and a separate retrovirally transformed cell line that does not over-express MsrA.

\section{Silencing of endogenous MsrA causes increased sensitivity of HLEs to $\mathrm{H}_{2} \mathrm{O}_{2}$ induced oxidative damage.}

The effects of decreased endogenous MsrA on the sensitivity of HLEs exposed to $\mathrm{H}_{2} \mathrm{O}_{2}$ was examined by siRNA gene silencing. Significant decreases in MsrA transcript levels were detected within 24,48 and 72 hours posttransfection relative to mock transfected control cells (Fig. 5A). Silencing of endogenous MsrA rendered HLEs more sensitive to $\mathrm{H}_{2} \mathrm{O}_{2}$-induced stress at concentrations ranging from $570 \mu \mathrm{M}$ to $720 \mu \mathrm{M}$ by approximately $25 \%$ relative to mock transfected cells (Fig. 5B). The differences in cell viability are not due to the presence of double-stranded RNA molecules since identical 
differences were obtained when transfecting lens cells with a siRNA construct that is ineffective at reducing the transcript levels of MsrA. Interestingly, decreased MsrA levels resulted in reduced lens cell viability by approximately $20 \%$ in the absence of $\mathrm{H}_{2} \mathrm{O}_{2}$ (Fig. 5B) suggesting that MsrA is required for normal lens cell function. 
Figure 1. Analysis of MsrA transcript levels in 19 different human tissues. A). Ethidium bromide-stained gels showing the levels of MsrA in $100 \mathrm{ng}$ of RNA isolated from the indicated tissues. B). Table of corresponding densitometry values. 
A)
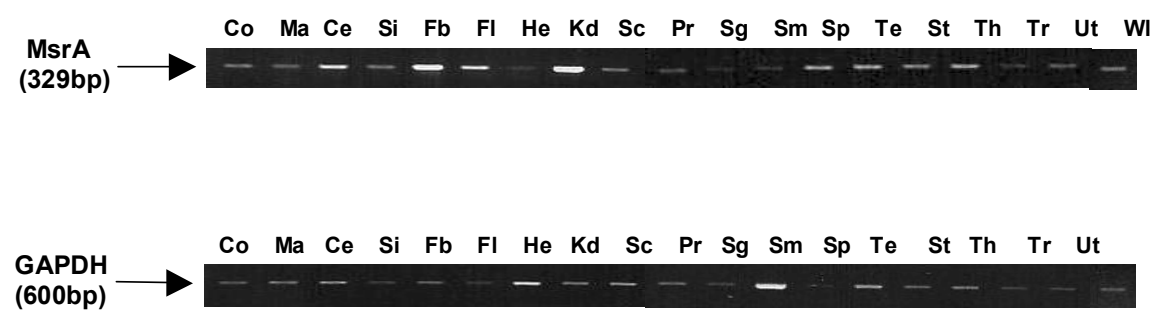

B)

\begin{tabular}{|l|c|c|c|c|}
\hline \multicolumn{1}{|c|}{ Tiss ue } & M srA & GA P D H & A djusted M s rA /G A P D H & R a nk \\
\hline \hline & & & & 1.03 \\
\hline Colon(Co) & 11.6 & 11.2 & 0.71 & 9 \\
\hline B.M arrow(Ma) & 9.7 & 13.6 & 1.27 & 12 \\
\hline Cerebellum(Ce) & 21.9 & 17.3 & 1.05 & 6 \\
\hline S.Intestine(Si) & 11.2 & 10.7 & 2.69 & 8 \\
\hline Fetal Brain(Fb) & 39.8 & 14.8 & 2.3 & 2 \\
\hline Fetal Liver(FI) & 20.5 & 8.9 & 0.16 & 5 \\
\hline Heart(He) & 4.7 & 29.3 & 2.65 & 17 \\
\hline Kidney(Kd) & 47.1 & 17.8 & 0.63 & 3 \\
\hline S.Cord(Sc) & 13.3 & 21.2 & 0.44 & 14 \\
\hline Prostate(Pr) & 5.3 & 12.1 & 0.41 & 16 \\
\hline S.gland(Sg) & 2.4 & 5.8 & 0.04 & 17 \\
\hline S.muscle(Sm) & 3.4 & 80.1 & 4.92 & 19 \\
\hline Spleen(Sp) & 12.8 & 2.6 & 0.56 & 1 \\
\hline Testis(Te) & 13.5 & 23.9 & 0.96 & 15 \\
\hline Stomach(St) & 10 & 10.4 & 0.95 & 10 \\
\hline Thyro id(Th) & 13.6 & 14.2 & 0.64 & 11 \\
\hline Trachea(Tr) & 3.5 & 5.5 & 1.23 & 13 \\
\hline Uterus(Ut) & 6.4 & 5.2 & $\mathbf{2 . 4 1}$ & 7 \\
\hline Whole Le ns(WI) & $\mathbf{2 3 . 9}$ & $\mathbf{9 . 9}$ & & $\mathbf{4}$ \\
\hline
\end{tabular}


Figure 2. Spatial analysis of MsrA transcript and protein levels in micro-dissected human lenses. A). Ethidium bromide-stained gels showing the relative levels of MsrA transcript between micro-dissected lens epithelial cells and fiber cells. B).

Immunoblotting of lens epithelium (E), cortex (C) and fiber (F) extracts with a MsrAspecific antibody using (15 ug) of protein. The blot and corresponding Coomassie stained gel are shown. 
A.
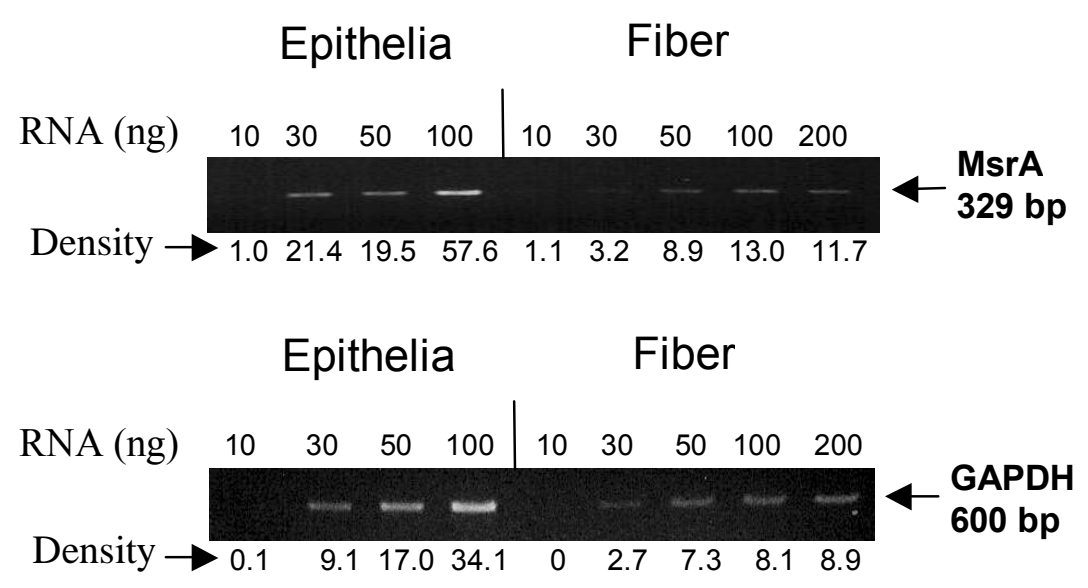

B.
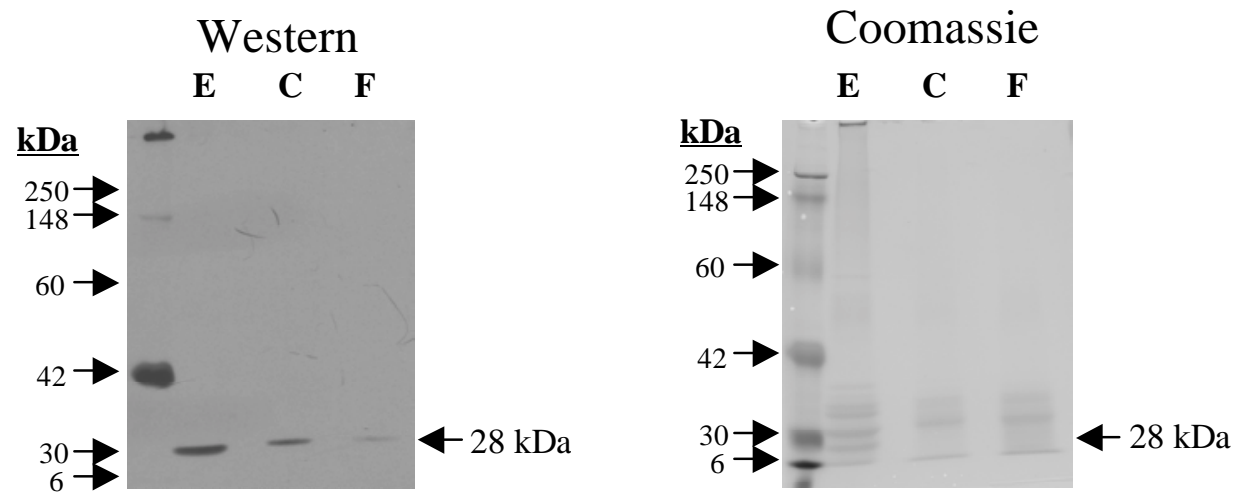
Figure 3. Immunostaining of adult human lens with MsrA-specific antibody. An 18year-old female human lens was immunostained with anti-MsrA antibody (A and C) or secondary antibody alone (B and D). Peripheral (A and B) and posterior (C and D)

portions of the lens are shown. Lens capsule (Cap), epithelium (Epi) and fibers (Fib) are indicated. 


\section{A}

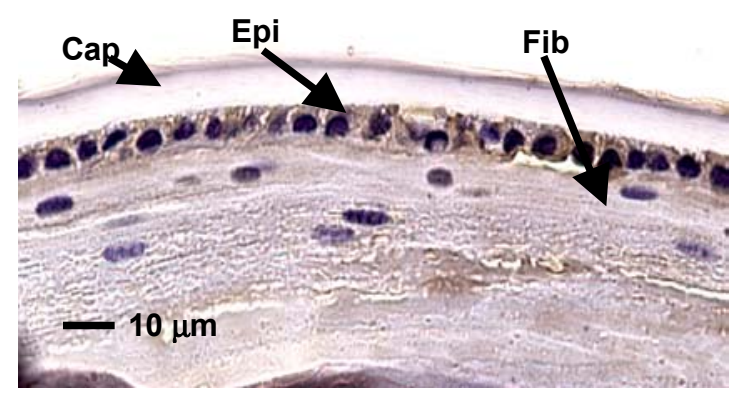

C

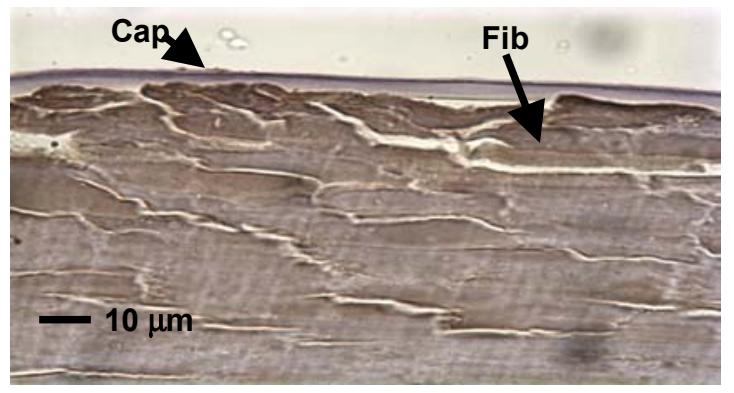

B

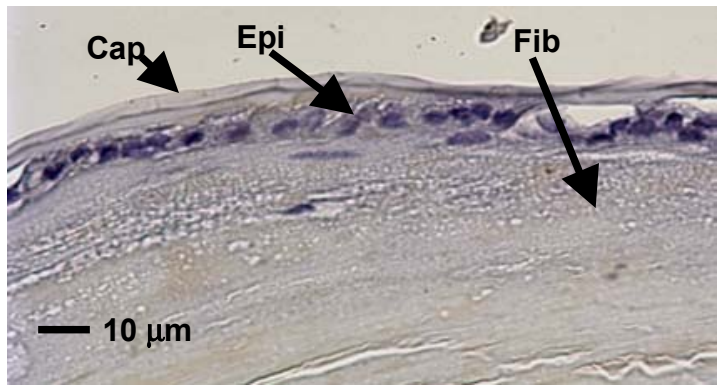

D

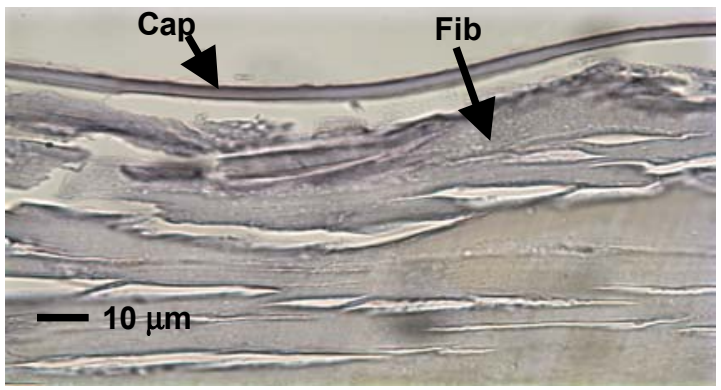


Figure 4. Over-expression of MsrA in human lens epithelial cells (SRA01/04). A). Ethidium bromide stained gel showing the relative levels of MsrA detected between two separately constructed over-expressing cell lines (\# 1 and \#2) compared to control cells (C). B). Immunoblotting of $15 \mu \mathrm{g}$ of protein extracts from control cells (C) and the two MsrA over-expressing cell lines (\#1 and \#2) with a mouse monoclonal antibody raised against the 14 amino acid V5 epitope fused to the C-terminal end of the recombinant MsrA protein. C). Representative graphs depicting increased resistance to $\mathrm{H}_{2} \mathrm{O}_{2}$ stress treatments of the two MsrA over-expressing cell lines (yellow lines) relative to control cells (blue lines) using MTS cell viability assays. $\mathrm{H}_{2} \mathrm{O}_{2}$ treatments were conducted for 24 hours in serum free media. The absorbance readings and $\mathrm{H}_{2} \mathrm{O}_{2}$ concentrations used are indicated. 


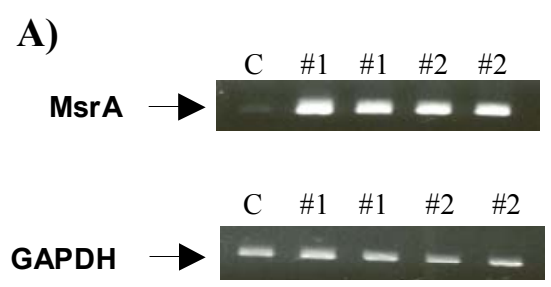

C)

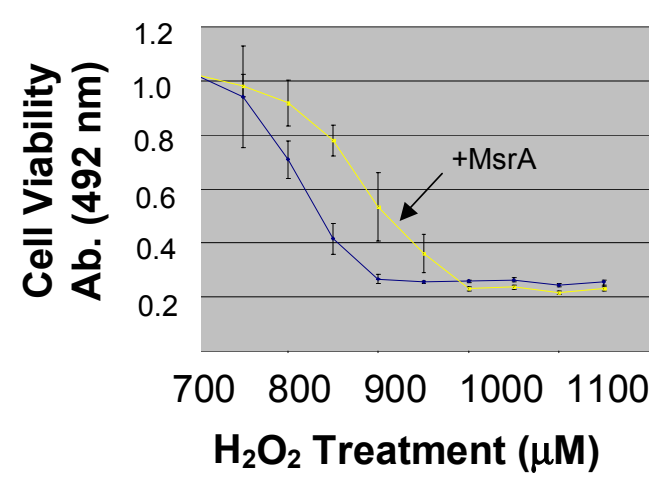

B)
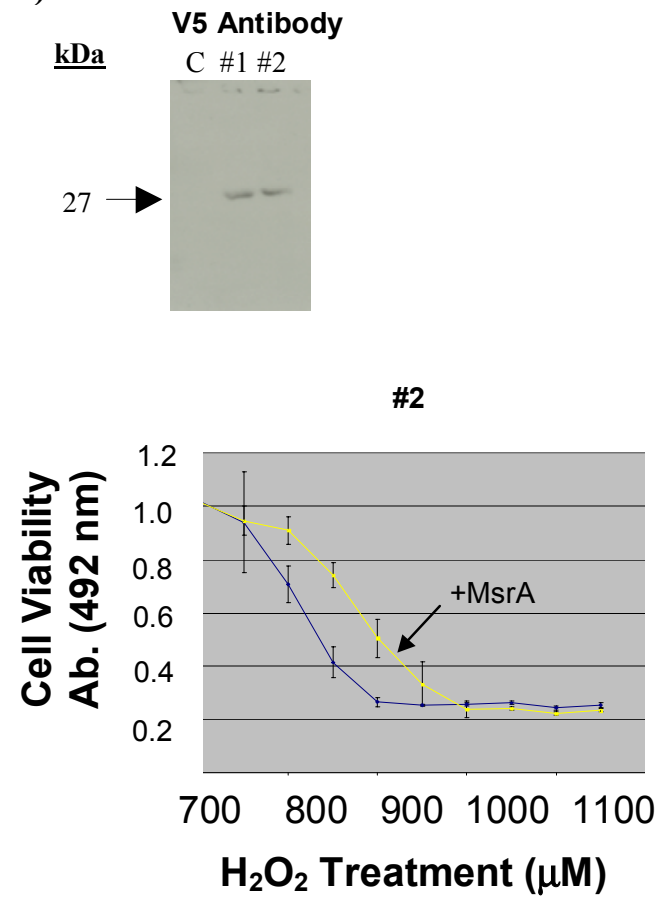
Figure 5. siRNA mediated MsrA gene suppression in human lens epithelial cells (SRA01/04). A). Ethidium bromide stained gel showing MsrA specific gene suppression at 24,48 and 72 hours post-transfection of siRNA relative to mock transfected control cells (C). B). Representative graph depicting decreased resistance to $\mathrm{H}_{2} \mathrm{O}_{2}$ stress 48 hours post-transfection of siRNA (yellow line) relative to mock transfected control cells (blue line) using MTS cell viability assays. Untransfected cells are represented by "U”. $\mathrm{H}_{2} \mathrm{O}_{2}$ treatments were conducted for 24 hours in serum free media. The absorbance reading and $\mathrm{H}_{2} \mathrm{O}_{2}$ concentrations used are indicated. 
A)

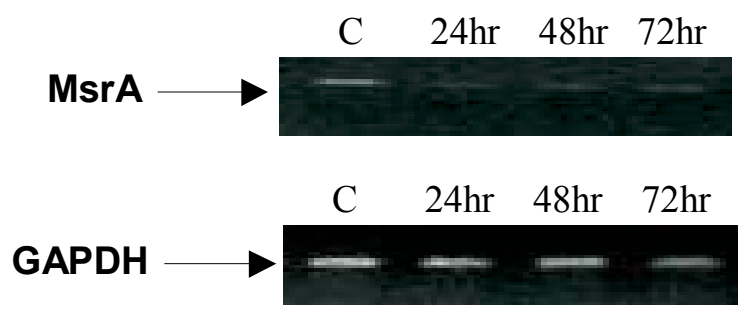

B)

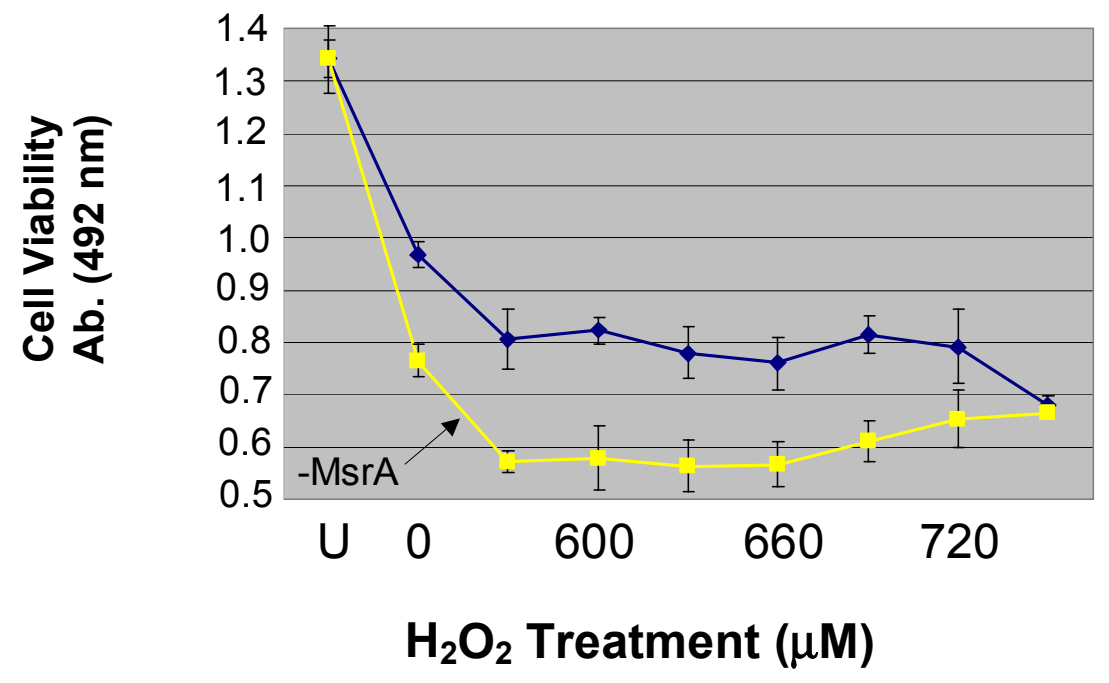




\section{DISCUSSION}

The present data establish that MsrA is expressed at the fourth highest level in the human lens relative to 18 different human tissues. Only the spleen, fetal brain and kidney exhibited higher levels of expression suggesting an important role for MsrA in lens maintenance. High levels of MsrA transcript and protein were detected in the lens epithelium, and in the cortical and nuclear fibers where there is no protein turnover suggesting a role for MsrA in defending this region of the lens against oxidation. MsrA has previously been shown to play a role in defense against oxidative stress in multiple non-lens systems (Singh and Moskovitz 2003; St John et al 2001; Yermolaieva et al 2004a). Here, we demonstrate that increased expression of MsrA protects lens cells from $\mathrm{H}_{2} \mathrm{O}_{2}$-induced oxidative stress while decreased expression of MsrA results in increased sensitivity to $\mathrm{H}_{2} \mathrm{O}_{2}$-induced oxidative stress.

MsrA transcript exhibited approximately 2-fold higher levels in the lens epithelium compared to the terminally differentiated lens fiber cells by semi-quantitative RT-PCR (Fig. 2A). MsrA protein was also present at the highest levels in the lens epithelium compared to cortical fibers with detectable but lower levels present in the nucleus of the lens (Fig. 2B). Immunohistochemical staining for MsrA in a whole human lens paralleled the western analysis of MsrA protein in micro-dissected portions of the lens as intense staining specific for MsrA was observed in the lens epithelium with lower levels detected in the cortical fibers (Fig. 3 A and B). The high levels of MsrA expression in the lens epithelium correlates with the expression patterns of many other enzymes in the lens and points to an important role for MsrA in protection of lens epithelial cells against oxidative stress. The lens epithelium is essential for the growth, differentiation, and homeostasis of the entire organ (Bloemendal H 1981; Piatigorsky 
1981b), contains the highest levels of enzymes and transport systems in the lens (Reddan JR 1982; Reddy 1971a; Spector 1982b) and is also the first part of the lens exposed to oxidative stress (Reddan JR 1982; Spector 1982b). Multiple studies suggest that the lens epithelium is capable of communicating with the underlying fiber cells (Bassnett et al 1994; Rae et al 1996a) and direct damage to the lens epithelium and its enzyme systems is known to result in cataract formation (Harding JJ 1984; Hightower 1995; Phelps Brown 1996; Spector 1995). Importantly, oxidative damage to the lens epithelium is believed to be an initiating factor of cataractogenesis (Spector 1995). The high abundance of MsrA in the lens epithelium provides evidence that MsrA plays an important role in defending this lens region against oxidative stress insult.

Very intense staining for MsrA was also observed in the posterior fiber cells of the lens (Fig. $3 \mathrm{C}$ and D) suggesting a particular function for MsrA in the lens fibers which are particularly prone to oxidative stress damage since they do not turnover and are incapable of replenishing damaged proteins. The high levels of MsrA expression in these cells suggest that the enzyme is involved in the long term repair and maintenance of fiber cell protein most notably, the crystallins which constitute approximately $40 \%$ of the wet weight of the lens and are primarily responsible for lens transparency (Delaye and Tardieu 1983).

Previous studies have revealed the ability of MsrA over-expression to aid cells in defense against oxidative stress-induced damage including protection of PC12 cells from hypoxia induced cell death (Yermolaieva et al 2004b) and human T lymphocytes against the cytotoxic effects of $\mathrm{H}_{2} \mathrm{O}_{2}$ stress (Moskovitz et al 1998b). Here we extend these studies to demonstrate that exogenous expression of MsrA in human lens epithelial cells confers resistance to $\mathrm{H}_{2} \mathrm{O}_{2}$ induced oxidative damage. Over-expression of MsrA to levels 
approaching a 10-fold increase relative to control cells (Fig. 4A) resulted in as much as a $40 \%$ increase in cell viability compared to control cells over $\mathrm{H}_{2} \mathrm{O}_{2}$ concentrations ranging from $800 \mu \mathrm{M}$ to $950 \mu \mathrm{M}$. This effect appears to be specific for MsrA over-expression since multiple cell lines created from separately prepared viral stocks resulted in similar protection against $\mathrm{H}_{2} \mathrm{O}_{2}$ induced stress. In addition, positive control cells created using a non-MsrA over-expressing virus exhibited nearly identical responses to $\mathrm{H}_{2} \mathrm{O}_{2}$ exposure as untransduced control cells.

The concentrations of $\mathrm{H}_{2} \mathrm{O}_{2}$ used in these experiments were chosen based on the results of a $\mathrm{H}_{2} \mathrm{O}_{2}$ kill curve using control lens cells. Indeed, no decreases in cell viability were observed at concentrations under $750 \mu \mathrm{M}$ and complete cell death was not observed until $\mathrm{H}_{2} \mathrm{O}_{2}$ concentrations reached upwards of $1 \mathrm{mM}$. The concentrations of $\mathrm{H}_{2} \mathrm{O}_{2}$ used in this study to induce cell death fall well within the range of concentrations used in many other studies examining $\mathrm{H}_{2} \mathrm{O}_{2}$-induced cell death in multiple cell types including human lens epithelial cells (Paron et al 2003), human retinal pigmented epithelial cells (Matsui et al 2001) and human neuroblastoma cells (Ruffels et al 2004).

In addition to the protective effects that over-expression of MsrA confers to cells in the presence of oxidative stress, deletion of the MsrA gene in E. coli and yeast renders them more sensitive to oxidative stress conditions. Similar effects are observed in mammals as MsrA deficient mice exhibit a decrease in lifespan of 10\% under standard conditions and upwards of 50\% under hyperoxic conditions (Moskovitz, Bar-Noy, Williams, Requena, Berlett, and Stadtman 2001). The present work demonstrates that decreased levels of MsrA, through siRNA mediated gene silencing, in human lens epithelial cells results in an approximately $25 \%$ increase in $\mathrm{H}_{2} \mathrm{O}_{2}$ sensitivity over $\mathrm{H}_{2} \mathrm{O}_{2}$ concentrations ranging from $570 \mu \mathrm{M}$ to $720 \mu \mathrm{M}$. The data also indicate that the 
transfection process has negative effects on cell viability when compared to untransfected control cells. However, multiple, separately conducted transfections, resulted in nearly identical responses of the cells to $\mathrm{H}_{2} \mathrm{O}_{2}$ and statistical analysis of each replicate produced the same differences in viability between mock and siRNA transfected cells. In addition, cells transfected with a siRNA that is ineffective in decreasing the levels of MsrA exhibited the same responses to $\mathrm{H}_{2} \mathrm{O}_{2}$ as the mock transfected cells. Taken together, the data indicate that the observed differences in cell viability are attributed to decreased levels of MsrA and are not the result of non-specific effects caused by the presence of double-stranded RNA molecules or the transfection process.

$\mathrm{H}_{2} \mathrm{O}_{2}$ is produced at a relatively high rate in cells as a byproduct of aerobic metabolism (Boveris and Chance 1973) and is known to induce cellular damage through the depletion of ATP, GSH and NADPH levels, by the generation of hydroxyl radicals through Fenton reactions (Henle and Linn 1997; Michiels et al 1994) and through DNA strand breakage (Dringen and Hamprecht 1997). Mitochondria are a main target for reactive oxygen species damage and $\mathrm{H}_{2} \mathrm{O}_{2}$ is known to induce a mitochondrial permeability transition and disrupt the mitochondrial membrane potential resulting in the release of cytochrome $\mathrm{C}$ into the cytosol thereby triggering cells to undergo apoptosis through the activation of caspase 3 (Tada-Oikawa et al 1999). MsrA is reported to consist of a cytosolic and mitochondrial form (Hansel et al 2002; Vougier et al 2003). Since the cell viability assays used in the present study measure mitochondrial activity and since loss of cell viability was observed even in the absence of oxidative stress, it is possible that MsrA protects mitochondria in HLEs.

The present studies establish a potential role for MsrA in defense of lens cells against oxidative stress. These data, in conjunction with increased methionine sulfoxide 
content in the human lens with age and upon cataract formation, provide evidence that MsrA is likely to play a major role in cataract formation. Although the targets for MsrA action in the lens have yet to be defined, it has been shown that oxidation of $\alpha$-crystallin results in loss of chaperone activity (Cherian and Abraham 1995; Smith et al 1997b) and that deletion of $\alpha$ A-crystallin results in cataract formation (Brady et al 1997c). Another likely target for MsrA repair are the $\gamma$-crystallins which are rich in methionine residues and are one of the first lens proteins to aggregate in cataract (Phelps Brown 1996). The role of MsrA in the lens is also likely to depend on the state of the reducing system and indeed NADPH levels decrease rapidly upon cataract formation in rats (Lee et al 1985). Future studies will examine the direct targets of MsrA in the lens, the role of the MsrA reducing system, and importantly, will establish a direct relationship between MsrA activity, methionine oxidation and cataract development. 


\section{Chapter VIII}

\section{SUMMARY}

The work that I have been involved with over the last four years, and as is presented in this document, has identified more than 1300 genes whose expression is altered between cataractous and clear human lenses, has demonstrated that numerous gene expression changes occur in the lens with age, has determined that the changes in gene expression that occur in cataracts are not likely to be an artifact of aging, has demonstrated that different isoforms of metallothioneins respond to the presence of metals in human lens epithelial cells in different ways, has indicated that the $\alpha \mathrm{A}-$ crystallin gene can be induced by an exogenous stress, has surveyed the metal content of clear human lenses, has revealed the expression pattern of MsrA in the human lens, has indicated that MsrA is capable of protecting lens epithelial cells against oxidative stress and has implicated a role for MsrA in normal lens cell function even in the absence of stress.

Specifically, RT-PCR differential display identified decreased expression of ribosomal protein L21 in cataract relative to clear lenses. Additional ribosomal protein subunits were also identified to exhibit decreased expression in cataracts relative to clear lenses including L15, L13a and L7a indicating that changes in protein synthesis and/or other pathways mediated by ribosomal proteins may play important roles in lens transparency.

Oligonucleotide microarray hybridization studies demonstrated that the expression levels of more than 1300 genes are altered in lens epithelia isolated from 
human cataracts compared to clear lenses at the 2 -fold or greater level. Of these, 74 were increased and 241 were decreased at the 5 -fold or greater level between cataracts and clear lenses. These data identify multiple novel differences in gene expression between cataracts and clear lenses and functional clustering of the identified genes indicates that alterations in numerous biological pathways are associated with this disease including protein synthesis, oxidative stress, membrane transport, structural proteins, chaperones, cell cycle control proteins and transcriptional control genes. Many of the processes represent metabolic systems designed to preserve lens homeostasis and their altered expression may reflect an inability of the lens to maintain its internal environment in the presence of stress leading to cataract formation. Increases in transcriptional control genes may represent attempts by the lens to compensate for stresses related to cataract.

The data also demonstrate that numerous changes in gene expression in the lens are associated with the aging process; however, these alterations are not the same as those identified in cataracts. Indeed, of the more than 1300 genes altered in cataract and the more than 700 genes altered with age in the lens, only 3 exhibit similar trends in expression between cataractous and aging human lenses. Interestingly, functional clustering of the identified gene expression changes in the lens with age indicate that the majority of biological processes increased with age are actually decreased in cataract, and those that are decreased with age are actually increased in cataract. These data suggest that the identified changes in gene expression in human cataracts are likely cataract specific and are not an artifact of the aging process.

Previous studies suggest that numerous metals are associated with cataract (Cuthbert 1998; Girelli, Corrocher, Bisceglia, Olivieri, De Franceschi, Zelante, and Gasparini 1995; Phelps Brown 1996; Ramakrishnan, Sulochana, Selvaraj, Abdul, 
Lakshmi, and Arunagiri 1995) and increased cadmium levels have been detected in cataract relative to clear lenses (Ramakrishnan, Sulochana, Selvaraj, Abdul, Lakshmi, and Arunagiri 1995) and this work demonstrates that 5 metallothionein genes and 3 chaperones/small heat shock genes, including $\alpha$ A-crystallin, are differentially induced by specific metals in human lens epithelial cells. This is the first demonstration of $\alpha \mathrm{A}-$ crystallin induction by metals or other stresses indicating that $\alpha \mathrm{A}-$ crystallin could be a stress-responsive gene that protects lens cells against metal associated damage. No differences were detected in the levels of 12 metals between young, middle-aged and old clear human lenses with the exception of iron which exhibited decreased levels in old lenses. Theses data provide evidence that metallothioneins and chaperones/small heat shock genes respond to the presence of metals in lens epithelial cells indicating that they may be capable of protecting lens cells against the toxic effects of heavy metals.

One major modification of lens components that persists in cataracts is oxidation of protein methionine residues (Garner and Spector 1980). Oxidized methionines can be reduced to restore normal protein function by a class of enzymes known as the methionine sulfoxide reductases (Weissbach, Etienne, Hoshi, Heinemann, Lowther, Matthews, St John, Nathan, and Brot 2002). The present data demonstrate that MsrA is expressed throughout the human lens, is capable of directly protecting lens epithelial cells against oxidative stress and is necessary for normal lens cell function. These data, in conjunction with increased methionine sulfoxide content in the human lens upon cataract formation, provide evidence that MsrA is likely to play a major role in cataract formation. Age-related cataract is a multifactorial disease with a poorly understood etiology and has been linked to many interrelated environmental, physiological and genetic components and it is therefore unlikely that any one study will identify a comprehensive 
therapy for this disease. However, age-related cataract is of tremendous importance as it is the leading cause of world blindness (Congdon et al 2003), is the most commonly performed surgical procedure in people over 65 and is the leading cause of morbidity and functional impairment in the elderly. Currently, surgery is the only known treatment and accounts for approximately $12 \%$ of the entire Medicare budget (Stark et al 1989). With an aging population, cataract is, and will continue to be, a major economic and quality of life concern, however, it has been estimated that a 10 year delay in the onset of cataract formation would halve the number of people requiring cataract surgery in their lifetime, dramatically increase the quality of life and significantly decrease the cost of health care (Kupfer 1994).

The results of the present studies have advanced our understanding of human cataract by establishing the groundwork of the molecular events surrounding this disease, identifying specific genes induced by the presence of metals in lens epithelial cells that are likely to protect against the toxic effects of heavy metal insult and through establishing a potential role for MsrA in defense of lens cells against oxidative stress through repair of oxidized methionine residues. This work has identified a multitude of genes and their associated pathways that are altered in cataract and are therefore likely to be important for cataract formation. The identification of multiple genes, their associated pathways and specific functions in the lens provide the basis for the molecular events associated with the presence of cataract and point to multiple targets for the development of therapeutic treatments to delay and/or prevent the onset of this disease. 


\section{References}

Amasheh,S., Meiri,N., Gitter,A.H., Schoneberg,T., Mankertz,J., Schulzke,J.D., Fromm,M., 2002. Claudin-2 expression induces cation-selective channels in tight junctions of epithelial cells. J. Cell Sci. 115, 4969-4976.

Andley,U.P., Patel,H.C., Xi,J.H., 2002. The R116C mutation in alpha A-crystallin diminishes its protective ability against stress-induced lens epithelial cell apoptosis. J. Biol. Chem. 277, 10178-10186.

Andley,U.P., Song,Z., Wawrousek,E.F., Bassnett,S., 1998. The molecular chaperone alphaA-crystallin enhances lens epithelial cell growth and resistance to UVA stress. J. Biol. Chem. 273, 31252-31261.

Andley,U.P., Song,Z., Wawrousek,E.F., Fleming,T.P., Bassnett,S., 2000. Differential protective activity of alpha A- and alphaB-crystallin in lens epithelial cells. J. Biol. Chem. 275, 36823-36831.

Andley,U.P., Walsh,A., Kochevar,I.E., Reddan,J.R., 1990. Effect of ultraviolet-B radiation on protein synthesis in cultured lens epithelial cells. Curr. Eye Res. 9, 1099-1106.

Angel,P., Poting,A., Mallick,U., Rahmsdorf,H.J., Schorpp,M., Herrlich,P., 1986. Induction of metallothionein and other mRNA species by carcinogens and tumor promoters in primary human skin fibroblasts. Mol. Cell Biol. 6, 1760-1766.

Arita,T., Lin,L.R., Reddy,V.N., 1988. Differentiation of human lens epithelial cells in tissue culture. Exp. Eye Res. 47, 905-910.

Artic Monitoring and Assessment Program (AMAP). Heavy metals. 2000. http://www.amap.no/assess/soaer7.htm/, AMAP Report of Issues of Concern. Oslo, Norway: AMAP.

Ausubel I,F.M. Current Protocols in Molecular Biology. 2. 1998. John Wiley and Sons, Inc.

Bassnett,S., Kuszak,J.R., Reinisch,L., Brown,H.G., Beebe,D.C., 1994. Intercellular communication between epithelial and fiber cells of the eye lens. J. Cell Sci. 107 ( Pt 4), 799-811.

Bauman,J.W., Liu,J., Liu,Y.P., Klaassen,C.D., 1991. Increase in metallothionein produced by chemicals that induce oxidative stress. Toxicol. Appl. Pharmacol. $110,347-354$.

Beatty,S., Koh,H., Phil,M., Henson,D., Boulton,M., 2000. The role of oxidative stress in the pathogenesis of age-related macular degeneration. Surv. Ophthalmol. 45, 115134. 
Behndig,A., Karlsson,K., Reaume,A.G., Sentman,M.L., Marklund,S.L., 2001. In vitro photochemical cataract in mice lacking copper-zinc superoxide dismutase. Free Radic. Biol. Med. 31, 738-744.

Ben Ishai,R., Scharf,R., Sharon,R., Kapten,I., 1990. A human cellular sequence implicated in trk oncogene activation is DNA damage inducible. Proc. Natl. Acad. Sci. U. S. A 87, 6039-6043.

Berghofer-Hochheimer,Y., Zurek,C., Wolfl,S., Hemmerich,P., Munder,T., 1998. L7 protein is a coregulator of vitamin $\mathrm{D}$ receptor-retinoid $\mathrm{X}$ receptor-mediated transactivation. J. Cell Biochem. 69, 1-12.

Bevort,M., Leffers,H., 2000. Down regulation of ribosomal protein mRNAs during neuronal differentiation of human NTERA2 cells. Differentiation 66, 81-92.

Blalock,E.M., Chen,K.C., Sharrow,K., Herman,J.P., Porter,N.M., Foster,T.C., Landfield,P.W., 2003. Gene microarrays in hippocampal aging: statistical profiling identifies novel processes correlated with cognitive impairment. J. Neurosci. 23, 3807-3819.

Bloemendal H. Lens Proteins. In: Bloemendal H, editor. Molecular and cellular biology of the eye lens. 1-47. 1981. New York: Wiley.

Bodaness,R.S., Leclair,M., Zigler,J.S., Jr., 1984. An analysis of the H2O2-mediated crosslinking of lens crystallins catalyzed by the heme-undecapeptide from cytochrome c. Arch. Biochem. Biophys. 231, 461-469.

Bonanno,J.A., 1991. Regulation of corneal epithelial intracellular pH. Optom. Vis. Sci. $68,682-686$.

Borchman,D., Paterson,C.A., Delamere,N.A., 1989. Oxidative inhibition of Ca2+ATPase in the rabbit lens. Invest Ophthalmol. Vis. Sci. 30, 1633-1637.

Borkman,R.F., 1984. Cataracts and photochemical damage in the lens. Ciba Found. Symp. 106, 88-109.

Boveris,A., Chance,B., 1973. The mitochondrial generation of hydrogen peroxide. General properties and effect of hyperbaric oxygen. Biochem. J. 134, 707-716.

Brady,J.P., Garland,D., Duglas-Tabor,Y., Robison,W.G., Jr., Groome,A., Wawrousek,E.F., 1997. Targeted disruption of the mouse alpha A-crystallin gene induces cataract and cytoplasmic inclusion bodies containing the small heat shock protein alpha B-crystallin. Proc. Natl. Acad. Sci. U. S. A 94, 884-889.

Brot,N., Weissbach,L., Werth,J., Weissbach,H., 1981. Enzymatic reduction of proteinbound methionine sulfoxide. Proc. Natl. Acad. Sci. U. S. A 78, 2155-2158.

Burnatowska-Hledin,M., Zhao,P., Capps,B., Poel,A., Parmelee,K., Mungall,C., Sharangpani,A., Listenberger,L., 2000. VACM-1, a cullin gene family member, regulates cellular signaling. Am. J. Physiol Cell Physiol 279, C266-C273. 
Caldwell,P., Luk,D.C., Weissbach,H., Brot,N., 1978. Oxidation of the methionine residues of Escherichia coli ribosomal protein L12 decreases the protein's biological activity. Proc. Natl. Acad. Sci. U. S. A 75, 5349-5352.

Carney,J.P., Maser,R.S., Olivares,H., Davis,E.M., Le Beau,M., Yates,J.R., III, Hays,L., Morgan,W.F., Petrini,J.H., 1998. The hMre11/hRad50 protein complex and Nijmegen breakage syndrome: linkage of double-strand break repair to the cellular DNA damage response. Cell 93, 477-486.

Chen,E., Proestou,G., Bourbeau,D., Wang,E., 2000. Rapid up-regulation of peptide elongation factor EF-1alpha protein levels is an immediate early event during oxidative stress-induced apoptosis. Exp. Cell Res. 259, 140-148.

Cherian,M., Abraham,E.C., 1995. Decreased molecular chaperone property of alphacrystallins due to posttranslational modifications. Biochem. Biophys. Res. Commun. 208, 675-679.

Chester,K.A., Robson,L., Begent,R.H., Talbot,I.C., Pringle,J.H., Primrose,L., Macpherson,A.J., Boxer,G., Southall,P., Malcolm,A.D., 1989. Identification of a human ribosomal protein mRNA with increased expression in colorectal tumours. Biochim. Biophys. Acta 1009, 297-300.

Ciorba,M.A., Heinemann,S.H., Weissbach,H., Brot,N., Hoshi,T., 1997. Modulation of potassium channel function by methionine oxidation and reduction. Proc. Natl. Acad. Sci. U. S. A 94, 9932-9937.

Clayton,R.M., Cuthbert,J., Seth,J., Phillips,C.I., Bartholomew,R.S., Reid,J.M., 1984. Epidemiological and other studies in the assessment of factors contributing to cataractogenesis. Ciba Found. Symp. 106, 25-47.

Cobb,B.A., Petrash,J.M., 2000. Structural and functional changes in the alpha Acrystallin R116C mutant in hereditary cataracts. Biochemistry 39, 15791-15798.

Congdon,N.G., Friedman,D.S., Lietman,T., 2003. Important causes of visual impairment in the world today. JAMA 290, 2057-2060.

Creutz,C.E., Tomsig,J.L., Snyder,S.L., Gautier,M.C., Skouri,F., Beisson,J., Cohen,J., 1998. The copines, a novel class of C2 domain-containing, calcium-dependent, phospholipid-binding proteins conserved from Paramecium to humans. J. Biol. Chem. 273, 1393-1402.

Cuthbert,J.A., 1998. Wilson's disease. Update of a systemic disorder with protean manifestations. Gastroenterol. Clin. North Am. 27, 655-vii.

Dasgupta,S., Hohman,T.C., Carper,D., 1992. Hypertonic stress induces alpha B-crystallin expression. Exp. Eye Res. 54, 461-470.

Delaye,M., Tardieu,A., 1983. Short-range order of crystallin proteins accounts for eye lens transparency. Nature 302, 415-417. 
Deuel,T.F., Zhang,N., Yeh,H.J., Silos-Santiago,I., Wang,Z.Y., 2002. Pleiotrophin: a cytokine with diverse functions and a novel signaling pathway. Arch. Biochem. Biophys. 397, 162-171.

Dringen,R., Hamprecht,B., 1997. Involvement of glutathione peroxidase and catalase in the disposal of exogenous hydrogen peroxide by cultured astroglial cells. Brain Res. 759, 67-75.

Duncan,G., Jacob,T.J., 1984. Calcium and the physiology of cataract. Ciba Found. Symp. $106,132-152$.

Duncan,G., Marcantonio,J.M., 1982. Changes in lens amino acid transport and protein metabolism during osmotic cataract produced by ouabain. Trans. Ophthalmol. Soc. U. K. 102 Pt 3, 314-317.

Fath,M., VanderNoot,V., Kilpelainen,I., Kinnunen,T., Rauvala,H., Linhardt,R.J., 1999. Interaction of soluble and surface-bound heparin binding growth-associated molecule with heparin. FEBS Lett. 454, 105-108.

Ferreira PA,P.W. Characterization of vertebrate homologs of Drosophila photoreceptor proteins. In: Anderson RE, LaVail MM, Holyfield JG, editors. Degenerative diseases of the retina. 263-274. 1995. New York: Plenum Press.

Ferreira,P.A., Hom,J.T., Pak,W.L., 1995. Retina-specifically expressed novel subtypes of bovine cyclophilin. J. Biol. Chem. 270, 23179-23188.

Fisher,R.F., 1969. The significance of the shape of the lens and capsular energy changes in accommodation. J. Physiol 201, 21-47.

Fornace,A.J., Jr., Schalch,H., Alamo,I., Jr., 1988. Coordinate induction of metallothioneins I and II in rodent cells by UV irradiation. Mol. Cell Biol. 8, 4716-4720.

Foster,R., Jahroudi,N., Varshney,U., Gedamu,L., 1988. Structure and expression of the human metallothionein-IG gene. Differential promoter activity of two linked metallothionein-I genes in response to heavy metals. J. Biol. Chem. 263, 1152811535 .

Frasca,D., Nguyen,D., Riley,R.L., Blomberg,B.B., 2003. Effects of aging on proliferation and E47 transcription factor activity induced by different stimuli in murine splenic B cells. Mech. Ageing Dev. 124, 361-369.

Frederikse PH,P.J. Novel and heat inducible binding of HSF to alpha-crystallin regulatory sequences [ARVO Abstract]. 1994. Investigative Ophthalmology and Visual Science; 35:2073. Abstract nr 3792.

Frederikse,P.H., Farnsworth,P., Zigler,J.S., Jr., 1999. Thiamine deficiency in vivo produces fiber cell degeneration in mouse lenses. Biochem. Biophys. Res. Commun. 258, 703-707. 
Freskgard,P.O., Bergenhem,N., Jonsson,B.H., Svensson,M., Carlsson,U., 1992. Isomerase and chaperone activity of prolyl isomerase in the folding of carbonic anhydrase. Science 258, 466-468.

Frigerio,J.M., Berthezene,P., Garrido,P., Ortiz,E., Barthellemy,S., Vasseur,S., Sastre,B., Seleznieff,I., Dagorn,J.C., Iovanna,J.L., 1995. Analysis of 2166 clones from a human colorectal cancer cDNA library by partial sequencing. Hum. Mol. Genet. 4, 37-43.

Fukagawa,N.K., Timblin,C.R., Buder-Hoffman,S., Mossman,B.T., 2000. Strategies for evaluation of signaling pathways and transcription factors altered in aging. Antioxid. Redox. Signal. 2, 379-389.

Ganea,E., 2001. Chaperone-like activity of alpha-crystallin and other small heat shock proteins. Curr. Protein Pept. Sci. 2, 205-225.

Garadi,R., Foltyn,A.R., Giblin,F.J., Reddy,V.N., 1984. Protein synthesis in x-irradiated rabbit lens. Invest Ophthalmol. Vis. Sci. 25, 147-152.

Garner,M.H., Spector,A., 1980. Selective oxidation of cysteine and methionine in normal and senile cataractous lenses. Proc. Natl. Acad. Sci. U. S. A 77, 1274-1277.

Garnovskaya,M.N., Mukhin,Y.V., Vlasova,T.M., Raymond,J.R., 2003. Hypertonicity activates $\mathrm{Na}+/ \mathrm{H}+$ exchange through Janus kinase 2 and calmodulin. J. Biol. Chem. 278, 16908-16915.

Ghiselli,G., Siracusa,L.D., Iozzo,R.V., 1999. Complete cDNA cloning, genomic organization, chromosomal assignment, functional characterization of the promoter, and expression of the murine Bamacan gene. J. Biol. Chem. 274, 17384-17393.

Giblin,F.J., 2000. Glutathione: a vital lens antioxidant. J. Ocul. Pharmacol. Ther. 16, 121135.

Gilligan,D.M., Sarid,R., Weese,J., 2002. Adducin in platelets: activation-induced phosphorylation by PKC and proteolysis by calpain. Blood 99, 2418-2426.

Gilmour,D.T., Lyon,G.J., Carlton,M.B., Sanes,J.R., Cunningham,J.M., Anderson,J.R., Hogan,B.L., Evans,M.J., Colledge,W.H., 1998. Mice deficient for the secreted glycoprotein SPARC/osteonectin/BM40 develop normally but show severe ageonset cataract formation and disruption of the lens. EMBO J. 17, 1860-1870.

Girelli,D., Corrocher,R., Bisceglia,L., Olivieri,O., De Franceschi,L., Zelante,L., Gasparini,P., 1995. Molecular basis for the recently described hereditary hyperferritinemia-cataract syndrome: a mutation in the iron-responsive element of ferritin L-subunit gene (the "Verona mutation"). Blood 86, 4050-4053.

Goldstone,S.D., Lavin,M.F., 1993. Isolation of a cDNA clone, encoding the ribosomal protein S20, downregulated during the onset of apoptosis in a human leukaemic cell line. Biochem. Biophys. Res. Commun. 196, 619-623. 
Gonzalez-Mariscal,L., Betanzos,A., Nava,P., Jaramillo,B.E., 2003. Tight junction proteins. Prog. Biophys. Mol. Biol. 81, 1-44.

Goodenough,D.A., Dick,J.S., Lyons,J.E., 1980. Lens metabolic cooperation: a study of mouse lens transport and permeability visualized with freeze-substitution autoradiography and electron microscopy. J. Cell Biol. 86, 576-589.

Gorlich,D., Kutay,U., 1999. Transport between the cell nucleus and the cytoplasm. Annu. Rev. Cell Dev. Biol. 15, 607-660.

Goswami,S., Sheets,N.L., Zavadil,J., Chauhan,B.K., Bottinger,E.P., Reddy,V.N., Kantorow,M., Cvekl,A., 2003. Spectrum and range of oxidative stress responses of human lens epithelial cells to $\mathrm{H} 2 \mathrm{O} 2$ insult. Invest Ophthalmol. Vis. Sci. 44, 2084-2093.

Gounari,F., Karagianni,N., Mincheva,A., Lichter,P., Georgatos,S.D., Schirrmacher,V., 1997. The mouse filensin gene: structure and evolutionary relation to other intermediate filament genes. FEBS Lett. 413, 371-378.

Grabowski,D.T., Deutsch,W.A., Derda,D., Kelley,M.R., 1991. Drosophila AP3, a presumptive DNA repair protein, is homologous to human ribosomal associated protein P0. Nucleic Acids Res. 19, 4297.

Graw,J., Loster,J., Soewarto,D., Fuchs,H., Reis,A., Wolf,E., Balling,R., Hrabe,d.A., 2001. Aey2, a new mutation in the betaB2-crystallin-encoding gene of the mouse. Invest Ophthalmol. Vis. Sci. 42, 1574-1580.

Grubb,B.R., DuVal,G.E., Morris,J.S., Bentley,P.J., 1985. Accumulation of cadmium by the eye with special reference to the lens. Toxicol. Appl. Pharmacol. 77, 444-450.

Gunes,C., Heuchel,R., Georgiev,O., Muller,K.H., Lichtlen,P., Bluthmann,H., Marino,S., Aguzzi,A., Schaffner,W., 1998. Embryonic lethality and liver degeneration in mice lacking the metal-responsive transcriptional activator MTF-1. EMBO J. 17, 2846-2854.

Haloui,Z., Pujol,J.P., Galera,P., Courtois,Y., Laurent,M., 1990. Analysis of lens protein synthesis in a cataractous mutant mouse: the Cat Fraser. Exp. Eye Res. 51, 487494.

Hansel,A., Kuschel,L., Hehl,S., Lemke,C., Agricola,H.J., Hoshi,T., Heinemann,S.H., 2002. Mitochondrial targeting of the human peptide methionine sulfoxide reductase (MSRA), an enzyme involved in the repair of oxidized proteins. FASEB J. 16, 911-913.

Harding JJ,C.MJ. The Lens: development, proteins, metabolism and cataract. The Eye Davson H.(Ed.) 1B. 1984. Orlando, FL. U.S.A., Academic Press.

Harding,J.J., Blakytny,R., Ganea,E., 1996. Glutathione in disease. Biochem. Soc. Trans. 24, 881-884. 
Haslbeck,M., 2002. sHsps and their role in the chaperone network. Cell Mol. Life Sci. 59, 1649-1657.

Hawse,J.R., Hejtmancik,J.F., Huang,Q., Sheets,N.L., Hosack,D.A., Lempicki,R.A., Horwitz,J., Kantorow,M., 2003. Identification and functional clustering of global gene expression differences between human age-related cataract and clear lenses. Mol. Vis. 9, 515-537.

Head,M.W., Hurwitz,L., Goldman,J.E., 1996. Transcription regulation of alpha Bcrystallin in astrocytes: analysis of HSF and AP1 activation by different types of physiological stress. J. Cell Sci. 109 ( Pt 5), 1029-1039.

Heiss,N.S., Girod,A., Salowsky,R., Wiemann,S., Pepperkok,R., Poustka,A., 1999. Dyskerin localizes to the nucleolus and its mislocalization is unlikely to play a role in the pathogenesis of dyskeratosis congenita. Hum. Mol. Genet. 8, 25152524.

Henle,E.S., Linn,S., 1997. Formation, prevention, and repair of DNA damage by iron/hydrogen peroxide. J. Biol. Chem. 272, 19095-19098.

Hess,J.F., Casselman,J.T., Kong,A.P., FitzGerald,P.G., 1998. Primary sequence, secondary structure, gene structure, and assembly properties suggests that the lens-specific cytoskeletal protein filensin represents a novel class of intermediate filament protein. Exp. Eye Res. 66, 625-644.

Heuchel,R., Radtke,F., Georgiev,O., Stark,G., Aguet,M., Schaffner,W., 1994. The transcription factor MTF-1 is essential for basal and heavy metal-induced metallothionein gene expression. EMBO J. 13, 2870-2875.

Hightower,K.R., 1994. A review of the evidence that ultraviolet irradiation is a risk factor in cataractogenesis. Doc. Ophthalmol. 88, 205-220.

Hightower,K.R., 1995. The role of the lens epithelium in development of UV cataract. Curr. Eye Res. 14, 71-78.

Horwitz,J., 1992. Alpha-crystallin can function as a molecular chaperone. Proc. Natl. Acad. Sci. U. S. A 89, 10449-10453.

Ibaraki,N., Chen,S.C., Lin,L.R., Okamoto,H., Pipas,J.M., Reddy,V.N., 1998. Human lens epithelial cell line. Exp. Eye Res. 67, 577-585.

Ikebe,H., Susan,S.R., Giblin,F.J., Reddan,J.R., Reddy,V.N., 1989. Effect of inhibition of the glutathione redox cycle on the ultrastructure of peroxide-treated rabbit epithelial cells. Exp. Eye Res. 48, 421-432.

Inaguma,Y., Hasegawa,K., Goto,S., Ito,H., Kato,K., 1995. Induction of the synthesis of hsp27 and alpha B crystallin in tissues of heat-stressed rats and its suppression by ethanol or an alpha 1-adrenergic antagonist. J. Biochem. (Tokyo) 117, 1238-1243. 
Inaguma,Y., Shinohara,H., Goto,S., Kato,K., 1992. Translocation and induction of alpha B crystallin by heat shock in rat glioma (GA-1) cells. Biochem. Biophys. Res. Commun. 182, 844-850.

Iwaki,A., Iwaki,T., Goldman,J.E., Liem,R.K., 1990. Multiple mRNAs of rat brain alphacrystallin B chain result from alternative transcriptional initiation. J. Biol. Chem. 265, 22197-22203.

Iwaki,A., Nagano,T., Nakagawa,M., Iwaki,T., Fukumaki,Y., 1997. Identification and characterization of the gene encoding a new member of the alpha-crystallin/small hsp family, closely linked to the alphaB-crystallin gene in a head-to-head manner. Genomics 45, 386-394.

Iwano,T., Tachibana,M., Reth,M., Shinkai,Y., 2004. Importance of TRF1 for functional telomere structure. J. Biol. Chem. 279, 1442-1448.

Jeong,D., Kim,T.S., Chung,Y.W., Lee,B.J., Kim,I.Y., 2002. Selenoprotein W is a glutathione-dependent antioxidant in vivo. FEBS Lett. 517, 225-228.

Johnson,D., Travis,J., 1979. The oxidative inactivation of human alpha-1-proteinase inhibitor. Further evidence for methionine at the reactive center. J. Biol. Chem. 254, 4022-4026.

Jones JB Jr,C.V. Sampling, handling and analyzing plant tissue samples. In: Westerman RL, ed. Soil Testing and Plant Analysis. 3rd, 389-426. 1999. Soil Science Society of America; Madison, WI.

Kagi,J.H., Schaffer,A., 1988. Biochemistry of metallothionein. Biochemistry 27, 85098515.

Kaida,T., Kozawa,O., Ito,T., Tanabe,K., Ito,H., Matsuno,H., Niwa,M., Miyata,H., Uematsu,T., Kato,K., 1999. Vasopressin stimulates the induction of heat shock protein 27 and alphaB-crystallin via protein kinase $C$ activation in vascular smooth muscle cells. Exp. Cell Res. 246, 327-337.

Kampmeier,J., Behrens,A., Wang,Y., Yee,A., Anderson,W.F., Hall,F.L., Gordon,E.M., McDonnell,P.J., 2000. Inhibition of rabbit keratocyte and human fetal lens epithelial cell proliferation by retrovirus-mediated transfer of antisense cyclin G1 and antisense MAT1 constructs. Hum. Gene Ther. 11, 1-8.

Kantorow,M., Horwitz,J., Carper,D., 1998a. Up-regulation of osteonectin/SPARC in agerelated cataractous human lens epithelia. Mol. Vis. 4, 17.

Kantorow,M., Huang,Q., Yang,X.J., Sage,E.H., Magabo,K.S., Miller,K.M., Horwitz,J., 2000. Increased expression of osteonectin/SPARC mRNA and protein in agerelated human cataracts and spatial expression in the normal human lens. Mol. Vis. 6, 24-29. 
Kantorow,M., Kays,T., Horwitz,J., Huang,Q., Sun,J., Piatigorsky,J., Carper,D., 1998 b. Differential display detects altered gene expression between cataractous and normal human lenses. Invest Ophthalmol. Vis. Sci. 39, 2344-2354.

Karin,M., Haslinger,A., Holtgreve,H., Richards,R.I., Krauter,P., Westphal,H.M., Beato,M., 1984. Characterization of DNA sequences through which cadmium and glucocorticoid hormones induce human metallothionein-IIA gene. Nature 308, 513-519.

Kelly,E.J., Quaife,C.J., Froelick,G.J., Palmiter,R.D., 1996. Metallothionein I and II protect against zinc deficiency and zinc toxicity in mice. J. Nutr. 126, 1782-1790.

Kim,J., Chubatsu,L.S., Admon,A., Stahl,J., Fellous,R., Linn,S., 1995. Implication of mammalian ribosomal protein $\mathrm{S} 3$ in the processing of DNA damage. J. Biol. Chem. 270, 13620-13629.

Kuck,J.F., 1990. Late onset hereditary cataract of the emory mouse. A model for human senile cataract. Exp. Eye Res. 50, 659-664.

Kuhlman,P.A., Hughes,C.A., Bennett,V., Fowler,V.M., 1996. A new function for adducin. Calcium/calmodulin-regulated capping of the barbed ends of actin filaments. J. Biol. Chem. 271, 7986-7991.

Kupfer,C.U.B.G.T. Leading causes of visual impairment word wide. Principles and Practice of Ophthalmology Basic Science, 1249-1255. 1994. Philadelphia, W.B. Saunders Co.

Kuwabara,T., 1975. The maturation of the lens cell: a morphologic study. Exp. Eye Res. $20,427-443$.

Laine,R.O., Shay,N.F., Kilberg,M.S., 1994. Nuclear retention of the induced mRNA following amino acid-dependent transcriptional regulation of mammalian ribosomal proteins L17 and S25. J. Biol. Chem. 269, 9693-9697.

Lee,E.H., Seomun,Y., Hwang,K.H., Kim,J.E., Kim,I.S., Kim,J.H., Joo,C.K., 2000. Overexpression of the transforming growth factor-beta-inducible gene betaig-h3 in anterior polar cataracts. Invest Ophthalmol. Vis. Sci. 41, 1840-1845.

Lee,S.M., Schade,S.Z., Doughty,C.C., 1985. Aldose reductase, NADPH and NADP+ in normal, galactose-fed and diabetic rat lens. Biochim. Biophys. Acta 841, 247-253.

Lilie,H., Lang,K., Rudolph,R., Buchner,J., 1993. Prolyl isomerases catalyze antibody folding in vitro. Protein Sci. 2, 1490-1496.

Lim,J.M., Lee,J.H., Wee,W.R., Joo,C.K., 2002. Downregulated expression of ADAM9 in anterior polar cataracts. J. Cataract Refract. Surg. 28, 697-702.

Lin,L.R., Carper,D., Yokoyama,T., Reddy,V.N., 1993. The effect of hypertonicity on aldose reductase, alpha B-crystallin, and organic osmolytes in the retinal pigment epithelium. Invest Ophthalmol. Vis. Sci. 34, 2352-2359. 
Litt,M., Kramer,P., LaMorticella,D.M., Murphey,W., Lovrien,E.W., Weleber,R.G., 1998. Autosomal dominant congenital cataract associated with a missense mutation in the human alpha crystallin gene CRYAA. Hum. Mol. Genet. 7, 471-474.

Liu,J., Liu,Y., Michalska,A.E., Choo,K.H., Klaassen,C.D., 1996. Metallothionein plays less of a protective role in cadmium-metallothionein-induced nephrotoxicity than in cadmium chloride-induced hepatotoxicity. J. Pharmacol. Exp. Ther. 276, 12161223.

Lu,H., Hunt,D.M., Ganti,R., Davis,A., Dutt,K., Alam,J., Hunt,R.C., 2002. Metallothionein protects retinal pigment epithelial cells against apoptosis and oxidative stress. Exp. Eye Res. 74, 83-92.

Mackay,D.S., Boskovska,O.B., Knopf,H.L., Lampi,K.J., Shiels,A., 2002. A nonsense mutation in CRYBB1 associated with autosomal dominant cataract linked to human chromosome 22q. Am. J. Hum. Genet. 71, 1216-1221.

Mager,W.H., 1988. Control of ribosomal protein gene expression. Biochim. Biophys. Acta 949, 1-15.

Martin,M.E., Fargion,S., Brissot,P., Pellat,B., Beaumont,C., 1998. A point mutation in the bulge of the iron-responsive element of the $\mathrm{L}$ ferritin gene in two families with the hereditary hyperferritinemia-cataract syndrome. Blood 91, 319-323.

Masters,B.A., Kelly,E.J., Quaife,C.J., Brinster,R.L., Palmiter,R.D., 1994. Targeted disruption of metallothionein I and II genes increases sensitivity to cadmium. Proc. Natl. Acad. Sci. U. S. A 91, 584-588.

Matsui,H., Lin,L.R., Ho,Y.S., Reddy,V.N., 2003. The effect of up- and downregulation of MnSOD enzyme on oxidative stress in human lens epithelial cells. Invest Ophthalmol. Vis. Sci. 44, 3467-3475.

Matsui,H., Lin,L.R., Singh,D.P., Shinohara,T., Reddy,V.N., 2001. Lens epitheliumderived growth factor: increased survival and decreased DNA breakage of human RPE cells induced by oxidative stress. Invest Ophthalmol. Vis. Sci. 42, 29352941.

Mazuruk,K., Schoen,T.J., Chader,G.J., Iwata,T., Rodriguez,I.R., 1996. Structural organization and chromosomal localization of the human ribosomal protein L9 gene. Biochim. Biophys. Acta 1305, 151-162.

McAleer,M.F., Tuan,R.S., 2001. Metallothionein overexpression in human trophoblastic cells protects against cadmium-induced apoptosis. In Vitr. Mol. Toxicol. 14, 2542.

McNamara,M., Augusteyn,R.C., 1984. The effects of hydrogen peroxide on lens proteins: a possible model for nuclear cataract. Exp. Eye Res. 38, 45-56. 
Michalska,A.E., Choo,K.H., 1993. Targeting and germ-line transmission of a null mutation at the metallothionein I and II loci in mouse. Proc. Natl. Acad. Sci. U. S. A $90,8088-8092$.

Michiels,C., Raes,M., Toussaint,O., Remacle,J., 1994. Importance of Se-glutathione peroxidase, catalase, and $\mathrm{Cu} / \mathrm{Zn}-\mathrm{SOD}$ for cell survival against oxidative stress. Free Radic. Biol. Med. 17, 235-248.

Miura,T., Muraoka,S., Ogiso,T., 1997. Antioxidant activity of metallothionein compared with reduced glutathione. Life Sci. 60, L-9.

Moskovitz,J., Bar-Noy,S., Williams,W.M., Requena,J., Berlett,B.S., Stadtman,E.R., 2001. Methionine sulfoxide reductase (MsrA) is a regulator of antioxidant defense and lifespan in mammals. Proc. Natl. Acad. Sci. U. S. A 98, 12920-12925.

Moskovitz,J., Berlett,B.S., Poston,J.M., Stadtman,E.R., 1997. The yeast peptidemethionine sulfoxide reductase functions as an antioxidant in vivo. Proc. Natl. Acad. Sci. U. S. A 94, 9585-9589.

Moskovitz,J., Flescher,E., Berlett,B.S., Azare,J., Poston,J.M., Stadtman,E.R., 1998. Overexpression of peptide-methionine sulfoxide reductase in Saccharomyces cerevisiae and human $\mathrm{T}$ cells provides them with high resistance to oxidative stress. Proc. Natl. Acad. Sci. U. S. A 95, 14071-14075.

Moskovitz,J., Rahman,M.A., Strassman,J., Yancey,S.O., Kushner,S.R., Brot,N., Weissbach,H., 1995. Escherichia coli peptide methionine sulfoxide reductase gene: regulation of expression and role in protecting against oxidative damage. J. Bacteriol. 177, 502-507.

Moskovitz,J., Weissbach,H., Brot,N., 1996. Cloning the expression of a mammalian gene involved in the reduction of methionine sulfoxide residues in proteins. Proc. Natl. Acad. Sci. U. S. A 93, 2095-2099.

Naora,H., Takai,I., Adachi,M., Naora,H., 1998. Altered cellular responses by varying expression of a ribosomal protein gene: sequential coordination of enhancement and suppression of ribosomal protein $\mathrm{S} 3 \mathrm{a}$ gene expression induces apoptosis. J. Cell Biol. 141, 741-753.

Neumann,F., Krawinkel,U., 1997. Constitutive expression of human ribosomal protein L7 arrests the cell cycle in G1 and induces apoptosis in Jurkat T-lymphoma cells. Exp. Cell Res. 230, 252-261.

Oguro,T., Yoshida,T., 2001. Effect of ultraviolet A on ornithine decarboxylase and metallothionein gene expression in mouse skin. Photodermatol. Photoimmunol. Photomed. 17, 71-78.

Oppermann,B., Zhang,W., Magabo,K., Kantorow,M., 2001. Identification and spatial analysis of metallothioneins expressed by the adult human lens. Invest Ophthalmol. Vis. Sci. 42, 188-193. 
Packer,L.a.C.E. Biothiols in health and disease. 1995. Marcel Dekker, Inc: New York, U.S.A.

Park,J.D., Liu,Y., Klaassen,C.D., 2001. Protective effect of metallothionein against the toxicity of cadmium and other metals(1). Toxicology 163, 93-100.

Parmigiani,C.M., McAvoy,J.W., 1991. The roles of laminin and fibronectin in the development of the lens capsule. Curr. Eye Res. 10, 501-511.

Paron,I., D'Elia,A., D'Ambrosio,C., Scaloni,A., D'Aurizio,F., Prescott,A., Damante,G., Tell,G., 2003. A proteomic approach to identify early molecular targets of oxidative stress in human epithelial lens cells. Biochem. J. Pt.

Paterson,C.A., Zeng,J., Husseini,Z., Borchman,D., Delamere,N.A., Garland,D., JimenezAsensio,J., 1997. Calcium ATPase activity and membrane structure in clear and cataractous human lenses. Curr. Eye Res. 16, 333-338.

Phelps Brown,B. Lens Disorders: a clinical manual of cataract diagnosis. 1-135. 1996.

Piatigorsky,J., 1981. Lens differentiation in vertebrates. A review of cellular and molecular features. Differentiation 19, 134-153.

Pitkanen,S., Robinson,B.H., 1996. Mitochondrial complex I deficiency leads to increased production of superoxide radicals and induction of superoxide dismutase. J. Clin. Invest 98, 345-351.

Pras,E., Frydman,M., Levy-Nissenbaum,E., Bakhan,T., Raz,J., Assia,E.I., Goldman,B., Pras,E., 2000. A nonsense mutation (W9X) in CRYAA causes autosomal recessive cataract in an inbred Jewish Persian family. Invest Ophthalmol. Vis. Sci. 41, 3511-3515.

Rae,J.L., Bartling,C., Rae,J., Mathias,R.T., 1996. Dye transfer between cells of the lens. J. Membr. Biol. 150, 89-103.

Rae,J.L., Stacey,T., 1979. Lanthanum and procion yellow as extracellular markers in the crystalline lens of the rat. Exp. Eye Res. 28, 1-21.

Ramakrishnan,S., Sulochana,K.N., Selvaraj,T., Abdul,R.A., Lakshmi,M., Arunagiri,K., 1995. Smoking of beedies and cataract: cadmium and vitamin $\mathrm{C}$ in the lens and blood. Br. J. Ophthalmol. 79, 202-206.

Rassow,J., Pfanner,N., 1996. Protein biogenesis: chaperones for nascent polypeptides. Curr. Biol. 6, 115-118.

Rathbun,W.B., Schmidt,A.J., Holleschau,A.M., 1993. Activity loss of glutathione synthesis enzymes associated with human subcapsular cataract. Invest Ophthalmol. Vis. Sci. 34, 2049-2054. 
Reddan JR. Control of cell division in the ocular lens, retina and vitreous humour. In: Cell biology of the eye. McDevitt DS, editor. 299-375. 1982. New York: Academic Press.

Reddan,J.R., Steiger,C.A., Dziedzic,D.C., Gordon,S.R., 1996. Regional differences in the distribution of catalase in the epithelium of the ocular lens. Cell Mol. Biol. (Noisy. -le-grand) 42, 209-219.

Reddy,V.N., 1971. Metabolism of glutathione in the lens. Exp. Eye Res. 11, 310-328.

Reddy,V.N., Giblin,F.J., Lin,L.R., Dang,L., Unakar,N.J., Musch,D.C., Boyle,D.L., Takemoto,L.J., Ho,Y.S., Knoernschild,T., Juenemann,A., Lutjen-Drecoll,E., 2001. Glutathione peroxidase-1 deficiency leads to increased nuclear light scattering, membrane damage, and cataract formation in gene-knockout mice. Invest Ophthalmol. Vis. Sci. 42, 3247-3255.

Rinfret,A., Collins,C., Menard,R., Anderson,S.K., 1994. The N-terminal cyclophilinhomologous domain of a 150-kilodalton tumor recognition molecule exhibits both peptidylprolyl cis-trans-isomerase and chaperone activities. Biochemistry 33, 1668-1673.

Rosen,P., Nawroth,P.P., King,G., Moller,W., Tritschler,H.J., Packer,L., 2001. The role of oxidative stress in the onset and progression of diabetes and its complications: a summary of a Congress Series sponsored by UNESCO-MCBN, the American Diabetes Association and the German Diabetes Society. Diabetes Metab Res. Rev. 17, 189-212.

Rout,M.P., Aitchison,J.D., 2000. Pore relations: nuclear pore complexes and nucleocytoplasmic exchange. Essays Biochem. 36, 75-88.

Roy,A.K., Oh,T., Rivera,O., Mubiru,J., Song,C.S., Chatterjee,B., 2002. Impacts of transcriptional regulation on aging and senescence. Ageing Res. Rev. 1, 367-380.

Ruan,H., Tang,X.D., Chen,M.L., Joiner,M.L., Sun,G., Brot,N., Weissbach,H., Heinemann,S.H., Iverson,L., Wu,C.F., Hoshi,T., Chen,M.L., Joiner,M.A., Heinemann,S.H., 2002. High-quality life extension by the enzyme peptide methionine sulfoxide reductase. Proc. Natl. Acad. Sci. U. S. A 99, 2748-2753.

Rudd,K.E., Sofia,H.J., Koonin,E.V., Plunkett,G., III, Lazar,S., Rouviere,P.E., 1995. A new family of peptidyl-prolyl isomerases. Trends Biochem. Sci. 20, 12-14.

Ruffels,J., Griffin,M., Dickenson,J.M., 2004. Activation of ERK1/2, JNK and PKB by hydrogen peroxide in human SH-SY5Y neuroblastoma cells: role of ERK1/2 in $\mathrm{H}(2) \mathrm{O}(2)$-induced cell death. Eur. J. Pharmacol. 483, 163-173.

Ruffett,I., Ayres,J., McBride,D., 1992. Possible chemical pollution. Practitioner 236, 13 16. 
Ruotolo,R., Grassi,F., Percudani,R., Rivetti,C., Martorana,D., Maraini,G., Ottonello,S., 2003. Gene expression profiling in human age-related nuclear cataract. Mol. Vis. $9,538-548$.

Sage,E.H., Bassuk,J.A., Yost,J.C., Folkman,M.J., Lane,T.F., 1995. Inhibition of endothelial cell proliferation by SPARC is mediated through a $\mathrm{Ca}(2+)$-binding EF-hand sequence. J. Cell Biochem. 57, 127-140.

Sambrook J,F.E.M.T. Molecular Cloning: A Laboratory Manual. 2nd ed. Cold Spring Harbor NY. 1989. Cold Spring Harbor Laboratory Press.

Sangan,P., Rajendran,V.M., Geibel,J.P., Binder,H.J., 2002. Cloning and expression of a chloride-dependent Na+-H+ exchanger. J. Biol. Chem. 277, 9668-9675.

Scheier,B., Foletti,A., Stark,G., Aoyama,A., Dobbeling,U., Rusconi,S., Klemenz,R., 1996. Glucocorticoids regulate the expression of the stressprotein alpha Bcrystallin. Mol. Cell Endocrinol. 123, 187-198.

Schmid,F.X., 1993. Prolyl isomerase: enzymatic catalysis of slow protein-folding reactions. Annu. Rev. Biophys. Biomol. Struct. 22, 123-142.

Sheets,N.L., Chauhan,B.K., Wawrousek,E., Hejtmancik,J.F., Cvekl,A., Kantorow,M., 2002. Cataract- and lens-specific upregulation of ARK receptor tyrosine kinase in Emory mouse cataract. Invest Ophthalmol. Vis. Sci. 43, 1870-1875.

Singh,V.K., Moskovitz,J., 2003. Multiple methionine sulfoxide reductase genes in Staphylococcus aureus: expression of activity and roles in tolerance of oxidative stress. Microbiology 149, 2739-2747.

Smith,J.B., Jiang,X., Abraham,E.C., 1997. Identification of hydrogen peroxide oxidation sites of alpha A- and alpha B-crystallins. Free Radic. Res. 26, 103-111.

Sorrells,D.L., Black,D.R., Meschonat,C., Rhoads,R., De Benedetti,A., Gao,M., Williams,B.J., Li,B.D., 1998. Detection of eIF4E gene amplification in breast cancer by competitive PCR. Ann. Surg. Oncol. 5, 232-237.

Spector,A. Aging of the lens and cataract formation. Sekuler, R. Kline D. Dismukes K. Eds. Aging and Human Visual Function . 1982. New York, U.S.A., Alan Liss.

Spector,A., 1984. The search for a solution to senile cataracts. Proctor lecture. Invest Ophthalmol. Vis. Sci. 25, 130-146.

Spector,A., 1995. Oxidative stress-induced cataract: mechanism of action. FASEB J. 9, 1173-1182.

Spector,A., Kuszak,J.R., Ma,W., Wang,R.R., 2001. The effect of aging on glutathione peroxidase-i knockout mice-resistance of the lens to oxidative stress. Exp. Eye Res. 72, 533-545. 
Spector,A., Li,D., Ma,W., Sun,F., Pavlidis,P., 2002. Differential amplification of gene expression in lens cell lines conditioned to survive peroxide stress. Invest Ophthalmol. Vis. Sci. 43, 3251-3264.

Spector,A., Scotto,R., Weissbach,H., Brot,N., 1982. Lens methionine sulfoxide reductase. Biochem. Biophys. Res. Commun. 108, 429-434.

Srinivasan,A.N., Bhat,S.P., 1994. Complete structure and expression of the rat alpha Bcrystallin gene. DNA Cell Biol. 13, 651-661.

St John,G., Brot,N., Ruan,J., Erdjument-Bromage,H., Tempst,P., Weissbach,H., Nathan,C., 2001. Peptide methionine sulfoxide reductase from Escherichia coli and Mycobacterium tuberculosis protects bacteria against oxidative damage from reactive nitrogen intermediates. Proc. Natl. Acad. Sci. U. S. A 98, 9901-9906.

Stark,W.J., Sommer,A., Smith,R.E., 1989. Changing trends in intraocular lens implantation. Arch. Ophthalmol. 107, 1441-1444.

Straatsma,B.R., Horwitz,J., Takemoto,L.J., Lightfoot,D.O., Ding,L.L., 1984. Clinicobiochemical correlations in aging-related human cataract. The Pan American Association and American Journal of Ophthalmology lecture. Am. J. Ophthalmol. 97, 457-469.

Sun,J.K., Iwata,T., Zigler,J.S., Jr., Carper,D.A., 2000. Differential gene expression in male and female rat lenses undergoing cataract induction by transforming growth factor-beta (TGF-beta). Exp. Eye Res. 70, 169-181.

Swaim,M.W., Pizzo,S.V., 1988. Methionine sulfoxide and the oxidative regulation of plasma proteinase inhibitors. J. Leukoc. Biol. 43, 365-379.

Tada-Oikawa,S., Oikawa,S., Kawanishi,M., Yamada,M., Kawanishi,S., 1999. Generation of hydrogen peroxide precedes loss of mitochondrial membrane potential during DNA alkylation-induced apoptosis. FEBS Lett. 442, 65-69.

Tamm,E.R., Russell,P., Johnson,D.H., Piatigorsky,J., 1996. Human and monkey trabecular meshwork accumulate alpha B-crystallin in response to heat shock and oxidative stress. Invest Ophthalmol. Vis. Sci. 37, 2402-2413.

Tseng,S.H., Tang,M.J., 1999. Na,K-ATPase in lens epithelia from patients with senile cataracts. J. Formos. Med. Assoc. 98, 627-632.

Vogt,W., 1995. Oxidation of methionyl residues in proteins: tools, targets, and reversal. Free Radic. Biol. Med. 18, 93-105.

Vougier,S., Mary,J., Friguet,B., 2003. Subcellular localization of methionine sulphoxide reductase A (MsrA): evidence for mitochondrial and cytosolic isoforms in rat liver cells. Biochem. J. 373, 531-537. 
Walther,T.C., Pickersgill,H.S., Cordes,V.C., Goldberg,M.W., Allen,T.D., Mattaj,I.W., Fornerod,M., 2002. The cytoplasmic filaments of the nuclear pore complex are dispensable for selective nuclear protein import. J. Cell Biol. 158, 63-77.

Wan,X.H., Lee,E.H., Koh,H.J., Song,J., Kim,E.K., Kim,C.Y., Lee,J.B., Kim,S.Y., Yao,K., Lee,J.H., 2002. Enhanced expression of transglutaminase 2 in anterior polar cataracts and its induction by TGF-beta in vitro. Br. J. Ophthalmol. 86, 1293-1298.

Weissbach,H., Etienne,F., Hoshi,T., Heinemann,S.H., Lowther,W.T., Matthews,B., St John,G., Nathan,C., Brot,N., 2002. Peptide methionine sulfoxide reductase: structure, mechanism of action, and biological function. Arch. Biochem. Biophys. 397, 172-178.

Welge-Lussen,U., May,C.A., Eichhorn,M., Bloemendal,H., Lutjen-Drecoll,E., 1999. AlphaB-crystallin in the trabecular meshwork is inducible by transforming growth factor-beta. Invest Ophthalmol. Vis. Sci. 40, 2235-2241.

Wilken,N., Senecal,J.L., Scheer,U., Dabauvalle,M.C., 1995. Localization of the Ran-GTP binding protein RanBP2 at the cytoplasmic side of the nuclear pore complex. Eur. J. Cell Biol. 68, 211-219.

Williams,M.R., Duncan,G., Croghan,P.C., Riach,R., Webb,S.F., 1992. pH regulation in tissue-cultured bovine lens epithelial cells. J. Membr. Biol. 129, 179-187.

Wolosin,J.M., Alvarez,L.J., Candia,O.A., 1989. Stimulation of toad lens epithelial $\mathrm{Na}+/ \mathrm{H}+$ exchange activity by hypertonicity. Exp. Eye Res. 48, 855-862.

Wool,I.G., 1996. Extraribosomal functions of ribosomal proteins. Trends Biochem. Sci. 21, 164-165.

Wool,I.G., Chan,Y.L., Gluck,A., 1995. Structure and evolution of mammalian ribosomal proteins. Biochem. Cell Biol. 73, 933-947.

Wu,J., Matunis,M.J., Kraemer,D., Blobel,G., Coutavas,E., 1995. Nup358, a cytoplasmically exposed nucleoporin with peptide repeats, Ran-GTP binding sites, zinc fingers, a cyclophilin A homologous domain, and a leucine-rich region. J. Biol. Chem. 270, 14209-14213.

Wulfkuhle,J.D., Donina,I.E., Stark,N.H., Pope,R.K., Pestonjamasp,K.N., Niswonger,M.L., Luna,E.J., 1999. Domain analysis of supervillin, an F-actin bundling plasma membrane protein with functional nuclear localization signals. J. Cell Sci. 112 ( Pt 13), 2125-2136.

Xing,K.Y., Lou,M.F., 2002. Effect of $\mathrm{H}(2) \mathrm{O}(2)$ on human lens epithelial cells and the possible mechanism for oxidative damage repair by thioltransferase. Exp. Eye Res. 74, 113-122. 
Xue,A.N., Cai,Q.Y., Wang,S.Q., Zhou,A.S., Li,W.X., Fu,P., Chen,X.S., 1996. Antioxidant status in persons with and without senile lens changes. Biomed. Environ. Sci. 9, 144-148.

Yang,Y., Sharma,R., Cheng,J.Z., Saini,M.K., Ansari,N.H., Andley,U.P., Awasthi,S., Awasthi,Y.C., 2002. Protection of HLE B-3 cells against hydrogen peroxide- and naphthalene-induced lipid peroxidation and apoptosis by transfection with hGSTA1 and hGSTA2. Invest Ophthalmol. Vis. Sci. 43, 434-445.

Yermolaieva,O., Xu,R., Schinstock,C., Brot,N., Weissbach,H., Heinemann,S.H., Hoshi,T., 2004. Methionine sulfoxide reductase A protects neuronal cells against brief hypoxia/reoxygenation. Proc. Natl. Acad. Sci. U. S. A 101, 1159-1164.

Yokoyama,N., Hayashi,N., Seki,T., Pante,N., Ohba,T., Nishii,K., Kuma,K., Hayashida,T., Miyata,T., Aebi,U., ., 1995. A giant nucleopore protein that binds Ran/TC4. Nature 376, 184-188.

Young,R.W. Age-related cataract. Oxford University Press, Oxford.

Zhang,W., Hawse,J., Huang,Q., Sheets,N., Miller,K.M., Horwitz,J., Kantorow,M., 2002. Decreased expression of ribosomal proteins in human age-related cataract. Invest Ophthalmol. Vis. Sci. 43, 198-204.

Zigler,J.S., Jr., Huang,Q.L., Du,X.Y., 1989. Oxidative modification of lens crystallins by H2O2 and chelated iron. Free Radic. Biol. Med. 7, 499-505. 